UNIVERSIDADE DE SÃO PAULO

FACULDADE DE FILOSOFIA, LETRAS E CIÊNCIAS HUMANAS

DEPARTAMENTO DE GEOGRAFIA

PROGRAMA DE PÓS-GRADUAÇÃO EM GEOGRAFIA HUMANA

EDUARDO DONIZETI GIROTTO

Escola, Lugar e Poder: as aventuras de um professorpesquisador entre o subúrbio e a periferia. 
UNIVERSIDADE DE SÃO PAULO

FACULDADE DE FILOSOFIA, LETRAS E CIÊNCIAS HUMANAS

DEPARTAMENTO DE GEOGRAFIA

PROGRAMA DE PÓS-GRADUAÇÃO EM GEOGRAFIA HUMANA

\title{
Escola, Lugar e Poder: as aventuras de um professor- pesquisador entre o subúrbio e a periferia.
}

\section{Eduardo Donizeti Girotto}

\begin{abstract}
Dissertação apresentada ao Programa de Pós-Graduação em Geografia Humana do Departamento de Geografia da Faculdade de Filosofia, Letras e Ciências Humanas da Universidade de São Paulo para a obtenção do título de Mestre em Geografia Humana.
\end{abstract}

Orientadora: Profa. Dra. Glória da Anunciação Alves

São Paulo

2009 


\section{Resumo}

O presente trabalho tem como objetivo compreender as diferentes formas que assumem as relações entre escola, lugar e poder no subúrbio e na periferia paulista. Para tanto, foram estudadas duas escolas situadas na região metropolitana de São Paulo (uma em São Caetano do Sul, a outra no Bairro de Itaquera, Zona Leste de São Paulo), buscando descrever de que maneira as problemáticas acerca do lugar interferem nas relações educativas que ocorrem no interior destas unidades escolares e como tais relações, por sua vez, são perpassadas por questões relacionadas ao poder em suas diferentes escalas geográficas de realização. Para além de uma visão generalizante acerca da escola e da educação, o que buscamos com este trabalho é empiricizar a escola, desvendando os elementos e as problemáticas que envolvem escolas reais, situadas, localizadas e contextualizadas. Para além de uma visão de fora, localizada apenas na academia, nosso olhar está situado no interior das próprias relações que buscamos desvendar visto que não abdicamos de nossa ação docente como professor da educação básica para realizar tal pesquisa. Ao contrário, é exatamente esta escolha de fazê-la no interior das próprias contradições que permeiam as relações entre escola, lugar e poder que constitui, em nossa perspectiva, o grande desafio desta dissertação. Esperamos, sinceramente, que a partir daquilo que por ora apresentamos, possamos ter enfrentado, pelo menos em parte, tal desafio, contribuindo assim para o diálogo com outras pesquisas que tenham no desvendamento das problemáticas que envolvem as relações entre escola, lugar e poder seu principal objetivo. 


\section{Abstract}

The present work has as objective understands the different forms that takes over the relationship among school, community's place and power in the paulistan suburbs and outskirts. For this were studied two schools placed in metropolitan region of São Paulo (one in São Caetano do Sul, other in Itaquera district, east zone of São Paulo.), looking for describing in what way the problems about the place interfere in educational relations that occurring inside of these scholar unities and how these relation can be interlaced by questions linked to the power in its different geographic scales of realization. Beyond for a generally view about school and education, we search with this work is bringing to reality the school, bringing to the light the elements and problematic that involve real school, placed, localized and in a context. Forward an outside context vision that is only inside the University, our glance is placing in the our own relation that we search to discover, accepted we haven't abdicated of our teacher action as educator to make this research. On the contrary it is exactly the chose of doing it inside own contradictions that round the relation among school, place and power that constitutes, in our perspective, the big challenge of this dissertation. We sincerely hope from that we presented for the time being presented, we can facing, at least in parts, such challenge, contributing in this way for the dialogue with other researches that have at the resolution of problematic that involve the relations among school, community's place and power its main objective. 


\section{Agradecimentos}

A cada nova etapa concluída nos caminhos que percorremos em nossas vidas faz necessário um olhar para trás, um momento de reflexão e de sincero agradecimento a todos que, em momentos diferentes, nos ajudaram nesta travessia.

Em primeiro lugar, gostaria de agradecer a $\operatorname{Prof}^{a} \operatorname{Dr}^{a}$ Glória da Anunciação Alves que aceitou novamente me orientar. De maneira lúcida, apontou-me os limites e as possibilidades daquilo que buscava compreender; questionou-me, sem porém dar respostas, apontando caminhos que poderia percorrer. Fez do exercício da crítica um importante momento de aprendizagem em minha tão curta carreira acadêmica. Agradeço-lhe pela sinceridade, pela disposição e por me permitir construir os erros e acertos que hoje apresento no interior desta dissertação.

Aos Professores Doutores Élvio Rodrigues Martins e José Sérgio Carvalho da Fonseca pela participação em momentos decisivos desta dissertação. Ao convidá-los para a banca de qualificação e de defesa sabia que poderia contar com suas críticas contundentes, com os rigores metodológicos e com uma paixão acima do normal sobre o conhecimento e a vontade de ensinar. Assim como na graduação foram fundamentais para a construção das bases para o meu desenvolvimento acadêmico, marcarão para sempre esta outra etapa da minha vida acadêmica na qual descobri que não se pode fazer pesquisa sem se acreditar naquilo que se escreve e se faz.

Ao Aldo, Fabiano, Paulo, Rafa, David, Juliana, Ana Paula, Renato, Wesley, Thelma, Lu e tantos outros amigos e companheiros de profissão que me brindaram com a partilha constante de acreditar na possibilidade da educação. A todos estes que, diariamente, em diversas salas de aulas nas periferias e subúrbios deste país acreditam nas palavras de Paulo Freire: "se a educação sozinha não transforma a sociedade, sem ela tampouco a sociedade muda"

Aos meus alunos da EME Prof a Alcina Dantas Feijão e da EMEF Dep. Flores da Cunha agradeço-lhe pelos questionamentos, pela indisciplina, pela nãoaceitação. Agradeço-lhes por me ensinarem sobre a escola real, aquela que durante muito tempo, abismado que estava com a escola ideal dos livros e manuais de pedagogia, teimava em não enxergar. Agradeço-lhes pelos momentos 
de desespero, de desanimo, de alegria, e de realização que marcam o cotidiano de um professor. Sem esta consciência de sentir-me vivo, desperto diariamente por questões tão amplas ou por olhares e abraços, não conseguiria realizar aquilo que hoje aqui apresento.

A minha família, por respeitar os caminhos que decidi percorrer e por acreditarem na paixão que tenho naquilo que faço.

A Alice, que acaba de vir ao mundo e por isso me ajuda a entender porque precisamos continuar.

A Pri, pelo colo, afago e presença naqueles momentos onde o peso do mundo já não é possível suportar sozinho.

Por fim, agradeço a Paulo Freire, Hannah Arendt, Sartre e tantos outros que me ensinaram o valor da responsabilidade de nossas lutas cotidianas. 


\section{Sumário}

Introdução.

1. A relação escola-lugar e suas implicações.

2. A escola no subúrbio: o caso da EME Profa Alcina Dantas Feijão.

2.10 desvendamento do lugar

2.2 Do silêncio ao desvelamento

3. Entre o poder e o nada: a escola na periferia 102

3.1 Espaço e escola na periferia paulista.

3.2 O olhar de dentro: a praça e a escola na perspectivas dos sujeitos da educação. 126

3.3 Retomando algumas idéias: da crise do trabalho docente a crise da sociedade do trabalho.

3.4 Quando os alunos descobrem a escola: entrevista com alunos da EE Profa. Ruth Cabral Troncarelli.

Considerações finais.

Posfácio.

Bibliografia. 
"De modo geral, o educador é um super-homem: dele tudo se espera, tudo se exige; a ele cabe uma responsabilidade sem limites. Em suas mãos, estão a felicidade de cada um e de todos os alunos (sedentos de saber...), o futuro da pátria, - bem-estar da sociedade (tão conturbada de nossos dias...), os destinos do mundo (cada vez mais invadido pela tecnologia...) o progresso da humanidade. Tudo depende, quase exclusivamente, do educador: o sucesso ou fracasso do aluno, da comunidade, da Pátria, da Humanidade". Guido de Almeida.

São seis e meia da manhã. Atravesso solitário o pátio que leva a sala dos professores. Tudo parece calmo. O silêncio me permite ouvir os sons dos meus passos. Atravesso tranquilamente 0 pátio. As cores claras da parede contribuem para acentuar a leve sensação de calma.

Aos poucos vou adentrando a escola.

Sou professor há pouco tempo. No SESI A. E. Carvalho estou há apenas três meses. Tive outras experiências docentes, mas talvez apenas agora comecei a assumir esta profissão.

Leciono Geografia. Ensino caminhos que ainda não caminhei, mundos que aos poucos vou descobrindo. Descrevo lugares que, aos pedaços, continuam dentro de mim. Talvez por ser geógrafo também o espaço-escola me seja tão importante. Observo-o atentamente. Descrevo-o e procuro compreendê-lo: paredes de cor verde, um pátio longo, uma escadaria central, dois andares, portas fechadas, portas abertas, uma biblioteca, um refeitório com mesas e cadeiras redondas de cor vermelha, janelas de vidro, dois vidros quebrados, um pequeno jardim, um pátio externo, uma cozinha, um escondido banheiro dos professores, a sala da coordenação, a sala da supervisão, a secretaria, a sala dos professores... Chego enfim a sala dos professores. Uma mesa longa colocada no centro, coberta por uma toalha de plástico. Em um canto, janelas que não dão para lugar nenhum. No outro, armários de ferro, alguns trancados com cadeados, outros totalmente abertos. No fundo, há uma outra sala, pequena, na qual são depositados os materiais de trabalho dos professores: diários, livros, aventais, réguas, burocracias. Em um outro canto, uma lousa repleta de avisos: calendários, uso das salas, entrega de relatórios, entrega de planos docentes, recados para elevar a autoestima. 
Sento-me sempre numa cadeira diferente. Aos poucos vou me apossando da sala. Um copo d água é essencial para espantar o sono. Sento-me mais uma vez. Retiro o material da mala: transparências, textos, livros, vídeos. Tento organizá-los sobre a mesa. Em vão. Guardo a mala no armário protegido por um cadeado destrancado. Não tenho a chave. Volto a me sentar. Aos poucos, os outros professores vão chegando. Chegam sempre na mesma ordem. Todos os dias.

É interessante notar como nós professores criamos um ritmo próprio em nossas vidas. Agimos como se tivéssemos um relógio no peito marcando os nossos passos.

Os professores parecem estar sempre de passagem pela sala. Dificilmente permanecem. Caminham sempre apressados na direção de algum lugar: a casa, outra escola. Vivem o ritmo de quem passa, a eterna travessia que não nos permite aprofundarmos sobre o lugar, experenciá-lo, vivê-lo em suas múltiplas possibilidades, nos conflitos que aparecem sem hora marcada, ocasionalmente nas idéias que explodem nos encontros sem prévio aviso, das idéias que nascem no momento do desespero, da falta de sentido, do absurdo de sentir-se só ao lado de tanta gente.

A sala dos professores revela, portanto, o ritmo próprio dos professores, o ritmo da constante passagem, da repetição destruidora que parece nos colocar sempre no mesmo lugar. Sentimo-nos cansados porque parecemos estar sempre no mesmo ponto".

O relato que descrevemos acima é resultado da observação de um dia comum de trabalho na unidade do SESI A. E. Carvalho, zona leste de São Paulo. Trata-se de uma descrição primeira, feita sem muito rigor e que buscava, naquele momento, trazer a tona algumas impressões e sentimentos sobre aquele lugar.

Foi nesta unidade escolar que iniciei minhas ações como professor. Havia acabado de sair da Universidade. Idéias fervilhavam em minha cabeça, junto a uma sensação de medo e de insegurança. Conhecia a escola da teoria, aquela dos livros e dos discursos, com alunos e professores perfeitos e dotada de excelentes condições de trabalho. O que ocorria, porém, pela primeira vez, após sair da universidade, é que me deparava com uma escola real. E, sinceramente, não sabia como começar.

Esta sensação de incomodo que surgiu a partir deste primeiro momento me levou a uma série de indagações. O que de fato é uma escola? Será possível falar realmente de um sistema escolar, de uma rede de ensino, visto as diferenças 
encontradas em cada uma das unidades escolares? Para mim, em uma primeira impressão, havia um descompasso entre o discurso reproduzido na universidade e as práticas encontradas ocorridas nas escolas de educação básica. Muitos destes discursos partiam de um pressuposto, em nossa perspectiva, equivocado: consideravam a escola como uma realidade generalizável, descontextualizada. Falava-se de escola, sem se pensar em sua pluralidade, suas características específicas.

Foi a partir destas inquietações e das vivências na educação básica que o projeto desta dissertação de mestrado começou a ser construído. O incomodo me levou a ação e a ação, por sua vez, me fez adentrar a escola. Como objetivo central desta dissertação, portanto, buscaremos analisar a escola a partir da relação que ela estabelece com o lugar, analisando assim os conflitos, os limites e as possibilidades das práticas sócio-espaciais que nascem desta relação e que podem, também, serem compreendidas a partir dela. Nosso intuito, neste sentido, é desvendar escolas reais no interior do movimento do discurso que afirma a escola como elemento generalizável.

O que nos preocupa, desta maneira, nesta pesquisa e que a direcionará é a problemática do desvendamento da escola real, de suas contradições, das possibilidades e das interferências que surgem a partir das relações que estabelece com o contexto e a situação do qual é um dos elementos determinantes. Para além de uma leitura generalizante, que busque em uma análise superficial a compreensão dos problemas atuais que envolvem a educação, nos propomos analisar as particularidades e singularidades de escolas reais, de suas geografias específicas, da empiricização de suas reais possibilidades. Para tanto, valemo-nos da afirmação do Professor Milton Santos, para o qual

O mundo, como um conjunto de essências e de possibilidades, não existe para ele próprio, e apenas o faz para os outros. É o espaço, isto é, os lugares, que realizam e revelam o mundo, tornando-o historicizado e geograficizado, isto é, empiricizado (SANTOS, 2003: 112).

Neste sentido, o desafio central deste trabalho é empiricizar a escola, geografizá-la, torná-la real e singular sem, porém, correr o risco de perder a 
capacidade de relacioná-la as lógicas mais amplas da qual também é resultado. Em nossa perspectiva, esta empiricização da escola se faz necessário no sentido em que, na atualidade, difundem-se discursos generalizantes acerca da realidade escolar. Tais discursos, por sua vez, ocultam a diversidade de sujeitos e trajetórias que as escolas públicas brasileiras possuem, muitas delas marcadas pela reconstrução cotidiana, pela tentativa de transformação por meio de práticas muitas vezes não reconhecidas no interior das análises sobre a escola. Uma perspectiva que se quer geográfica deve também possibilitar o reconhecimento das singularidades e particularidades que marcam a configuração de uma certa espaço-temporalidade. Para além de uma visão geográfica que associa a universalidade a uma certa homogeneidade, partimos do conceito de espacialidade enquanto "a coexistência simultânea de outros", conforme nos aponta MASSEY (2008:31). Segundo a autora, este conceito de espacialidade visa romper com uma concepção do espaço como fechado, resultado do processo de modernização, no qual as estruturas de desenvolvimento e de progresso já estão pré-definidas.

O espaço jamais poderá ser essa simultaneidade completa na qual todas as interconexões já tenha sido estabelecidas e no qual todos os lugares já estão ligados a todos os outros. Um espaço, então, que não é nem recipiente para identidades sempre-já constituídas nem um holismo completamente fechado. É um espaço de resultados imprevisíveis e de ligações ausentes. Para que o futuro seja aberto, o espaço também deve sê-lo. (MASSEY, 2008:32).

É este caráter imprevisível, não-controlável, não pré-definido das relações sócio-espaciais que se desenvolvem a partir das escolas estudadas que procuraremos trazer a tona e analisar no decorrer desta pesquisa. Cabe-nos, portanto, desvendar escolas que estão em construção porque as próprias condições sócio-espaciais e os sujeitos que a elas recriam também assim o estão. Escolas que se fazem dinâmicas, contraditórias, ora em subordinação ao sistema vigente, ora em extremo desagravo, que acentuam a ação de seus sujeitos como elementos centrais de sua própria realização.

Para a realização de tal tarefa nos propomos analisar duas escolas 
públicas, situadas em regiões diferentes da Grande São Paulo. Trata-se, de um lado, da EME Profa Alcina Dantas Feijão, localizado no bairro Mauá, no município de São Caetano do Sul, e do outro da Escola Estadual Profa Ruth Cabral Troncarelli, situada no Conjunto Habitacional José Bonifácio (COHAB II e III), na zona Leste do município de São Paulo. A escolha de tais unidades ocorreu por uma série de motivos que explicitaremos nos capítulos posteriores. Vale ressaltar, porém, que a proximidade com tais unidades escolares decorrentes de motivos pessoais e profissionais foram elementos fundamentais para a escolha das mesmas, visto que nos propomos fazer uma análise detalhada e próxima de tais realidades.

Para o desenvolvimento de nossa pesquisa, utilizamo-nos de uma série de conceitos. Tais conceitos, porém, não surgiram aprioristicamente. O desenvolvimento da pesquisa e dos trabalhos de campo nos trouxe a necessidade de compreensão da realidade estudada por meio de tais conceitos. $A$ cada passo dado em direção ao interior da escola e do seu contexto, situações e problemáticas que ainda, de fato, não havíamos enfrentado, surgiam. Neste sentido, os conceitos de subúrbio, periferia, cultura escolar foram fundamentais na análise destas problemáticas enfrentadas no decorrer da pesquisa e que, em nossa perspectiva, nos permitiram ampliar as discussões aqui realizadas.

Tínhamos, de início, uma categoria que considerávamos essencial para a análise das escolas em questão, que seja, a categoria Lugar. Em certa medida, partíamos do pressuposto que a escolha desta categoria como mediadora de nossa relação com os objetos de estudos escolhidos nos possibilitasse uma olhar mais empírico e detalhado sobre os processos, as dinâmicas e os fenômenos que permeavam as relações sócio-espaciais em cada uma das escolas estudadas. $A$ escolha de tal categoria revelava também uma questão de base, que seja, a nossa inserção no interior da ciência geográfica. O que buscamos nesta dissertação é uma interpretação geográfica das escolas estudadas e por este motivo a escolha de muitas categorias que nesta dissertação serão desenvolvidas remete também a esta questão.

A questão da relação escola-lugar nos levou a dois conceitos fundamentais, que seja, os conceitos de periferia e de subúrbio. Ao adentrar as escolas estudadas, deparamo-nos com dinâmicas específicas que remetiam aos próprios processos que estruturaram o lugar no interior de uma dinâmica mais 
ampla, que seja, os diferentes momentos de reprodução de modo de produção capitalista em elemento espacial. Neste sentido, para que pudéssemos compreender as dinâmicas presentes em cada uma das escolas, era fundamental uma clareza das principais diferenças entre os conceitos de subúrbio e periferia, relacionando aos processos e dinâmicas do próprios do desenvolvimento do modo de produção capitalista no mundo. A partir disso, passamos a qualificar, com base nestes conceitos, os lugares os quais estávamos analisando, percebendo assim que as dinâmicas sócio-espaciais que ocorriam no interior das escolas estudadas eram também decorrentes de dinâmicas externas específicas do subúrbio e da periferia.

A perspectiva de análise a partir dos conceitos de subúrbio e de periferia permitiu que nos aprofundássemos nas questões que envolviam a relação entre escola e lugar. A partir disso, percebemos que as relações sócio-espaciais ali existentes eram marcadas também por relações de poder, intimamente ligadas a dinâmicas específicas de cada uma das localidades. Tais dinâmicas, no entanto, não se findavam apenas na escala local; possuíam ramificações nas diferentes escalas geográficas de reprodução da vida. Neste sentido, para que pudéssemos compreender de que maneiras a relação entre escola e lugar se realizava era fundamental um melhor entendimento de como se configuravam as relações de poder que permeava tal relação, bem como suas implicações em diferentes escalas geográficas.

Para tanto, desenvolvemos o conceito de geopolítica escolar. Durante muito tempo, o termo geopolítica esteve apenas ligado aos conflitos envolvendo Estados. Este fato ocorria, em parte, porque as principais teorias que embasavam a geografia política e a geopolítica tradicionais defendiam que seriam os Estados os únicos sujeitos geopolíticos, responsáveis pelas dinâmicas territoriais existentes e, portanto, os únicos merecedores de qualquer atenção por parte desta ciência.

Esta concepção do Estado enquanto único agente de poder resulta numa geografia política alicerçada em conceitos e categorias que remetem sempre a esta figura central. Neste sentido, a geografia política proposta por Ratzel se sustenta a partir da seguinte base teórica: população, território e soberania. Estes três conceitos seriam, portanto, os elementos fundamentais para se compreender o poder do Estado em sua configuração sócio-espacial. 
Esta base teórica da Geografia política, que tem suas raízes na obra de Ratzel, será o ponto de encontro entre a Geografia Política e a Geopolítica, no sentido em que as duas ciências partem do mesmo pressuposto, que seja, a concepção do Estado enquanto único agente do poder. Nascidas no contexto que antecede as duas Guerras Mundiais, a Geografia Política e a Geopolítica tradicionais se tornam objetos de estratégias dos diferentes Estados-Nacionais que se conflitam em busca da hegemonia mundial, com o aumento de suas áreas de domínio e influência. Esta incorporação das duas ciências pelo establishment estatal resultará, por parte dos outros ramos da geografia, em um certo desprezo e numa invalidação de seus pressupostos teórico-metodólogicos, acusadas que são, tais disciplinas e seus defensores, de atuarem em prol de interesses que vão além do campo científico.

Nas últimas décadas, porém, houve uma mudança de perspectiva na análise espaço-temporal do poder ${ }^{1}$. Tal mudança está relacionada às próprias transformações que as estruturas de poder sofreram e vem sofrendo após a segunda guerra mundial. O que temos visto, nas últimas décadas, é uma crise que envolve a tradicional organização centralizada e autoritária do Estado Nacional e o surgimento de novos focos de poder, relacionados ao próprio desenvolvimento desigual e combinado do modo de produção capitalista. A atuação de órgãos em escala global, mesmo que controlados localmente, como a ONU, o FMI, o Banco Mundial, as empresas transnacionais, os movimentos sociais, surge como novo elemento a ser analisado geopoliticamente, pois revela os novos focos e as novas dinâmicas territoriais do poder na fase atual do modo de produção capitalista. O reconhecimento destes novos agentes espaçostemporais do poder requer, portanto, uma outra abordagem teórico-metodológica da análise geopolítica.

\footnotetext{
O dicionário Oxford de Filosofia define poder da seguinte maneira: "O poder de um indivíduo ou instituição é a capacidade de este conseguir algo, quer seja por direito, por controle ou por influência. $\mathrm{O}$ poder é a capacidade de se mobilizar forças econômicas, sociais ou políticas para obter um certo resultado, e pode ser medido pela probabilidade de esse resultado ser obtido em face dos diversos tipos de obstáculos ou oposição enfrentados. Não é essencial a sua definição que o resultado seja conscientemente procurado pelo agente: o poder pode ser exercido na ignorância de sua existência ou efeitos, embora, claro, seja frequentemente exercido de forma deliberada". BLACKBURN, 1994: 301. A capacidade de influencia, de determinação, de controle exercido por um grupo em detrimento de outros torna-se, portanto, a partir desta definição, a característica determinante do poder. Cabe, porém, uma discussão mais ampla, que realizaremos a seguir, sobre as formas como este poder é exercido, bem como quais são os seus principais agentes na atualidade. Vale ressaltar, porém, que em nossa perspectiva, o termo poder não possui caráter pejorativo. Todas as relações sociais são também mediadas pelo poder e é da discussão acerca do mesmo que se fundamenta a política.
} 
Obras como "Microfísica do Poder" de Michel Focault, "O Poder Simbólico" de Pierre Bourdieu, "A geografia, isso serve, em primeiro lugar, para fazer a guerra" de Yves Lacoste e "Por uma geografia do poder" de Claude Raffestin, já citada anteriormente, foram fundamentais para esta transformação teóricometodológica pela qual passaram a geopolítica e a geografia política nos últimos cinquenta anos no mundo e no Brasil. Tais obras são essenciais porque invertem a lógica de pensar o poder em sua dimensão espacial apenas do ponto de vista do Estado Nacional, surgido das revoluções burguesas do século XVIII, ampliando a discussão e levando em consideração os outros sujeitos do poder, suas escalas de atuação, suas formas espaços-temporais. Nestas obras, o poder é pensando em suas mais diferentes escalas, em suas diversas manifestações, o que permite um olhar mais atento a outras formas de poder que sempre receberam pouca ou nenhuma atenção das grandes correntes clássicas do pensamento geopolítico.

Segundo FOUCAULT, a lógica do poder sofreu uma importante mudança a partir do século XIX. Segundo o autor, o poder associado ao Estado Moderno Europeu era o poder relacionado ao causar a morte ou deixar viver. Segundo o autor,

O poder era, antes de tudo, nesse tipo de sociedade, direito de apreensão das coisas, do tempo, dos corpos e, finalmente, da vida; culminava-se com o privilégio de se apoderar da vida para suprimi-la (FOUCAULT, 2007:148)

O poder do Estado Moderno dizia respeito a capacidade e autoridade que $\circ$ mesmo tinha sobre a definição da vida daqueles que subordinava. Esta definição se dava no envio do exército à guerra, na morte daqueles que se rebelavam contra o poder constituído, na autoridade de exercer, de todas as maneiras possíveis, o direito sobre a cessão da vida, ou seja, a produção da morte. Porém, a partir do século XIX, este poder sobre a morte torna-se mais claramente um poder sobre a produção da vida. Para além de fazer morrer, o que temos é um poder exercido no sentido de se fazer viver.

Agora é sobre a vida e ao longo de todo o seu desenrolar que o poder estabelece seus pontos de fixação; a morte é o limite, o momento que Ihe escapa; ela se torna o ponto mais 
secreto da existência, o mais 'privado'. (FOUCAULT, 2007:151)

Dessa maneira, esta transformação mundial das relações de poder com a emergência e o reconhecimento de novos e antigos poderes nos permitiu perceber que tais relações, em suas diferentes escalas e formas de manifestação, estão presentes na atualidade como elementos que definem e redefinem as relações sociais no modo de produção de capitalista. Para tanto, partimos do pressuposto de que vivemos em uma sociedade fragmentada, na qual hierarquias são construídas e destruídas a todo o momento. Cada hierarquia construída pressupõe uma forma e um conteúdo sócio-espacial que é causa e consequência das relações de poder ali estabelecidas, mediadas pela mercadoria, formaconteúdo fundamental para o desenvolvimento do modo de produção capitalista. Reconhecer as estratégias espaciais relacionadas à manutenção ou a destruição de hierarquias de poder estabelecidas nos permite entender de que maneira tais relações se contrapõem ou reproduzem as relações de poder existentes e necessárias à reprodução ampliada do modo de produção capitalista.

Por que, então, analisar as relações de poder na escola, se as mesmas estão presentes em todo lugar?

A escolha da escola como lócus de nossa análise parte do pressuposto de que na escola as forças antagônicas de manutenção e transformação do status quo relacionado à reprodução ampliada do modo de produção capitalista, estejam mais explicitas, mesmo que compreendidas e interpretadas pelos seus diferentes sujeitos de maneiras diferentes.

A escola, como aparelho de reprodução do Estado (retomando a idéia já um pouco esquecida de Louis Althusser) procura reproduzir a sociedade que the deu origem. A escola atual, bem como a sociedade que the deu origem, são também, em sua forma e organização, resultado do desenvolvimento desigual e combinado do modo de produção capitalista. É, portanto, este desenvolvimento desigual e combinado que esta escola pretende reproduzir. E reproduz. Basta olharmos para o sistema educacional brasileiro e verificaremos que ele é um reflexo das desigualdades e dos contrastes existentes em todo o país. Desigualdade que é ao mesmo tempo mundial, nacional, regional e local. 
Desigualdade que é a base e o fundamento do desenvolvimento do modo de produção capitalista.

Neste sentido, a escola, ao reproduzir as contradições inerentes ao modo de produção capitalista expõe suas próprias contradições e sua própria fraqueza. Como reproduzir um sistema inerentemente autodestrutivo, social e ambientalmente? Não é apenas a escola que está em crise, mas toda a sociedade.

A escola é, portanto, o campo de força das relações de poder que extrapolam os seus limites, mas que nela se realizam. Para tanto, é preciso desconstruir uma certa visão romântica da escola, decorrente de muitas leituras feita da mesma pelos teóricos da escola nova, que a concebem como lugar apenas do diálogo não conflituoso e da harmonia. Sem desconsiderar tais elementos é preciso, porém, compreender a escola também como lugar do conflito, da violência, da discórdia, das relações de poder em seus mais diferentes níveis, para que assim se possa desvendar os motivos que levam a escola a não cumprir a sua principal função, que seja, a de ensinar.

Neste sentido, ao utilizarmos o termo geopolítica escolar nesta pesquisa objetivamos retomar a discussão acerca do caráter conflituoso da escola, vendo nele um dos principais elementos definidores da escola na atualidade. A utilização da expressão geopolítica se justifica a partir do pressuposto de que compreendemos as relações entre os sujeitos escolares como, ao mesmo tempo, intencionais e não intencionais. Um aluno que se nega a fazer uma determinada atividade pode assim agir por não ver significado na atividade ou para desafiar a autoridade escolar presentificada na figura do professor, fortalecendo assim sua imagem frente aos outros membros do grupo de alunos. Um professor, por sua vez, pode se negar a produzir um plano de aula por despreparo ou talvez porque veja no enfrentamento da instituição escolar uma das maneiras de questionar a forma como a mesma está estruturada. Não se pode, portanto, fazer generalizações abstratas em educação, descoladas da realidade, calcadas mais em pontos de vistas do que em pesquisas de campo e observações participantes. A escolha de duas determinadas realidades, o subúrbio e a periferia, somadas a realização de trabalhos de campo, neste caso, são caminhos fundamentais para se compreender as intencionalidades e não-intencionalidades que se revelam nas relações cotidianas entre os diversos sujeitos escolares. 
Além disso, outro elemento fundamental que pudemos desenvolver no decorrer desta pesquisa foi a compreensão da existência de elementos particulares que dizem respeito a dinâmicas específicas ocorridas no interior de cada uma das escolas estudadas. Cada uma destas dinâmicas surgia, em certa medida, das relações sócio-espaciais ali estabelecidas e resultavam em elementos fundamentais para sua compreensão. Desta verificação da existência de dinâmica específicas em cada uma das escolas estudadas, que surgiu a necessidade de buscarmos um conceito capaz de nos permitir elaborar uma certa compreensão de tais elementos. Neste sentido, passamos a utilizar o conceito de cultura escolar como mediador da relação entre pesquisador e objetos de pesquisa, sempre ressaltando ser difícil realizar uma divisão rígida entre estes dois elementos.

Em texto, o pesquisador francês Dominique Julia apresenta o conceito de cultura escolar.

\begin{abstract}
Para ser breve, poder-se-ia descrever a cultura escolar como um conjunto de normas que definem conhecimentos a ensinar e condutas a inculcar, e um conjunto de práticas que permitem a transmissão desses conhecimentos e a incorporação desses comportamentos; normas e práticas coordenadas a finalidades que podem variar segundo as épocas (finalidades religiosas, sociopolíticas ou simplesmente de socialização). (JULIA, 2001:10).
\end{abstract}

Neste sentido, a cultura escolar surge como uma das esferas de análise das sociedades que tem na escola importante ponto de referência. Para Julia, a cultura escolar se constitui enquanto arcabouço de normas e práticas que definem a instituição escolar enquanto instituição dinâmica, em processo constante de transformação. De certo modo, a escola, enquanto instituição, é portadora de uma determinada cultura, que se deixa revelar na análise das práticas sócio-espaciais que ali ocorrem diariamente. Para além de uma visão generalizante que pensa escola e alunos ideais, descolados do contexto e da situação do qual fazem parte, a análise da escola a partir da cultura escolar permite tornar concreto os conflitos, as possibilidades que permeiam as escolas e os seus diferentes sujeitos espaciais, possibilitando assim a análise de uma escola em processo e não dada a priori, bem como daquilo que revela e daquilo que oculta.

A cultura escolar é resultado da relação complexa e dinâmica entre escola 
e sociedade, sendo que é fundamental que tanto a escola quanto a sociedade que são elementos constituintes desta relação dialógica sejam contextualizados e situados. Não se poder falar de uma cultura escolar em geral, assim como não se pode falar de uma sociedade em geral, de uma escola em geral. No nosso caso, a cultura escolar será analisada a partir de um diálogo profícuo com os conceitos de subúrbio e periferia, visto que aquilo que ocorre fora da escola interfere diretamente em seu interior, sendo o inverso também verdadeiro.

Como veremos mais adiante, a utilização do conceito de cultura escolar foi fundamental para que pudéssemos explicitar os elementos específicos das relações sócio-espaciais existentes em cada uma das escolas estudadas, sendo assim essencial para o desenvolvimento do objetivo ao qual nos propomos nesta pesquisa, que seja, o de empiricizar a escola a partir da relação que estabelece com o lugar.

Outro elemento fundamental para o entendimento desta dissertação diz respeito as escolhas metodológicas por nos realizadas no decorrer da pesquisa. Tais escolhas revelam, por sua vez, uma questão específica que diz respeito ao lugar de onde decidimos falar no interior desta dissertação, que seja, o do professor de Educação Básica. Todo o processo de pesquisa que envolve esta dissertação foi realizado sem que nos desvinculássemos de nossas atividades docentes na EME Profa Alcina Dantas Feijão. Esta especificidade nos levou a optar por uma metodologia capaz de revelar ao leitor este nosso lugar no interior da pesquisa. Para tanto, adotamos os fundamentos da etnografia e da teoria da implicação como essenciais para a realização desta pesquisa. Esta dupla abordagem metodológica se justifica também pelo fato de não objetivarmos desenvolver um trabalho comparativo. Nosso intuito é antes descrever os elementos, processos e dinâmicas que configuraram cada uma das escolas estudadas, levando em consideração que as relações que possuo com cada uma das escolas são bens diferentes. Enquanto leciono na EME Profa Alcina Dantas Feijão, minha relação com EE Profa Ruth Cabral Troncarelli é de maior distanciamento.

Neste sentido, ao desenvolver as pesquisa na escola na qual leciono optei pela teoria da implicação. Em texto publicado no Boletim Paulista de Geografia, $n^{\circ}$ 84, Ricardo Baitz discute as questões relativas ao trabalho de campo em geografia e aponta as principais contribuições que a teoria da implicação pode 
fornecer. Segundo o autor, a implicação, enquanto metodologia de pesquisa, apresenta uma crítica ao fazer científico tradicional pautado na divisão entre pesquisador e objeto de pesquisa. Segundo o autor, analisando a visão tradicional de ciência,

Aproximar-se demais do objeto, tornar-se parte dele, deixarse invadir pela pesquisa são posições condenáveis ou impeditivas pelo método científico tradicional (BAITZ, 2006: 27).

Para os adeptos da ciência tradicional, fazer ciência significa seguir uma série de regras, normas e procedimentos que possibilitam ao saber científico a tão aclamada objetividade. Porém, esta visão de ciência oculta uma idéia implícita e que sustenta um dos elementos de desigualdade da sociedade, que seja, a de que a ciência é privilégio de alguns. Pensar a ciência de outra maneira que não a tradicional,

Significaria a admissão que o homem comum, despreparado das refinadas técnicas de investigação científica, pode também pensar, o que acabaria com a prerrogativa dos cientistas (BAITZ, 2006: 28).

De modo geral, a teoria da implicação teve seu desenvolvimento ligado as pesquisas antropológicas e de caráter etnográfico realizadas no final do século XIX e início do XX, estando relacionada a importantes nomes da antropologia como B. Malinowski e C. Geertz ${ }^{2}$. Tal teoria parte do princípio de que para se compreender uma determinada época, uma determinada espaço-temporalidade, faz-se necessário que nela estejamos implicados e estar implicado é vivê-la em todas as suas contradições. É incorporar, interiorizar a espaço-temporalidade que se quer conhecer.

Esta teoria teve papel fundamental para se romper com a maneira de se fazer pesquisa social que parte da dissociação entre sujeito e objeto, criando o que hoje conhecemos como pesquisa participante. Muitos pesquisadores que contribuíram no desenvolvimento da teoria da implicação e da pesquisa

\footnotetext{
2 Os dois autores, considerados pertencentes a escolas diferentes da antropologia, contribuíram decisivamente para mudanças metodológicas do trabalho de campo na antropologia e nas ciências sociais em geral, semeando os germens daquilo que viria a ser a teoria da implicação e da pesquisa participante.
} 
participante (BRANDÃO, 1989) viveram anos em comunidades, procurando compreende-las incorporando hábitos, formas de compreensão do mundo e de si mesmos. Tais pesquisadores buscavam, a partir de certo despojamento de seus preconceitos, compreenderem tais comunidades e a si mesmos.

Fazer implicação é pensar em um fazer científico auto-reflexivo, capaz de questionar seus princípios, suas intenções, expondo a todo o momento as contradições que, em certa medida, guiam seus passos, que dá aos mais íntimos detalhes, que em outras pesquisas passariam despercebidos, a ênfase que the cabe. Para além de uma ciência sustentada em um falso discurso de objetividade, faz-se necessária uma outra ciência, implicada em seu tempo e espaço, consciente dos limites, possibilidades, contradições que dizem respeito aos processos sociais dos quais são causa e consequência. Uma ciência feita de dentro, sem deixar-se perder, porém, nas entrelinhas, mas buscando as relações, as implicações dos fenômenos em suas diferentes escalas de ocorrência.

Quais seriam, portanto, as características de uma pesquisa implicada?

Implicação significa, primeiramente, que não se pode isolar certas peculiaridades da pesquisa em si mesmas, que o pesquisador faz parte da pesquisa (no campo, ele é mais um elemento do conjunto, portanto, mais um elemento a analisar) e que ele, consciente ou não, está imerso nessa relação e desempenha um mandato social muito especial... (BAITZ, 2006: 32).

Para Braitz, a implicação cria um outro tipo de intelectual que sabe que a escolha do objeto de pesquisa não se deu ao acaso e por isso explicita as intenções que o levou até ali. Ao fazê-lo, traz a tona um pouco de si, de sua história, da geografia da qual é portador, revelando suas intenções e colocandose também como objeto de pesquisa.

Neste sentido, a escolha de uma análise implicada no caso da EME Profa Alcina Dantas Feijão tem como intuito revelar a parcialidade de nossa interpretação, visto que estamos diretamente envolvidos nos processos e dinâmicas que permeiam tal realidade. Para além de uma pesquisa que se quer absoluta, buscamos relativizar as interpretações aqui realizadas, considerando assim que outras leituras, feitas a partir de outros lugares, também são possíveis.

Já no caso da EE Prof ${ }^{a}$ Ruth Cabral Troncarelli utilizamos elementos da 
etnografia, com o intuito de criarmos a aproximação com uma realidade ainda bastante distante. A etnografia, enquanto técnica de pesquisa antropológica, teve seu desenvolvimento diretamente relacionada a obra do antropólogo norteamericano Clifford Geertz. Em seu livro "A interpretação da Cultura”, GEERTZ aborda uma série de questões relativas ao fazer etnográfico, que se define mais por certas práticas do que por conceito e teorias. Segundo o autor, o fazer etnográfico é aquele que permite ao pesquisador situar-se em relação ao objeto, não em uma posição de distanciamento, mas buscando expandir o contato e interpretar tal objeto levando em consideração sua própria situação. Esta concepção defendida pelo autor parte do pressuposto de que toda cultura existe e se faz existir por meio de um determinado contexto e é papel do etnógrafo compreender, pela sua imersão em tempo prolongado na realidade a ser estudada, este contexto, bem como seus possíveis significados.

GEERTZ define a etnografia como uma descrição densa, na qual o antropólogo inscreve o discurso no contexto social no qual foi produzido. Esta descrição densa que busca compreender uma certa realidade social ocorre exatamente pelo fato de que toda e qualquer realidade está estruturada em uma série de relações sociais, implícitas e explicitas, que muitas vezes para serem desvendadas, necessitam de uma interpretação que partindo da aparência dos fenômenos possa compreender os significados sociais dos mesmos, ocultos nesta rede de relações. Como não se trata de uma realidade inerte, mas dinâmica, em constante processo, cabe ao pesquisador compreende-la em movimento, em suas diferentes relações. Daí a necessidade de uma imersão em tempo prolongado no contexto a ser estudado.

Neste sentido, cabe ao pesquisador que se propõe fazer etnografia, em um primeiro momento, apreender a realidade que é objeto da pesquisa, para que depois, a partir de uma certa interpretação, portadora de limites e possibilidades pelo fato de ser ainda uma interpretação feita de fora, com o olhar do estrangeiro, apresentar um determinado raciocínio que possa explicar os diferentes significados que os elementos em relação assumem naquela determinada realidade. O pesquisador que se propõe fazer etnografia não pode, em nenhum momento de sua pesquisa, esquecer-se de sua condição de diferente, em alteridade com o objeto que estuda. Não pode, de nenhuma maneira, pretender se tornar "nativo" e com isso acreditar que sua interpretação de determinada 
cultura ocorrerá de forma mais próxima de uma certa verdade e que seu olhar revela diretamente todos os significados das ações sociais produzidas e estudadas naquele contexto. O olhar do antropólogo será sempre o de fora, por mais que a visão de dentro seja buscada, sendo que o escrito, a reflexão produzida e transformada em pesquisa e análise não pode, de maneira alguma, com o risco de se comprometer todo o trabalho, ser tomada como reprodução exata de todos os significados da realidade estudada.

Um dos elementos essenciais do fazer etnográfico diz respeito a descrição. A descrição etnográfica tem como principal objetivo trazer a tona elementos da realidade estudada que, em um primeiro momento, passam despercebidos porque analisados como pouco importantes. É na compreensão dos detalhes e da relação dos mesmos com o todo social do qual são elementos constituintes que se fundamenta a diferenciação da descrição etnográficas de outras formas de descrição. Ao utilizarmos a descrição etnográfica no decorrer desta pesquisa buscamos trazer a tona aquelas relações e práticas que em um primeiro momento passam despercebidas. As descrições dos trabalhos de campo e entrevistas

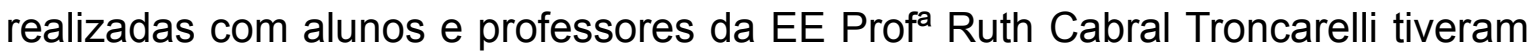
como objetivo, a partir de uma descrição densa como propõe Geertz, desvendar detalhes e perspectivas que em leituras posteriores e mais atentas, tornaram-se objetos de estudo.

Neste sentido, a utilização de elementos da etnografia no desenvolvimento das pesquisas realizadas no EE Profa ${ }^{a}$ Ruth Cabral Troncarelli teve como intuito nos aproximar daquela realidade para que assim pudéssemos realizar uma interpretação, de tantas outras possíveis, das dinâmicas e processos ali existentes. Vale ressaltar aqui que temos clareza dos limites interpretativos que uma pesquisa como a que propomos fazer possui. Porém, sabemos também que tais limites não invalidam as interpretações aqui propostas, principalmente se partimos do pressuposto de que tais interpretações buscam, como tantas outras desenvolvidas, dialogar com outras possibilidades de interpretações.

Dessa forma, apresentadas as questões centrais que permearam nossa pesquisa, passamos a descrição de como ela está estruturada. Inicialmente, faremos uma discussão sobre a relação escola e lugar, buscando analisar e discutir algumas questões pertinentes que utilizaremos no decorrer de nossa pesquisa. Na sequência, abordaremos as questões que envolvem a escola no 
subúrbio, analisando assim as problemáticas envolvendo a EME Prof ${ }^{a}$ Alcina Dantas Feijão. Depois analisaremos os elementos principais que marcam a relação entre escola e lugar na periferia, abordando assim o caso específico da EE Profa Ruth Cabral Troncarelli. Ao fim, buscaremos desenvolver as principais implicações das análises desenvolvidas nesta pesquisa, bem como os pontos de contato entre as duas realidades estudadas.

De forma geral, esperamos que esta dissertação possa contribuir para diálogos profícuos entre aqueles que pensam a escola para além do seu caráter generalizante e que compreendem que aquilo que aquilo que a escola é é também resultado das relações que os seus diferentes sujeitos estabelecem com o lugar do qual são ao mesmo tempo causa, consequência e implicação. 


\section{A relação escola-lugar e suas implicações}

Com base no que foi apresentado até o momento, a Geografia tem papel fundamental na análise da escola enquanto realidade concreta, enquanto espaçotemporalidade em construção. Há uma série de categorias e conceitos geográficos que podem nos auxiliar na elaboração de uma leitura da escola que busque desvendar as relações espaços-temporais entre seus diferentes sujeitos. Em nosso caso, utilizaremos a categoria lugar como mediadora destas múltiplas espaços-temporalidade que se desenvolvem no interior da escola a partir dos sujeitos que dela fazem parte.

O lugar, em suas diferentes interpretações, surge como categoria interdisciplinar. De modo geral, aparece como a escala da realização, do vivido, da experiência. É no lugar que construímos histórias e geografias que portaremos durante toda nossa vida, mas que, em um primeiro momento, ainda não se revelam em toda a sua complexidade. É o nosso primeiro contato com o mundo. Se partirmos do pressuposto de que a geograficidade de cada um de nós se faz a partir das relações que estabelecemos com tudo o que nos rodeia, o lugar é o nosso primeiro mundo, nossa primeira experiência em uma realidade da qual participamos há pouco tempo.

Dessa maneira, pensar o lugar enquanto categoria do pensamento e enquanto escala primeira na qual produzimos e nos reproduzimos enquanto seres humanos é levar em consideração suas diferentes dimensões: afetiva, física, geográfica, escalar, considerando que não existe uma divisão rígida entre tais dimensões. Porém, de forma alguma, pode-se pensar o lugar apenas como proximidade, como realidade já definida posta e conhecida. Como elemento fundante de uma certa espaço-temporalidade, o lugar guarda as escalas mais variadas da realização da vida.

Neste sentido, é preciso partir do lugar, de sua dimensão de proximidade para poder ampliá-lo. É preciso compreender o lugar em suas múltiplas relações, contraditórias, conflituosas, cooperativas, para que se entenda que cada lugar (e os fenômenos que abriga) é resultado de processos sócio-espaciais específicos. O lugar, portanto, revela o mundo. É o particular do / no universal.

Porém, há que se enfrentar um problema fundamental quando se pretende discutir o lugar no interior do pensamento geográfico. Tal problema diz respeito a forma como a categoria lugar está associada a uma idéia de espaço que tem sido 
pensado ao longos dos séculos. Tal idéia parte da priorização dos elementos materiais que compõem o espaço, sem levar em consideração, muitas vezes, as implicações subjetivas e imateriais do qual é causa e consequência. Segundo SMITH,

$\mathrm{Na}$ teoria social ocidental de todo o século $\mathrm{XX}$, a subordinação do espaço ao tempo significou que a diferença espacial foi ignorada ou tratada como trivial: ela penetrava na teoria social somente na medida em que se podiam ver diferentes processos sociais em lugares diferentes. Da mesma forma o espaço per se (em oposição aos eventos sociais que aconteciam "no" espaço ou "através" do espaço) era tratado como auto-evidente, não problemático e sem necessidade de teorização. (2000:139).

Como aponta o autor no parágrafo acima, há uma leitura equivocada da relação entre espaço e tempo, no qual o primeiro aparece como palco, como mero sustentáculo das relações humanas que darão origem a história. Seria, nesta leitura, portanto, o espaço imóvel e cristalizado, sustentáculo do tempo, dinâmica e dialético. Essa concepção de espaço que remonta as teorias da física do século XVI ainda é muito forte em algumas áreas do conhecimento, incluindo a geografia em suas diferentes vertentes. A grande questão que envolve tal concepção diz respeito ao não entendimento das forças sociais como elementos principais na construção do espaço, bem como as implicações imateriais daí decorrentes. Ao se fazer enquanto homem, enquanto ser histórico e geográfico, os homens criam e recriam espaços-temporalidade com as quais passam a se relacionarem, reconstruindo histórias e geografias. Se partirmos de uma concepção do espaço enquanto palco, correremos o risco de entender as escalas geográficas (e aqui está incluindo o lugar) como meros recortes fragmentados de um todo maior. Ainda segundo Smith, é preciso pensar a construção da escala geográfica como uma construção social, permeada por intencionalidades.

A produção e a reprodução contínuas da escala expressa tanto a disputa social quanto a geográfica para estabelecer fronteiras entre diferentes lugares, localizações e sítios de experiência. A construção do lugar implica a produção da escala, na medida em que os lugares são diferenciados uns dos outros; a escala é o critério da diferença, não tanto entre os lugares como entre tipos diferentes de lugares (SMITH, 2000: 142). 
Dessa forma, ao abordamos a questão do lugar e de sua articulação com as problemáticas que envolvem nossa pesquisa, partimos de uma concepção de espaço enquanto construção social, portadora de intencionalidades. Deste modo, - lugar e sua relação com os diferentes níveis da escala geográfica deve ser pensado a partir de um processo dual que resulta em um modo específico de produção do espaço geográfico e, ao mesmo tempo, em um modo específico de produção/reprodução da vida. A escala geográfica, enquanto produção social, deve ser pensada, no modo de produção capitalista, como resultado, ao mesmo tempo, de um processo de diferenciação geográfica que se dá a partir da difusão de elementos fundamentais a reprodução ampliada do capital e de um processo de homogeneização geográfica que se liga a necessidade de concentração espacial do modo de produção capitalista. A uma determinada tendência de diferenciação de áreas, resultado da incorporação de novas infra-estruturas ao território, acompanha um processo de homogeneização territorial que tem como elemento central a necessidade do capital de transformar tudo (pessoas, lugares, coisas) em mercadoria.

Neste sentido, é fundamental compreender de que maneira a lógica do global, regida, em certa medida, pela lógica do capital, se articula/confronta, com a lógica do local, marcada pela produção/reprodução da vida e perpassada por outro importante elemento, que seja, a vida cotidiana. Novamente, atentamos para o cuidado de não se produzir uma leitura dual que contraponha determinados elementos da escala geográfica. Não se trata de uma dicotomia entre local e global, como se cada um destes elementos fossem estanques e prédeterminados. Na leitura que aqui desenvolvemos, apoiada em certos autores citados no decorrer desta dissertação, as escalas geográficas se fazem em relação, em processo e estão, a todo momento, sendo redefinidas. Uma mudança ocorrida em determinado ponto do planeta resulta em transformações que se difundem muitas vezes sem que tenhamos ao certo o tamanho dos impactos que serão causados em diferentes partes do mundo. Da mesma forma, decisões tomadas mundialmente, resultam em implicações locais que não são, de forma alguma, reproduções pacíficas daquilo que se quer impor como norma. As resistências, os conflitos são os principais elementos de transformações e de mudanças das relações entre as diferentes escalas geográficas de realização da vida. 
A abordagem que aqui propomos realizar na qual está em debate a relação entre escola-lugar parte do pressuposto de que o lugar da qual a escola faz parte é também resultado de múltiplos processos realizados em diferentes escalas e por diferentes agentes sócio-espaciais. Para além de uma visão que pense a escola e o lugar fechados em si mesmos, buscamos a compreensão das articulações, das resistências, das contraposições existentes entre os diferentes processos, dinâmicas e fenômenos que mesmo pensados globalmente se realizam no lugar, sem antes, porém, sofrerem as modificações das próprias condições específicas ali encontradas. É assim que, apesar de falarmos em uma sociedade que, pelos menos tendencialmente, tende a ser totalizada pelo modo de produção capitalista, podemos falar da escola no subúrbio e na periferia. Em nossa perspectiva, tais conceitos surgem da própria articulação ocorrida, no lugar, de diferentes formas de sociabilidade, ora articuladas, ora contrapostas ao modo de produção capitalista, o que cria, portanto, uma possibilidade de compreensão mais ampla de tal modo visto que leva em consideração sua especificidade espaço-temporal.

Feita esta ressalva, faz-se necessário, compreender um importante conceito que pode contribuir no entendimento de questões relativas ao lugar, que seja, o conceito de cotidiano. Em nossa perspectiva, o cotidiano, em certa medida, é revelador das relações sócio-espaciais específicas e gerais, bem como de suas implicações na vida de homens e mulheres, em diferentes contextos.

Em seu livro, "Sociologia da Vida Cotidiana", Agnes Heller faz a seguinte afirmação:

\footnotetext{
Para reproduzir a sociedade é necessário que os homens particulares se reproduzam a si mesmos como homens particulares. A vida cotidiana e o conjunto de atividades que caracterizam a reprodução dos homens particulares, os quais, por sua vez, criam a possibilidade da reprodução social. (HELLER,1994: 19).
}

A vida cotidiana é, portanto, segundo a autora, resultado da reprodução da vida dos homens particulares que, em sua relação com os elementos gerais que definem determinados conceitos e práticas, recriam-nas e se recriam como sujeitos particulares. A particularidade própria da vida cotidiana é, portanto, um dos elementos fundamentais para a compreensão das relações que estabelecem 
entre os diferentes elementos espaços-temporais que marcam a reprodução da vida.

No livro "Cotidiano e História", da mesma autora, esta concepção da relação entre o geral e o particular aparece de forma mais clara.

$\mathrm{Na}$ vida cotidiana, a esmagadora maioria da humanidade jamais deixa de ser, ainda que nem sempre na mesma proporção, nem tão pouco com a mesma extensão, muda unidade vital de particularidade e genericidade. $O$ fato de se nascer já lançado na cotidianidade continua significando que os homens assumem como dadas a funções da vida e as exercem paralelamente (HELLER, 1988:23)

Concebido o cotidiano como algo já posto e do qual passam a fazer parte desde o momento de seus nascimentos, homens e mulheres do mundo todo, realizam-se também, ao mesmo tempo, como seres particularidades, portadores de certos elementos específicos, mas que se fazem nas múltiplas relações que estabelecem diariamente. Em certa medida, tais relações são dadas como normais, como sempre existentes, o que leva tais homens e mulheres a definir o cotidiano como algo repetitivo, desprovido de novidade e com pouca abertura para transformações. Em certo caso, cotidiano transforma-se em adjetivo pejorativo para alguma atividade que se realiza de forma repetida e com pouco significado. Fala-se da rotina, do trabalho, do cansaço que o cotidiano traz.

Neste sentido, é importante compreender de que forma é possível fazer aflorar aqueles elementos presentes no cotidiano que aparecem ocultos na ordem da repetição e que são resultados, na atualidade, da incorporação cada vez mais intensa, do cotidiano, a outras ordens, e outras estratégias de reprodução que, em certo sentido, negam aos homens a própria reprodução da vida. Ao pensarmos o momento histórico e geográfico atual, no qual há um avanço significativo das tecnologias de informação, comunicação e transporte, faz-se necessário compreender o cotidiano como reprodução da vida e sua negação, incorporado, aos poucos, por outras lógicas que implodem a vida e reproduzem os homens não mais como sujeitos mas como objetos desta ordem que vai além do cotidiano mas que nele realiza sua reprodução.

Como vimos, a repetição é o principal elemento responsável pela ocultação dos processos sócio-espaciais que perpassam o cotidiano. A repetição cria a 
familiaridade e transforma, em certa medida, exceções em regras. Segundo Bertold Brecht, faz-se necessário partir do cotidiano para dele se afastar e a ele retornar com uma outra forma de ver, de enxergar, de compreender os processos sociais que nele se ocultam. Para tanto, ainda segundo Brecht, é necessário transformar o comum em incomum, o normal em anormal, o familiar em estranho, lançando, em outras situações e contextos, elementos e processos considerados seguros e dados. A partir disso, cria-se o que Brecht denomina de "efeito de estranhamento", que ficou conhecido na linguagem teatral como efeito K. Tal conceito e os processos que levam a ele podem ser encontrados no seguinte poema do autor:

\footnotetext{
Desconfiai do mais trivial, na aparência singelo. E examinai, sobretudo, o que parece habitual. Suplicamos expressamente: não aceiteis o que é de hábito como coisa natural, pois em tempo de desordem sangrenta, de confusão organizada, de arbitrariedade consciente, de humanidade desumanizada, nada deve parecer natural nada deve parecer impossível de mudar.
}

No caso da Geografia, é o lugar o lócus no qual o cotidiano se reproduz. Não existe cotidiano sem lugar. É na conformação surgida da relação entre lugar e o cotidiano que surge e se realiza uma certa singularidade sócio-espacial, portadora de particularidades, resultantes das relações especificas que ali ocorrem, que são também pluralidades, no sentido em que compõe uma rede de outros lugares e cotidianos, ao mesmo tempo parecidos e diferentes. É ali que as relações, de diferentes formas e maneiras, se tornam reais e sua repetição as faz familiares. Apesar de todo turbilhão de insegurança decorrente, em grande medida, das contradições produzidas em diferentes escalas pela reprodução ampliada do modo de produção capitalista, é no lugar e em suas relações cotidianas que os homens procuram as referências de segurança e familiaridade que Ihes escapam em outras escalas. O lugar e o cotidiano são, portanto, referências primeiras de segurança porque familiares.

Como segurança, lugar e cotidiano podem também se transformar em aprisionamento. Muitas vezes, funcionam como calabouço que, limita ações, reduz possibilidades, reproduz lógicas que fazem pouco sentido a vida dos 
homens que delas fazem parte. Segundo Damiani, a reprodução do lugar e do cotidiano, podem resultar num esvaziamento das relações sociais que ali se realizam e na construção do lugar e do cotidiano enquanto simulacro.

A realidade ordinária, cotidiana, que nasce no lugar e o constitui, feita de fatos e situações, que mantém a vida, pode e é o que torna a cotidianidade um tema a se examinar, compreendendo "o extraordinário no ordinário", o "sentido do insignificante". Dessa forma, a história pode começar no lugar. Mais apropriadamente, e a esse respeito, a profunda especialização dos lugares, com a mundialização, retira do lugar sua historicidade complexa, e ele tende a simulacro da história. Quanto mais inserido na mundialidade, mais apartado da história, ainda mais se torna um sistema fechado em suas possibilidades. A contestação o recoloca no movimento da história. Liberta-o. (DAMIANI, 2002: 164).

Porém, o cotidiano não é apenas isso. Para além de sua mera negatividade, é no cotidiano que homens e mulheres específicos realizam suas vidas, ainda que sem toda a sua potencialidade. Por mais que o modo de produção dominante por meio de seus principais agentes busque controlar 0 cotidiano, programá-lo a favor de sua reprodução ampliada, coexistem resíduos e resistência de outras sociabilidades e são elas que aqui nos interessam. Para tanto, é necessário recolocar o lugar para que a aparência de e harmonia seja substituída por uma leitura crítica das relações que ali se estabelecem. Ao invés de aprisionar, de criar apenas limites, o lugar deve possibilitar aos homens compreenderem as diferentes lógicas que buscam reduzir a vida à forma mercadoria. O homem aprisionado no lugar, trancafiado em uma realidade da qual pouco entende é o homem alienado de suas reais condições. Da mesma forma, o homem arremessado no mundo, colocado no eterno movimento do não-lugar é o homem incapaz de compreender sua condição de ser espacial, criador de geograficidades. A moderna lógica do desenraizamento que faz os homens não se sentirem em casa em lugar nenhum é um dos principais reveladores da apropriação do lugar e da vida cotidiana pela lógica do capital e da mercadoria.

Como vimos, é no lugar que as diferentes lógicas de poder correlacionam forças. O lugar dos homens desenraizados é também lugar da reprodução do poder enquanto força e violência simbólica. Portanto, ao se pensar o lugar, é 
preciso compreendê-lo também enquanto ponto de contato entre a lógica que imponho ao mundo e a qual o mundo me impõe. Ao construir o lugar, refaço o mundo, apresentando-Ihe uma outra lógica ainda não totalmente programada. $\mathrm{O}$ lugar permite aos homens tocar o chão com os pés. Permite-lhes deixarem rastros. Nestes rastros, constroem os homens suas memórias, significados, pertencimentos. Com elas, escrevem uma nova Geografia do mundo, uma nova geografia do poder.

Neste sentido, a crítica ao cotidiano deve partir, com base nos pressupostos aqui desenvolvidos, de uma crítica das relações sociais que ocorrem no lugar e que são uma das bases na qual se sustentam os processos sociais presentes no cotidiano. O lugar revela e ao mesmo tempo oculta, traços de uma ordem cotidiana na qual os homens são, ao mesmo tempo, sujeitos e objetos, e o são, muitas vezes, sem disso terem consciência. O cotidiano se revela, como dissemos, no nível da repetição e de uma repetição que é prática, não reflexiva. Não é possível esperar que a reflexividade do sujeito inserido no lugar e no cotidiano nasça das relações familiares que estabelece. É preciso que ocorra intervenção crítica, que provoque o estranhamento.

$\mathrm{Na}$ escola, para aqueles que a observam com um olhar mais desatento, o domínio da repetição parece total. As práticas pedagógicas reproduzem-se anos após anos e vão, se tornando, com o tempo, cada vez menos significativas. Porém, tais práticas ocultam conflitos e situações que fogem a esfera do controlável e da repetição. Tais situações emergem em diferentes momentos, provocados por diversas situações surgidas das múltiplas relações que ali se estabelecem. Dizer que na escola os fatos estão postos e que, portanto, pouca coisa acontece é desviar os olhos daquilo que há de mais fundamental naquele espaço social, que seja, as relações sociais que, por intermédio dele, ocorrem.

Pensar o espaço social escola como dinâmico, em processo constante de construção, é ao mesmo tempo fazer emergir, vir a tona, os conflitos presentes e as contradições que permeiam as relações sociais ali estabelecidas e possibilitálas de um certo entendimento, para que não se tornem resultados do acaso ou de coisa que o valha. E aqui, em nosso ponto de vista, a geografia tem papel fundamental. Partir da escola real, dos processos realmente existentes em direção as múltiplas escalas com a qual a mesma está direta ou indiretamente relacionada se configura enquanto tarefa essencial para uma compreensão mais 
profunda dos diversos processos que permeiam a escola e seus diferentes sujeitos. Não se trata nem de se perder demasiadamente no interior da escola, nem de correr o risco de se produzir uma abstração generalizante sobre o tema. O desafio está em encontrar os pontos de contato, as conexões que existem entre as diferentes escalas sócio-espaciais que interferem e influenciam nas relações que se estabelecem no interior da escola e em seu entorno. 


\section{A escola no subúrbio: o caso da EME Prof ${ }^{a}$ Alcina Dantas Feijão}

Nesta parte de nossa dissertação, analisaremos algumas das observações que realizamos como pesquisador e professor da EME Profa Alcina Dantas Feijão em São Caetano do Sul. O "Alcina", como é conhecido tradicionalmente é uma das escolas mais antigas e tradicionais de São Caetano do Sul. A escola surgiu na década de 1960 da necessidade de formação de mão de obra técnica para as diferentes empresas da cidade. Este fato justifica o primeiro nome recebido pela Escola, Colégio Comercial de São Caetano do Sul. De lá para cá, a escola sofreu uma série de transformações em seu nome que denotavam uma mudança de seu significado e de sua função social no interior da cidade.

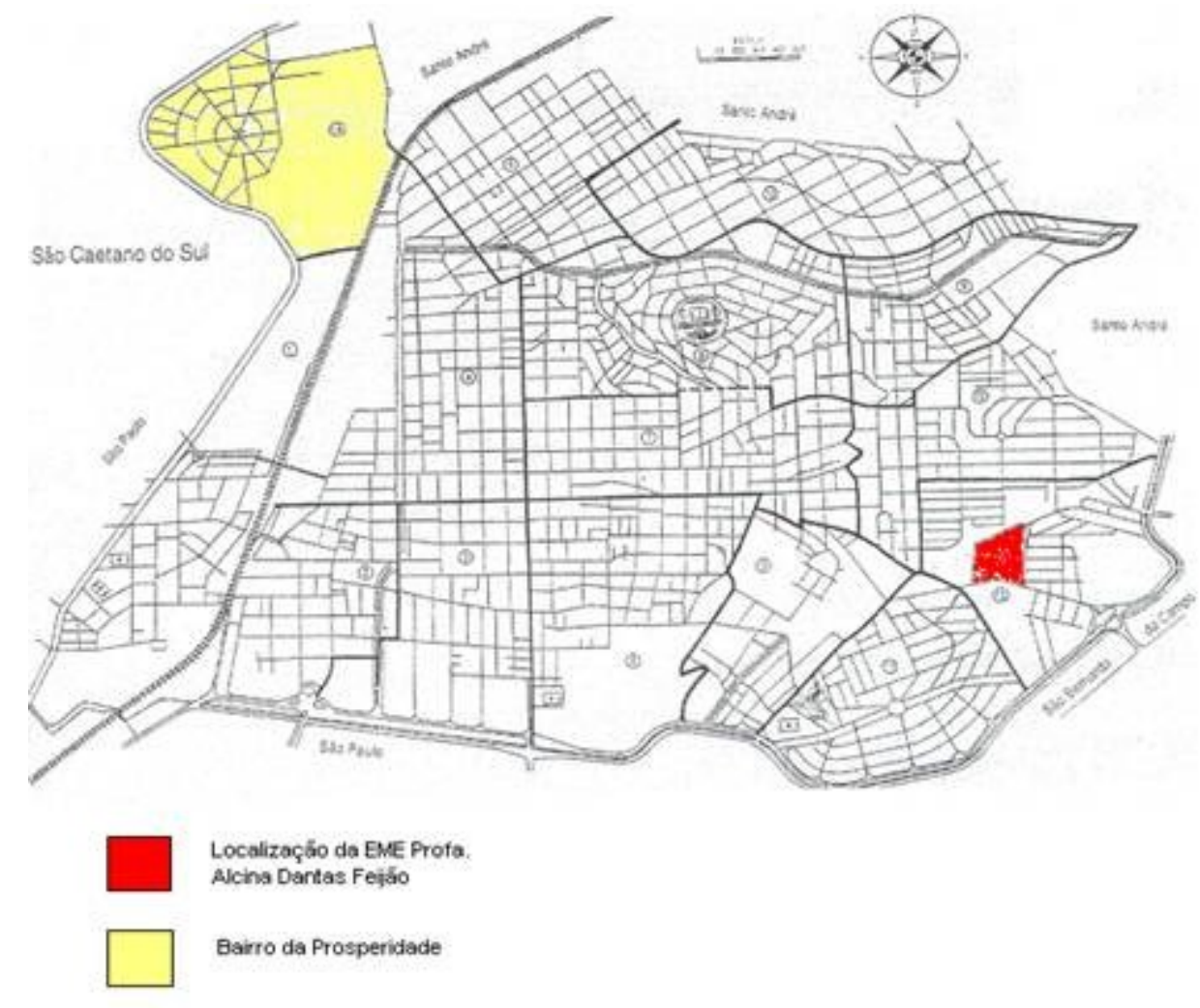

Figura 1: Mapa do Município de São Caetano do Sul. Em destaques, o Bairro da Prosperidade e a localização da EME Profa ${ }^{a}$. Alcina Dantas Feijão. Adaptado de MARTINS, 1987.

Minha relação com o "Alcina", começou em fevereiro de 2007. Vale ressaltar que as observações que aqui faço são restritas aos anos de 2007 e 2008, visto que, pela própria dinâmica temporal do processo de pesquisa não foi possível ampliar as discussões para outros anos. Essa ressalva torna-se importante no sentido em que, se tratando do Alcina, a cada quatro anos, 
mudanças radicais ocorrem a partir de alterações ligadas a própria dinâmica política da cidade. Mas este é um assunto que desenvolveremos mais adiante.

Após ser aprovado no concurso público da prefeitura de São Caetano do Sul, escolhi lecionar no Alcina. Não sabia quase nada sobre a escola. No entanto, a escolhi por se tratar, no momento, da única escola da rede municipal que possuía Ensino Médio, nível de Ensino ao qual tenho preferência em lecionar. Ao me apresentar para assumir as aulas, encontrei uma escola em total reforma. Tudo estava sendo trocado, das carteiras as lousas, do chão as janelas. Um anfiteatro com capacidade para quase trezentas pessoas estava sendo construído. O barulho era ensurdecedor. Nos corredores da escola, funcionários trabalhavam rapidamente para tentarem organizá-la minimamente para o ano letivo que iria se iniciar na próxima semana.

Confesso que a primeira sensação que tive é que havia feita a escolha certa. Afinal de contas, qual professor, frente à realidade da educação pública do Brasil, não se sentiria privilegiado por lecionar em uma escola totalmente reformada e com uma excelente infra-estrutura? O pouco que já havia lido sobre o Alcina sabia que se tratava de uma das melhores escolas públicas de São Caetano do Sul, destacando-se também em todo o ABC. O que mais chama a atenção no Alcina para os novatos como eu é, ao mesmo tempo, seu gigantismo e sua organização. São mais de três mil alunos nos três períodos de aula. A escola oferece desde a Educação Básica (Ensino Fundamental I e II ao Ensino Médio) ao Ensino Técnico e Profissionalizante. Conta com um quadro de mais de 100 professores, um grande número com pós-graduação e mestrado.

Apesar de seu gigantismo, a escola possui um nível de organização que se pauta por uma idéia de qualidade de ensino alicerçada nos resultados obtidos em avaliações nacionais, como o ENEM. Em relação à organização pedagógica, a seriação e a reprovação são práticas existentes e bastante valorizadas por professores e pais (segundo alguns pais e professores, em conversas informais, o que garante a qualidade de ensino em toda a rede municipal é a não adoção do sistema de progressão continuada e a continuidade da reprovação somado a um intenso investimento no sentido de possibilitar aos alunos reforço escolar). O número de alunos por sala é limitado a 35 , sendo que, em algumas não ultrapassa 25. A escola é equipada com laboratório de ciências, escritório modelo, laboratório de publicidade, quatro laboratórios de informática, anfiteatro, ginásio 
poliesportivo, laboratório de fotografia, biblioteca.

Em relação ao Ensino Médio, o Alcina apresenta uma diferença em relação a outras redes de ensino, pelo fato do aluno optar, a partir do segundo ano, por desenvolver uma ênfase. As ênfases oferecidas são administração, processamento de dados, publicidade e secretariado, que compõem a parte diferenciada do currículo do ensino médio, o que, em certa medida, aponta uma preocupação de formação dos alunos para o mercado de trabalho.

No Alcina, o ingresso no Ensino Médio é feito por meio de vestibulinho apesar de alguns alunos afirmarem que o ingresso ocorra, muitas vezes, por intermediação do padrinho político. As questões relacionadas ao vestibulinho (forma de aplicação e de correção, elaboração da prova, entre outras) são reveladoras de conflitos existentes entre os diferentes grupos políticos da cidade. Em um destes conflitos, houve intervenção direta da diretoria de educação de São Caetano do Sul na aplicação e correção do vestibulinho de 2008. Como representam grupos políticos de visões opostos, a diretora de educação e a diretora do Alcina, no ano de 2008, fizeram daquele momento, comum na rotina da escola, lócus de disputa de poder que marcam algumas das relações sócioespaciais que ocorrem em São Caetano do Sul.

Por se tratar da escola mais tradicional de São Caetano do Sul, os alunos que nela ingressam possuem um nível de renda elevado (classes $B$ e $C$, em sua grande maioria), além de muitos deles serem filhos de famílias importantes no quadro político da cidade, sendo muito comum a presença de filhos e parentes de vereadores. 


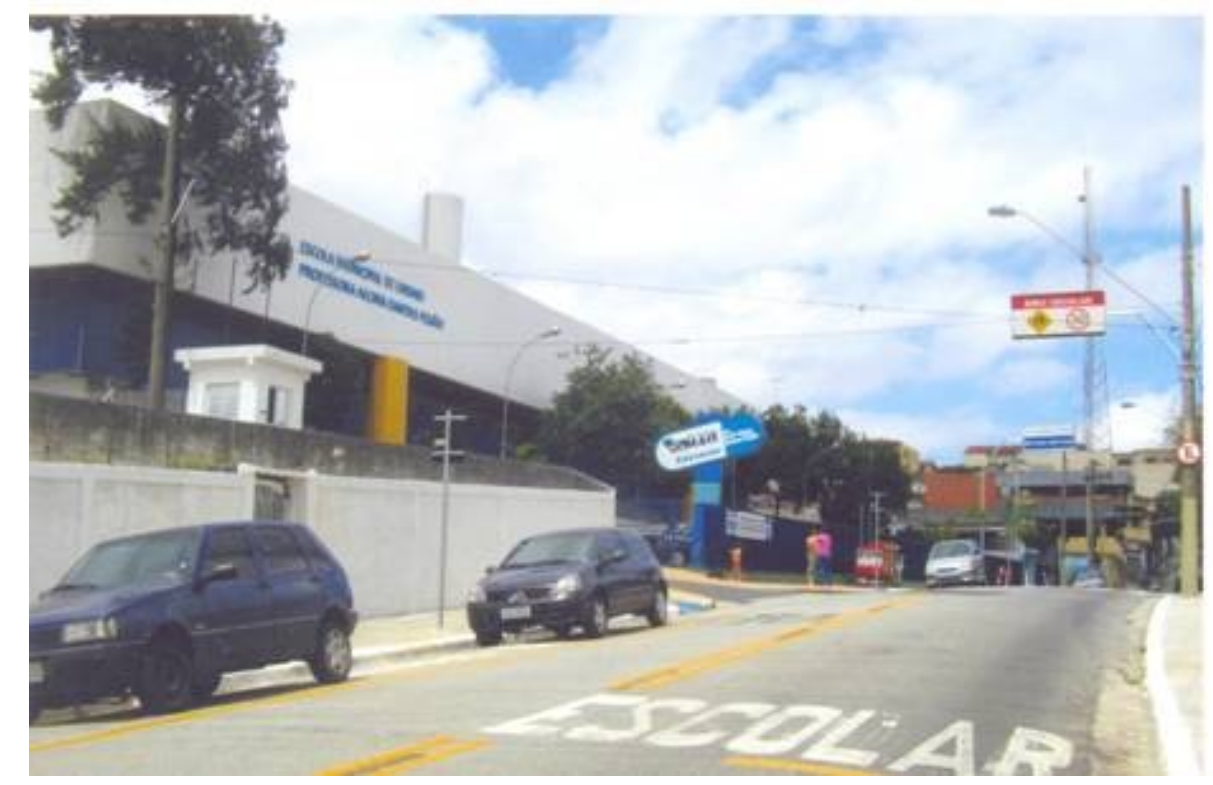

Figura 2: Rua Capivari, no Bairro Mauá. Do lado esquerdo, fachada recémreformada da EME Profa. Alcina Dantas Feijão. Foto do autor, novembro de 2007.

Quando afirmo que o Alcina é uma escola tradicional levo também em consideração a forma como o processo de ensino-aprendizagem é concebido. Tal tradicionalismo se acentuou com a indicação da atual gestão para o período de 2005 a 2008. O processo educativo centralizou-se no professor. Um sistema apostilado visa garantir a padronização dos conteúdos. As regras são rígidas e mantidas por uma direção bastante centralizadora e, em certa medida, autoritária. Atividades extraclasse são dificilmente permitidas. Não existe grêmio na escola, nem mesmo grupo de teatro. Há uma semana por bimestre dedicada a prova que é encarada como um vestibular mensal. Nesta semana, a tensão dos alunos é enorme. Não é difícil encontrar os mesmos pelos corredores, na lanchonete, tentando decorar algumas fórmulas de matemática ou de física para a prova bimestral. Há uma generalização da prática de cola que, para alguns alunos, é a única forma de se conseguir obter nota em determinadas provas. Em conversas com alunos, fui informado que entre os métodos de cola mais utilizados estão a troca de provas e gabaritos, esta última feita entre alunos de diferentes períodos.

Outra prática interessante observada no Alcina, reveladora da forma como se constitui o processo educativo naquela unidade escolar, diz respeito ao aumento do número de transferências que se verifica conforme o final do ano se aproxima. $\mathrm{O}$ auge de transferências ocorre no fechamento de notas no terceiro 
bimestre. Como a média necessária para ser aprovado no Alcina é sete, o que, para os alunos, é muito alto e com medo de perderem o ano, muitos alunos se transferem para Escolas Estaduais, consideradas menos exigentes por adotarem o sistema de progressão continuada, na quais, segundo eles, "nunca reprovarão". Se juntarmos o isso o processo de fechamento do turno noturno, que vem se constituindo enquanto prática da atual administração da unidade escolar, podemos afirmar que está sendo posto em prática um processo claro de seleção dos alunos que devem estudar no Alcina. Alunos trabalhadores, muitas vezes em decorrência da baixa renda e da necessidade de contribuírem para os rendimentos mensais familiares, aos poucos estão sendo privados das condições de educação existentes no Alcina ${ }^{3}$.

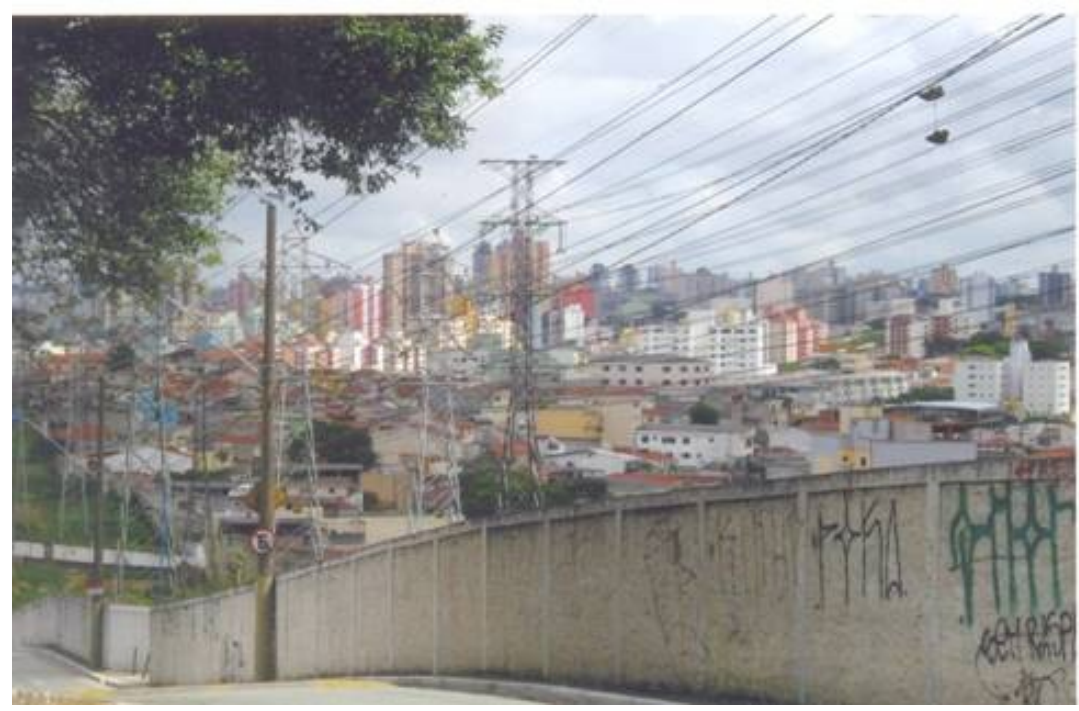

Figura 3: Vista geral do entorno da EME Profa. Alcina Dantas Feijão. Ao fundo, pode-se observar o bairro de Rudge Ramos, situado em São Bernardo do Campo.

Em relação às transferências, que ocorrem em maior número conforme se aproxima o final do ano letivo, a maioria dos alunos transferidos são do período noturno. Consiste, basicamente, em alunos trabalhadores, que chegam as aulas exaustos e, muitas vezes, atrasados. Não existe no Alcina nenhuma diferenciação

\footnotetext{
${ }^{3}$ No final de 2008, um grupo de alunos do $3^{\text {a }}$ ano do período noturno, a partir de uma discussão/debate realizada com os professores de história e geografia sobre o direito ao ensino noturno de qualidade, organizaram um abaixo-assinado, mobilizando uma importante parcela da comunidade escolar, o qual foi entregue tanto para a diretoria da unidade escolar, quanto para a diretora de educação. A pressão exercida pela mobilização da comunidade escolar, obrigou a diretoria a rever sua posição em relação ao fechamento do ensino médio noturno e, possivelmente, para o ano de 2009, ocorrerão matrículas noturnas.
} 
de conteúdos, procedimentos, métodos e cobrança entre os diferentes períodos. O que é cobrado dos alunos do Ensino Médio de manhã é cobrado a noite. Este fato faz com que muitos alunos do noturno não consigam acompanhar o ritmo e desistam no último bimestre.

Outro elemento importante para se compreender as relações sócioespaciais que ocorrem no interior do Alcina, diz respeito ao fato de, por se tratar, até pouco tempo, da única escola Municipal de Ensino Médio de São Caetano do Sul, reúne alunos dos mais diferenciados bairros da cidade. A imagem de escola tradicional e de qualidade é o principal fator que leva os alunos da cidade a buscarem o Alcina. Não se configura, portanto, como uma escola de bairro. É, antes, lugar no qual, as relações sociais dos diferentes moradores da cidade se realizam. É lugar, portanto, privilegiado para se compreender as múltiplas relações sociais existentes na cidade e que se deixam desvelar nas relações existentes no interior da própria escola.

O desenvolvimento de minha prática pedagógica no interior da EME Profa Alcina Dantas Feijão me levou a percepção de que, muito do que ocorre no interior desta unidade escolar, diz respeito à dinâmicas sócio-espaciais relacionadas a especificidades políticas e sociais existentes na cidade. Foi desta percepção que surgiu a necessidade de compreender um pouco mais de que formas se davam as relações entre a escola (por meio de seus diferentes sujeitos) e o lugar, buscando assim o entendimento das especificidades que caracterizam São Caetano do Sul. Em minha perspectiva, só a partir desta compreensão é que poderia analisar mais detalhadamente os processos no qual, até aquele momento, aparecia como mero observador.

\subsection{O desvendamento do lugar}

São Caetano do Sul tem ganhado destaque, nas últimas décadas, por apresentar um dos mais elevados Índices de Desenvolvimento Humano no Brasil. Em 2000, segundo dados do PNUD, a cidade aparecia na $1^{\circ}$ colocação nacional, com o IDH de 0,919. Em certa medida, esta classificação refere-se a realidade vivida, pelo menos, por parte da população. A cidade apresenta $100 \%$ de urbanização, contando com acesso à água potável e sistema de coleta de esgoto, apesar de ainda não existir tratamento para todo o esgoto coletado. Apresenta 
também índices elevados de expectativa de vida e de renda per capita. No que concerne a Educação, no ano de 2007, a cidade recebeu o selo do MEC dado a todas as cidades que erradicaram o analfabetismo e, por cinco anos seguidos, alcançou o primeiro lugar em escolaridade no Índice Paulista de Responsabilidade Social publicado pela Fundação Sistema Estadual de Análise de Dados (SEADE). A cidade apresenta uma rede pública de educação muito bem estruturada, contando com escolas de ensino infantil, fundamental e médio, além de uma universidade subsidiada pela prefeitura. No ano de 2007, foi inaugurada a primeira faculdade pública da cidade, a $\mathrm{Fatec}^{4}$ de São Caetano do Sul, que funciona no mesmo prédio da $\mathrm{ETE}^{5}$ Jorge Street.

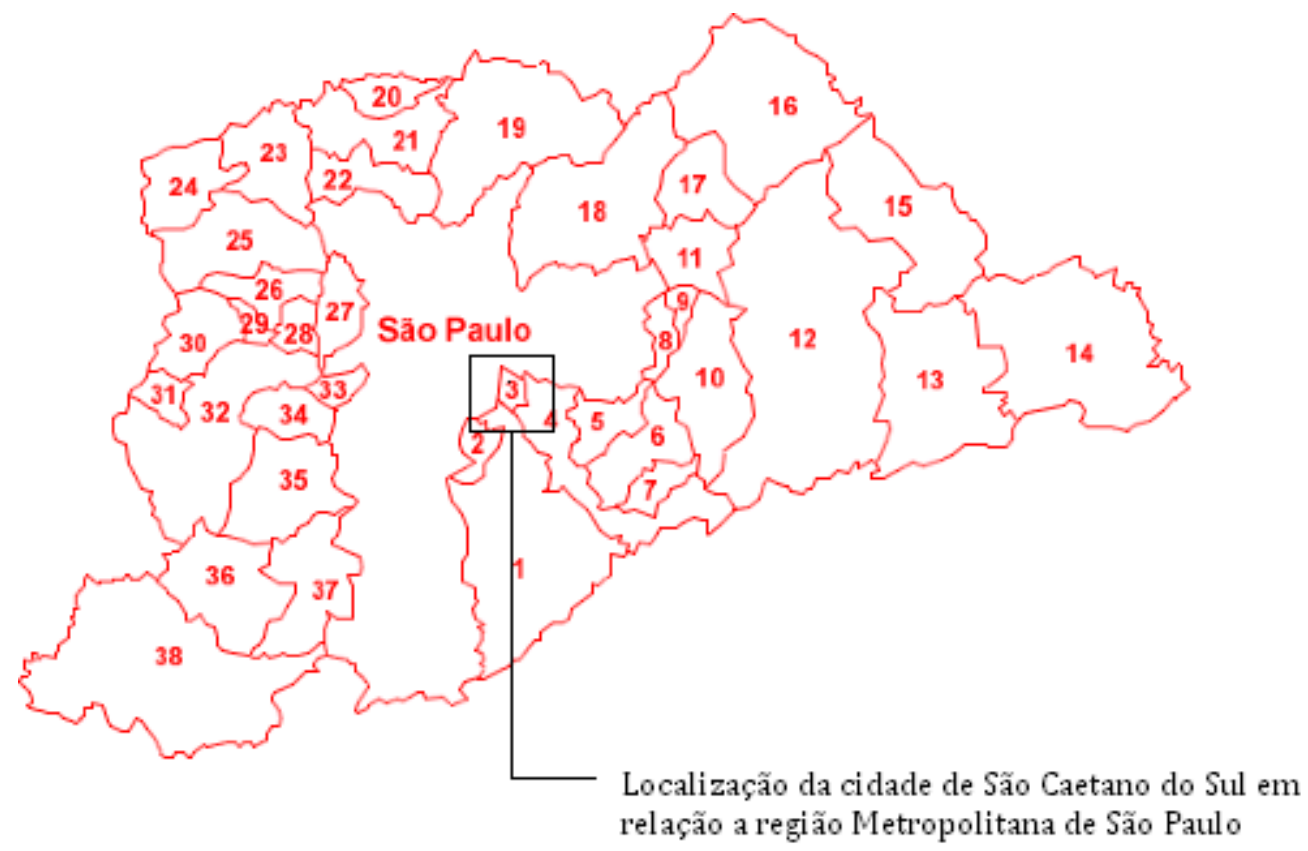

Figura 4: Localização da Cidade de São Caetano do Sul em relação à Região Metropolitana de São Paulo. Fonte: www.saocaetanodosul.sp.gov.br. Mapa sem escala.

Um dos elementos que marcam a especificidade das práticas sócioespaciais encontradas em São Caetano do Sul diz respeito a sua extensão territorial. A cidade possui cerca de $15 \mathrm{~km}^{2}$, o que possibilita aos seus moradores outras relações sócio-espaciais que nas cidades de maior porte são pouco presentes. Quase todo mundo se conhece em São Caetano do Sul. É difícil "passar despercebido". Aquela sensação de não-reconhecimento, de um entre

Faculdades de Tecnologia de São Paulo.

Escola Técnica Estadual. 
tantos que marca a realidade dos grandes centros urbanos do mundo e que tem como elemento central o fenômeno da massa, descrito e analisado por Elias Canetti em seu livro "Massa e Poder", é dificilmente encontrado nas falas dos moradores de São Caetano do Sul e dos alunos que frequentam a EME Prof ${ }^{a}$ Alcina Dantas Feijão. Para muitos, a cidade ainda se organiza como uma antiga comunidade de imigrantes que tem como elemento central um certo senso de solidariedade que pressupõe o reconhecimento do outro e de suas condições. No imaginário da população, como pudemos perceber em entrevistas e conversas informais realizadas com moradores e alunos, a idéia de "aldeia" surge como um dos elementos definidores do que vem a ser as características das relações sócio-espaciais em São Caetano do Sul.

Quando alguém tem algum problema, procura o próprio prefeito para reclamar ou fazer alguma solicitação. O mesmo, por sua vez, faz-se presente em muitos momentos da vida dos habitantes. Apesar do pouco tempo no qual leciono no Alcina, pude presenciar muitas visitas do prefeito e de membros da Câmara dos Vereadores na escola. Algumas vezes, com vistas a tratar de assuntos referentes a alguma área específica; por outras, apenas para marcar presença e ganhar visibilidade. Esta presença constante do poder político na vida cotidiana dos moradores de São Caetano do Sul dá aos mesmos uma sensação de proximidade em relação ao poder representativo que em outras cidades se torna mais difícil pelas próprias condições geográficas. Por sua vez, esta proximidade resulta em um sentimento muito forte de pertencimento, pelo menos por parte da população local, que se reflete nas falas e nos discursos dos moradores e que resulta, também, em cobranças, não muitas vezes agradáveis, aos poderes públicos constituídos.

Esta sensação de pertencimento resulta também na construção de uma em uma extensa história local que pode ser facilmente consultada nas publicações realizadas pela fundação Pró-memória. Tal fundação, junto com o Museu Municipal, foram criações da municipalidade com o objetivo de reconstruir a história local de São Caetano do Sul, buscando inseri-la na história de São Paulo e do Brasil. Tal história local é difundida por meio das escolas e se reproduz, muitas vezes, sem o questionamento e a crítica necessária para sua compreensão. 


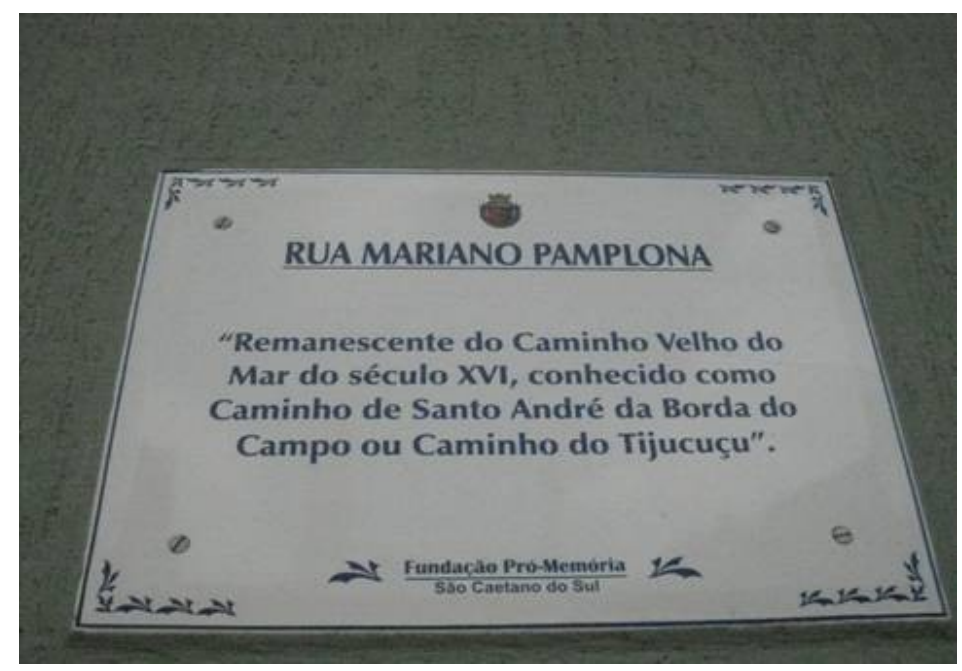

Figura 5:Placa indicativa da Rua Mariano Pamplona produzida pela fundação PróMemória que busca, reconstruindo a história de São Caetano, inseri-la em outros momentos da história de ocupação do território Brasileiro. Foto do autor, janeiro de 2009.

Tais elementos que marcam a sociabilidade de São Caetano do Sul e que podem, facilmente, serem verificados nas relações cotidianas entre os diferentes sujeitos que se encontram na EME Profa Alcina Dantas Feijão e que em certa medida compõe os elementos definidores da cultura escolar ali encontrada, nos ajudam a compreender o porquê utilizamos o conceito de subúrbio, nos remetendo a obra de José de Souza Martins, para designar a cidade, bem como as relações sócio-espaciais que ali acontecem. Esta discussão, que nos fará afastar-nos, neste momento da pesquisa, da escola estudada, para que possamos a ela voltar tendo nossos horizontes e perspectivas ampliados, se faz necessária no sentido em que nos possibilita compreender de que maneira estas relações sócio-espaciais que ocorrem no subúrbio e que em certa medida o definem, são fundamentais para se entender as práticas e as relações ocorridas na escola estudada e seus significados em São Caetano do Sul. Porém, para além de uma definição de subúrbio que parta apenas de sua localização, acreditamos ser necessário analisar de que maneira determinadas sociabilidades, determinados modos de vida se reproduzem naquele contexto, bem como quais são os elementos fundamentais destas relações.

Em seu livro "Subúrbio", Martins analisa a formação do núcleo colonial de São Caetano do Sul a partir do desenvolvimento do conceito de Subúrbio. Segundo o autor, o subúrbio se define enquanto o componente rural do urbano. No subúrbio, as relações que os moradores estabelecem entre si e com o lugar 
dizem respeito ainda a resquícios da lógica do rural. O que define, muitas vezes, a posição social no interior desta sociabilidade de São Caetano do Sul são as relações de parentesco que um determinado sobrenome revela. É possível perceber isso no contato diário com os alunos. Os mesmos se reconhecem e são reconhecidos muitas vezes mais pelo nome que carregam do que pela condição financeira que possuem. Tal nome, por sua vez, revela uma posição também na tão difundida história local. Participar de uma família, portanto, significar estar mais próximo ou distante desta história oficial da cidade. Aqueles, porém, que não carregam tais sobrenomes sofrem com o peso do desconhecimento e com as consequências políticas daí advindas.

Desde o início do processo de ocupação territorial de São Caetano do Sul, os vínculos estabelecidos pelas primeiras famílias foram fortalecidos, em certa medida, em decorrência da difícil situação econômica e de reprodução da vida em que a maioria dos moradores se encontravam naquele momento. Estas dificuldades eram resultados também da distância existente entre a cidade - neste caso, São Paulo - e o subúrbio, como se, pelo menos em aparência, o subúrbio fosse a negação da cidade. A ajuda mútua, o estreitamento dos laços sociais foram as alternativas encontradas para que se pudesse suprir a ausência da cidade, representação do poder político. No vazio deixado pela ausência da cidade, os moradores recriaram suas identidades enquanto identidades, também, coletivas. Criou-se, neste sentido, a idéia de aldeia, de sociedade fechada, identificada pelo sobrenome, característica marcante da sociedade atual de São Caetano do Sul.

Esta sensação de vazio deixado pela ausência do poder público nos primeiros anos de formação do núcleo colonial de São Caetano do Sul, de forma geral, está relacionado ao fato de que, como subúrbio, o núcleo criou seu desenvolvimento à margem da cidade de São Paulo, ainda que a mesma fosse fundamental para a sua reprodução.

Mas quais são os significados da cidade de São Paulo na percepção dos moradores do núcleo colonial nos primeiros anos de sua formação? De modo geral, a cidade faz parte da ordem do distante, do desconhecido, daquilo que deve ser visitado apenas em último caso ${ }^{6}$. É também o lugar do poder econômico

6 Para muitos dos colonos de São Caetano do Sul, a cidade de São Paulo se apresentava como lugar da morte, do descanso eterno. Em seu livro, Diário de Fim de Século, José de Souza Martins organiza uma série de anotações que datam dos primeiros anos do núcleo colonial. Entre elas destacam-se os registros 
e político, lugar das decisões e das ameaças que dela surgem. O subúrbio está à margem da cidade. O que acontece na cidade passa, muitas vezes, despercebido da vida cotidiana que se realiza no subúrbio. Por sua vez, porém, o subúrbio participa da cidade enquanto elemento fundiário essencial para a reprodução ampliada do capitalismo industrial. Isso explica, no caso da relação entre São Paulo e São Caetano do Sul, a expansão industrial para o subúrbio. Explica também, as transformações espaciais ocorridas nesta área no início do século XX. É da relação contraditória marcada, ao mesmo tempo, pela ameaça representada pela cidade e por sua ausência que a vida no subúrbio desenvolve traços específicos e que tem no fortalecimento dos laços comunitários e na solidariedade local seus principais elementos de sustentação.

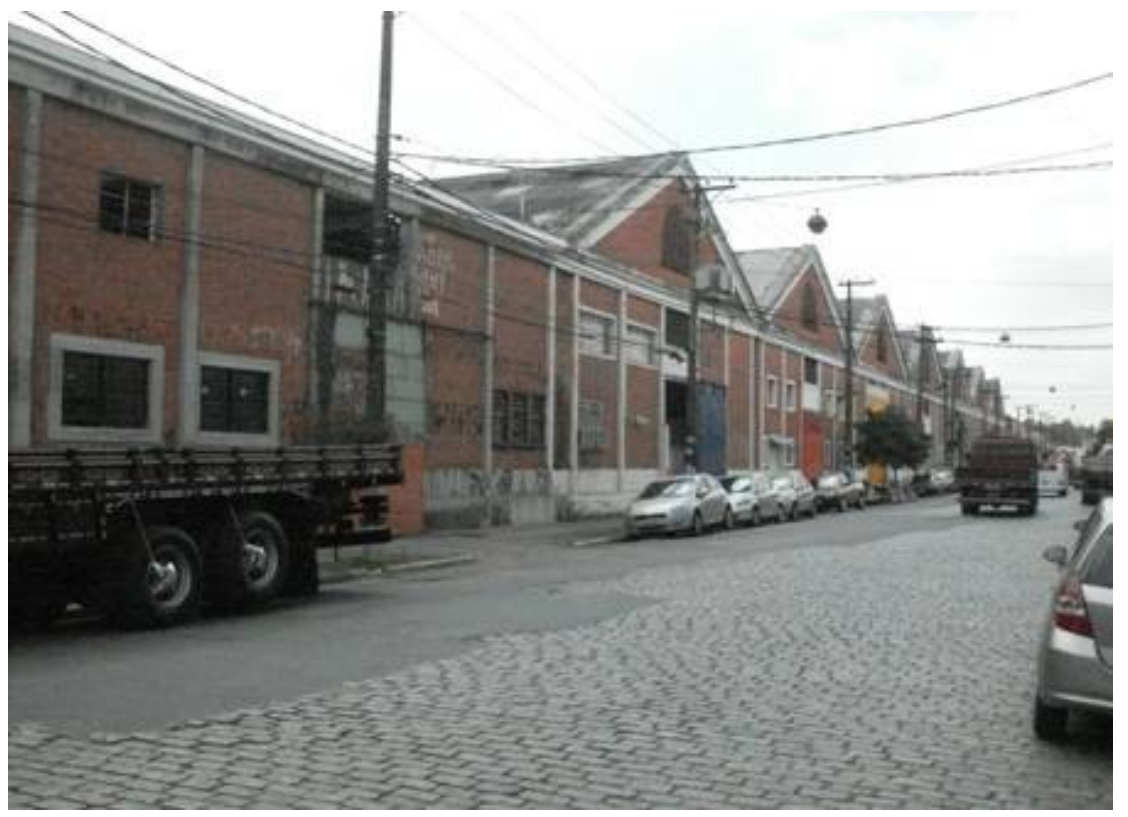

Figura 6: Vista da Avenida Henry Ford que liga São Caetano do Sul a cidade de São Paulo. A grande concentração industrial nesta Avenida, ocorrida a partir das primeiras décadas do século $X X$ é resultado direto dos baixos preços dos terrenos, abandonados por muitos dos imigrantes que chegaram à cidade no final do século XIX. Foto do autor, janeiro de 2009.

Mas voltemos um pouco para compreendermos a origem e o desenvolvimento do núcleo colonial de São Caetano do Sul. No final do século XIX, o governo paulista, com o intuito de substituir a mão-de-obra escrava cada

de enterros de colonos que, em sua grande maioria, aconteciam no cemitério da Consolação, na cidade de São Paulo. "14/04/1878 - No Cemitério da Consolação foi sepultado no quadro dos Anjos grandes $n^{\circ} 1$, sepultura $n^{\circ}$ 77, o cadáver do menor Luis Genari, de 8 anos de idade, falecido anteontem as 7 horas da manhã, em o núcleo de São Caetano, é filho de Genari Luciano e Genari Marcella, colonos italianos, falecido de disinteria conforme atestado do Doutor Epiphanio Lourenço, como tudo consta da certidão passado pelo escrivão do Juizo de Paz da Paróquia do Brás e o sepulte-se como pobre do Rdo. Vigário Eugenio Dias Leite”. (1998: 30) 
vez mais escassa devido as proibições ao tráfico negreiro impostas pelo governo inglês e que resultou, no Brasil, na Lei Eusébio de Queiroz, criou, em 1877, um núcleo colonial na antiga fazendo São Caetano pertencente aos beneditinos. Este núcleo colonial recebeu, em seu início, famílias de imigrantes italianos, como nos aponta Martins, em seu livro "Diário de Fim de Século".

01/07/1877 - Neste Domingo, parte de Gênova (Itália) o vapor Europa, de propriedade de G. B. Lavarello \& Cia., sob o comando do Capitão Vianello, trazendo 98 famílias de imigrantes vênetos para São Paulo, recrutados por Caetano Pinto Jr., que para isso fora contratado pelo governo brasileiro. Parte deles, oriunda de Cappela Maggiore, viria para São Caetano. O Jornal Diário de São Paulo publica a notícia, comentando que "a questão é os homens acomodarem-se entre nós. Convém, portanto, que se dêem providencias no sentido de captar-lhes as bóias graças, fixando-os aqui. (MARTINS, 1998: 17)

Este núcleo colonial, diferentes de outras experiências relacionadas a imigração italiana, dava aos imigrantes o direito a posse da terra. Em certa medida, ao contrário do que se pensa sobre a maioria dos imigrantes italianos, aqueles que colonizaram São Caetano do Sul foram ali estabelecidos para serem produtores de hortifruti, vinhos, pães, com objetivo de abastecer a cidade de São Paulo dos gêneros alimentícios dos quais necessitava. A localização do núcleo, às margens do rio Tamanduateí, facilitava a distribuição dos produtos que iriam abastecer o Mercado Municipal de São Paulo. Em alguns casos, os imigrantes permaneciam no núcleo colonial de São Caetano até serem enviados para fazendas de produção de café no interior do Estado. Porém, este não era o objetivo central do núcleo colonial.

A experiência posta em prática em São Caetano do Sul revela as relações, desde a origem, existentes entre a cidade e o subúrbio. O subúrbio surge em função da cidade e é ao mesmo tempo sua negação. Cabe ao subúrbio executar as funções que não podem mais ser realizadas no interior da cidade em decorrência do processo de expansão urbana acelerada da mesma. Desta maneira, portanto, o subúrbio não precede a cidade ou vice-e-versa. Ao contrário, subúrbio e cidade, no caso de São Caetano do Sul e São Paulo, surgem como realidades interligadas por processos que remetem aos mesmos contextos e que 
diferem apenas em suas funções e significados. Neste sentido, analisar o surgimento do subúrbio e da cidade, no caso de São Caetano do Sul e São Paulo, não podem ser tarefas separadas, pois necessita que se pense a interligação dos processos. Esta especificidade do núcleo colonial de São Caetano vai resultar em outro tipo de desenvolvimento sócio-espacial do lugar, que tem como fundamento a propriedade privada da terra e a mão de obra familiar.

Diferente do que possa aparecer em alguns livros didáticos, a colonização realizada pelos imigrantes italianos foi marcada, muitas vezes, pelo fracasso e pelo excesso de dificuldades que os mesmos tiveram que enfrentar durante as primeiras décadas deste processo. No caso do núcleo de São Caetano do Sul, tais dificuldades podem ser comprovadas pelo elevado número de imigrantes italianos que abandonaram suas terras, dirigindo-se de volta a Itália ou indo para Santa Catarina, onde se formavam, naquele momento, outros núcleos coloniais. Como vimos, muitas das dificuldades estavam relacionadas à ausência de auxílio do poder público no que diz respeito a implantação de hospitais, escolas e até mesmo cemitérios. Esta ausência do poder público e as dificuldades enfrentadas pelos imigrantes resultou em um duplo processo que modificou as relação entre os moradores do subúrbio, bem como a relação dos mesmos com a cidade de São Paulo.

Em primeiro lugar, o surgimento de terras ociosas decorrentes da saída e da morte de muitos colonos, possibilitou o processo de expansão industrial da cidade de São Paulo em direção ao núcleo colonial de São Caetano do Sul. Os baixos preços da terra na região, bem como a presença de certa quantidade de mão-de-obra semi-qualificada foram fatores fundamentais para a ocorrência desta expansão industrial. Entre as principais indústrias que se instalaram naquela região, no início do século $\mathrm{XX}$, destaca-se a fábrica de tecidos de Francisco Matarazzo, imigrante italiano que se destacou na cidade de São Paulo no início do século XX, tornando-se símbolo do desenvolvimento industrial paulista relacionado a este período. 


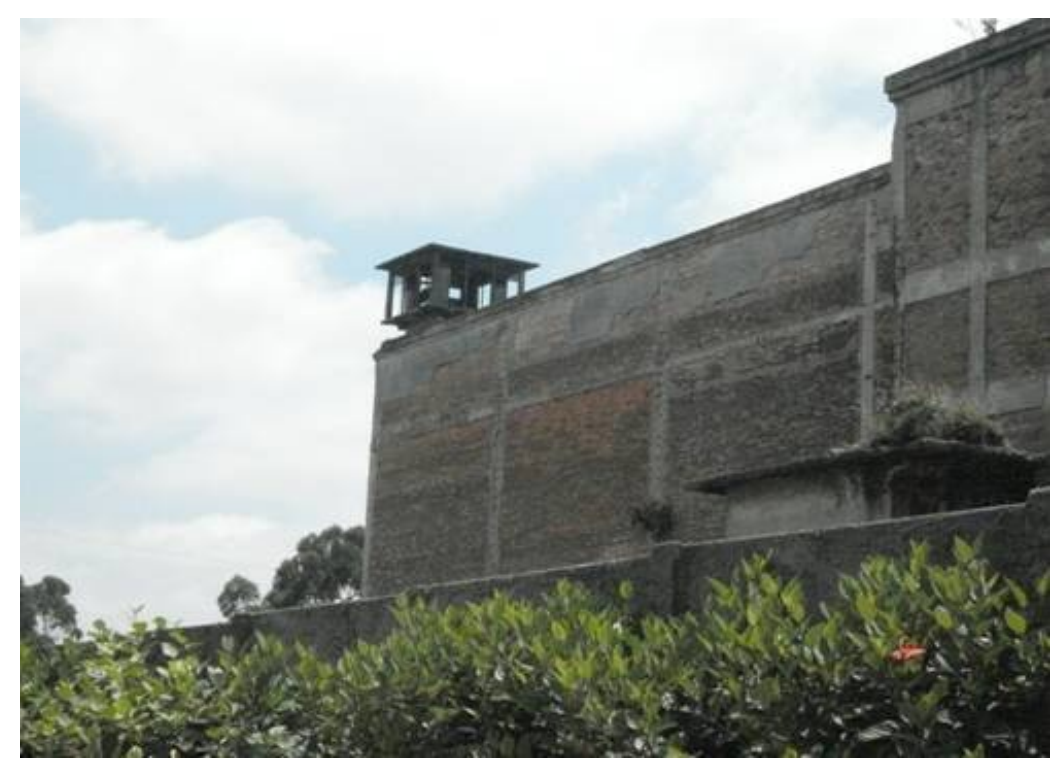

Figura 7: escombros das antigas instalações das Indústrias Matarazzo no bairro Fundação em São Caetano do Sul. Foto do autor, janeiro de 2009.

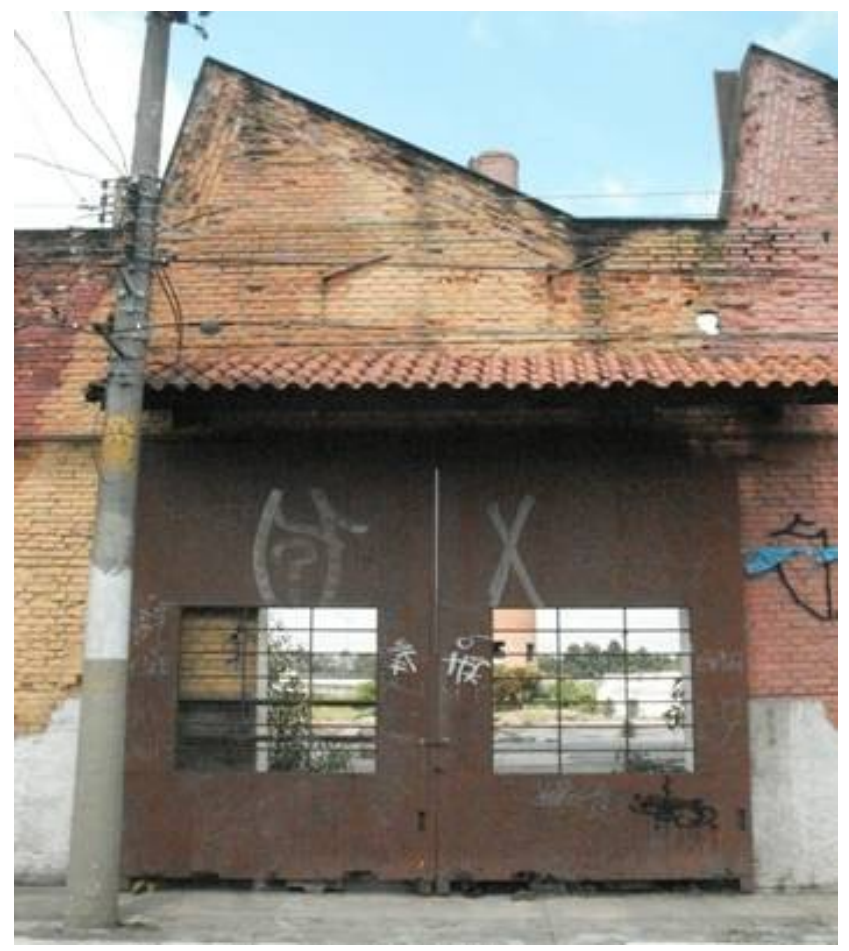




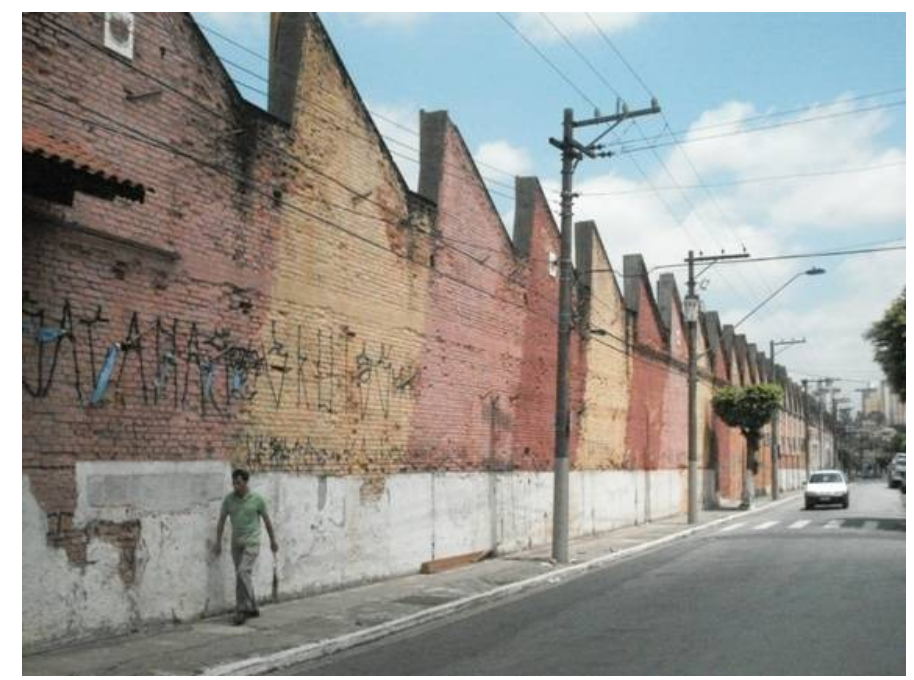

Figura 8: Nestas imagens fica nítido o tamanho do complexo que reunia as atividades das Indústrias Matarazzo. Foto do autor, janeiro de 2009.
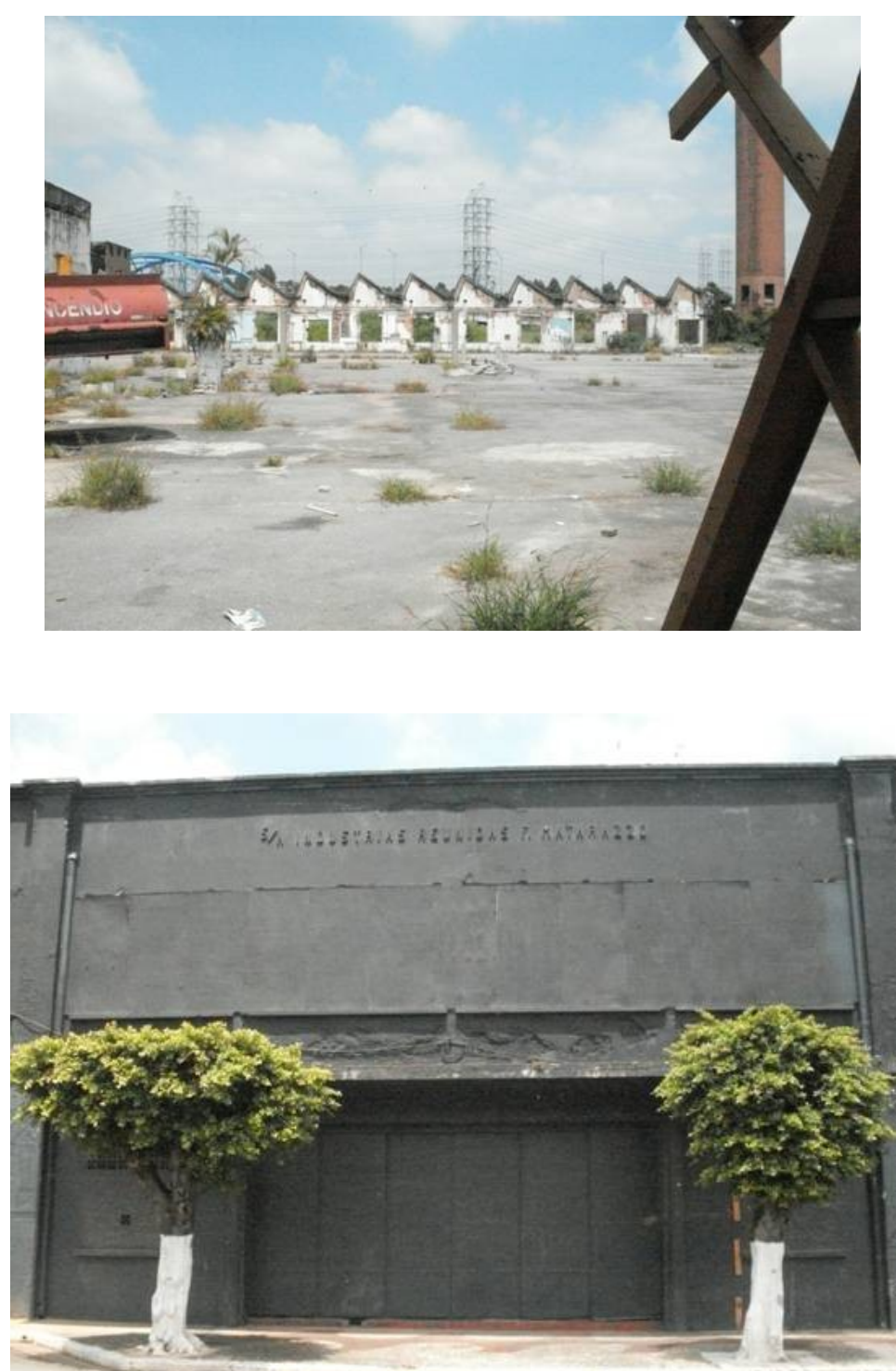

Figura 9: Principal indústria da cidade durante muito tempo, representa a difusão da ideologia do trabalho na cidade, bem como a afirmação da identidade italiana 
em decorrência da origem de seu fundador.

O subúrbio surge, portanto, neste caso, também como o vetor espacial, direção privilegiada para a expansão territorial do capitalismo industrial paulista, reproduzindo a lógica explicitada por Henri Lefebvre entre industrialização e urbanização. A instalação da indústria em São Caetano do Sul recria, em certa medida, o imaginário dos moradores do subúrbio acerca da cidade. Outras relações de trabalho, outras forma sócio-espaciais são introduzidas, alterando, dessa maneira, a relação entre a cidade e o subúrbio que passa a ser agora mediada, principalmente, pela fábrica e pela sua espaço-temporalidade, pelos ritmos sociais que ela impõem.

A instalação das indústrias no Núcleo Colonial de São Caetano agrega um novo elemento nas relações de produção, que seja, o trabalho fabril, regulado pelo ritmo mecânico do relógio. A formação do núcleo colonial de São Caetano se deu, em grande medida, em torno do trabalho familiar livre. Era a família e o trabalho dali decorrente que sustentavam a reprodução da vida no núcleo colonial. Como vimos, as dificuldades encontradas por muitas famílias, que as levou a migrarem para outras partes do Brasil, principalmente Santa Catarina, abriu caminho para que a indústria pudesse avançar sobre as áreas abandonadas. De maneira geral, em uma lógica progressista e linear de pensamento, poderíamos afirmar que este trabalho alienado, produtor de mais valia, ditado pela lógica do capital, destruiria as antigas relações de produção assentadas na propriedade privada e no trabalho familiar. Ao contrário, o que podemos constatar com base em pesquisas históricas, depoimentos já transcritos e na atualidade da dinâmica sócio-espacial do trabalho e das relações sociais em São Caetano do Sul é que há uma permanência do imaginário do trabalho familiar, mesmo que incorporado a lógica do capital, e que é responsável pela sustentação dos laços comunitários que ainda se reproduzem na cidade. Vale lembrar, porém, que tais laços não permeiam toda a cidade, mas dizem respeito a uma parcela da população que se afirma como participantes centrais desta comunidade e que remete seu papel de centralidade a descendência direta dos fundadores do núcleo colonial.

Observemos a seguinte fotografia, retirada de um das entradas das 
Indústrias Francisco Matarazzo:

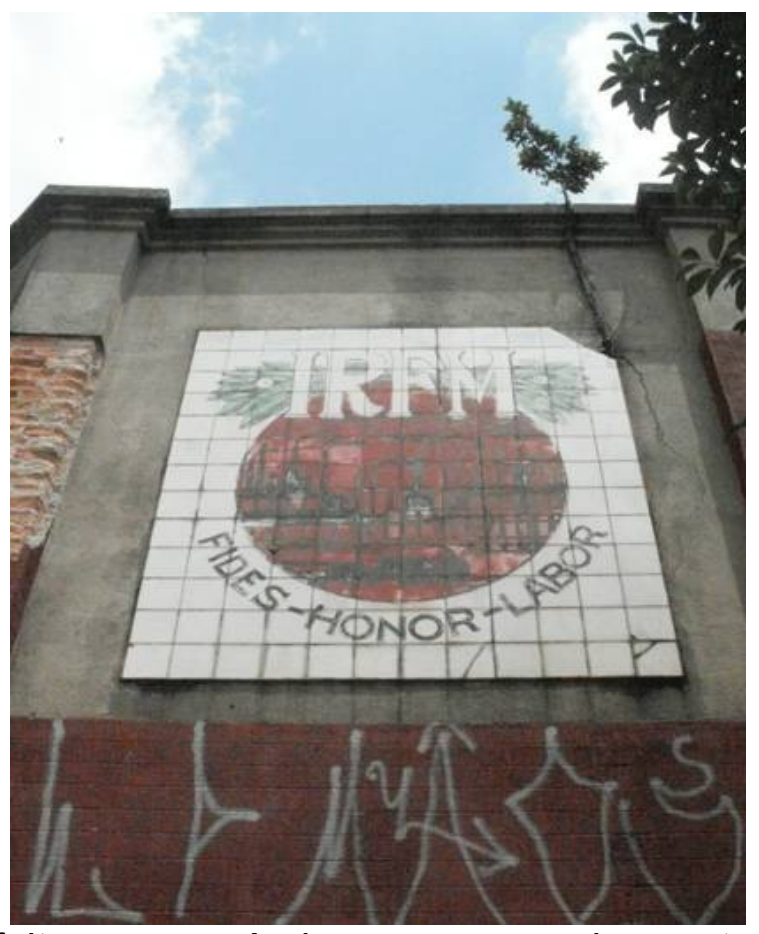

Figura 10: Painel feito em cerâmica em uma das entradas das Indústrias Reunidas Francisco Matarazzo, no Bairro Fundação em São Caetano do Sul. Foto do autor, janeiro de 2009.

Os três elementos (fidelidade, honra e trabalho) estão presentes na vida dos primeiros imigrantes de São Caetano do Sul como fundamentos da sociabilidade que herdaram de um certo contexto rural. Em uma cultura marcada por relações pouco monetarizadas, elementos de cunho subjetivo se tornam os princípios valores que garantem distinção social e reconhecimento. Com o avanço do trabalho industrial, representado pela instalação de grandes fábricas na cidade, tais elementos não são simplesmente esquecidos, devorados pela nova lógica que se quer implantar. São absorvidos como estratégia de controle e de domínio sobre o trabalho do operário. Afirma-se, portanto, uma certa ética do trabalho enquanto positividade, enquanto reprodutor de valores subjetivos que, em certa medida, ocultam as reais condições de exploração dos trabalhadores empreendidas pelos grandes empresários. No subúrbio, portanto, o trabalho industrial, na visão do imigrante italiano, se torna meio para mudança de vida e de enfrentamento das condições encontradas quando do momento da imigração, bem como possibilidade de reprodução de antigas sociabilidades, fundamentos da comunidade da qual fazem parte. 
Para MARTINS, esta leitura acerca do trabalho no subúrbio é um dos principais elementos que tem confundido muitos pesquisadores no que diz respeito à interpretação do subúrbio enquanto um modo de vida, uma forma específica, mais do que uma localização, uma mera situação. Segundo o autor, na memória dos habitantes do subúrbio,

o trabalho não aparece como castigo, mas sim como virtude, mérito e fonte de prazer, algo para deixar a esquerda pequeno-burguesa arrepiada. $O$ prazer do trabalho não destrói os problemas gerados pelo trabalho mal pago. Porque pensar e apreciar o próprio trabalho é algo que o capital pode ter banido da fábrica, mas não conseguiu banir da vida do trabalhador. (MARTINS, 2001:82)

O modo de vida que se constrói em São Caetano do Sul e que, em certa medida, pode definir esta localidade como subúrbio tem o trabalho, visto aqui como positividade, como elemento central a definir as relações cotidianas dos moradores. É a partir de uma certa ética do trabalho, das possibilidades que o mesmo traz no que diz respeito a uma certa ascensão social que os laços comunitários vão se fortalecendo e ganhando outras formas no subúrbio.

Neste sentido, se retomarmos algumas das discussões realizadas no início da nossa dissertação podemos perceber que há aqui um dos elementos propício para se compreender que é a partir das múltiplas sociabilidades que em um determinando momento se entrecruzam que o lugar ganha suas especificidades. O lugar, em São Caetano do Sul, é permeado, portanto, por estas especificidades relacionadas aos múltiplos intercruzamentos das sociabilidades dos imigrantes, tanto aquelas relacionadas ao mundo rural quanto as diretamente ligadas a introdução da lógica do capitalismo industrial. Dessa maneira, desvendar os sentidos e os significados das relações sócio-espaciais que são fundamentos do Lugar em São Caetano do Sul passa, necessariamente, pela compreensão das especificidades que ali se formam. Tais especificidades, por sua vez, são fundamentais para se compreender as relações que tem a escola como lócus de sua realização e que são, ao mesmo tempo, causa e consequência também desta particularidade que o Lugar possui em São Caetano do Sul.

É interessante notar que os grandes movimentos de contestação a esta 
lógica do trabalho que ocorreram na região do $A B C$ surgiram apenas a partir da organização dos sindicatos na segunda metade do século $X X$, com a presença maciça de migrantes nordestinos em sua liderança. As grandes greves das décadas de 1970 e 1980 marcam uma ruptura brutal com esta ética do trabalho dominante, até aquele momento, na região do $A B C$. Há, nesse sentido, a partir destes movimentos de contestação uma ruptura com antigas sociabilidades existentes no subúrbio, porém, sem que as mesmas deixem de existir. Esta ruptura, por sua vez, resulta em uma intensificação dos conflitos e confrontos entre éticas, entre sociabilidades diversas que se apóiam em concepções antagônicas em relação ao trabalho. De um lado, temos a figura do imigrante, principalmente italiano, que vê o trabalho apenas como positividade, como forma de manter os valores e a sociabilidade herdada da terra distante, sendo talvez esta a única coisa que de fato lhe reste. Do outro, o migrante nordestino, inserido na lógica de produção em massa do capitalismo fordista, das grandes linhas de produção das indústrias automobilística, do trabalho cansativo e repetitivo, que vê no trabalho a negatividade de sua alienação. Levadas aos extremos, tais diferenças de concepção resultam em determinadas práticas sócio-espaciais marcadas pela segregação e pela não aceitação do outro como sujeito de um certo lugar. Surge, neste sentido, as estratégias políticas de construção de um discurso histórico-geográfico que tem por objetivo exaltar determinados grupos em detrimento de outros. Cria-se, portanto, o discurso da comunidade, da delimitação de seus participantes e da exclusão de tantos outros que, segundo os ideais valorizados, não possuem as condições mínimas para tal.

Em nossas pesquisas, realizadas a partir de leituras de textos sobre a história local e em conversas com moradores da cidade pudemos constatar que um dos elementos fundamentais responsáveis pela reprodução do ideal de comunidade diz respeito a re-constituição de histórias locais, pautadas em trajetórias pessoais, que, transformadas em histórias oficiais pudessem justificar e legitimar a existência de tal comunidade, delimitando seus participantes e aqueles que não fazem parte. Entendamos melhor este processo.

Segundo MARTINS (1992:13), "na história local e cotidiana estão as circunstâncias da História". No caso de São Caetano, seu desenvolvimento se deu, como vimos, a margem do desenvolvimento da cidade de São Paulo. É na cidade que se passa a história oficial, a história relatada, escrita e difundida por 
todo o país. No subúrbio, a História oficial chega como fragmento, como pedaço irreconhecível do que acontece na cidade. Neste sentido, é negado ao subúrbio participar da história oficial, no sentido em que não the é permitido nela aparecer. $\mathrm{Na}$ história oficial, o subúrbio aparece em poucas páginas, dedicadas talvez a algum acontecimento de relevância secundária. Esta negação da história a qual o subúrbio está submetido, resulta num processo de resistência dos suburbanos, a criação de outra história, que seja, a história vista a partir do subúrbio, a partir do fragmento. Segundo Martins,

A população local se defende contra esse vazio de sentido, essa marginalidade histórica. Os esforços de seus moradores e cronistas são no sentido de dar aos pequenos atos de todos os dias e as biografias esvaídas (e construídas) no trabalho duro de muitas décadas o sentido do épico, do ato monumental dos heróis civilizadores, dos grandes acontecimentos que selam 0 destino das sociedades. (MARTINS, 1992:14)

A história como resistência é também resistência do fragmento, resistência daqueles que buscam na história a afirmação de privilégios em detrimento dos direitos de todos. A história local é a identidade que busca garantir a existência da comunidade, ou melhor, de uma parte dela. Busca, em um determinado passado comum, em um mito fundador, em uma certa narrativa, os elementos, ao mesmo tempo, de identidade e alteridade, que permitam reconhecer os iguais e os diferentes da cidade. Como toda a história, a história local de São Caetano é contada a partir de um ponto de vista, o ponto de vista daqueles que possuem, ou que afirmam possuir, a autoridade para contá-la. Esta autoridade se baseia em outro importante elemento que se quer reproduzir, que seja, a tradição. Aqui se faz necessário uma discussão profunda acerca de alguns elementos anteriormente apontados.

Uma das características principais que aparecem na história local de São Caetano diz respeito e se fundamenta na idéia de comunidade. $O$ que esta idéia representa? Zygmunt Bauman, em livro sobre o assunto, apresenta as implicações desta idéia na atualidade. Para o autor, a idéia de comunidade sempre esteve associada a uma certa positividade, marcada pelo fato de que viver em comunidade é melhor do que suportar a solidão da vida. Para o autor, 
porém, é preciso superar esta visão unilateral acerca da comunidade para que se possa compreender a relação entre o ressurgimento das comunidades e o momento atual do mundo. Para Bauman, existe uma clara diferença entre a comunidade ideal, sempre positiva, e a comunidade realmente existente. Para o autor, a comunidade realmente existente,

exigiria rigorosa obediência em troca dos serviços que presta ou promete prestar. Você quer segurança? Abra mão de sua liberdade, ou pelo menos boa parte dela. Você quer poder confiar? Não confie em ninguém de fora da comunidade. Você quer entendimento mútuo? Não fale com estranhos nem fale línguas estrangeiras. Você quer essa sensação aconchegante de lar? Ponha alarmes em sua porta e câmeras de TV no acesso. Você quer proteção? Não acolha estranhos e abstenha-se de agir de modo esquisito ou de ter pensamentos bizarros. (BAUMAN, 2003: 10)

Participar da comunidade, como vimos, requer aceitar as regras que nela estão postas. Qualquer ação que descontente os participantes de uma determinada comunidade, resulta na perda da proteção que esta lhe garante. Dessa maneira, a comunidade funciona numa relação tênue que tem como principal elemento a definição do "nós" e do "eles". A construção de uma identidade comunitária se faz na definição clara de sua alteridade sendo que nesta relação os dois lados se tornam estigmas, imagens estanques.

No caso de São Caetano do Sul, esta construção da história local como fragmento da história se pautará no desenvolvimento de uma auto-imagem, alicerçada principalmente no ideal de italianidade. Segundo Martins,

Se a religião foi o primeiro elemento de aglutinação, ganhou força muito rapidamente a italianidade. A qual, aliás, não fora real para a maioria dos colonos chegados a São Caetano. A maioria deles nascera antes que se consumasse a unidade nacional italiana, antes que a Itália existisse como tal. A Italianidade foi, portanto, construída na adversidade das condições de vida que o imigrante encontrou no Brasil (MARTINS,1992: 189).

O ideal de italianidade permitiu aos migrantes fundadores do núcleo criarem uma identidade coletiva capaz de fomentar a solidariedade entre o grupo 
e para que assim o mesmo pudesse enfrentar as dificuldades relacionadas às primeiras décadas da colonização. Passadas as primeiras dificuldades, o ideal de italianidade passa a ser retomado no sentido de fomentar a auto-imagem dos grupos tradicionais de São Caetano do Sul com o intuito de marcar a diferença deste grupo em relação aos outros que passavam a compor a estrutura demográfica da região do $A B C$.

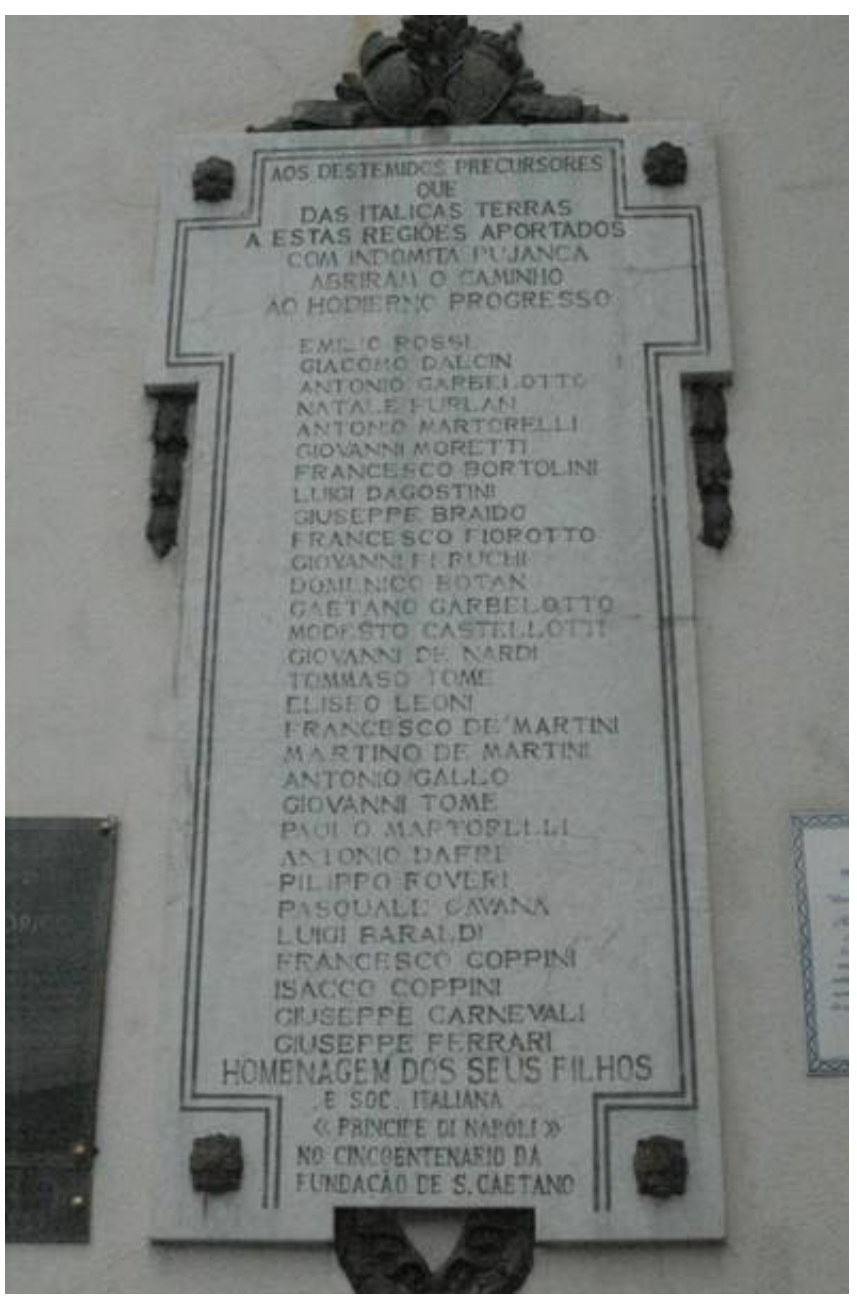

Figura 11: Placa comemorativa em homenagem aos primeiros imigrantes que fundaram São Caetano. A formação do discurso da italianidade se reproduz ao se afirmarem determinados grupos em detrimento de outros, bem como a partir da utilização de conceitos como "moderno" e "progresso". Foto do autor, janeiro de 2009.

Segundo FERES, em seu livro Herdeiros da Fundação, a coesão do grupo dos chamados fundadores da cidade só foi possível a partir de um processo de reconstrução da história local e da substituição, em muitos momentos, da história pelo mito.

A história de São Caetano aparece, pois, como história de 
família. Esta assume o papel principal na história sancaetanense, ocultando outras explicações. Mas é uma história caracteristicamente épica, tributária de marcos memoráveis pela grandiosidade inaugural (FERES, 1998: 136)

Baseada no ideal das famílias fundadoras, a história-mito de São Caetano do Sul oculta mais do que revela. Pouco deixa vir a tona a história das outras famílias, das que vieram e foram embora, no início do núcleo, das que chegaram com a expansão industrial e passaram a ocupar as periferias da cidade e que tiveram negados a própria identidade de pertencentes a cidade. A história de São Caetano do Sul, organizada, escrita e compilada pela e para a reprodução do poder, é a história contada pelos vencedores, por aqueles que vêm na pseudoidéia de fundação constructo estratégico de poder, elemento legitimador de diferenciação.

Para Feres, este processo de construção de história-mito ganha força a partir do processo de expansão das indústrias pelo $A B C$.

Certamente não foi uma mera coincidência que a divulgação dos nomes de chefes de famílias identificados como fundadores tenha se dado em 1927, fazendo parte dos festejos em comemoração ao cinquentenário da fundação do núcleo colonial. As indústrias se expandiam e com ela chegavam as pessoas de fora. Paradoxalmente, a industrialização, que foi modificando a paisagem e o ritmo de vida local, indiretamente induziu a criação do ideal fundador como estratégia de coesão e de defesa dos que aí já se encontravam (FERES, 1998: 137)

A autonomia política, conquistada em 1948, foi uma vitória dos grupos tradicionais de São Caetano do Sul e serviu, em certa medida, para reforçar ainda mais a auto-imagem de tais grupos em relação às outras cidades do $A B C$ e aos outros moradores da cidade. $O$ ideal de italianidade será uma das bases na qual se fundamentará o processo de autonomia política que se desencadeará em São Caetano a partir da década de 1940. No Hino composto em homenagem a autonomia de São Caetano, está presente tal ideal: 
É em tudo quase sempre o maior

Foste obra de heróico imigrante

Que por ti deixou a Pátria distante".

(Trecho do hino de São Caetano do Sul, disponível em www.saocaetanodosul.sp.gov.br)

A figura do imigrante italiano, destemido, que das terras longínquas veio para desenvolver o país, torna-se a peça fundamental do discurso histórico e geográfico que passa a ser constituído pelos grupos tradicionais de São Caetano do Sul. Pertencer a tais grupos significa corroborar com este ideal de italianidade que se constrói a partir do discurso que remonta a própria tentativa de configuração da Itália após o processo de unificação. O ideal de italianidade se constrói, em grande medida, fora da Itália, visto que, o principal produto de exportação italiana entre o final do século XIX e o início do XX foi a mão de obra imigrante. Neste sentido, a italianidade se torna o princípio de diferenciação social no qual se assenta os grupos tradicionais de São Caetano do Sul e é neste princípio que tais grupos buscam as bases de sustentação de uma certa autoridade política que argumentam possuir.

Em livro sobre as relações de poder existentes em uma pequena comunidade no interior da Inglaterra, Nobert Elias realiza uma pesquisa etnográfica, densa e detalhada, buscando desvendar os processos nos quais tais relações se baseavam e sob as quais tal comunidade se reproduzia. No estudo, Elias desenvolve os conceitos de Estabelecidos e Outsiders, que servirá de título para sua obra e que pautará uma série de posteriores estudos etnográficos que tiveram como principal preocupação compreender as relações de poder existentes em um determinado lugar.

Surgido com o intuito de compreender os significados e os fatores da delinquência juvenil na cidade de Winston Parva (nome fictício dado a cidade estudada por Elias), a pesquisa, a partir de seu desenvolvimento, passou a enfrentar outras problemáticas. Ao poucos, Elias foi percebendo que para se compreender os motivos que levavam os jovens a cometerem atos de vandalismo era necessário compreender a imagem que os mesmo tinham de si e como tal auto-imagem estava diretamente relacionada com os estigmas e preconceitos que sofriam dos moradores de outra área da cidade. A partir disso, Elias percebe que o centro da problemática que envolvia os habitantes da cidade de Winston Parva 
e que era a chave para se compreender a delinquência juvenil estava na relação que existia entre os diferentes grupos da cidade.

Tais grupos se caracterizavam por habitarem zonas diferentes de Winston Parva e se relacionarem com os outros habitantes a partir do lugar em que pertenciam. Portanto, era preciso compreender as diferenças existentes entre os habitantes dos dois principais bairros de Winston Parva para que, dessa forma, fosse possível criar uma hipótese capaz de explicar as relações de poder que marcavam as trocas entre os dois grupos sociais.

Diferente do que se possa pensar, Elias descreve em seu livro que os habitantes da Zona 2 e 3 possuíam condições de vida semelhantes. Muitos trabalhavam nas mesmas fábricas e compartilhavam de salários parecidos. Havia, portanto, uma estrutura socioeconômica muito semelhante entre os habitantes dos bairros analisados. Esta semelhança levantou as seguintes questões:

Sendo assim, que é que induzia as pessoas que formavam o primeiro dos dois grupos a se colocarem como uma ordem melhor e superior de seres humanos? Que recursos de poder lhes permitiam afirmar sua superioridade e lançar um estigma sobre os outros, como pessoas de estirpe inferior? (ELIAS, 2000:21)

Segundo Elias, as questões acima levantadas colocaram em xeque uma série de explicações científicas que buscavam compreender as relações de poder principalmente a partir do viés econômico. Segundo este viés, a diferença de poder entre dois grupos sociais se daria única e simplesmente pela diferença de poder econômico (posse de bens materiais) existente entre os diferentes habitantes da cidade. Em Winston Parva, a semelhança das condições de vida dos grupos envolvidos na relação de poder refutava esta idéia. Era preciso, portanto, um olhar mais atento sobre as relações sociais existentes internamente nos grupos estudados para se compreender de que maneira tais relações poderiam ser as causas das diferenças de poder existentes entre os diferentes grupos de habitantes.

A partir disso, Elias inicia um trabalho intenso de pesquisa etnográfica, procurando nas micro-relações as explicações necessárias para compreender as relações de estabelecidos e outsiders em Winston Parva. É com base nesta pesquisa etnográfica que Elias constrói sua teoria explicativa para o fenômeno. 
Segundo o autor, o poder dos moradores da zona 2, que estigmatizavam como inferiores os moradores da zona 3 , resultava de uma maior coerência interna do primeiro grupo. Esta coerência interna era, por sua vez, resultado de uma maior antiguidade do grupo, o primeiro a formar a cidade de Winston Parva. Para os membros deste grupo, a posição de estabelecidos pertencia-Ihes, por direito, por tradição, visto que se tratavam dos fundadores da cidade. Com a chegada, alguns anos mais tarde, dos habitantes que irão formar a zona 3, os habitantes da zona 2 fortaleceram os vínculos de comunidade com o intuito de criar a fronteira necessária para separar o "nós" do "eles". Esta separação se deu, principalmente, em virtude da estigmatização que os estabelecidos criaram para os então chamados outsiders.

Para a construção da estigmatização, o lugar onde foi formado a zona 3 aparece como ponto negativo. A zona 3 é separada da zona 2 pela linha do trem e é conhecida, pejorativamente, pelos habitantes da zona 2 como beco dos ratos. Tratava-se de uma área pantanosa que não foi utilizada quando da criação da zona 2. A própria imagem do pântano, da lama, da sujeira, foi utilizada no processo de estigmatização dos moradores da zona 3.

Um fato importante que Elias descreve em seu livro diz respeito à forma como os moradores da Zona 3 reagem a esse processo a eles direcionados pelos habitantes da Zona 2. Ao invés de contra-atacarem com a produção de uma imagem positiva, aceitam a imagem produzida pelos moradores da zona 2 , transformando-a assim em auto-imagem. E é nesse sentido que a delinquência juvenil, praticada por garotos da zona 3 é a reafirmação da auto-imagem incorporada.

Voltemos agora a São Caetano do Sul. A idéia de trabalhar com os conceitos de estabelecidos e outsider para compreender um pouco melhor as relações sociais existentes entre as pessoas de diferentes lugares da cidade me veio a tona a partir do presenciamento de algumas situações na EME Profa Alcina Dantas Feijão, que lembravam, em certa medida, aquelas descritas por Nobert Elias em seu livro. Um dos elementos mais marcantes que pude presenciar em minha prática cotidiana na escola diz respeito a uma série de estigmatizações que existem nas relações entre os alunos e que estão diretamente ligadas aos bairros onde vivem e as origens das famílias. Assim como existe uma certa exaltação em relação a pertencer a uma família considerada importante politicamente na 
cidade, também real o fato de que morar em determinados bairros e possuir determinada origem familiar resulta em um processo amplo de estigmatização e de preconceito. O que mais me chamava a atenção naquele momento era o fato que a maioria dos alunos agia de forma preconceituosa, reproduzindo os discursos da história oficial da cidade, sem ao menos conhecê-la. Reproduziam um discurso que desconheciam, sem questionar os interesses e estratégias que tais discursos ocultavam.

A construção de uma história ideal, pautada nos elementos trabalho, família e italianidade é, portanto, processo fundamental na compreensão das relações de poder que ocorrem na cidade e que passam a definir, portanto, quem são os estabelecidos e os outsiders. Essa definição também diz respeito ao local onde cada uma destas famílias está inserida e resulta em um processo de preconceito geográfico que surge no discurso dos moradores da cidade. Morar em determinados bairros significa não participar desta história local, não fazer parte dos grupos dos estabelecidos e, portando, ter negado, em certa medida, o direito à cidade. Tais relações, por sua vez, marcam, em certa medida, a sociabilidade encontrada no interior da EME Profa Alcina Dantas Feijão, sendo fundamental um olhar atento e crítico para a sua interpretação.

Ao mesmo tempo, ao se afirmarem os estabelecidos, delimitam-se os outsiders. Em nossos trabalhos de campo, pudemos acompanhar a realidade de alguns bairros situados nos limites de São Caetano do Sul e que são visto pela maioria da população como lugares distantes da realidade do restante da cidade. Vale ressaltar que na fala de muitos de nossos alunos este preconceito geográfico em relação ao bairro de moradia está explicito. Muitos alunos, que moram nestes bairros considerados "inferiores" tem vergonha de se afirmarem moradores de lá. O caso mais explícito diz respeito ao Bairro da Prosperidade, último a ser incorporado à cidade de São Caetano, após o seu processo de autonomia política. No caso do Bairro da Prosperidade, há uma certa repulsa, por parte dos moradores dos outros bairros da cidade, em relação ao mesmo. Para muitos moradores da cidade, o bairro destoa da realidade vivida em São Caetano do Sul. Para outros, a Prosperidade não faz parte da cidade. Reconstruindo o histórico do bairro, pudemos verificar que o mesmo foi incorporado a São Caetano do Sul em 1963, após um plebiscito. Anteriormente, pertencia a cidade de Santo André. Em termos gerais, o bairro é ocupado, em sua maioria, por migrantes nordestinos. É 
no bairro que está situada também parte das instalações da General Motors do Brasil, principal fábrica instalada na cidade e da qual, em certa medida, depende o desenvolvimento econômico de São Caetano do Sul.

O bairro se localiza na várzea do Rio Tamanduateí e faz divisa ao norte com a cidade de Santo André e ao leste com a cidade de São Paulo. Seus moradores, em comparação as condições de vida dos moradores de outros bairros, sofreram e ainda sofrem com os baixos recursos públicos destinados, principalmente no que diz respeito a área de infra-estrutura e combate a enchentes. A linha férrea divide o bairro do restante da cidade e existe apenas uma avenida de ligação. A cidade e o bairro são também separados pelo muro do parque produtivo da GM. As fotos a seguir possibilitam uma melhor compreensão das características urbanas do bairro da Prosperidade.

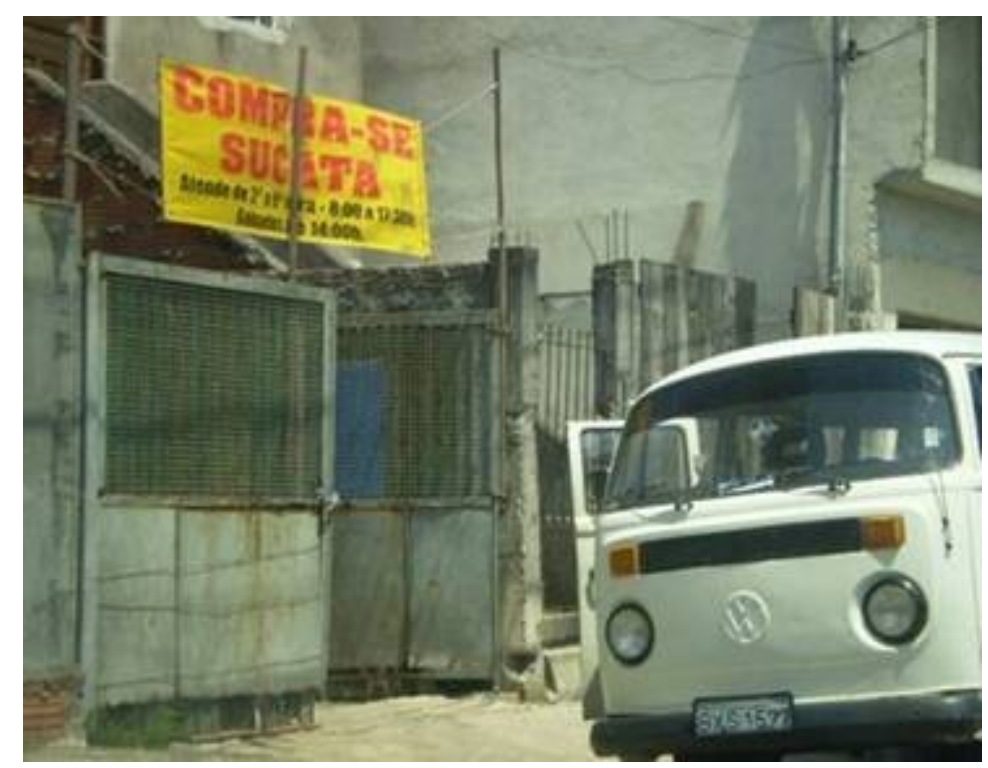

Figura 12: Comércio de Sucata no Bairro da Prosperidade: a proximidade com o parque produtivo de algumas empresas e índice de desemprego favorecem o aparecimento desta atividade. Foto do autor, novembro de 2007. 


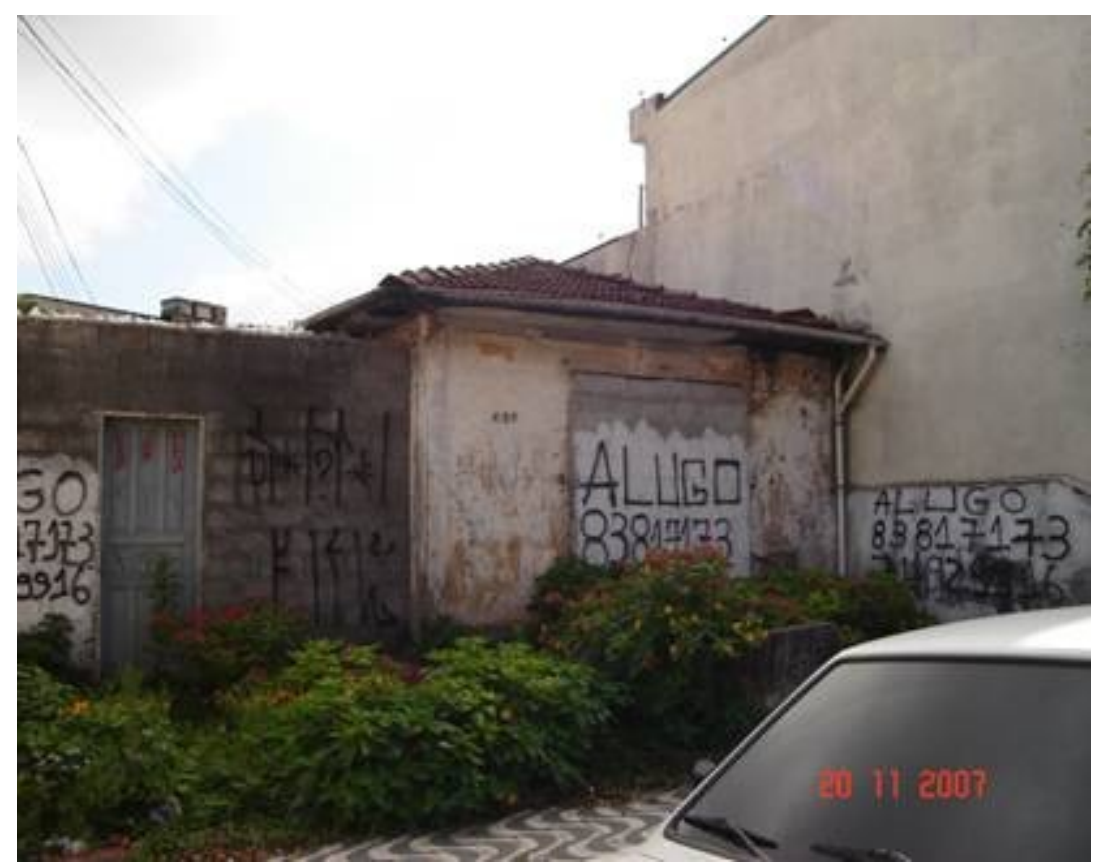

Figura 13: É grande a quantidade de casas no bairro da Prosperidade que estão para alugar. Segundo alguns moradores, isso se dá pelas dificuldades de acesso que os moradores do bairro têm aos serviços oferecidos na cidade. Foto do autor, novembro de 2007.

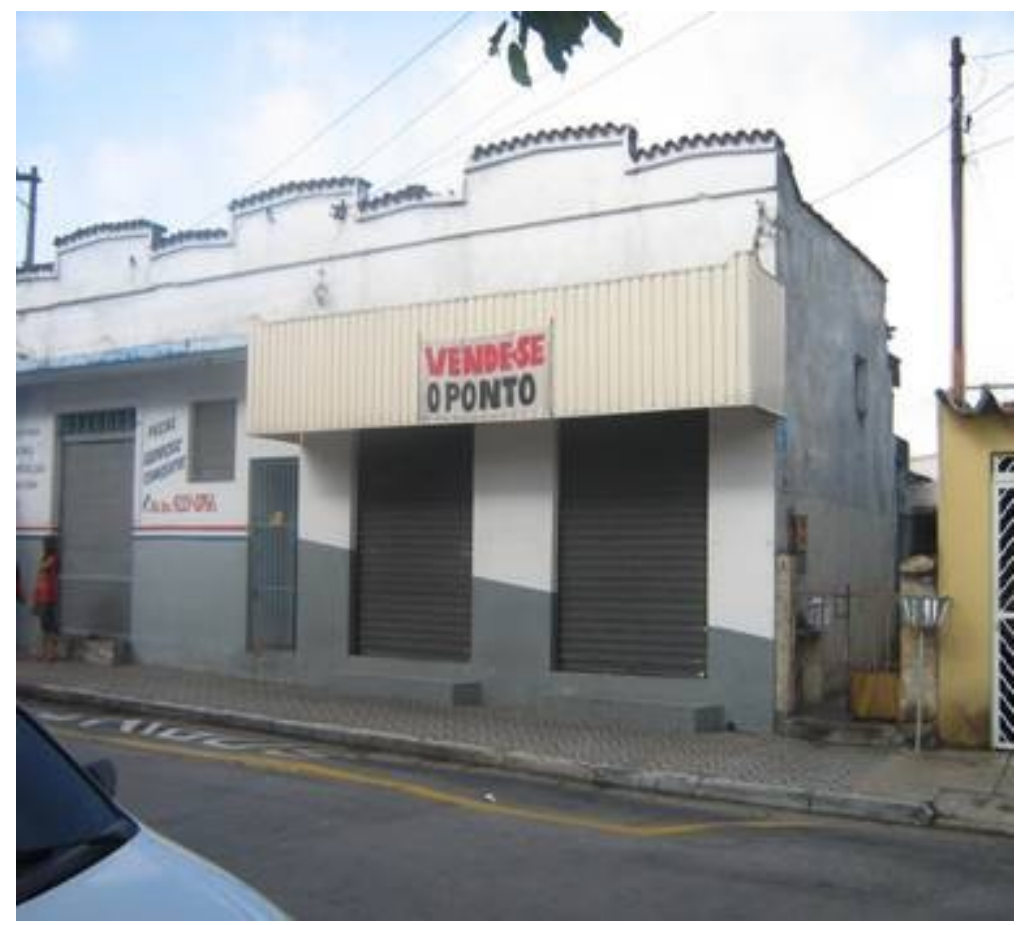

Figura 14: Além disso, pudemos verificar em nossos trabalhos de campos uma série de estabelecimentos fechados, como o fotografado acima. Foto do autor, novembro de 2007. 


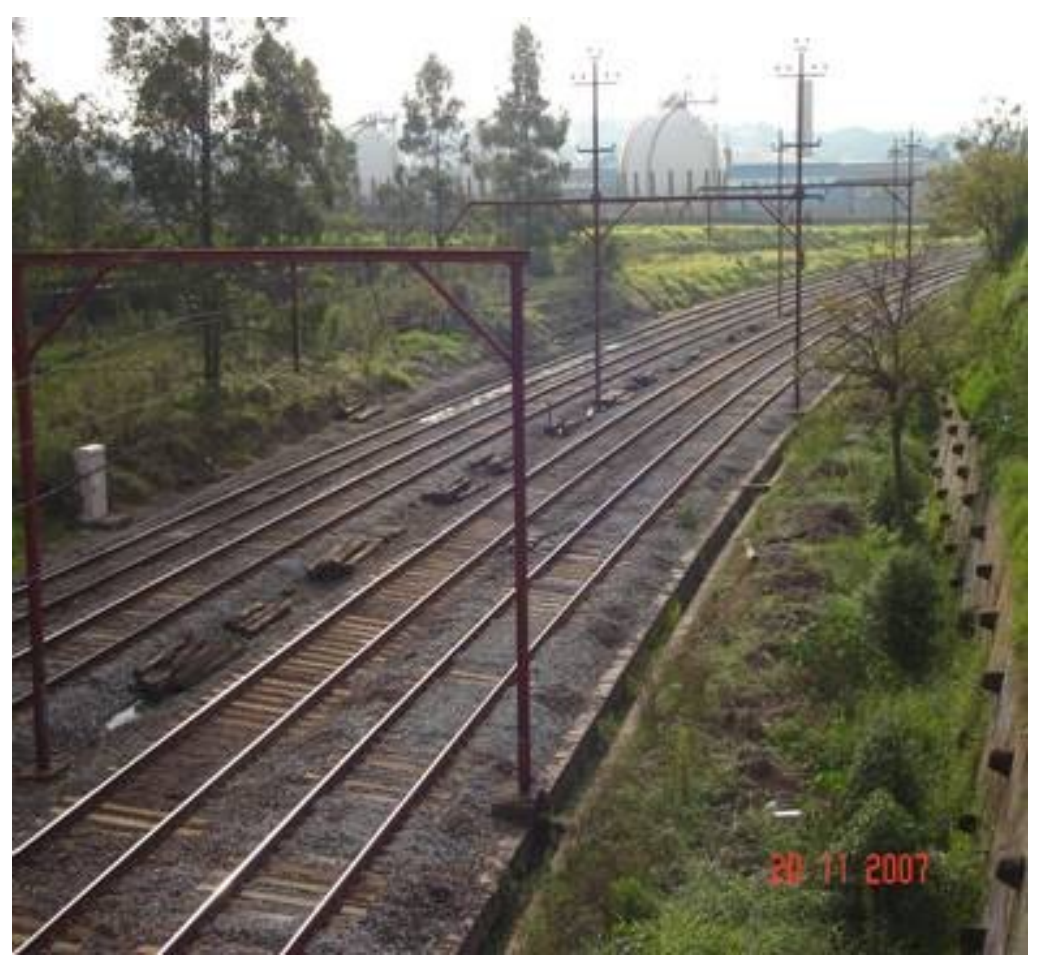

Figura 15: Trecho da Estrada de Ferro Santos-Jundiaí que divide o bairro da prosperidade do restante da cidade de São Caetano do Sul. Foto do autor, novembro de 2007.

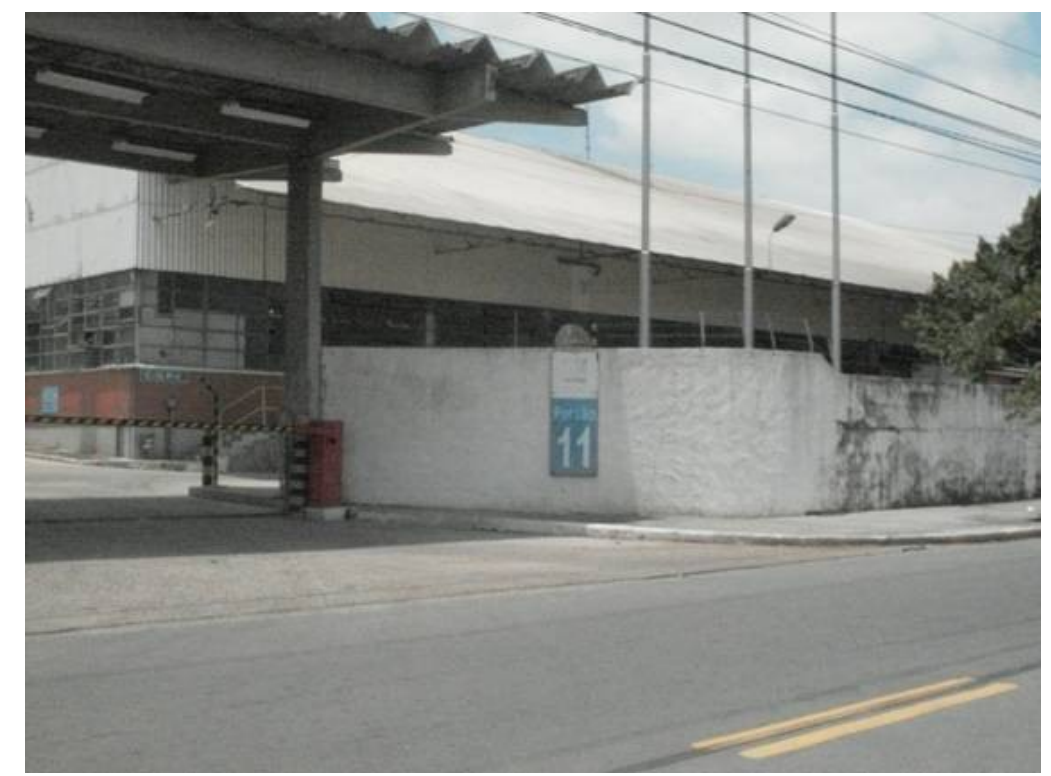

Figura 16: Uns dos inúmeros portão da GM do Brasil no bairro da Prosperidade, em São Caetano do Sul. Foto do autor, janeiro de 2009.

É interessante notar que o Bairro da Prosperidade não fazia parte do território do núcleo colonial original. Dessa forma, não constam entre seus moradores nenhum descendente de famílias que fizeram parte do processo de formação do núcleo colonial. Ao contrário, pudemos perceber em conversas com 
os moradores, realizadas em alguns de nossos trabalhos de campo, que grande parte da população do bairro é de origem nordestina, tendo chegado ao bairro nas últimas cinco décadas do século XX. Esta migração nordestina para o bairro pode ser verificada também pelos elementos espaços-temporais encontrados na paisagem: existem inúmeras casas do norte no bairro.

A Prosperidade é o lugar, portanto, segundo o discurso histórico-geográfico difundido em São Caetano do Sul, daqueles que chegaram depois, atraídos pelas promessas de emprego e de uma vida melhor que o desenvolvimento industrial, pelo menos em discurso, prometia. A própria localização do bairro, no entorno do principal parque industrial da cidade de São Paulo, na área da várzea do rio Tamanduateí, na divisa com o município de Santo André, é também um revelador deste processo de ocupação mais recente do território. No imaginário popular, a Prosperidade é lugar dos outsiders, dos que, na história oficial, não possuem história, não fazem parte dos grandes feitos e obras que marcam os nomes tradicionais da cidade. É, neste sentido, lugar da cidade a ser negado, a ser escondido, a ser apagado dos dados oficiais.

Talvez, estes fatores acima citados, expliquem o fato do bairro da Prosperidade ter recebido os menores investimentos em infra-estrutura urbana de toda a cidade de São Caetano do Sul. A falta de investimentos, por sua vez, resultou em um processo de saída de muitos moradores do bairro em busca de melhores condições de vida, abrindo assim espaço para que muitas indústrias, aproveitando-se dos baixos valores dos terrenos, ali se instalassem. Esta saída dos moradores foi relatada pela edição de 9 de novembro de 1991 do Diário do Grande ABC.

A fuga dos moradores do Bairro da Prosperidade está mudando o perfil do local. As pequenas e microempresas estão tomando o lugar dos $40 \%$ de moradores que já deixaram o local nos últimos 12 anos, segundo avaliação do presidente da SAB, Salvador Martins. Os motivos desta debandada são vários: diminuição do comércio local, falta de segurança, poluição, carência de linhas de ônibus (só duas atendem ao bairro), desvalorização imobiliária e alto índice de doenças infantis. Sem contar as constantes enchentes. (MEDICI, 534: 1993)

Além da chegada de muitas indústrias, houve também um aumento das 
habitações precárias, principalmente de moradores vindos dos bairros situados nos limites entre São Caetano do Sul e São Paulo. Muitos destes moradores acreditam que, apesar das condições precárias de moradia, a mudança para São Caetano do Sul possibilitará uma maior acesso as serviços públicos, principalmente na área de educação e de saúde vizinhos oferecidos pela cidade. São atraídos, portanto, pelo discurso da cidade, pela imagem da cidade ideal que se propaga nos municípios vizinhos. Muitos deste novos moradores não possuem empregos formais, desenvolvendo atividades como catadores de materiais recicláveis.

Com as mudanças ocorridas na política local a partir de 2004, em decorrência da saída do poder da família Tortorello, que há mais de 2 décadas dominava a política em São Caetano do Sul, investimentos começaram a ser feitos no Bairro, o que ajudou a alterar, em certa medida, as condições de vida de seus moradores. Para fomentar o desenvolvimento local, foi criada uma Agência de Desenvolvimento do Bairro, bem como investimentos no combate as enchentes, no campo dos transportes, na reurbanização de praças e na readequação viária. As fotos que se seguem revelam algumas das melhorias que foram realizadas no Bairro nos últimos anos.

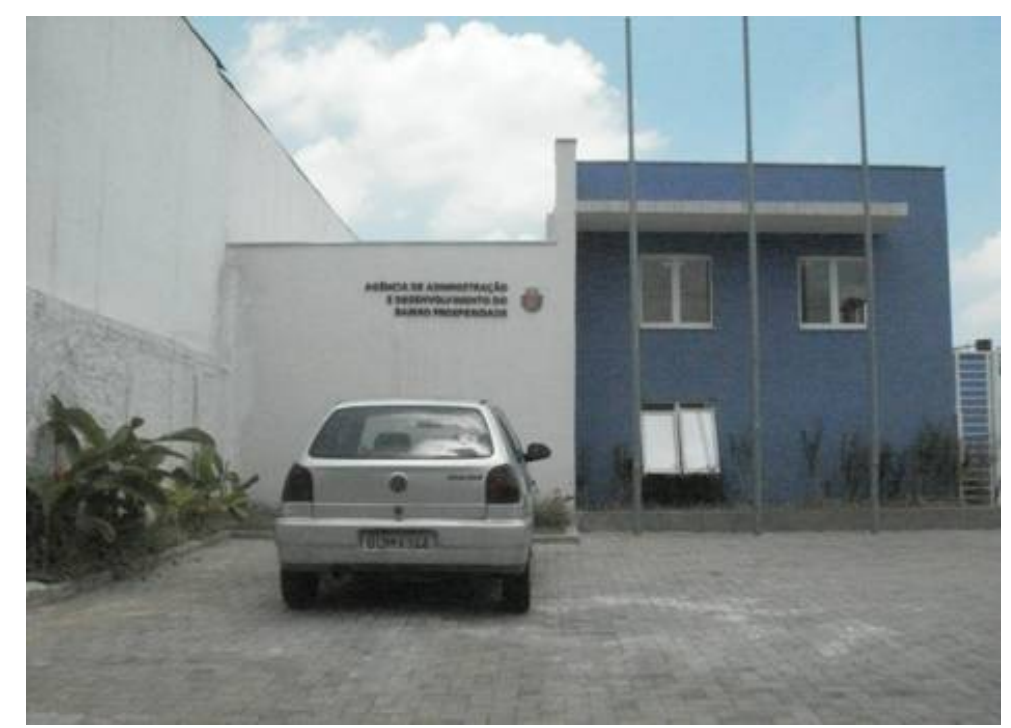

Figura 17: Frente da Agência de Administração e Desenvolvimento da Prosperidade. Foto do autor, janeiro de 2009. 


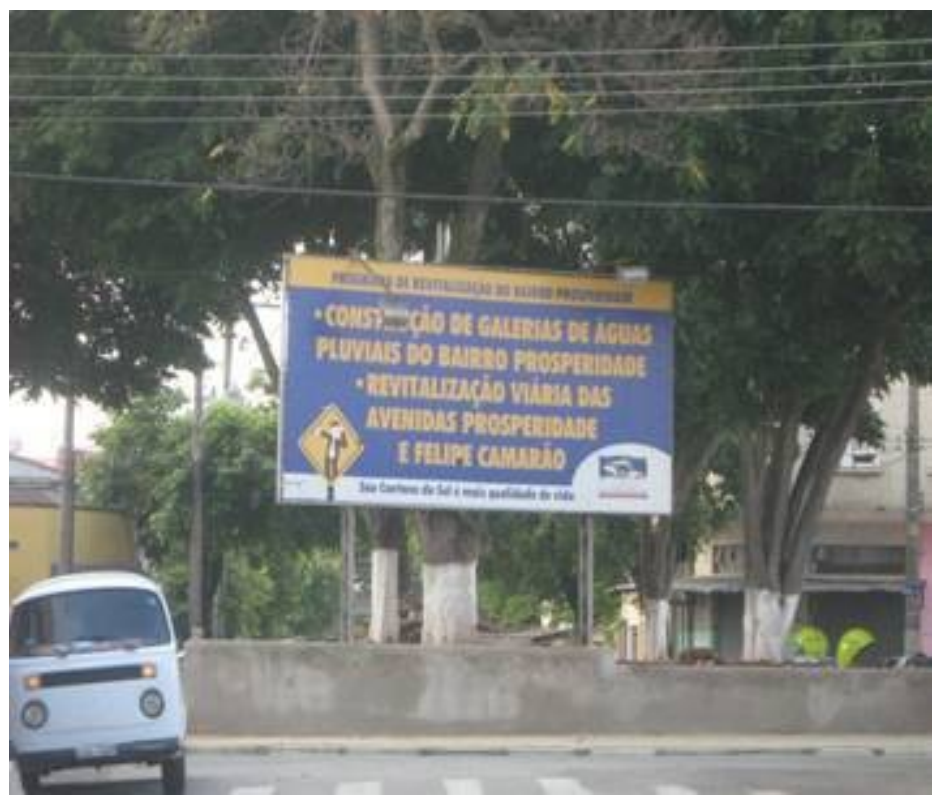

Figura 18: Apenas no ano de 2007, após muita pressão da população do bairro, iniciaram-se as obras de combate as enchentes na Prosperidade. Foto do autor, novembro de 2007.

Existem, porém, outros bairros na cidade de São Caetano do Sul que também não faziam parte do núcleo colonial e que foram incorporados posteriormente. Destaco, como exemplo, o Jardim São Caetano, bairro de classe média alta formado nas últimas 3 décadas, e que é bastante conhecido por abrigar as famílias mais abastadas da cidade. Por que, então, o Jardim São Caetano e seus moradores, não sofrem as mesmas estigmatizações dos moradores da Prosperidade? A resposta está nos significados e funções que o bairro cumpre na configuração espaço-social e no imaginário popular dos habitantes de São Caetano do Sul.

De um lado, o Jardim São Caetano representa, do ponto de vista econômico, uma mudança do perfil de acumulação capitalista na cidade de São Caetano do Sul. A partir do final da década de 1970, a cidade sofreu com a saída do parque produtivo de uma série de indústrias que ocupavam o território da cidade e da região. Neste processo, ocorreu uma transformação do perfil econômico da cidade que até aquele momento dependida da acumulação de capital decorrente da produção industrial. Esta saída dos parques produtivos resultou também em um aumento da emigração de moradores da região para 
cidades do interior de São Paulo e de outros Estados brasileiros. Muitos destes moradores seguiram, em certa medida, o rastro das indústrias que haviam deixado São Caetano e região. Para se ter uma idéia, entre 1980 e 1991, a população de São Caetano do Sul diminuiu em cerca de 10 mil pessoas, o que significa uma parcela importante da população se considerarmos que o número de habitantes da cidade aproxima-se de 140 mil habitantes ${ }^{7}$.

Neste sentido, entre 1980 e 1990, os governantes e empresários locais se viram em uma situação de transformação abrupta do perfil econômico da cidade. Era preciso, urgentemente, traçar estratégias para recuperar o fôlego econômico e para tanto algumas apostas foram feitas. A principal delas dizia respeito a revalorização urbana de algumas áreas e a atração de populações de alta renda para ali residirem. Para tanto, fazia-se necessário a construção de uma nova imagem de cidade que substituísse aquela da cidade industrial, ligada a imagem da General Motors, principal empresa remanescente do processo de saída dos parques industriais. No que consistia, então, esta estratégia? Primeiramente, era necessário mudar o código de zoneamento que impedia a construção de prédios com mais de 6 andares. Esta mudança no zoneamento foi um dos elementos fundamentais para que se pudesse utilizar os terrenos abandonados resultantes da saída dos parques industriais. Nestes terrenos, foram erguidos empreendimentos de alto padrão, calcados no alto valor do metro quadrado da cidade (em torno de $\mathrm{R} \$ 2.200$ ).

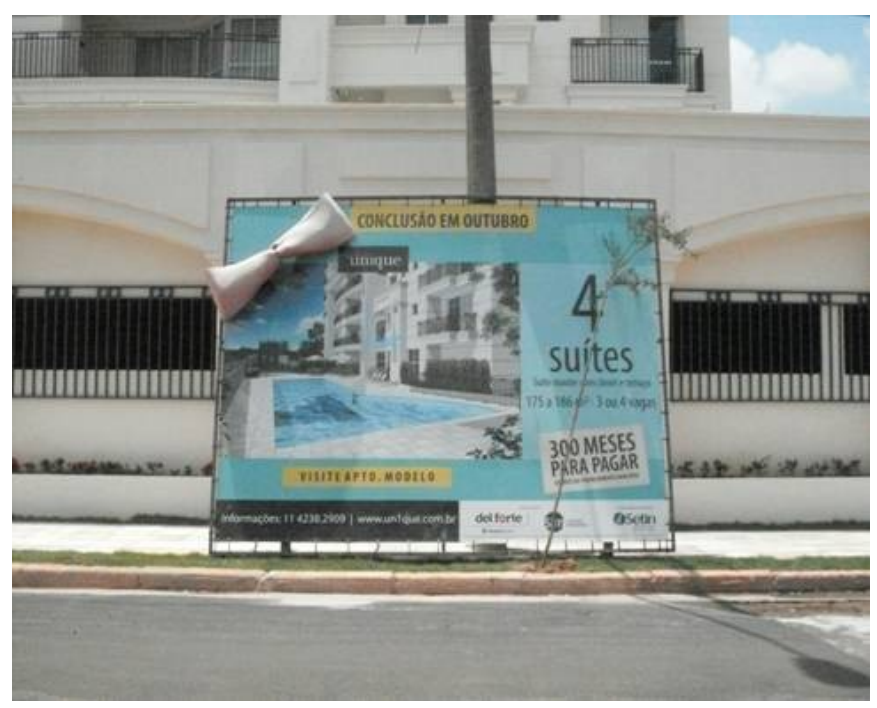

"Segundo o IBGE - Instituto Brasileiro de Geografia e Estatística - São Caetano do Sul perdeu 10 mil moradores entre 1990 e 1996. O decréscimo populacional chegou a 6,3\%. O número de habitantes caiu de 149.519 para 140.007, conforme contagem realizada em 1995”. (MORO JR., 1998:79). 

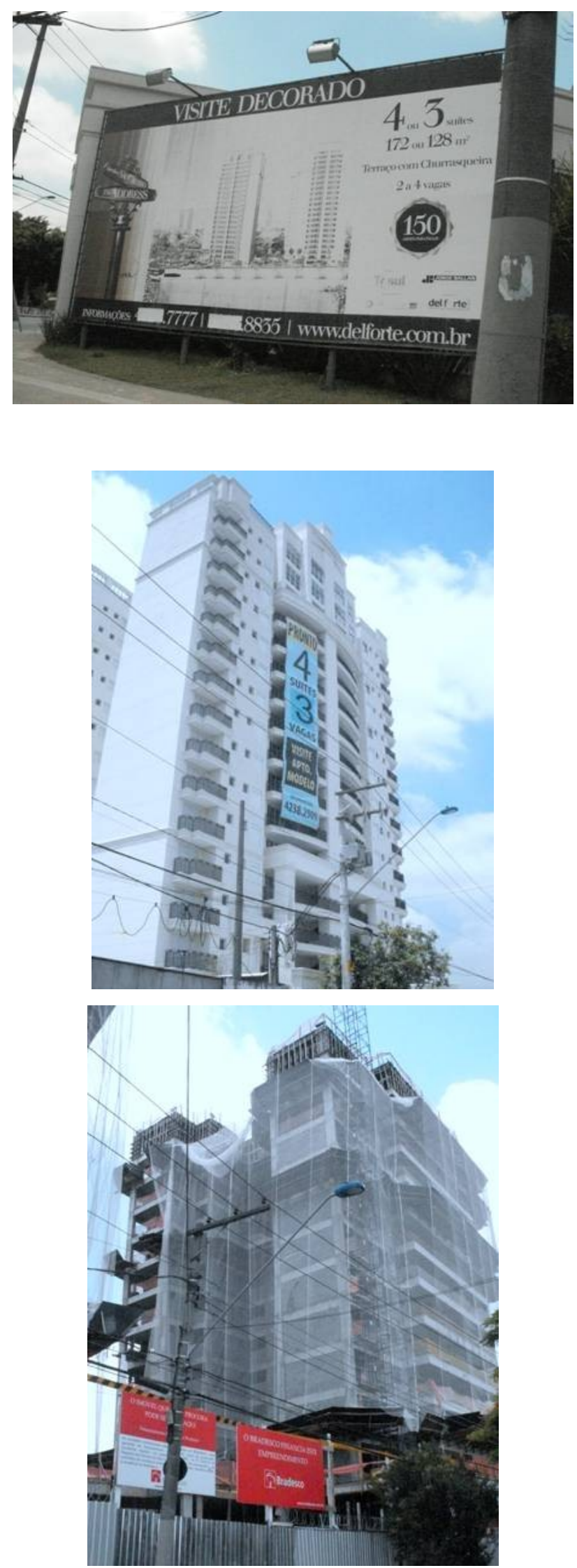

Figura 19: imagens de alguns dos novos empreendimentos urbanos encontrados em São Caetano do Sul. Foto do autor, janeiro de 2009. 
De certa maneira, a construção deste tipo de empreendimento se constituiu também como uma estratégia de seleção dos habitantes que devem residir na cidade. Predominam nos empreendimentos lançados, apartamentos acima de 100 m2 de área privativa, como pudemos verificar nas imagens acima. Tais empreendimentos têm como público alvo as classes de renda $A$ e $B$ que são atraída, por sua vez, pelo discurso da cidade, pautado no elevado padrão de vida e de qualidade sócio-ambiental. Seleciona-se assim os novos moradores da cidade a partir de critérios pautados na lógica do mercado e do consumo, da especulação financeira e da negação do direito à cidade, transformada agora em mercadoria. Como aponta Vainier, os novos planejadores estratégicos são bem claros no que diz respeito a que se destina as novas áreas da cidade, produzida a partir da lógica do planejamento para o mercado:

Não queremos visitantes usuários em geral, e muito menos imigrantes pobres, expulsos dos campos ou de outros países igualmente pobres, queremos visitantes e usuários solventes. (VAINER,2002:80)

Além disso, criou-se um plano para a atração de investimentos no setor terciário de ponta (alta tecnologia, informática) que necessitam de áreas mais reduzidas em relação as industriais e que de certa maneira, poderiam compensar a perda de arrecadação com a saída de algumas industriais. Segundo o Plano Diretor Estratégico de São Caetano do Sul para o período de 2006-2015, todas estas intervenções visam dotar a cidade das condições necessárias para que a mesma possa se inserir e concorrer na atração de investimento no interior da economia globalizada. Percebemos, portanto, que aquilo que almeja alcançar em São Caetano do Sul e que se revela em seu Plano Diretor Estratégico faz parte de um modelo de planejamento que tem se disseminado pelo mundo e que parte do pressuposto a necessidade das cidades de se adequarem para melhor competirem no mercado globalizado. A cidade torna-se, portanto, uma empresa e deve ser administrada como tal para que assim possa alcançar vantagens no processo perverso da economia globalizada. 


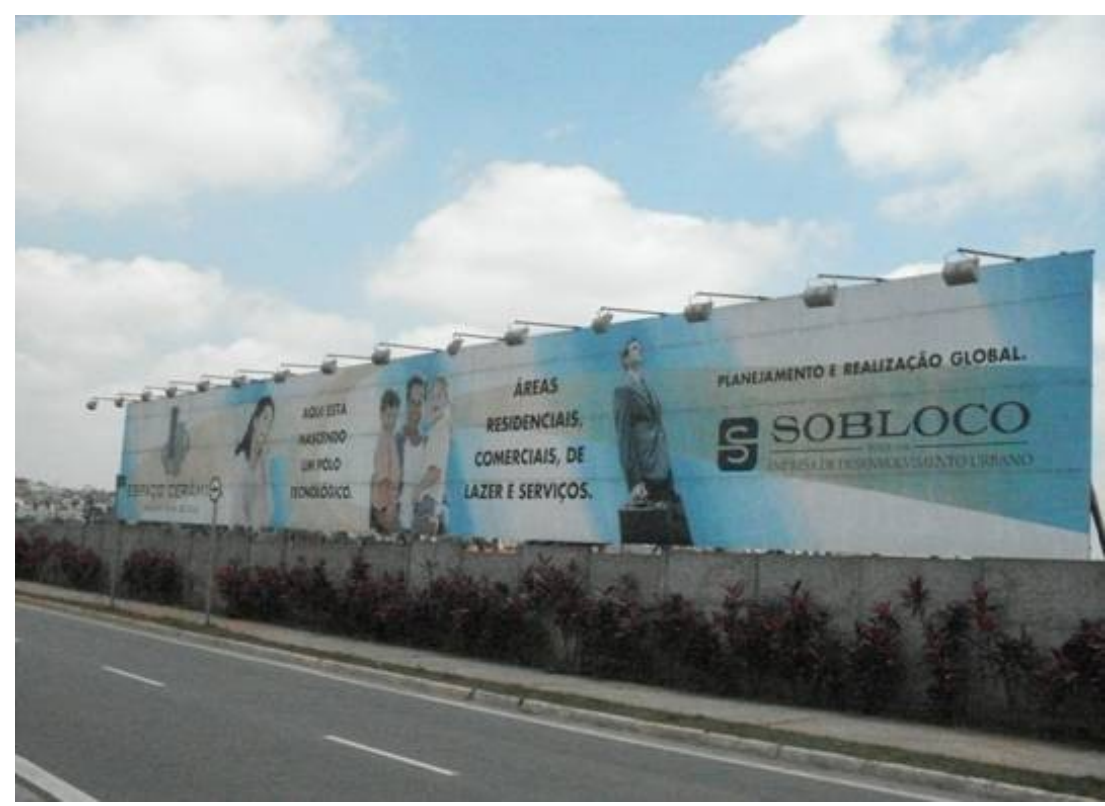

Figura 20: Painel de divulgação do "Espaço Cerâmica", em construção em um terreno antigamente ocupado pela principal indústria ceramista de São Caetano do Sul. O espaço, em concepção, pretende se tornar o maior pólo tecnológico do $A B C$, buscando revalorizar a economia da região e superar a crise inaugurada em decorrência da saída de muitas indústrias da região. Foto do autor, janeiro de 2009.

Porém, esta estratégia de revalorização urbana, de implantação do Plano Diretor Estratégico só poderia se dar com a construção e divulgação de uma imagem da cidade. Quem pagaria tão caro para viver em São Caetano do Sul? O que a cidade teria para oferecer de diferencial para os seus novos habitantes? Cria-se, neste sentido, a imagem da cidade como lugar da qualidade de vida, do urbano para todos, de uma certa democracia plena que ali, de fato, se realiza. Investimentos são realizados na área de educação, saúde, arborização, modernização urbana com o intuito de produzir esta imagem da cidade, que passa a ser diretamente incorporada ao valor dos terrenos. É, porém, uma qualidade de vida restrita, a qual nem todos têm acesso. Os investimentos realizados são destinados a algumas localidades em detrimento de outras. $A$ venda da imagem da cidade se dá a partir do ocultamento da cidade real. Permanecem os problemas de enchente e das precárias condições de vida dos moradores que habitam os inúmeros cortiços da cidade, permanecem a segregação sócio-espacial e todos os problemas dela decorrentes. Enquanto as partes mais valorizadas da cidade, como o Jardim São Caetano, receberam altos investimentos neste processo de revalorização urbana, bairros como a Prosperidade continuaram a sofrer com os problemas de enchente. 
Neste sentido, a aceitação do bairro Jardim São Caetano como parte da história oficial da cidade está no fato de que aqueles que habitam tal bairro, compartilham, direta ou indiretamente, dos ideais e princípios que permeiam o discurso histórico-geográfico do grupo dominante da cidade. Os moradores do bairro se caracterizam em dois grandes grupos: de um lado, filhos das famílias tradicionais de São Caetano do Sul que, após enriqueceram, principalmente em atividades do setor terciário, deslocam-se para o bairro em sinal de demonstração de sua ascensão social; de outro lado, moradores de classe média alta de outras cidades que decidem morar no bairro atraídos pelo discurso urbanístico que a vende como lugar de tranquilidade e qualidade de vida.

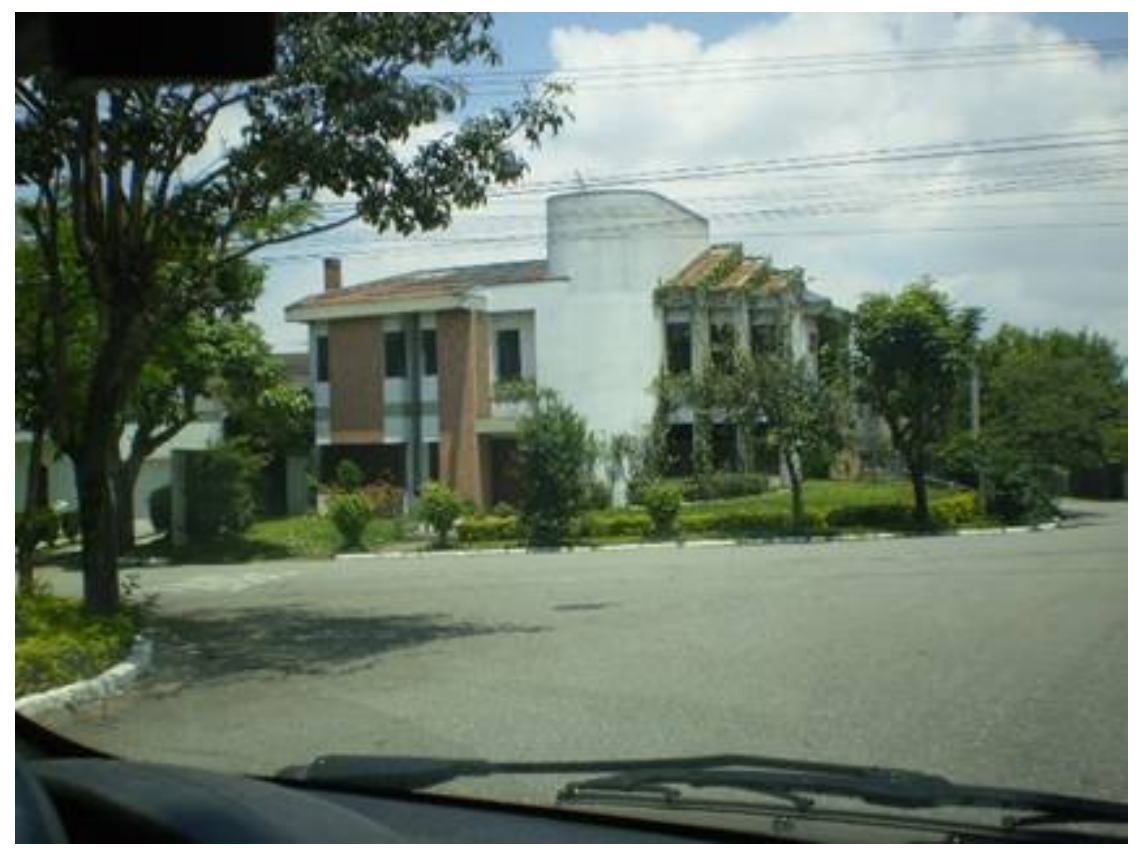

Figura 21: Casa no Bairro Jardim São Caetano: condomínio de rua e vetor de expansão imobiliária. Foto do Autor, novembro de 2007.

O Jardim São Caetano cumpre, portanto, uma dupla função na cidade: é lugar da ascensão social, da mudança de vida e lugar de produção de uma nova imagem da cidade, marcada pelos condomínios fechados, pelas casas de alto padrão, pelos novos empreendimentos imobiliários, pela abertura de um vetor de especulação imobiliária e de revalorização da propriedade sobre antigas áreas de ocupação industrial. É o lugar da imagem da cidade a ser vendida, na lógica de redução da cidade a forma mercadoria.

VAINER (2002) analisa as implicações deste novo modelo de planejamento urbano, decorrente da idéia da cidade-mercadoria, a ser vendida em um mercado 
global e competitivo como uma outra mercadoria qualquer. Esta nova "necessidade" dos planejadores urbanos resulta no desenvolvimento de novas estratégias e perspectivas sobre a cidade que podem ser agrupadas naquilo que se denomina de marketing urbano. Segundo o autor,

Talvez esta seja, hoje, uma das idéias mais populares entre os neoplanejadores urbanos: a cidade é uma mercadoria a ser vendida, num mercado extremamente competitivo, em que as outras cidades também estão à venda. Isto explicaria que o chamado marketing urbano se imponha cada vez mais como uma esfera específica e determinante do processo de planejamento e gestão de cidades. Ao mesmo tempo, aí encontramos as bases para entender o comportamento de muitos prefeitos, que mais parecem vendedores ambulantes que dirigentes políticos" (VAINER, 2002: 78).

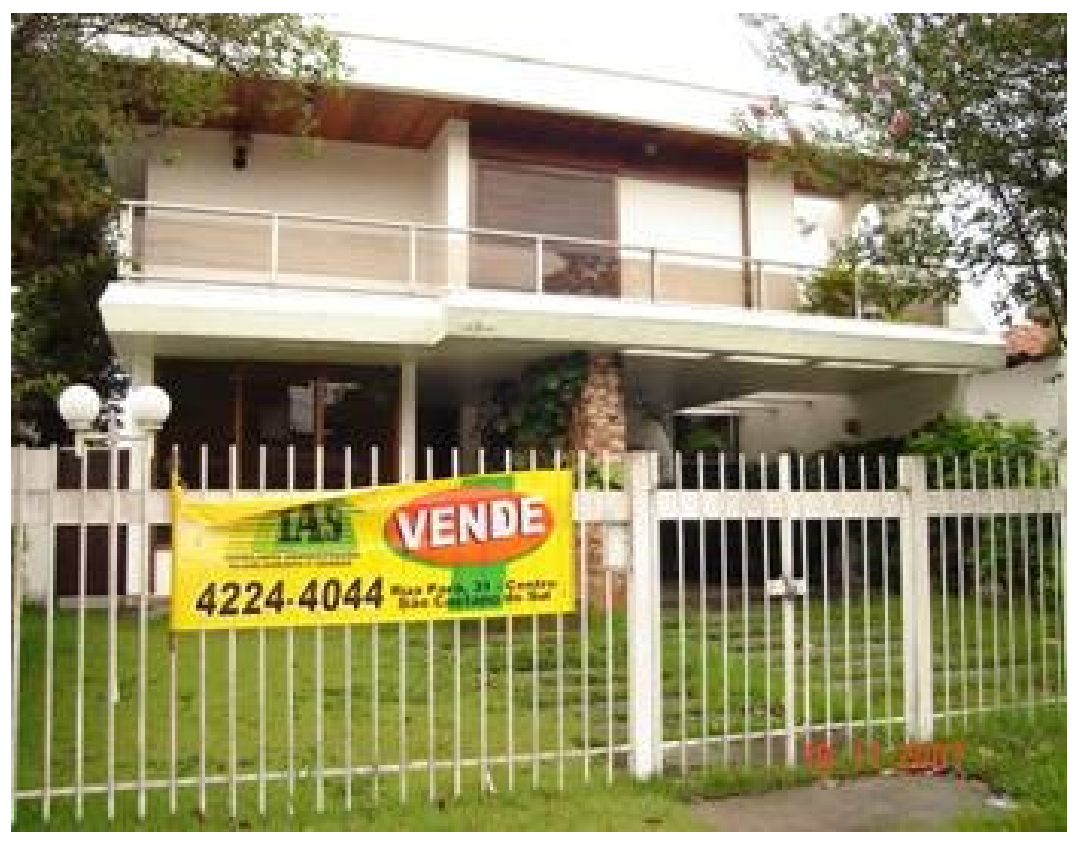

Figura 22: A expansão imobiliária se dá a partir da construção de empreendimentos de alto padrão e que buscam atrair moradores enriquecidos e novos moradores para a cidade. Foto do autor, novembro de 2007. 


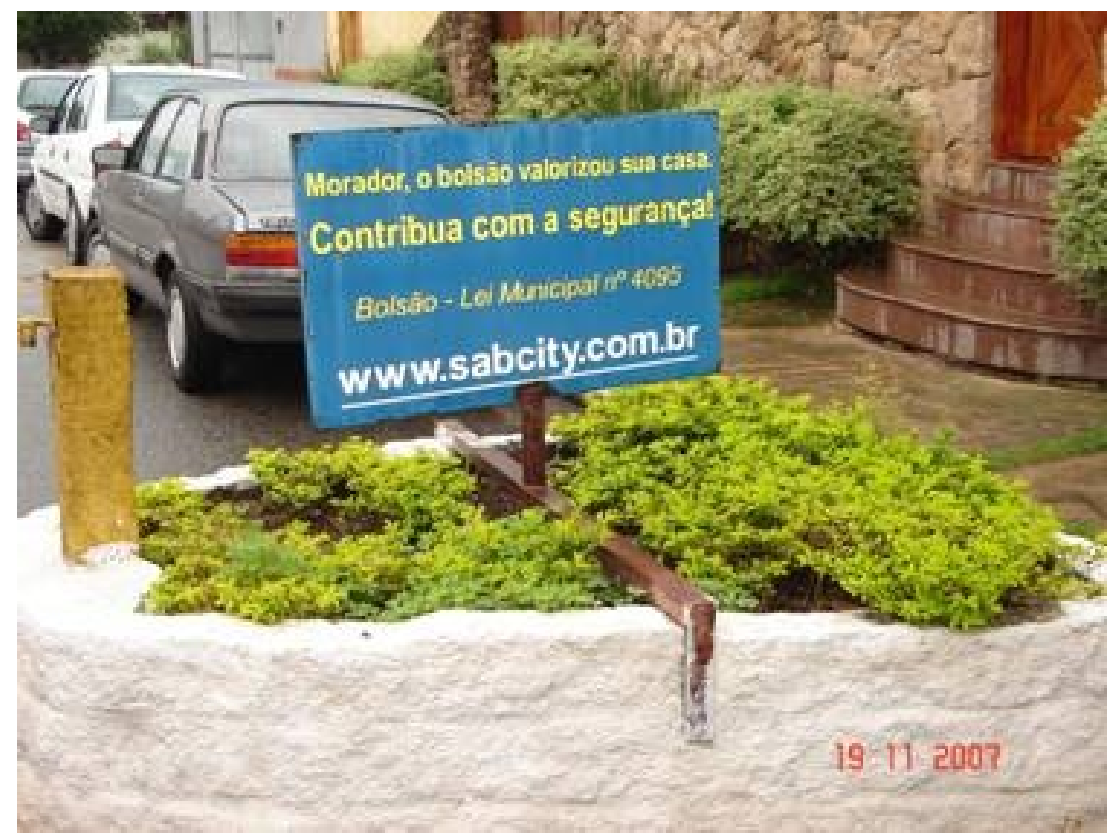

Figura 23: As ruas fechadas são uma das marcam que revelam a privatização do espaço público nesta área de expansão imobiliária representada pelo Jardim São Caetano. Foto do autor, novembro de 2007.

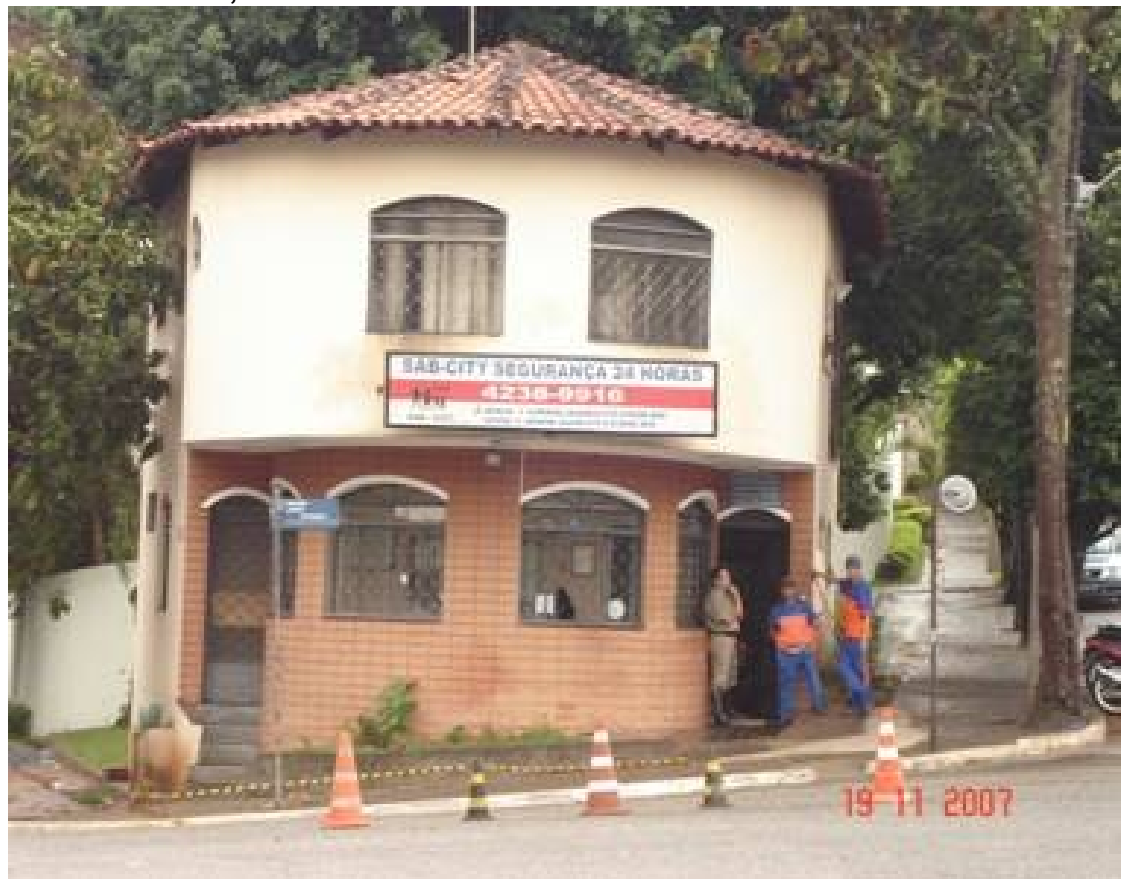

Figura 24: No Jardim São Caetano, a presença do Estado é substituída pela privatização dos serviços públicos. Na foto, detalhe para a guarita de segurança particular, responsável pela vigilância da área nobre do bairro. Foto do autor, novembro de 2007.

Este marketing urbano, para o qual VAINER chama a atenção aparece no discurso oficial dos representantes do planejamento urbano da cidade de São Caetano do Sul. Em sua dissertação de Mestrado, Enio Moro Junior, arquiteto da Prefeitura Municipal de São Caetano do Sul, apresenta o que considera algumas 
estratégias fundamentais para que a cidade possa enfrentar as novas dinâmicas relacionadas a urbanização, principalmente no que diz respeito a transição de cidade industrial para a cidade de serviços especializados. Entre as iniciativas defendidas pelo autor, gostaríamos aqui de destacar duas:

- Renovação urbana: possibilidade de reciclagem de instalações ou áreas tornadas disponíveis pela evasão industrial para a renovação urbana e a implantação/instalação de atividades de alcance subregional e metropolitano.

- Imagem da Cidade: identificação de elementos urbanos característicos que garantam uma identidade visual auxiliando a percepção das singularidades de desenho e imagem da cidade (MORO JR., 1998:134)

Nestes dois trechos descritos acima, fica explícito a estratégia de intervenção urbana em São Caetano do Sul que, em certa medida, e pela própria influência do autor, tem sido posto em prática. De um lado, a abertura de novas frentes de especulação imobiliária aproveitando-se de áreas deixadas pelas indústrias no processo que o autor denomina de evasão industrial. São essas áreas que tem sido utilizada na construção de novos empreendimentos imobiliários de alto padrão, bem como na atração de atividades do setor terciário. Do outro lado, a construção de uma imagem da cidade, que busca ressaltar a singularidade do desenho. O realce da singularidade significa, por sua vez, ocultar as disparidades, as desigualdades sócio-espaciais que marcam a urbanização de São Caetano do Sul e todo o processo de urbanização sob a lógica do capital.

Ao mesmo tempo, a imagem da cidade é um dos elementos fundamentais para se compreender a difusão do discurso histórico-geográfico presente em São Caetano do Sul. Como representantes dos interesses ligados ao processo de revalorização urbana de São Caetano do Sul, muitos dos grupos tradicionais da cidade incorporam tal discurso a imagem nova da cidade que se quer produzir. $O$ passado torna-se, portanto, justificativa e legitimação do presente, bem como garantia de futuro para os que ali escolherão morar. Nesse caso, como nos aponta Bauman, na invenção de uma tradição

O que importa são o presente e o futuro comuns; a única importância de um passado comum é modelar o presente e 
o futuro e manter o curso com um pouco mais de facilidade. (BAUMAN, 2000:137)

Dessa maneira, construir uma imagem da cidade significa, ao mesmo tempo, ressaltar traços a serem lembrados, ocultar o que precisa ser esquecido. $A$ imagem da cidade, a ser vendida, local, regional, nacional e globalmente, é uma marca do planejamento urbano na atualidade e pode ser verificada nas estratégias espaciais que têm sido colocadas em práticas na cidade de São Caetano do Sul. Vale, portanto, retomar a questão feita por VAINER em seu texto: "o que é que, afinal de contas, se vende quando se põe a venda uma cidade?" (VAINER, 2002: 78)

No caso de São Caetano vende-se a cidade ideal, sem problemas urbanos, marcada pela qualidade de vida sócio-ambiental, pelos elevados índices de IDH. Vende-se a cidade sem favelas, sem periferia, no qual o direito à cidade, pelo menos em discurso, está a todos garantidos. Vende-se a imagem de alguns bairros, de algumas famílias; ocultam-se, porém, tantas outras que, por vários motivos, não devem fazer parte deste marketing urbano que se quer construir.

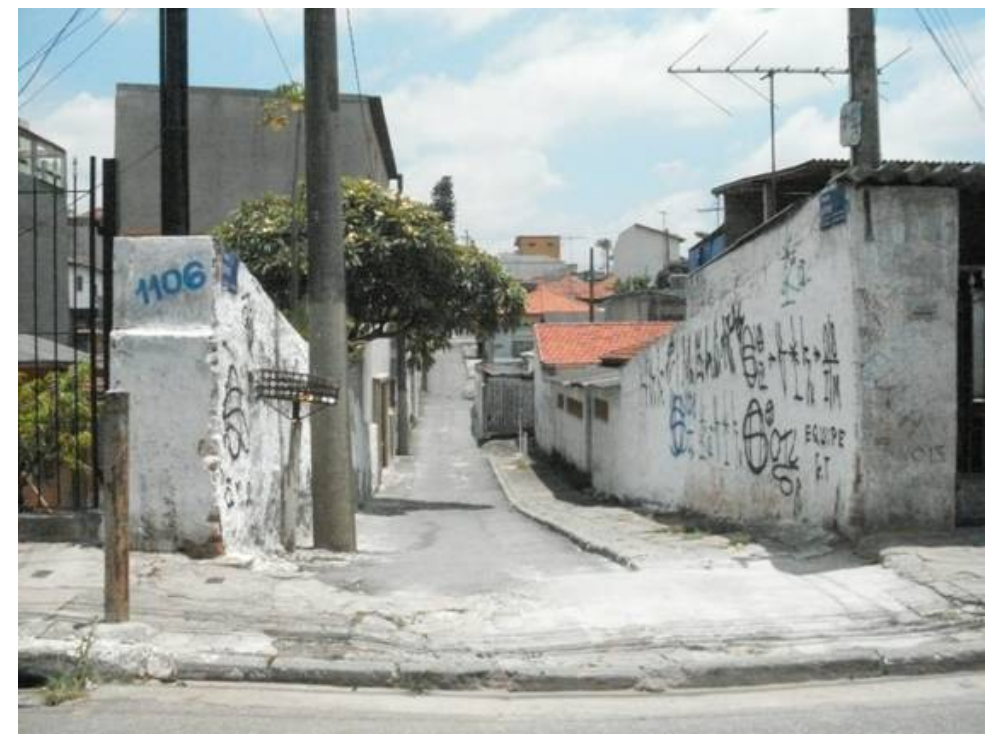

Figura 25 : Rua Sílvia, marcada pela presença de muitos cortiços no qual, em média, 3 a 4 pessoas ocupam um cômodo. Foto do autor, janeiro de 2009 . 


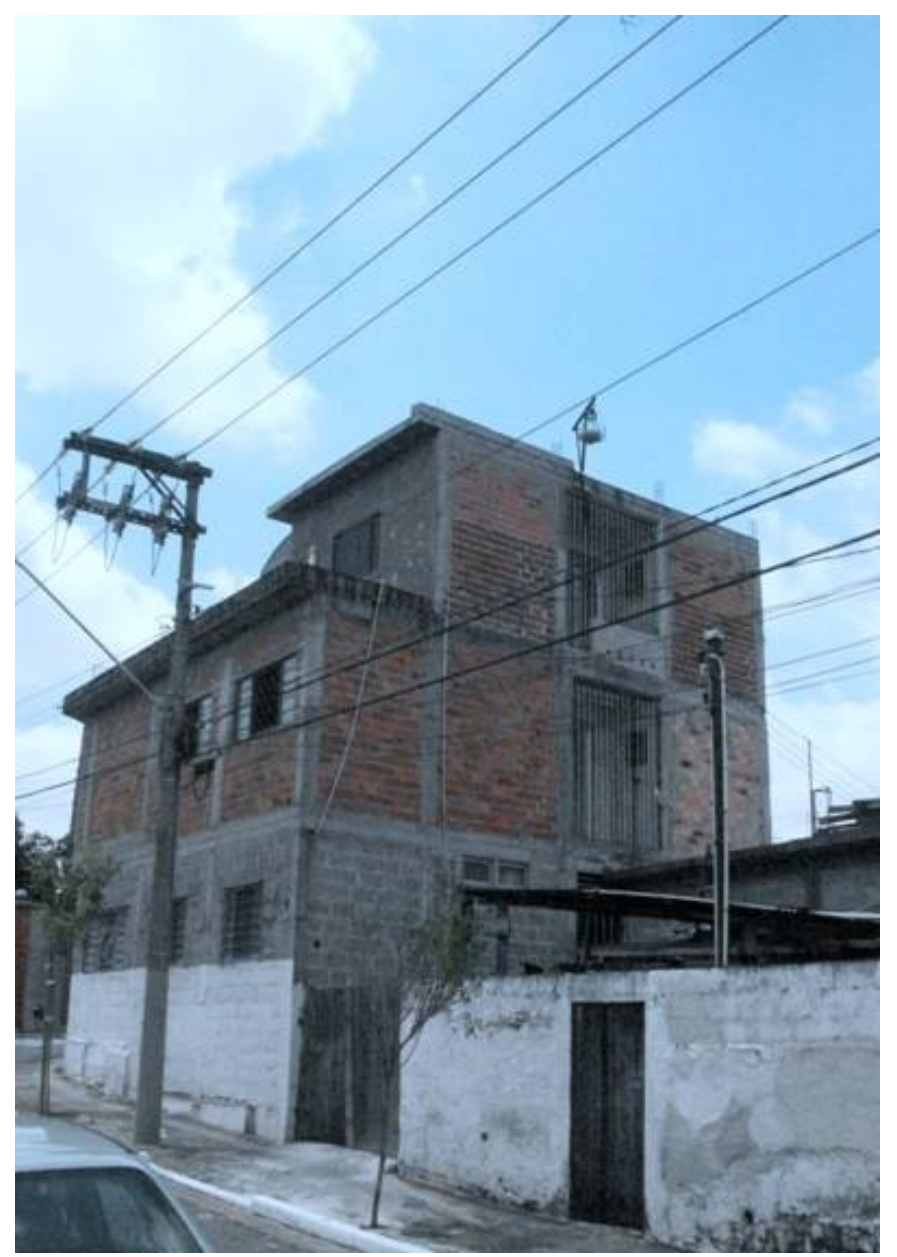

Figura 26: Exemplo de autoconstrução verificado no bairro São José que faz divisa com a favela de Heliópolis em São Paulo. Elementos da periferia há alguns metros da prefeitura de São Caetano do Sul. Foto do autor, janeiro de 2009.

Foi a partir de tais situações que passei a questionar, na pesquisa e em minha prática cotidiana, a maneira como a escola como um todo e a disciplina geografia, lidavam com as questões do lugar. Em certa medida, buscava compreender de que maneira tais discussões permeavam o projeto políticopedagógico da escola, bem como as articulações feitas entre diferentes disciplinas como vistas a fomentar um debate mais amplo acerca das problemáticas locas e suas implicações em outras escalas político-geográficas.

A partir desta problemática, passei a analisar alguns dos elementos que definem as práticas político-pedagógicas no interior da EME Profa Alcina Dantas Feijão e que, em minha perspectiva, são também resultados das dinâmicas políticas presentes na cidade, com o objetivo de compreender as formas como a escola trabalhava ou não com as questões referentes ao lugar. 


\subsection{Do silêncio ao desvelamento}

Ao assumir as aulas no Alcina, lembro-me bem da sensação de estranhamento que tive a primeira vez que entrei na sala dos professores. No período da manhã, são cerca de trinta professores que se reúnem na hora da entrada, do intervalo e, rapidamente, na saída. Observando as conversas e as relações que ali se estabeleciam, percebi que poucas delas versavam sobre reclamações referentes a problemas enfrentados na educação em diferentes lugares: salários, infra-estrutura, relação professores-direção. Senti-me feliz porque a primeira impressão é a de que se ali tais assuntos não se discutiam é porque tais problemas não existiam naquele lugar. Infelizmente, pouco tempo depois descobri que aquela primeira impressão era a projeção de um professor que espera que sua profissão seja definitivamente reconhecida e respeitada.

Por que, então, tais assuntos não se discutiam abertamente naquela sala? Foi a partir desta pergunta que comecei a compreender as relações que existiam entre a escola e lugar, tendo como pano de fundo minhas práticas profissionais como professor.

Diferente de algumas outras redes de ensino, não existe concurso público para os cargos de diretor, assistente de direção e coordenador pedagógico na rede municipal de ensino de São Caetano do Sul. Tais cargos são considerados de confiança e de indicação direta do próprio prefeito, com interferência direta de vereadores e de figuras importantes nos quadros políticos da cidade. A cada mudança de mandato, muda-se o diretor e sua equipe de trabalho, ficando assim os professores e os alunos a mercê da direção que seguem os ventos políticos na cidade. O Alcina, por se tratar de uma escola tradicionalmente importante na cidade, possui os cargos, na área de educação, mais cobiçados pelos aliados políticos de todo prefeito eleito. É no Alcina, portanto, que se revelam também às relações de poder que perpassam a política em São Caetano do Sul.

Segundo uma das professoras do Alcina, há mais de 16 anos na escola e com qual obtive algumas informações sobre a estrutura política na qual está inserida a escola, o sobrenome e o apadrinhamento político são os elementos fundamentais que definem quem será designado para ocupar um determinado cargo. No período que compreende o desenvolvimento desta pesquisa, direção e assistente de direção eram ocupados, respectivamente, por membros das famílias 
Fiorotti e Braido, famílias estas que estão entre o grupo de fundadoras do núcleo colonial e que há décadas exercem importante papel político na cidade. Para o prefeito, é fundamental ter tais famílias como aliados políticos, principalmente pelo fato de poder usar a tradição das mesmas, ratificada muitas vezes no discurso histórico-geográfico dominante na cidade, como uma das estratégias políticas préeleição.

Para quem está acostumado com o horário político na televisão e no rádio, com os outdoors e todas as caríssimas campanhas de marketing que marcam os períodos eleitorais nas grandes metrópoles, soa estranho que a campanha política, em uma cidade há menos de 20 quilômetros do centro da maior cidade do país, aconteça, principalmente, a partir do tradicional boca-a-boca. Porém, o contexto urbano de São Caetano do Sul propicia que tal fenômeno ocorra. E é exatamente esta particularidade encontrada na cidade que ajuda a explicar a relação existente entre os políticos locais e as famílias tradicionais da cidade. Em uma articulação política e estratégica, os candidatos se apóiam na autoridade que os moradores de São Caetano do Sul reconhecem nestas famílias, principalmente pelo discurso que os remete a idéia de fundação e de progresso da cidade, para legitimarem seus discursos e práticas que, muitas vezes, ocultam os interesses particulares que ali existem. Em certa medida, a construção de uma história local pautada nas histórias da famílias fundadoras foi apropriado e articulado em uma estratégia de reprodução dos poderes políticos na cidade.

Durante os primeiros anos em que lecionei no Alcina, como disse anteriormente, foi frequente presenciar a ida de políticos locais na escola e nos eventos por ela organizada. Durante o ano eleitoral de 2008, o prefeito esteve três vezes na escola para anunciar propostas e inaugurar obras. O presidente da Câmara compareceu mais vezes: foram seis ao total, contabilizando almoços e confraternizações. Todos estes elementos iam, aos poucos, revelando-me o significado político e social da escola em sua relação com o lugar.

Porém, o que mais me intrigava era saber como deveria ser minha atuação, como professor de geografia, naquele determinado contexto? Havia tanto a se explorar e tantos riscos a correr. Sabia que uma interpretação crítica das relações de poder e das estratégias políticas que tinham na escola um dos seus lócus de realização poderia me custar o cargo. Comentava com os outros professores sobre este meu incomodo e era, na maioria das vezes, aconselhado 
a esquecer isto e seguir o programa.

O programa estava pautado na adoção de uma apostila, do grupo educacional Sigma, que deveria ser seguida por alunos e professores. Tal apostila havia sido implantada na atual gestão municipal, sendo uma escolha direta da diretora da escola. Como toda e qualquer apostila, tratava-se de um material conteudístico, repleto de erros, com nenhuma preocupação de contextualização do conhecimento.

Apesar de inúmeras reclamações, a apostila foi mantida como principal ferramenta de ensino. Em uma de suas falas, durante o conselho de classe, a diretora da escola atribuiu o desempenho dos alunos nos vestibulares a adoção do sistema apostilado. Para outra professora, porém, em conversa informal, a adoção da apostila está relacionada a um esquema de favorecimento de familiares no qual estão envolvidos membros da direção da escola.

O que nos interessa, porém, é compreender qual o significado da adoção da apostila do ponto das relações sócio-espaciais que ocorrem na escola e no lugar? No caso do Alcina, a apostila é reveladora de uma certa negação do lugar, visto que o mesmo não surge como objeto de pesquisa, como elemento a ser desvendado, repleto de conflitos, interesses e estratégias que permeiam seus diferentes sujeitos. As contradições espaços-temporais presentes no lugar são relegadas para segundo plano ou até mesmo negadas. Em alguns casos, o lugar surge como homogêneo, como portador da marca da cidade que perpassa a tudo e a todos. Negar o lugar em suas particularidades e contradições pode ser entendido também como estratégia política de reprodução do status quo. A adoção de um modelo educacional apostilado, que privilegia conteúdos gerais que de forma alguma são contextualizados e, por isso, apresentam-se como realidades em si mesmas, são algumas das práticas pedagógicas adotadas na EME Profa . Alcina Dantas Feijão. A compreensão da adoção de tal modelo passa, portanto, pelo entendimento da relação do mesmo com as questões políticas que permeiam a cidade e a escola em seus diferentes sujeitos.

Vale ressaltar que a adoção de sistemas apostilados de ensino tem sido uma marca constante das políticas públicas na área de educação implementadas em diversas cidades do Brasil. Um olhar mais atento acerca deste fenômeno poderia nos ajudar a compreender de que maneira a construção do conhecimento na escola tem ocorrido, bem como a participação dos diferentes sujeitos da 
educação neste processo. De forma geral, a adoção do sistema apostilado na EME Profa Alcina Dantas Feijão resultou, por parte dos docentes da unidade escolar, em um certo descrédito em relação a importância que possuem no interior do processo de ensino aprendizagem. Isso se revela, por exemplo, no momento de planejamento do ano letivo. Como pude perceber, para além do diálogo e da construção de um projeto de educação a ser desenvolvido, domina um certo conformismo em copiar, ano após ano, o índice da apostila, como se cumprir os conteúdos que ali estão postos fossem os únicos objetivos a serem alcançados no decorrer de um ano letivo. A ação crítica e criativa que pressupõe todo trabalho de planejamento e que é uma das bases e fundamentos para a construção do projeto político pedagógico é relegada a segundo plano, muitas vezes chegando a inexistir.

Da mesma forma, para muitos alunos, a repetição de métodos e de conteúdos, em um trabalho que lembra muitas vezes uma linha de produção em série, transforma a escola em um fardo a ser carregado. Para muitos, apesar de reconhecerem a chamada "qualidade do Alcina", veem pouco significado para além das questões burocráticas que permeiam a escola. Lembro-me de uma conversa que tive com uma das professoras de Sociologia da escola. No final do ano letivo de 2008, a professora me procurou para conversarmos sobre o rendimento de algumas salas de $3^{\circ}$ ano do Ensino Médio. Para a professora, era difícil compreender a tamanha apatia que acometia aqueles alunos a poucos meses de se formarem, de avançarem em seus estudos e em suas vidas profissionais. Propus-se, então, para a professora "bater um papo" com os alunos, tentar entender o que estava acontecendo e assim o fiz. Foi uma conversa extremamente reveladora. Nela pude perceber os significados de algumas práticas adotadas na escola e que refletiam claramente no imaginário e na forma como os alunos a concebiam. Segundo os alunos, por ser uma escola, como vimos, bastante tradicional e na qual a cobrança sobre os mesmo é muito elevada, eles tiveram que "aprender a jogar o jogo". Como toda a ênfase do processo de avaliação está posta nas semanas de provas, as energias dos alunos ficam nelas concentradas. É neste momento que criam estratégias tanto de estudo como de cola. Passada a semana de prova, tendo alcançado ou não o resultado necessário, é chegado o momento de repor as forças, momento da apatia em sala de aula, afinal de contas, ciclicamente, uma semana de provas os 
espera logo mais.

A sinceridade com a qual os alunos revelaram as estratégias para dialogar com as estruturas rígidas da escola me possibilitaram compreender de que maneira as relações sócio-espaciais que ocorrem no interior da escola podem ser mais complexas e repletas de múltiplos significados do que uma simples leitura possa imaginar. Uma ação estratégica dos alunos para enfrentar a dinâmica burocrática e autoritária implementada na escola se configurava para os professores como apatia ou mesmo como indisciplina. Neste momento, porém, o que mais me interessava era a clareza que os alunos possuiam acerca da falta de significado daquilo que realizavam em sala de aula. A partir desta discussão que tive com os alunos pude repensar algumas das minhas práticas em sala de aula, buscando dialogar mais claramente com questões relacionadas a lógica do lugar.

Outro elemento importante que pude compreender a partir de minha prática pedagógica em São Caetano do Sul diz respeito ao fato de que, nem sempre, uma disciplina teoricamente voltada para a produção de pesquisas científicas como o intuito de romper com as estruturas rígidas na qual estão pautadas muitas das etapas do processo de ensino-aprendizagem, assim se desenvolve. No currículo dos alunos do $3^{\circ}$ ano do Ensino Médio encontra-se a disciplina de monografia. Tal disciplina foi inserida no currículo dos alunos a partir da parceria que a escola desenvolve com a UNESCO, no Projeto de Escolas Associadas (PEA - UNESCO). Para manter a certificação da UNESCO, a escola precisa desenvolver projetos na área de pesquisa, dos quais a monografia é um deles. Nesta disciplina, os alunos recebem a orientação do professor de línguaportuguesa para que, durante um ano, possam elaborar a monografia a partir da pesquisa de um tema a ser escolhido pelo aluno. No final do ano, o aluno é submetido a uma banca de três professores, para quais apresenta e defende sua monografia. A banca de examinadores, por sua vez, questiona os alunos acerca de elementos do texto e da pesquisa e decidem pela aprovação ou não da monografia.

Pude participar de algumas bancas como examinador, fato este que me fez deparar com a seguinte situação: nenhuma das monografia, as quais tive o prazer de assistir, tratavam de problemáticas locais, relacionados a realidade social e 
política de São Caetano do Sul. Os temas, em grande maioria, se relacionavam as chamadas temáticas da moda: aquecimento global, guerras no mundo e faziam leituras superficiais sobre os mesmos. Além disso, percebi pela leitura das monografias e pela apresentação das mesmas que, em sua grande maioria, se tratavam de cópias de textos da internet. Havia, portanto, um certo distanciamento entre aquilo que se propunha enquanto processo de ensino, que seja, o desenvolvimento das metodologias relacionadas a pesquisa científica e aquilo que de fato se realizava.

Durante um dos horários semanais de encontro pedagógico (conhecidos como $\mathrm{HELP}^{8}$ ), indaguei o coordenador e outros professores sobre a forma como a monografia estava organizada. Nesta conversa, professores e coordenador me explicaram que, a partir da nova gestão municipal e da diretoria da escola, houve uma mudança brusca da organização da monografia. No início, ela havia sido pensada como uma prática de ensino relacionada a um processo de ensinoaprendizagem por meio de projetos. A monografia seria o ponto para onde convergiriam os projetos desenvolvidos pelos alunos, sendo que muitos destes projetos buscavam dialogar com problemáticas mais amplas a partir de questões locais. Ao invés de ser desenvolvida apenas no $3^{\circ}$ ano, o aluno, desde o $1^{\circ}$, já recebia orientações de um professor nos procedimentos e metodologias necessárias ao desenvolvimento do projeto. Além disso, a monografia era temática, sendo que os temas eram escolhidos por alunos e professores, privilegiando-se aqueles de maior relevância social e local.

Para os professores que puderam participar deste processo, a monografia estava inserida em outro projeto de escola, voltada para o diálogo e para a pesquisa e que tinham nos alunos e professores seus principais sujeitos. Pude perceber que os professores falavam com tristeza das mudanças ocorridas. Nesta tristeza, revelavam um pouco da impotência que sentiam frente aquela realidade. O poder centralizado e centralizador da atual gestão concebia o professor como mero cumpridor de ordens e de programas, decididos em reuniões fechadas, definidos pelos conteúdos pré-determinados dos materiais apostilados e que faziam parte de estratégias políticas que ultrapassavam os muros da escola. Pouco ou nada restava de poder e autonomia aos professores que acabavam,

Nome pelo qual é chamado o horário de trabalho pedagógico coletivo na EME Prof ${ }^{a}$ Alcina Dantas Feijão. 
assim, apenas executando as ordens que vinham da direção da escola. Esta sensação de impotência, por sua vez, resultava em um afastamento cada vez maior dos professores da escola como lugar de formação e produção de conhecimento, bem como de uma leitura mais crítica e criativa das problemáticas locais que interferiam diretamente em seu trabalho. $O$ cansaço decorrente das tantas mudanças de administração que resultavam, por sua vez, em mudanças no projeto da escola, trazia aos professores a sensação de que, naquele contexto, o mais correto a se fazer era se adaptar a tudo o que ocorria ao bel prazer dos ventos políticos da cidade. Para muitos, a escola, naquele modelo de gestão, significava mais lugar de repressão, de ordenação, do que possibilidade de partilha e de formação profissional.

Em outro HELP, esta sensação de impotência da maioria dos professores ficou mais clara. Indagado sobre o que estava achando sobre a escola, disse-lhes que me sentia um pouco confuso e que tal confusão decorria da seguinte situação: ao mesmo tempo em que estava na escola dos sonhos de qualquer professor, dotada de uma excelente infra-estrutura, com professores altamente qualificados, alunos interessados, sentia-me aprisionado a um modelo educacional pouco significativo para aprendizagem do aluno e para as minhas práticas profissionais e repleto de interesses e estratégias políticas. Disse-lhes, também, que não sabia se iria continuar no outro ano e que tal decisão dependia da resposta a pergunta que a seguir faria: qual a força política que tínhamos, como grupo de profissionais, para mudar aquela realidade? À pergunta seguiu um demorado silêncio. Depois de alguns minutos, alguns professores sorriam, outros desviavam os olhos. Foi então que obtive a resposta pela voz de um colega: "o problema é esse, nenhuma". Ali pude compreender o dilema na qual estavam inseridos tais professores e no qual, naquele momento, acabava de me inserir. Tratava-se, portanto, de um embate político que perpassava as relações entre os diferentes sujeitos da educação e o lugar no qual estão inseridos e que com suas práticas sócio-espaciais ajudam a configurar. Por mais que a escola negasse em discutir as questões relacionadas ao lugar, eram elas, em grande medidas, que interferiam diretamente naquilo que ocorria no interior da escola. Era preciso, portanto, repensar a relação entre escola e lugar no interior do Alcina.

A experiência advinda das discussões ocorridas durantes os encontros do HELP me permitiu compreender uma outra perspectiva da escola a qual, até 
aquele momento, ainda não tinha tido acesso. Tratava-se daquilo que não é dito na escola, do que está oculto nas entrelinhas da cultura escola, mas que também determina, de certa maneira, as relações sócio-espaciais que ali ocorrem. Com o Help pude perceber que existem muito mais coisas que não são ditas na escola e que muitas vezes aparecem despercebidas nas análises que se produzem acerca das relações sócio-espaciais que a configuram. De certa maneira, o não dito revela as estruturas que permeiam as relações de poder na escola, permitindo ao pesquisador compreender determinadas funções e lugares sociais que cada um dos sujeitos que fazem parte destas relações ocupam nesta determinada estrutura. Não se trata, porém, de uma estrutura pré-determinada. Ao contrário, são as relações em sua dinâmica que configuram e reconfiguram as estruturas de poder. Os lugares e as funções sociais não são fixos. Um mesmo sujeito pode ocupar diferentes lugares e funções sociais numa mesma estrutura dependendo da inter-relação que desenvolve com outros sujeitos, em suas funções e lugares sociais.

Neste sentido, para além de uma estrutura estanque é preciso pensar a escola como lugar em processo, em produção constante, sendo que tais processos estão diretamente relacionados com os interesses e estratégias dos diferentes sujeitos que configuram a escola e o lugar da qual a mesma é causa, consequência e relação.

Como vimos, inseridos naquele contexto, os professores deparavam-se com uma série de dilemas éticos e morais que perpassavam sua prática docente. Com o tempo, pude perceber que aquele silêncio inicial, que havia presenciado na sala dos professores e que tinha tomado minha atenção, não significava passividade ou sinal de submissão; era antes questão de sobrevivência profissional, estratégia política fundamental para que os professores, imersos naquela determinada estrutura de poder, pudessem se reproduzir. Tudo na escola girava em torno da aceitação maior ou menor que os professores tinham daquele modelo de educação ali implantado.

Um dos exemplos que pude presenciar e que revela as estratégias de controle e de submissão na qual estavam inseridos os professores diz respeito ao processo de atribuição de aulas. A atribuição de aulas era feita a critério da 
diretora da unidade escolar. Os critérios que definiam a classificação dos professores eram decididos diretamente pela diretora da escola e avisados aos professores no final do ano letivo. E nem sempre os critérios eram muito justos. Em certa medida, pautavam-se em atributos subjetivos. Dependia da relação que o professor possuía com aquele modelo educacional ali implantado e com a figura que o representava, ou seja, a diretora da escola. O bom professor era, portanto, aquele que se submetia totalmente aquele modelo, mesmo que para isso tivesse que abrir mão do próprio significado da educação. Para este professor submisso, considerado eficiente, o maior número de aulas era oferecido. Para os outros que não se encaixavam neste perfil as últimas opções. Havia, portanto, um critério personalista no processo de atribuição de aulas que acentuava o caráter autoritário do modelo de gestão educacional implementado na EME Profa . Alcina Dantas Feijão entre 2005 e 2008.

Era clara uma certa diferenciação entre os professores no que diz respeito a aceitação ou não das regras impostas pela direção da escola. Havia professores que, assim como os alunos, haviam aprendido a "jogar o jogo". Faziam de tudo para não serem notados. Pouco expressavam suas opiniões e pensamentos sobre a questões pedagógicas e políticas que ali se configuravam. Suas críticas, feitas em voz baixa e com o menor número possível de pessoas, era mais direcionadas a determinados personagens do que ao modelo de gestão ali implementado. Na visão da direção da unidade escolar, eram considerados professores bons porque, simplesmente "não davam trabalho", ou seja, não criavam questionamentos para aquilo que, na visão da direção, deveria ser cumprido sem que maiores entraves fossem levantados.

Por outro lado, existiam os professores que, em momento algum, se furtavam de emitir opiniões e de deixar bem claro suas posições políticas e pedagógicas. Corriam o risco de, em um modelo de gestão autoritário, propor o diálogo e a democracia nas tomadas de decisões acerca da organização e dos projetos que envolvem a escola. Lembro-me de um professora de história ${ }^{9}$, há mais de 23 anos lecionando no Alcina, que em nenhum momento deixava de se posicionar. Era odiada pela diretora da escola que entendia que as opiniões emitidas pela professora eram ataques pessoais e não direcionados ao modelo de

9 No final de 2008, em decorrência também da falta de sentido do fazer pedagógico no interior de uma gestão escolar autoritária, tal professora inscreveu-se no programa de demissão voluntária da Prefeitura de São Caetano do Sul. 
educação ali implementado. Muitas vezes, tal professora era voz única em defesa dos direitos de alguns alunos. Em um episódio, defendeu a não-reprovação de um aluno do $3^{\circ}$ ano do ensino médio noturno por considerar se tratar de um aluno trabalhador e que muitas vezes chegava exausto ou mesmo acabava não indo as aulas. Com a negativa da diretora da escola em aceitar a aprovação, muitos professores que antes apoiavam o pedido da professora, voltaram atrás em sua decisão, o que resultou na aceitação do processo de reprovação do aluno. Uma semana depois, a diretora, pressionada pela diretoria regional de educação, viuse obrigado a rever sua posição e reconvocou o conselho para decidir a aprovação do aluno. Com o voto favorável da diretora, o aluno foi aprovado por unanimidade.

Além destas relações entre os diferentes sujeitos da educação nos conselhos de classes, as relações presentes no lugar vieram a tona muitas vezes. Uma das situações que mais me chamou atenção tratou-se da análise de desempenho de um aluno que era descendente de pais nordestinos. Após a análise e de uma série de discussões acerca do rendimento do aluno, a diretora da escola afirmou, de forma irônica, que o seu baixo rendimento estava relacionada ao fato "de ele vir lá de cima", referência clara ao fato do aluno ser descendente de nordestino. Representante de uma das famílias mais tradicionais de São Caetano do Sul, a diretora não se furtava em emitir opiniões preconceituosas acerca das origens e das condições sócio-econômicas dos alunos. Tais opiniões, porém, não se tratavam apenas de expressões particulares, mas revelavam o próprio preconceito presente no discurso histórico-geográfico presente em São Caetano do Sul. O que mais me chamou atenção é que, apesar de presenciarem um claro ato de preconceito, não houve nenhum tipo de manifestação por parte dos professores e o conselho continuou sem nenhum alarde. A maioria dos professores presentes no conselho, como pude constatar em conversas posteriores, não concordava com o que havia sido dito. Ir contra aquele pensamento, naquele momento, porém, significava, para muitos dos professores, mudar de lugar e de função na estrutura de poder da escola.

Os conselhos de classe, portanto, se tornavam momentos de cumprimento burocrático de um processo relacionado a estrutura de poder da escola. Nele, suas regras e procedimentos estavam claros. Quanto mais tempo um professor 
permanecesse em silêncio, maiores seriam suas oportunidades de se manter no mesmo lugar e na mesma função dentro da estrutura de poder da escola. Em certo sentido, era um estímulo para que o professor não manifestasse sua opinião e continuasse a não participar das decisões e dos rumos da escola.

Como, então, pensar a educação a partir deste modelo de gestão pautado no silencio e na aceitação de normas, regras e opiniões que muitas vezes ferem a própria ética docente? Pode um professor burocratizado pela ordem do poder tornar-se sujeito de suas próprias práticas? Qual o preço, profissional inclusive, que deve se pagar ao trazer o lugar, em todas as suas contradições para o interior da escola, inserindo-o como elemento a ser analisado, compreendido e criticado?

Para que pudesse compreender de maneira mais detalhada as relações existentes entre os professores, o lugar e as questões relacionadas a estrutura de poder na EME Prof ${ }^{a}$ Alcina Dantas Feijão, apliquei um questionário ${ }^{10}$ aos professores do Ensino Médio da escola. Foram entrevistados quatorze professores de Ensino Médio que lecionam no período matutino e noturno. Para que pudéssemos obter respostas mais amplas, escolhemos professores com tempos de ingresso na carreira docente diferenciados. Vale ressaltar, que no ano de 2007 houve uma grande renovação do quadro de professores da EME Prof ${ }^{a}$ Alcina Dantas Feijão em decorrência do plano de demissão voluntária instituído pela Prefeitura Municipal de São Caetano do Sul e que visava substituir funcionários já aposentados por novos. Este elemento de diversificação do quadro de docentes que compõem a citada instituição foi fundamental para que pudéssemos obter diferentes visões, resultantes de trajetórias de vida e de carreira diferenciadas, acerca de questões relacionadas as práticas pedagógicas e as percepções das relações existentes entre escola, saber e poder.

No primeiro gráfico, podemos observar que a maioria dos professores que atuam no Alcina possui mais de 5 anos de atuação na carreira docente, sendo que na escola atuam professores com mais de 25 anos de inserção profissional no magistério. É importante ressaltar que esta inserção mais longa na carreira docente é fundamental para que possamos compreender de que maneira os professores entendem as transformações ocorridas nas últimas décadas relacionadas às práticas da profissão, visto que muito dos professores entrevistados tiveram suas carreiras marcadas por diversas transformações

\footnotetext{
10 O questionário encontra-se nos anexos deste relatório.
} 
políticas e pedagógicas da educação em seus diferentes sistemas (municipal, estadual e federal). São professores também que têm uma formação diretamente relacionada a sua história de vida e que aprenderam a valorizá-lo como elemento de formação continuada, mesmo que tal elemento, no âmbito político seja visto como pouco importante neste processo, como veremos mais adiante.

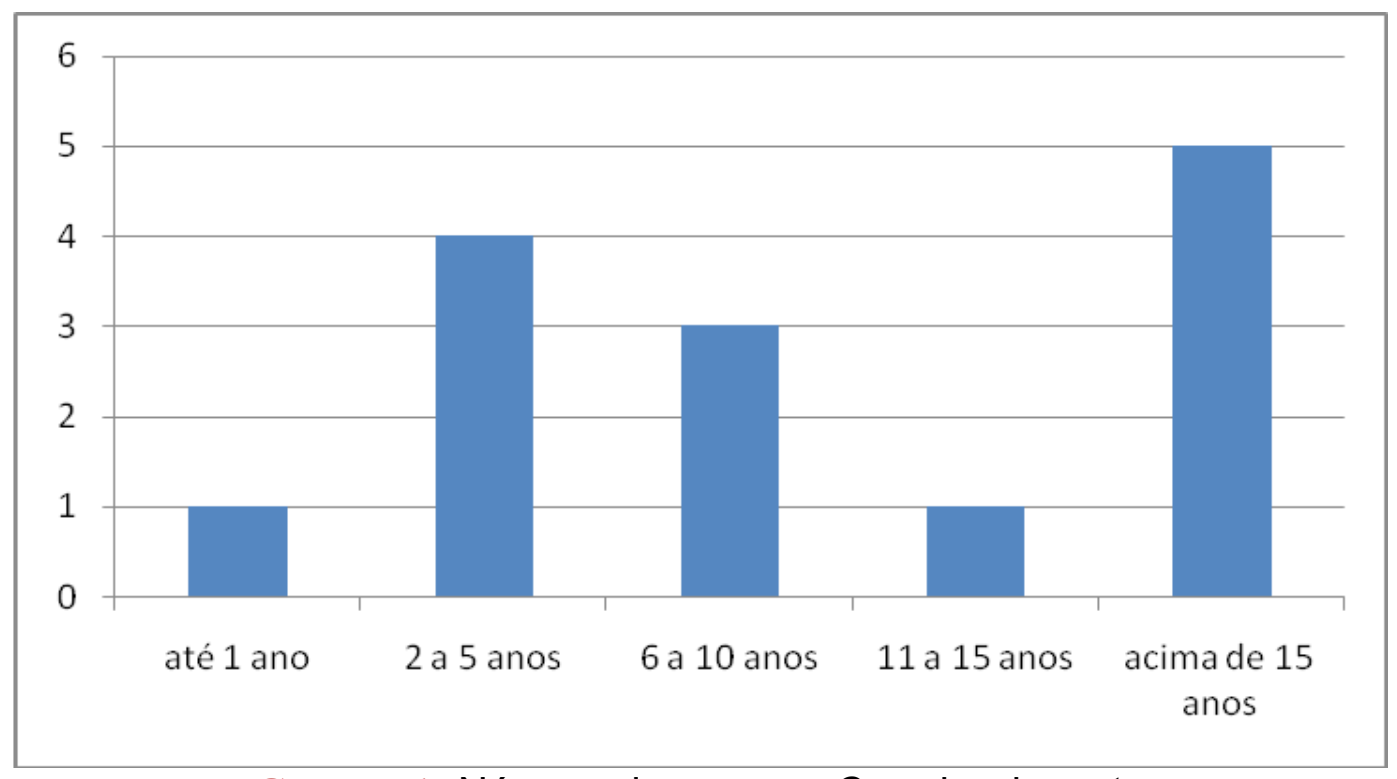

Gráfico 1: Número de anos na Carreira docente

Em relação ao tempo de atuação na EME Profa Alcina Dantas Feijão, podemos verificar pelos dados apresentados no gráfico 2, que existe um número elevado de professores que estão há menos de 1 ano na escola. Tal fato se explica, como já dissemos, pelo processo de reestruturação dos funcionários públicos ocorridos no ano de 2007. Estes novos professores inserem-se em um quadro composto por professores bastante experientes, que já estão na escola há mais de 15 anos, o que possibilita, em certam medida, analisar as diferentes percepções que existem entre professores com tempo e trajetória de carreiras diferentes. Entre os professores novos - e aqui tenho a possibilidade de falar a partir de minha própria experiência - existe uma percepção de que as relações que existem na escola são diretamente relacionadas as questões de ordem política, principalmente na esfera municipal. Essa influência política aparece em várias das respostas às perguntas abertas feitas no questionário. Diferente dos professores mais antigos, que se sentem receosos de que as respostas dadas possam lhe comprometer, os professores mais novos, ainda pouco habituados a configuração e as múltiplas implicações das relações de poder na escola, sentemse mais a vontade para escrever e dizer o que pensam e sentem sobre a 
situação.

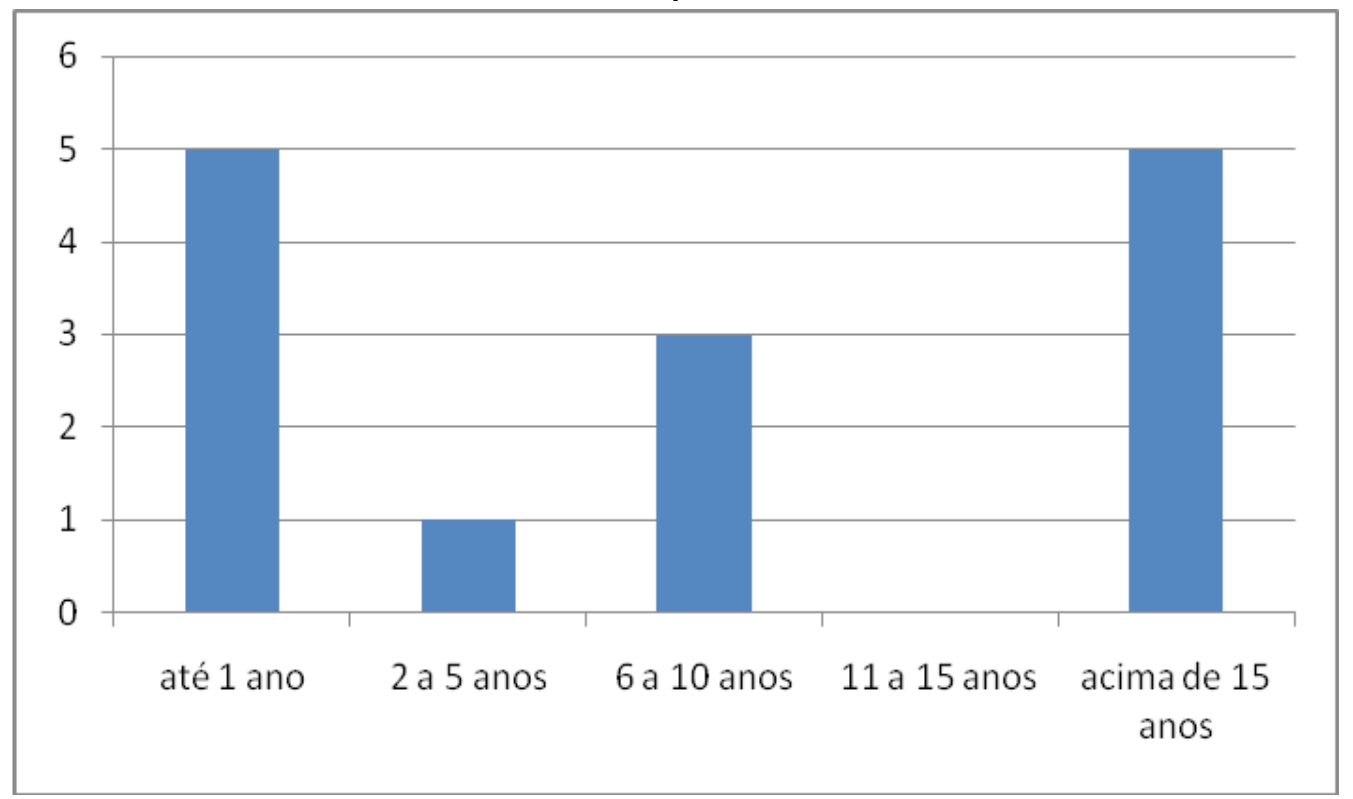

Gráfico 2: Número de anos como docente na EME Profa Alcina Dantas Feijão

Outro elemento importante, apresentado no Gráfico 3, diz respeito a formação inicial dos professores. Como podemos ver, a grande maioria dos professores fizeram sua formação inicial em universidades particulares. Dos quatro professores entrevistados que fizeram sua formação inicial em universidades públicas, três deles estão há menos de 5 anos na escola, sendo que 2 ingressaram no quadro de professores em 2007, o que em certa medida indica, pelo menos em tendência, no caso do Alcina, uma maior inserção de docentes vindos de Universidades Públicas nas Escolas de Educação Básica Públicas. 


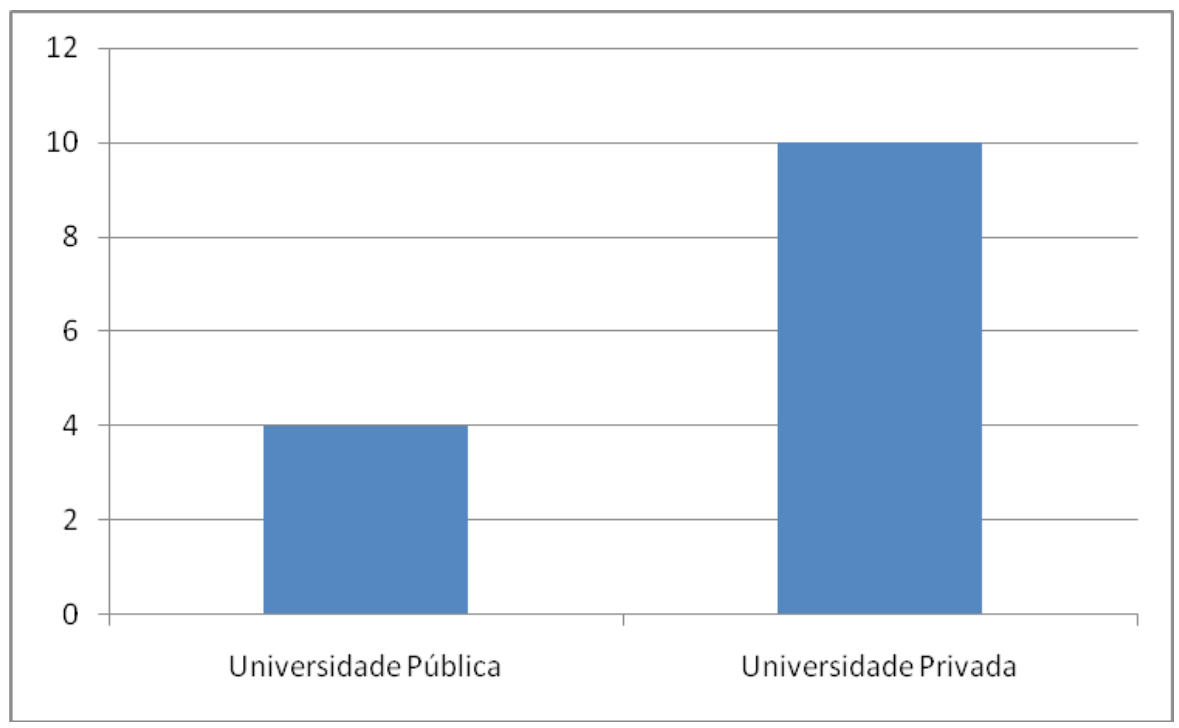

Gráfico 3: Tipo de Instituição de formação Inicial

No Gráfico 4, podemos analisar as percepções que os professores possuem acerca da relação entre a escola e o processo de formação continuada. Em nossa perspectiva, analisar a formação continuada como processo que ocorre também no interior da própria escola nos permite compreender um pouco melhor as relações que os professores possuem com a escola e os significados que à ela os mesmos atribuem. Uma escola da qual os professores pouco participam dos múltiplos processos que a envolvem, que vão desde as experiências da sala de aula até a participação em fóruns de decisão como os conselhos de escola, Apm, entre outros, revela um certo modelo de gestão educacional que tem na reprodução da burocracia e no autoritarismo seus principais alicerces. As respostas obtidas e apresentadas no gráfico abaixo revelam um pouco mais acerca da relação que os professores do Alcina possuem com a formação continuada pensada e realizada a partir da escola. 


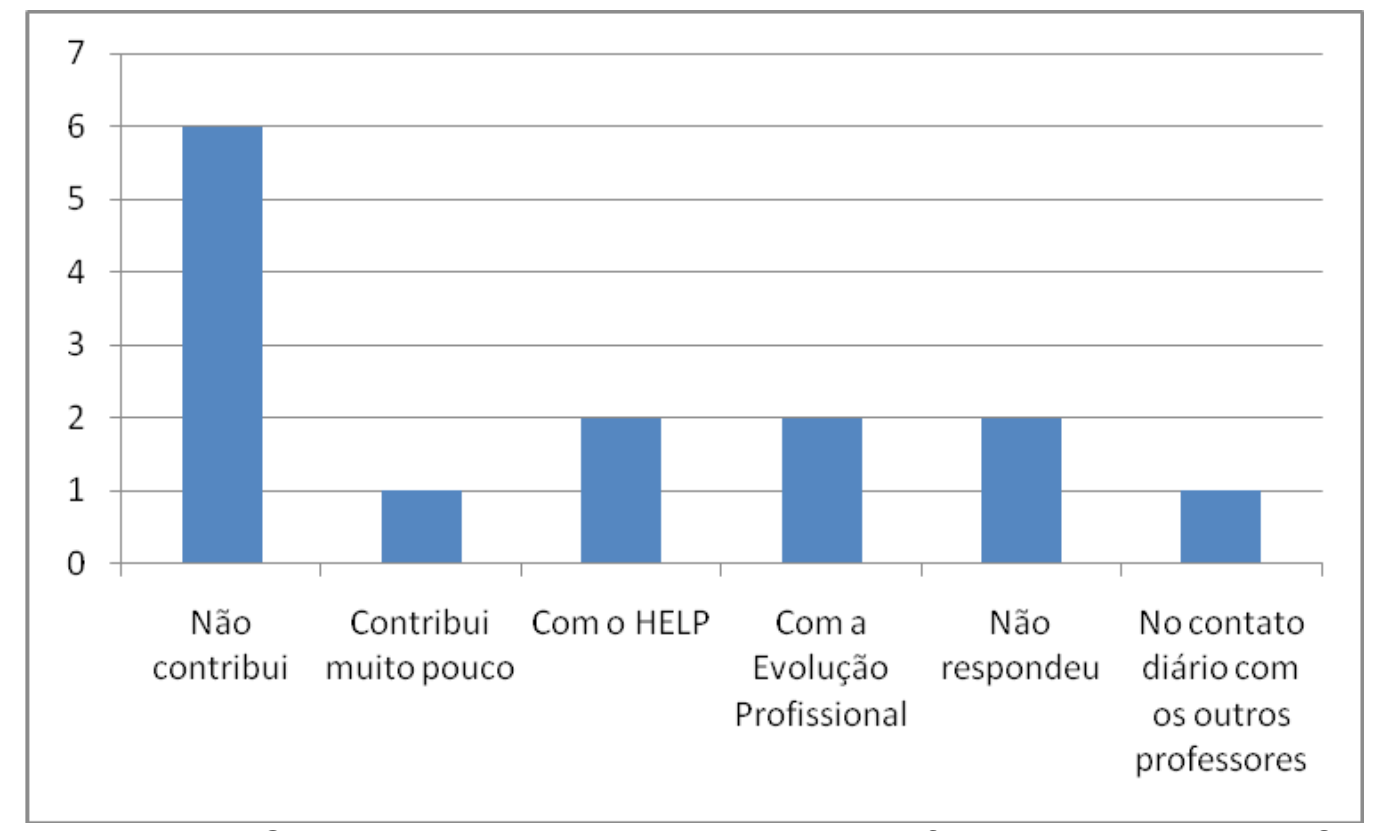

Gráfico 4: Como a escola contribui para a sua formação continuada?

Como podemos perceber, a maioria dos professores afirma que a escola nada ou muito pouco contribui neste processo. Mesmo o momento dedicado a este processo, o HELP, recebeu apenas 2 citações, o que representa um certo descrédito, por parte do corpo docente, das atividades que ali ocorrem. Em conversas informais realizadas com alguns dos professores, a grande questão que envolve o descrédito em relação ao HELP diz respeito ao fato de que há uma lacuna entre aquilo que se discute e se propõe e o que de fato é permitido realizar. Muitos dos projetos que elaboramos no âmbito do HELP não foram postos em prática por intervenção da direção da escola. Tal situação resulta em um aumento do desânimo e do descrédito daquele momento frente às decisões e as práticas realizadas na escola. Esta dualidade entre a riqueza das discussões e dos projetos elaborados no HELP e as decisões centralizadas da direção da escola ocasionava uma certa tensão, uma situação de conflito que na maioria das vezes pendia para o lado da direção da escola e do modelo de gestão por ela implementado.

Em entrevista realizada com o Coordenador do Ensino Médio, Paulo Sérgio Garcia, obtivemos algumas informações sobre o processo de implantação da formação continuada na EME Profa Alcina Dantas Feijão. No trecho que apresentamos a seguir, o entrevistado explicita o processo de implantação da formação continuada, bem como os empecilhos que o mesmo sofreu. 
Vou tentar fazer uma trajetória: quando nós começamos aqui como coordenador em 1993, não tinha formação de professores. A escola sempre foi muito bem conceituada, porque ela cumpre uma função política também, mas eu não queria entrar... na cidade ela é uma... ela cumpre uma função política, tem muito vereador que pede vaga, aquelas questões todas, mas não tinha formação de professores. Em 1997 quando o Pacífico assumiu, pela primeira vez já tinha formação de professores em todo lugar, todas as escolas faziam formação de professores, então nós pensamos em um projeto que tinha dois canais bastante claros. Um deles era a entrada de coordenações de áreas na escola, que também não tinha: a Maiberte pegou ciências e tecnologias que é área do ensino médio, a Denise pegou ciências da natureza, tinha a área de história etc., e matemática não me lembro. Então, tinha um propósito, começar com as coordenações de áreas, por que era muito grande, tudo muito grande, tinha de 150 a 200 professores, médio e fundamental, duas unidades. E pensamos por outro lado a formação de professores, eu escrevi esse projeto, até estava junto quando o Pacífico levou ao prefeito, inclusive já falecido, e era uma estrutura grande, ela visava o seguinte, o professor teria 8 aulas, 2 tardes de formação na estrutura geral e teria uma outra parte de formação que nós conseguimos que estava ligada a essa área, porque por exemplo, não existia computador na sala dos professores, não existia disponibilidade de laboratório, tudo isso nós fomos criando naquela época. $\mathrm{Na}$ sala dos professores a previsão inicial era de 8 computadores para os professores trabalharem, ninguém nessa ala tinha computador e eu trazia Lap Top e as pessoas achavam que eu era fresco: "você é maluco!", isso em 1997, mas a escola já tinha tido um projeto que eu trouxe para cá para São Caetano, chamado "Escola do Futuro", não sei se você conhece, falava da ECA não sei se ainda continua, em 1993 teve em São Caetano. E ai nós começamos, mas na hora de debater eu mostrei para o professor Edson e ele disse "vocês têm duas aulas" e foi o que ficou de lá para cá, o Pacífico não tinha uma força política para mexer com isso, a Arlete que veio depois também não, enfim conseguimos duas aulas, porque antes disso também não tinha nada, nada, não existia formação de professores, não que se de para fazer alguma coisa com 2 aulas.

No trecho acima, podemos perceber alguns elementos fundamentais para a compreensão do modelo de formação continuada que tem sido posto em prática na EME Profa Alcina Dantas Feijão. De um projeto que propunha um número importante de aulas (8) para a formação dos professores na própria escola, restou 
a aceitação de 2 aulas semanais, utilizadas em grande maioria para dar recados da direção e realizar atividades como correções de prova, preenchimento de diários. Ao invés de se realizar enquanto momento de ação coletiva dos professores, de troca de experiências de aulas, de partilha e de elaboração de novos conhecimentos calcados nas experiências trazidas por cada um dos professores, o horário denominado de Help se configura, portanto, quase como um pedido de socorro dos professores que vêem quadruplicar as atividades pelas quais passam a ser responsáveis sem que haja um aumento do tempo para a formação e a elaboração das mesmas. Há, portanto, uma restrição de tempo e de espaço para que a formação continuada ocorra na própria escola, para que, de fato, os professores se apropriem das condições e dos processos que influencia diretamente em suas práticas docentes e pelos quais, em certa medida, também são responsáveis. Neste sentido, há uma certa restrição de se pensar a formação do professor a partir do lugar e das problemáticas que o mesmo traz, das condições reais nas quais alunos, professores e toda a comunidade escolar estão inseridos.

É interessante notar como a não aceitação do projeto inicial de formação continuada é atribuída a força política que as diferentes direções da escola tinham para encampar ou não o projeto. Como dissemos, nossa pesquisa busca não compreender a escola por si mesma, mas como um espaço social, inserida em um determinado lugar, e que é resultado das relações dos diferentes sujeitos e de suas intenções. Neste sentido, é fundamental que analisemos de que maneiras as relações de poder implicadas no lugar contribuem na definição e redefinição das relações sócio-espaciais que configuram a escola como espaço-social.

Como vimos, o poder e as relações estabelecidas através dele é um dos elementos mais importantes que definem a relações na EME Profa . Alcina Dantas Feijão. Como afirma Paulo, a escola cumpre uma importante função política na cidade e é exatamente por cumprir tal função que sofre com interferências externas que se pautam mais em interesses políticos do que pedagógicos. A presença de políticos (prefeitos, vereadores) é bastante comum e, na maioria das vezes, interfere nas práticas cotidianas de professores e alunos. Em certa medida, a escola cumpre função fundamental no processo de reprodução no poder de certas elites locais que vêem na escola lócus propício para a autopromoção e campanha político-partidária. Para além de lugar da realização 
efetiva de direitos a escola, enquanto espaço do poder local, reproduz os privilégios de uma certa elite política que a vê e pensa como lugar de poucos e para poucos.

Esta presença do poder local foi citada também pelos professores no questionário aplicado. No gráfico 5 , indagados sobre a influência da cidade sobre suas atuações como docentes na EME Profa Alcina Dantas Feijão, a maioria dos professores aponta a existência de interferências políticas e pedagógicas.

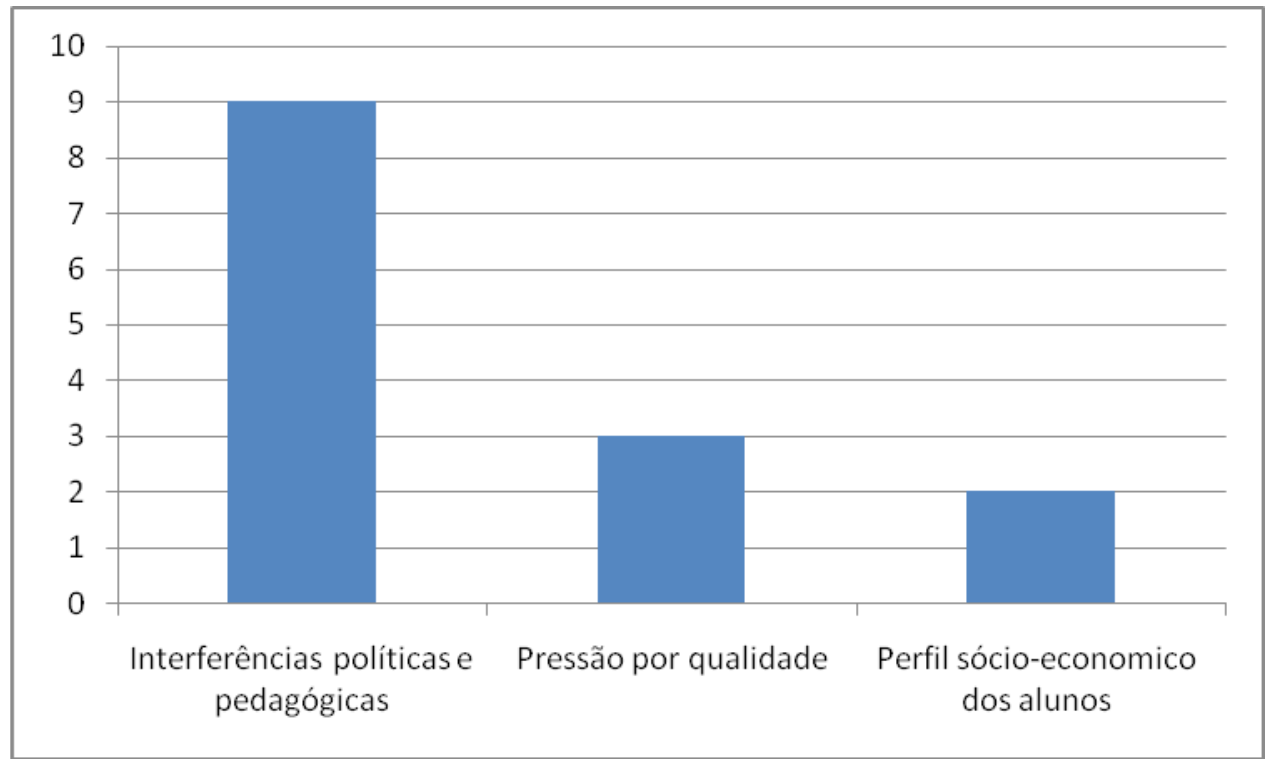

GrÁFICo 6: Como a realidade da cidade influencia em sua atuação na EME Profa Alcina Dantas Feijão?

Em um das respostas dadas por um professor que respondeu ao questionário aplicado, encontramos uma clara descrição da percepção das relações de poder existentes na escola, resultado da relação com o lugar na qual está inserida, neste caso, a cidade de São Caetano do Sul. Vale ressaltar que se trata de um professor que está há menos de 1 ano na escola e que, em certa medida, sente-se mais a vontade para falar de suas percepções.

A política municipal é prioritária. A necessidade política substitui, muitas vezes, a necessidade educacional. Tudo é alterável em prol de interesses políticos momentâneos

Esta mesma percepção pode ser encontrada no trecho a seguir, transcrito da entrevista com o coordenador do ensino médio.

Então essa relação de política esta presente em todas as 
escolas de uma forma ou de outra, mas aqui ela é bastante... e ela determina, por que, mudou o prefeito muito bem, muda a secretária de educação, muda o diretor da escola, o diretor, o que ele faz, muitos deles chegam e olham quem é a parte técnica, alguns aproveitam, outros trazem o pessoal deles, e ele vem com a linha dele, ele quer apostila...

A pressão externa sobre a escola pode ser percebida, como apontam os dois fragmentos acima, na alternância da direção de escola. Como não existe concurso público para os cargos técnicos da escola (diretor, vice-diretor coordenação) existe uma grande rotatividade dos mesmos, o que resulta em mudanças constantes de linha pedagógica e política. Como afirma Paulo, cada diretor, ao assumir o cargo, define a linha pedagógica da escola que, na grande maioria das vezes, está pautada nos interesses políticos que a escola cumprirá na estrutura do poder municipal. Se o interesse for por números, a escola adotará apostilas, fará parcerias com sistemas de ensino privados, buscando aumentar o número de aprovação para o vestibular. Ao contrário, se a idéia for um modelo de educação mais democrático, far-se-á aumentar o acesso e as possibilidades de permanência na escola. Se ambos forem os objetivos, não se medirão esforços para alcançá-los. No meio deste jogo político, que envolve a relação da escola com o lugar e com o poder, estão professores e alunos, reféns, em certa medida, das mudanças de rumo pedagógico. A sensação presente na maioria da resposta dos professores entrevistados, é a de que apenas cumprem ordens que pouco entendem, questionam e que em nenhuma medida, ajudaram a construir.

Como ser então professor em uma escola da qual não participam, na qual os interesses privados estão acima da esfera pública? Em uma das perguntas realizadas, os professores tiveram que apresentar suas opiniões sobre o que seria um professor-pesquisador. A seguir, elencamos algumas das definições apresentadas pelos professores entrevistados:

\section{Como você definiria um professor-pesquisador?}

"Que está envolvido com pesquisas relacionadas a práticas pedagógicas"

"Professor que busca novos conhecimentos"

"Professor preocupado com sua atualização profissional” 
"Professor que investiga a realidade"

"Professor que concebe as dificuldades como objeto de reflexão"

"Aquele que busca compreender as situações vividas na Educação"

"O ser que procura sempre uma resposta para a verdade do universo"

"Que evolui com o mundo, que não se acomoda e está sempre em busca do "aperfeiçoar"”'

"Existem muitas possibilidades no campo da pesquisa, mas os colegas (ai me incluo) não sabem bem como se aproveitar disso".

“Um professor não acomodado"

"Um professor que trabalha constantemente buscando uma atualização de conhecimentos e métodos de trabalho"

"Professor pesquisador é aquele que não somente transmite, mas também forma conhecimento por meio de pesquisas, análises, comparações e reflexões"

“O professor pesquisador é um “autodidata', ele procura o conhecimento necessário para o seu desenvolvimento pedagógico e tenta aplicá-lo em seu dia-a-dia"

"Sempre insatisfeito com o seu saber, com o modo de abordar os temas; desejoso de sempre oferecer novos conhecimentos e sentidos. A pesquisa, dissociada da docência, no mais amplo sentido da palavra, é elogio a si mesmo"

A idéia de professor-pesquisador, apresentada pela maioria dos professores entrevistados, está baseada em uma idéia bastante vulgarizada do que vem a ser a pesquisa, principalmente no que diz respeito à pesquisa científica. A análise das respostas dos professores permite-nos, pelos menos em uma primeira perspectiva, apontar a existência de uma real separação entre os professores da educação básica e a produção do conhecimento em termos de produção científica e acadêmica.

Outro aspecto importante diz respeito ao fato de que a maioria dos professores aponta o professor pesquisador como um indivíduo isolado, que produz pesquisa a partir de suas práticas e não na relação com os seus pares, com os outros sujeitos da educação que não são apontados aqui como sujeitos de produção de conhecimento por intermédio da pesquisa. Termos como "solitário" e "autodidata" foram citados para caracterizar o professor pesquisador e 
revelam esta concepção analisada anteriormente.

Esta mesma concepção pode ser encontrada nas respostas obtidas em outra das questões formuladas para o questionário. Abaixo elencamos algumas respostas.

\section{Como a pesquisa poderia contribuir em sua formação continuada?}

"Aumentando conhecimentos e minha qualidade profissional"

"A pesquisa é fundamental"

"Fundamental para entender atitudes, decisões e tomadas de decisões"

"Faz com que eu me torne um profissional mais preparado"

"Não creio na pesquisa acadêmica como poder de transformação social"

"Ajuda a compreender melhor o contexto que ele e a sociedade que ele pertence estão inseridos"

"Amplia sua visão e melhora a sua compreensão nas dificuldades pedagógicas"

"Amplia e atualiza o conhecimento referente a nossa área de formação ou prática pedagógica”

"Qualquer profissional precisa se especializar e procurar alternativas de estudo, somente aquele comprometido com a educação é capaz de fazer "na sala de aula" o seu papel, mostrando ao aluno que o indivíduo pode começar a fazer a diferença"

"Ela colabora na medida em que a investigação sobre os temas de interesse ou aqueles que se constituíram em problema na docência, permitirá o aprofundamento do conhecimento e da complexidade do tema, bem como, poderá apontar outros caminhos para a prática de ensino"

"Por meio da pesquisa, podemos descobrir novas informações, ter uma visão mais ampla a respeito de determinados assuntos, fazer relações entre temas/definições a fim de melhorar o "fio de raciocínio", além de descobrir/criar novas práticas didáticas"

De maneira geral, a pesquisa aparece relacionada a transformação profissional do professor pensado como indivíduo isolado do grupo, que pensa sua formação por si mesmo, independente dos caminhos que o grupo do qual faz parte, resolveu trilhar. Se levarmos em consideração as respostas obtidas com as duas questões anteriores, podemos pensar que a pesquisa talvez seja a atividade 
mais solitária que compõe as atividades docentes. Não houve, em nenhum momento, alusão ao papel da pesquisa como mediação das relações entre os docentes e da construção de possibilidades de discussões e produção de conhecimentos e caminhos comuns que levem a um melhor desenvolvimento do processo de ensino-aprendizagem para todos os sujeitos da educação. Ao contrário, a pesquisa é vista e entendida como atividade voltada para si mesma que tem como principal objetivo transformar o professor em um profissional melhor.

que acima analisamos nos leva a uma questão fundamental acerca do papel da pesquisa e da produção do conhecimento que tem na escola lugar essencial de sua realização, que seja, quais elementos contribuem para essa produção do isolamento na escola (isolamento social, profissional, acadêmico)? Existe um modelo de formação continuada que tem sido posto em prática em muitos sistemas de ensino no Brasil e que vemos se reproduzir no município de São Caetano do Sul, em específico na EME Profa Alcina Dantas Feijão, que pensa a formação dos professores fora do ambiente escolar, muitas vezes até desvinculada deste e que tem relação direta com o conceito de Extensão Universitária que será discutido no próximo capitulo. Valorizam-se cursos e mais cursos realizados em instituições de ensino externas, muitas delas com pouco e nenhuma credibilidade, enquanto é deixado de lado àquilo que professores e alunos produzem e constroem em suas práticas cotidianas. Estas produções cotidianas são entendidas como pouco importante na formação do profissional docente e, portanto, não valorizadas na evolução profissional do mesmo. A valorização de conhecimentos externos é elemento fundamental na reprodução da hierarquização do saber que coloca a universidade como centro privilegiados da produção do conhecimento. Cabe, portanto, a escola básica ser alvo das diferentes ações e metodologias propostas por pesquisadores, totalmente desvinculadas da realidade sócio-espacial na qual estão inseridas.

Essa desvalorização das práticas e conhecimentos docentes adquiridos no trabalho diário dos mesmos pode ser exemplificada com a própria estruturação do tempo e do espaço do trabalho docente. Como foi apontado por Paulo, no trecho da entrevista que apresentamos, há uma ideologia de que não se pode dar tempo para que o professor permaneça na escola. É preciso condená-lo a tirania da sala da aula, do giz e da lousa. Em que momento, no ambiente escolar o professor 
reflete sobre sua prática, sobre o contexto e o lugar de onde atua? Em que momento esta reflexão se torna reflexão coletiva? Em que momento a reflexão coletiva gera outras práticas e ações, se transformando, portanto, em formação continuada, em processo? Há uma lógica imperante, que seja, a da hierarquização do acesso à produção do conhecimento e da transformação do saber em mercadoria, que a reproduz e que aliena os sujeitos que dela fazem parte, mesmo que na forma de sujeitos-objetos.

Paulo cita um exemplo na entrevista concedida que revela o fato de que o professor modifica suas práticas quando é chamado a participar das decisões da escola.

\begin{abstract}
Então o sistema de formação foi muito interessante, foram 3 anos e isso resultou em novos currículos, em todos os cursos os currículos foram refeitos. Os sujeitos vinham com... quando o professor pode decidir, quando ele tem poder, eu também pos... eu posso, não é. Então ele participa, eles vinham. Eu nunca escrevi sobre isso por que não era muito a minha área, mas foi a maior experiência que eu passei aqui...

Eu tive um professor o Afonso, não sei se você conheceu.

Esse era problema. Ás vezes ele sentava, pegava uma cadeira assim, e lá ficava. Ele gostava de reter aluno, e ele participou dessa experiência, e ele começou a desenvolver jogos, ele dava materiais, curso, parte técnica, ele começou a desenvolver um jogo em que o aluno ia jogando e aprendendo o processo de como você faz requisição de material, era um negócio enorme, você jogava com dados e em casa você tinha que relatar um negócio em relação aquilo, uma ferramenta muito interessante que ele desenvolveu. Então a partir de uma experiência de currículo os professores passaram a desenvolver ferramentas ou sei lá qualquer coisa para ser utilizada, porque se você... esse acho que é um dos motivos da formação de professores, porque se não os professores ficam muito ali no giz e na lousa, mas as vezes, nem é porque ele não quer, não é, ele não tem tempo para desenvolver.
\end{abstract}

Neste sentido, a relação do professor com a escola e com o lugar depende, em grande medida, da forma como o espaço-temporalmente a escola está organizada e da forma como, politicamente, ela é gerida. Apesar de garantida em lei, a Gestão Democrática da Escola, em suas diferentes implicações, como pudemos perceber, está muito distante de uma práxis efetiva. 
Ao mesmo tempo, ao se implantar um sistema de evolução funcional que se baseia apenas nos cursos e títulos obtidos pelos professores, entendidos aqui como profissionais individualizados e isolados, produz a lógica da segregação que reforça e é reforçada, como vimos, pela lógica da transformação do conhecimento em mercadoria. A formação continuada surge mais como elemento de evolução profissional - principalmente financeira - do que como elemento fundamental para uma prática pedagógica mais criativa e significativa. Torna-se, portanto, em uma disputa entre os professores para ver quem obtém mais pontos e assim pode escolher as melhores classes para lecionar. A escola, pensada como espaço social, público e coletivo ao mesmo tempo, na qual sujeitos se relacionam baseados em suas intencionalidades e não-intencionalidades, fica em segundo plano nas preocupações dos diferentes sujeitos da educação, que nesta lógica cotidiana, estão, em certa medida, isolados. Enquanto isso, múltiplos interesses invadem a esfera escolar e sem encontrar grande resistência, já que a lógica do isolamento dos sujeitos é reinante, altera-a em prol de benefícios próprios.

É isso o que constatamos na EME Prof ${ }^{a}$ Alcina Dantas Feijão. Há pouca ou nenhuma resistência as mudanças resultantes de intervenções políticas que ocorrem na escola. E não há, porque em certa medida, os professores não se sentem parte de um grupo. Não se sentem também responsáveis pelo projeto político-pedagógico daquela instituição que cada vez mais fica refém das mudanças políticas que ocorrem na cidade. Levados que são a se preocuparem mais com questões relacionadas a sua evolução funcional, negando-lhes o tempo de reflexão e construção de práticas coletivas, os professores sentem-se claramente isolados e com pouco ou nenhum poder político para resistir as transformações que a cada instante ocorre e que se pautam mais em interesses políticos do que pedagógicos.

O silêncio que havia encontrado na sala dos professores no primeiro dia em que cheguei ao Alcina já não possuía mais o mesmo significado. Aos poucos fui percebendo que o silêncio era sinal da presença do poder que vigia, seja pela figura sempre presente do prefeito (pela foto na sala dos professores ou por sua presença física), seja pela entrada, sem prévio aviso, de membros da direção da escola, do poder que está escola, no lugar, na cidade e que redefine e determina certas relações sócio-espaciais. Para além de uma leitura simplista da atuação 
dos professores e de suas práticas, a compreensão do significado daquele silêncio me permitiu compreender como as relações de poder estruturam as relações sociais na escola, interferindo nas práticas de alunos e professores e, contribuindo, em certa medida, para reprodução da estrutura de poder que encontramos na cidade.

Para muitos professores, principalmente aos mais antigos na profissão, resta voltar-se para dentro da sala de aula e ali cumprir a função para a qual foram designados, sem questionar, sem se perguntar a quem interessa que tais elementos sejam dessa maneira e não de outra. Isolados na sala de aula, pouco importa aos professores compreenderem as dinâmicas sócio-políticas que dizem respeito ao lugar no qual a escola, como espaço-social, está inserida. O lugar surge apenas como sustentáculo de determinadas relações que com o decorrer do tempo passam a ser encaradas como naturais, como próprias da dinâmica do lugar. O que ocorre, porém, é que esta concepção acerca do lugar, consciente ou inconscientemente, é reproduzido pelo professor em suas práticas cotidianas e contribui para a reprodução da mesma na forma como os alunos concebem o mundo e o lugar onde vivem.

Como dissemos, pensar o lugar, e as múltiplas intencionalidades que 0 configuram, não é apenas tarefa da geografia. É antes ação política e pedagógica no sentido em que possibilita aos homens compreenderem o contexto, histórico e geográfico, no qual suas ações se realizam. A compreensão do lugar é elemento fundamental para que uma educação que busque possibilitar aos diferentes sujeitos a compreensão dos seus limites e possibilidades possa se realizar. Ao se alienar do lugar, o professor aliena-se de sua própria prática e reproduz a lógica que o aliena. Sem a consciência do lugar não é possível a consciência do homem como sujeito da história, da geografia, da vida, que constrói em parceria com outros homens que aprende a entender também como sujeitos, portadores dos mesmos direitos e deveres.

Daí a importância da pesquisa feita a partir da escola: desvendar as múltiplas implicações que o lugar no qual a escola está inserida possui; possibilitar aos sujeitos que participem da construção da escola como espaço social; permitir aos sujeitos que se reconheçam agentes da escola e que se organizem para resistir a todo e qualquer movimento que queira implodir seu 
caráter público em favor de interesses privados. Repensar a escola espaçotemporalmente, implica em repensar uma série de elementos que dizem respeito a forma como a sociedade da qual a escola é causa, consequência e resistência, está estruturada. Para além de mera reprodutora da sociedade, como afirmavam alguns estruturalistas, a escola é também resistência. Para tanto, é fundamental que os seus diferentes sujeitos compreendam que a pesquisa é elemento essencial para se construir uma lógica pública da produção do conhecimento. Pesquisar é partilhar informações, descrever caminhos, definir ações, refletir coletivamente, sem hierarquias em relações aqueles que dela participam.

Uma outra escola, para outros conhecimentos: eis os desafios do novos professores-pesquisadores. Eis o desafio que nos propomos a enfrentar. Político e pedagógico, tal desafio é resultado da implicação do pesquisador que entre tantos caminhos optou pelo da Educação Básica e que nela vê possibilidades de uma transformação que nasce da terra, de baixo e que busca inverter a lógica da reprodução da miséria e da riqueza que até agora foi predominante.

\section{Entre o poder e o nada: a escola na periferia}

Como realidade em constante transformação, a escola se realiza a partir de múltiplas experiências. É uma no subúrbio, outra na periferia. Não são, porém, realidades antagônicas, sem nenhum ponto de contato. É da descrição e da análise destas formas e significados que assume a escola em diferentes lugares que surge a possibilidade da compreensão das continuidades e descontinuidades existentes entre estas realidades. A partir disto, nesta parte de nossa dissertação, buscaremos compreender as formas e significados que a escola assume em um bairro da periferia paulista. Diferente da pesquisa realizada em São Caetano do Sul, na qual nos situávamos no interior das contradições que permeavam os processos de seu desenvolvimento, neste nosso olhar terá um maior distanciamento, será um olhar estrangeiro, olhar daquele que, aos poucos, vai desvendando uma lógica que, a primeira vista, parecia-lhe tão estranha e sem 
pouco ou nenhum sentido.

O ponto inicial desta etapa da pesquisa se deu a partir de uma série de trabalhos de campos, realizados durante o segundo semestre de 2007, na EE Prof $^{a}$ Ruth Cabral Troncarelli, no Conjunto José Bonifácio (Itaquera II e III), na Zona Leste de São Paulo. Minha relação com tal unidade escolar iniciou-se no final de 2005, quando ainda era estudante de graduação em Geografia na Universidade de São Paulo. Em trabalho de campo realizado na disciplina de Teoria e Método em Geografia II, ministrada pela Prof ${ }^{a}$ Dra $^{a}$ Amélia Luisa Damiani, pude conhecer o trabalho desenvolvido na escola pelo grupo Alma de Teatro, bem como o projeto de urbanização da praça próxima escola. Foi, inclusive, o projeto de urbanização da Praça, que me levou a aproximar-me da escola. Foi por intermédio de Aldo, militante da questão urbana da COHAB há algumas décadas que conheci alguns dos sujeitos que aparecerão no decorrer desta pesquisa. Para entender, portanto, as problemáticas que envolvem esta pesquisa faz-se necessário uma breve descrição do projeto de urbanização da Praça Celso Furtado /Ocaruçu e a relação com a escola e os seus diferentes sujeitos.

O projeto da praça surgiu como idéia do grupo de teatro ALMA que começou a se organizar política e artisticamente, no final da década de 1990, início de 2000, na EE. Profa. Ruth Cabral Troncarelli. A idéia originária do grupo era desenvolver um trabalho de conscientização sócio-ambiental, principalmente relacionado à reciclagem do lixo do Conjunto José Bonifácio. Para tanto, o grupo desenvolveu um trabalho de apresentações teatrais nos apartamentos do Conjunto que visava possibilitar aos moradores a reflexão acerca dos impactos ambientais e sociais que determinadas ações podem causar. Devido a este trabalho, o grupo foi contemplado, em 2005, pelo Programa de Valorização de Iniciativas Culturais, da Prefeitura Municipal de São Paulo e com isso pode ampliar as apresentações e fortalecer o trabalho no Conjunto.

Deste fortalecimento das atividades do grupo e de sua constituição jurídica, surgiram novas reflexões sobre os caminhos de sua atuação no Conjunto José Bonifácio. O grupo já possuía experiências relacionadas à implantação e urbanização de praças no próprio Conjunto, mas foi a partir da parceria feita com Aldo, militante da COHAB desde a década de 1970 e conhecido na região pelo seu trabalho de urbanização de praças, que o projeto começou a ganhar outros contornos. Segundo o que próprio Aldo nos informou, o Projeto da Praça Celso 
Furtado - Ocaruçu vai além da mera urbanização de praças. Seu objetivo, como vimos, é pensar outro tipo de praça, outra concepção de espaço público que possa unir, em um mesmo lugar, áreas verdes, laboratórios de pesquisa, de ensino, arte e cultura. Para Aldo, o projeto representa outro momento de sua militância nas COHABs. Para além da construção das praças, visa à constituição da comunidade, das relações sociais que a permeiam. Segundo Aldo, é preciso pensar a praça como catalisador dos processos sociais necessários a transformação da vida nas $\mathrm{COHABs,} \mathrm{sendo} \mathrm{que} \mathrm{neste} \mathrm{processo} \mathrm{a} \mathrm{relação} \mathrm{entre} \mathrm{a}$ pesquisa e o ensino tem papel fundamental.

Segundo os idealizadores do projeto, o mesmo tem como intuito

propor uma forma de ocupação daquela praça que tenha como objetivo a articulação da comunidade no sentido da reapropriação simbólica e prática do espaço público. Neste projeto, a comunidade aparece como sujeito em seus diferentes seguimentos: diretores de escola, professores, alunos, estudantes universitários, moradores, igreja. (PROJETO DA PRAÇA CELSO FURTADO, 2006:1)

É interessante notar o grau de compreensão da importância do projeto no que se refere a sua capacidade de articulação da comunidade para a reapropriação do espaço público, conceito ainda muito distante da realidade da urbanização periférica. Na periferia, em certo sentido, o espaço público é concebido enquanto espaço vazio, desprovido de ações e de controle. É o lugar do terreno baldio, do descaso dos órgãos públicos e áreas de interesses dos grupos privados que vêem ali grandes oportunidades de criação de um processo de especulação imobiliária, diretamente relacionado ao adensamento urbano. $\mathrm{O}$ terreno baldio é, portanto, o signo do público na urbanização periférica.

As fotos a seguir apresentam uma caracterização da área, bem como dos principais problemas encontrados na mesma e que suscitaram a elaboração do projeto e a articulação de alguns grupos de moradores do Conjunto José Bonifácio. 


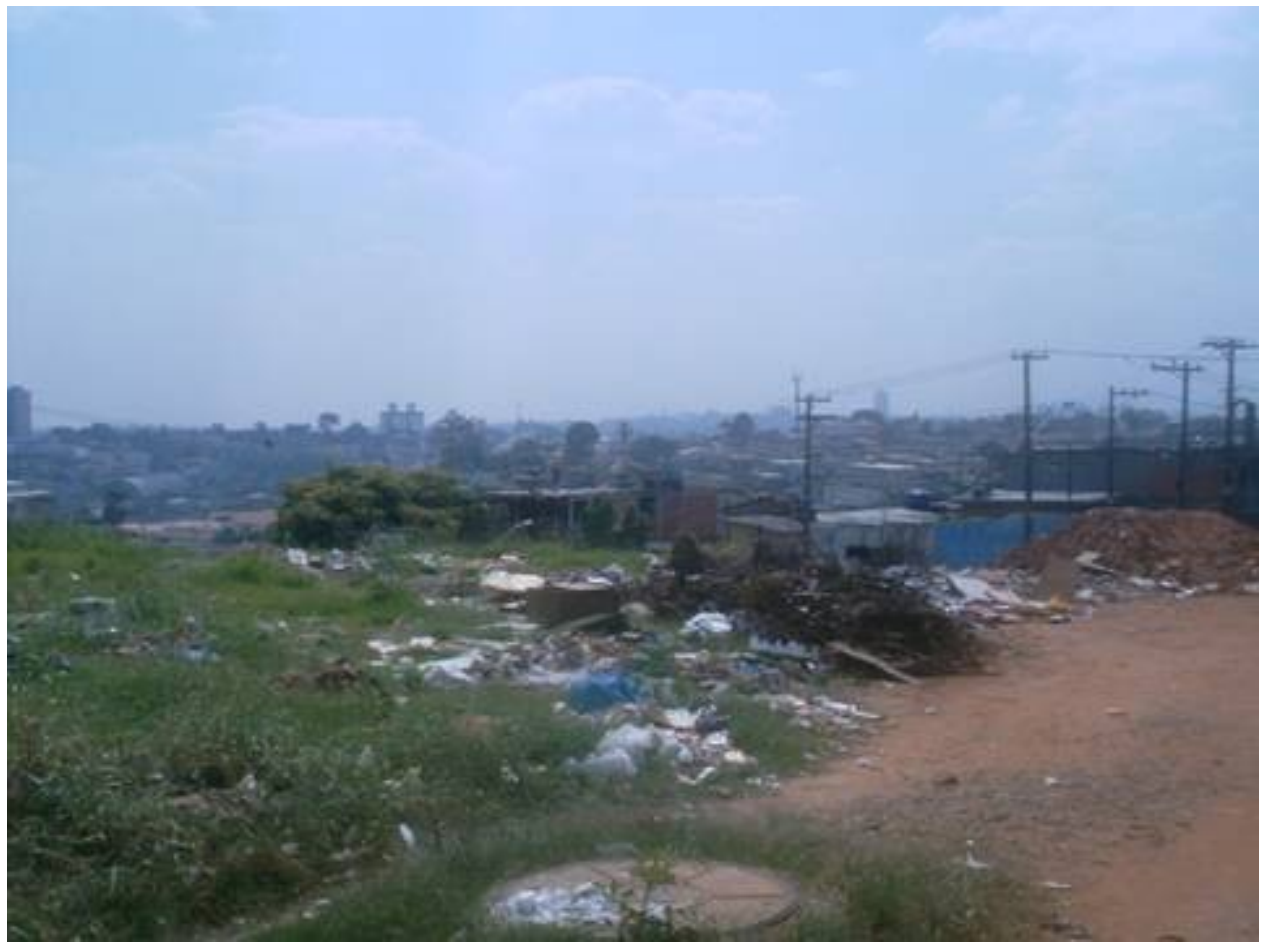

Figura 27: Vista geral da área escolhida para a implantação do projeto. Foto do Autor, março de 2006.

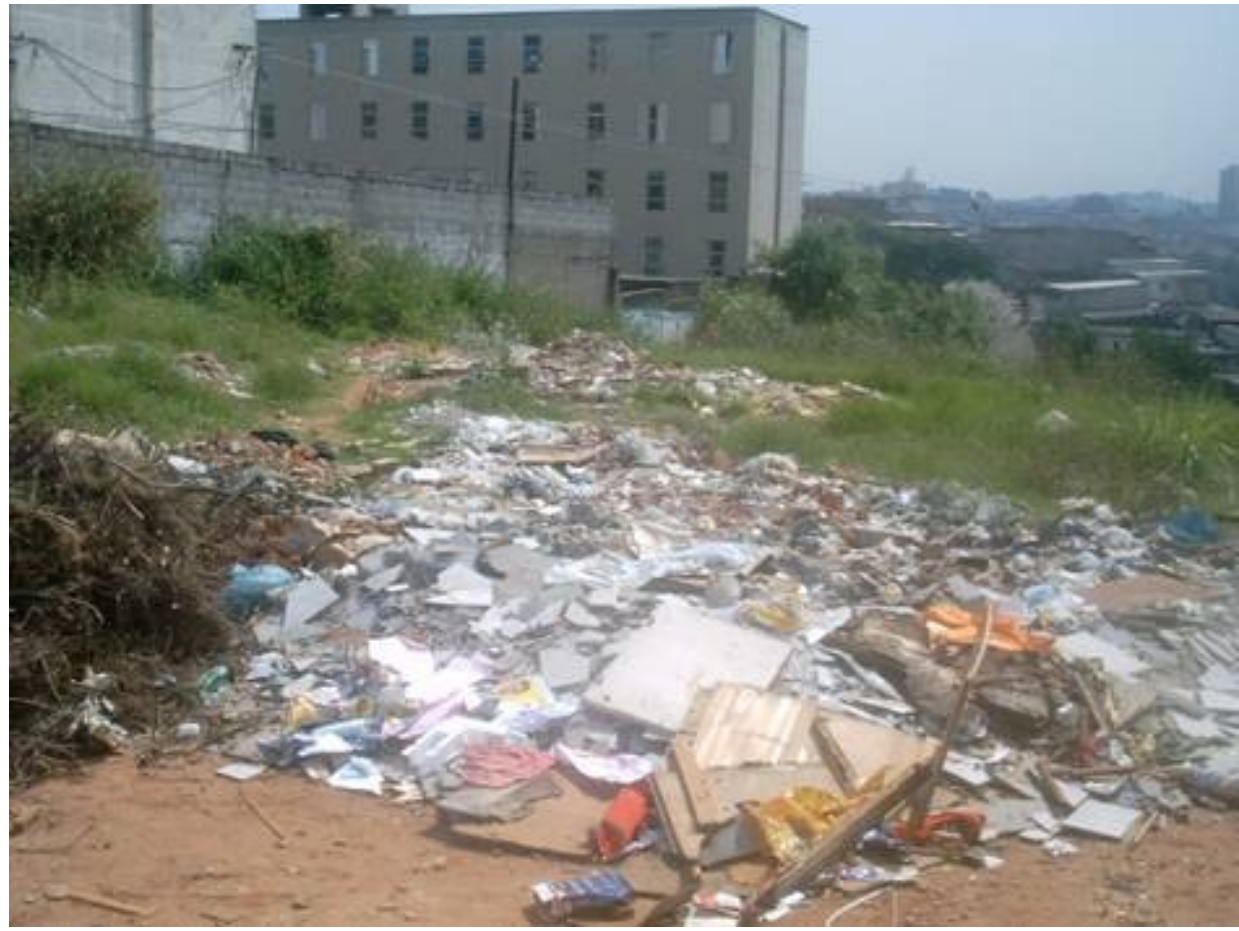

Figura 28: Atualmente, a área tem sido utilizada como área de deposito de entulho. Foto do Autor, março de 2006. 


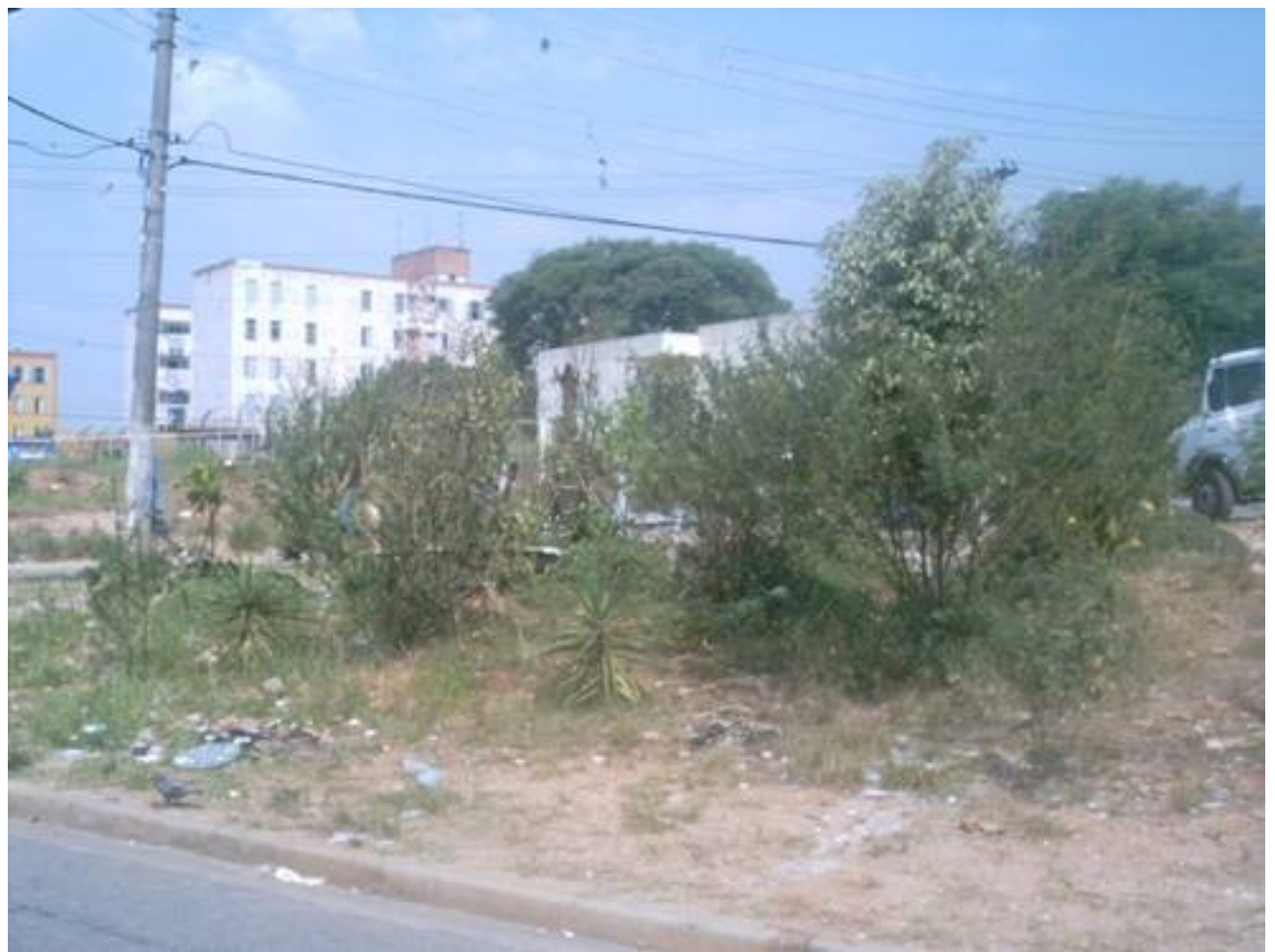

Figura 29: Algumas das árvores e arbustos plantados numa primeira tentativa de reurbanização da praça. Foto do Autor, março de 2006.

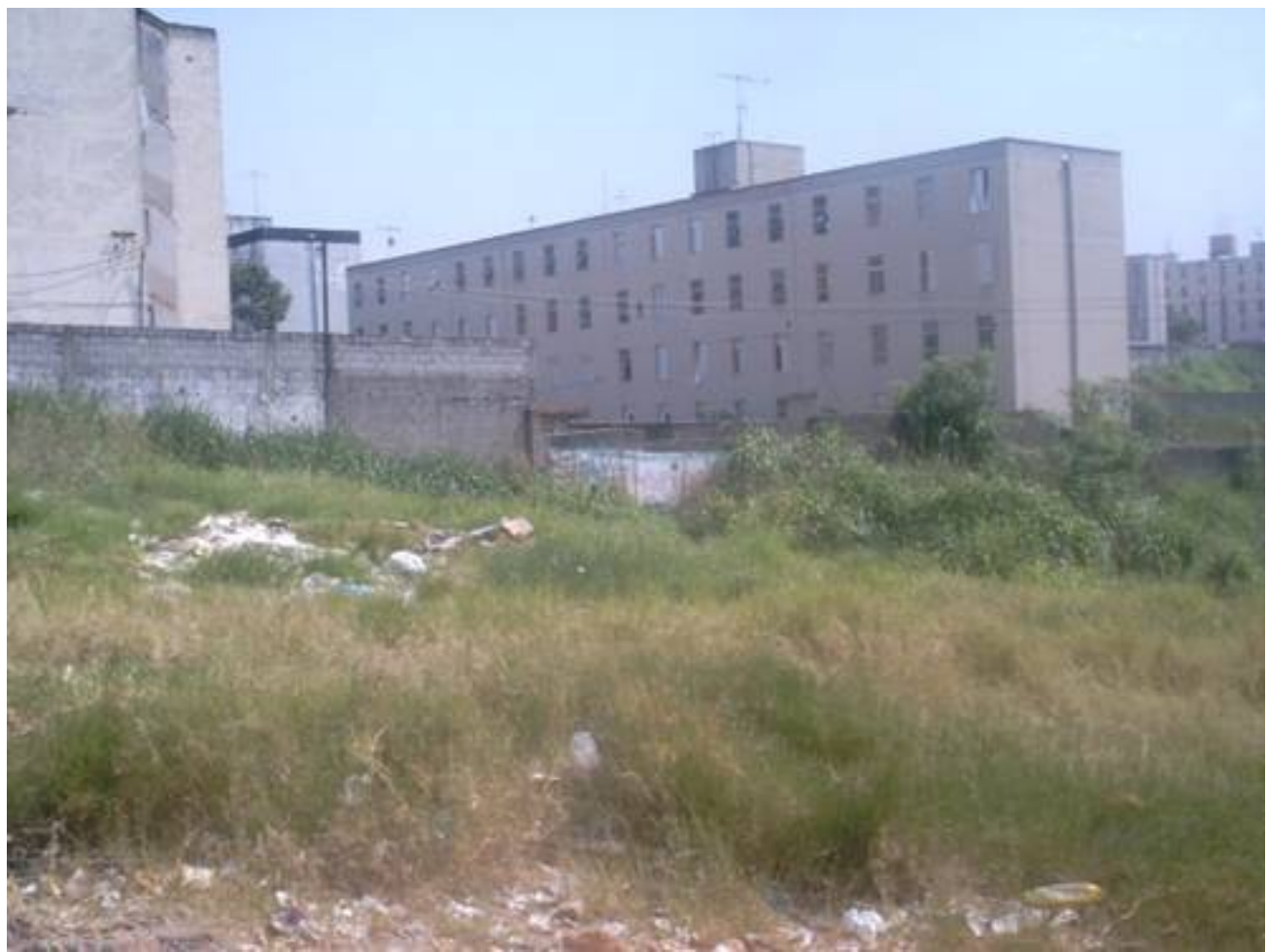

Figura 30: Outro problema atual da área é a falta de manutenção por parte do poder público. Aqui podemos observar a altura do mato que em determinadas épocas do ano toma conta de toda a área. Foto do Autor, março de 2006. 


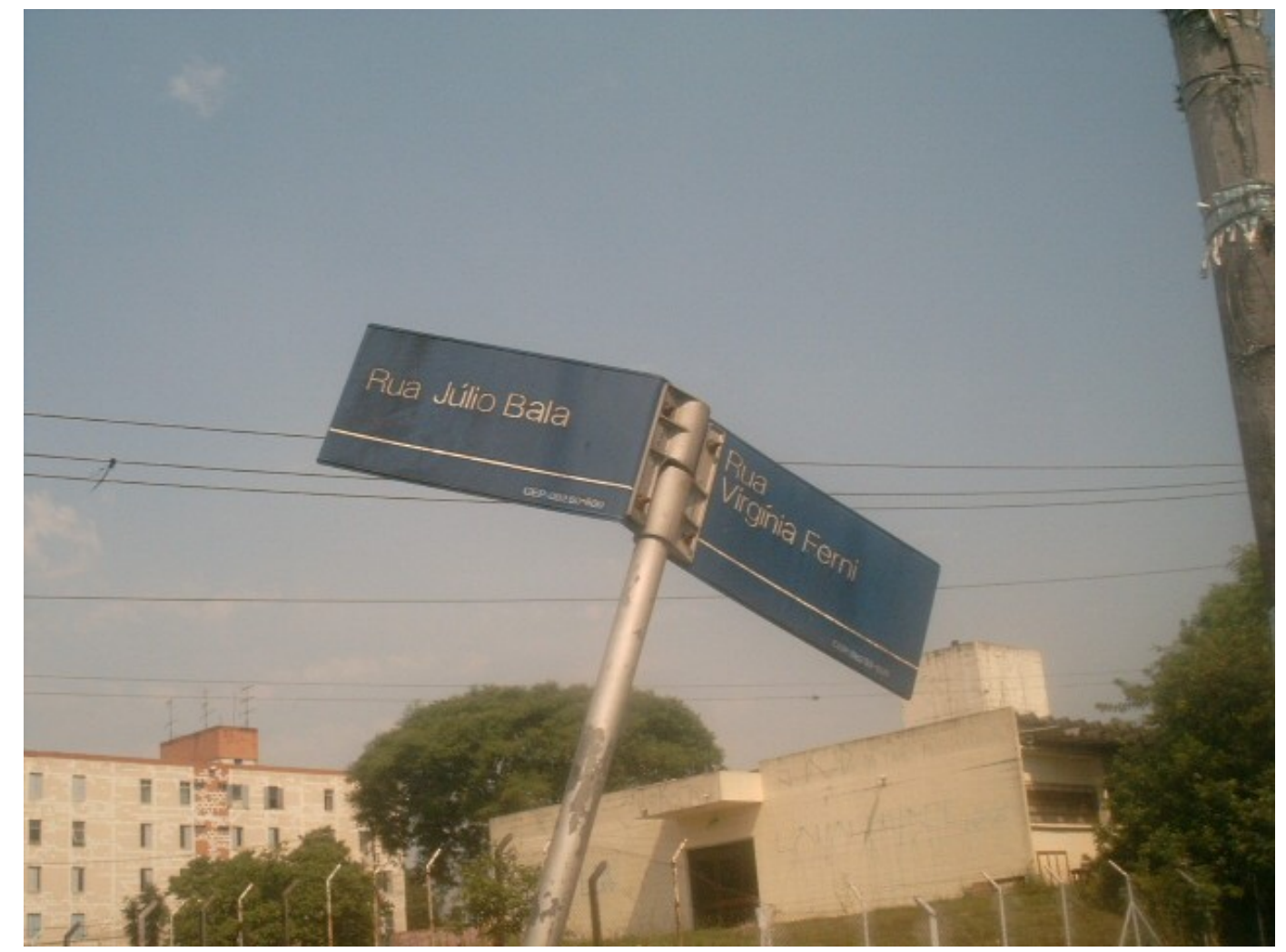

Figura 31: A placa caída indica o local exato da área escolhida para a implantação do projeto piloto. Foto do Autor, março de 2006.

Como pudemos perceber pelas fotos apresentadas, fica clara a concepção de espaço público como lugar do vazio, do terreno baldio, sem lei e ordem e, portanto, disponível a qualquer tipo exploração que leve em consideração princípios individuais sobre os coletivos. A presença de lixo e entulho, o avanço das construções de alguns prédios sobre as áreas, o uso das mesmas para estacionamento de carros e caminhões são exemplos deste processo de significação do espaço público como lugar do vazio que tem no Conjunto José Bonifácio uma de suas manifestações.

A reapropriação do espaço público, em certa medida, significa também, como aponta os propositores do projeto, sua ressignificação. É, portanto, mudar o significado do vazio, do terreno baldio, para o de lugar da construção coletiva de identidades e de resistência, que produz relações de comunidade, de pertencimento que, diferentes de outros processos relacionados à urbanização, não pré-existem a COHAB. Construir o espaço público, ressignificando-o resulta, também, em construir os laços que formam a comunidade a partir da resolução coletiva dos problemas comuns que dali surgem.

Em um texto anexado ao projeto, Aldo descreve os significados da praça e 
de sua relação com a COHAB José Bonifácio.

A região da praça Celso Furtado possui, como qualquer outra COHAB, uma gênese pouco comum: foi povoada repentinamente. Construiu-se o bairro e fez-se a ocupação. Numa manhã, uma população de uma cidade (de dezenas de milhares de brasileiros vindos da Bahia, de Minas, do Paraná etc.) forma de repente, um bairro dormitório. Não houve o tempo necessário para formar a história dos indivíduos, dos grupos, na sua participação nas lutas de reivindicação, ou na edificação de projetos de infra-estrutura como escolas de qualidade, hospitais, espaços para o lazer e a cultura. Isso aumentaria a proximidade entre eles, de modo a terem condições de praticar a vivência de vizinhança, enfim, criar laços de amizade no âmbito dos moradores, valendo-se do fato de necessidades comuns. (PROJETO DA PRAÇA CELSO FURTADO, 2006:3).

Como aponta Aldo, não houve tempo de formar o indivíduo neste processo de produção de periferias em massa. A praça surge como possibilidade de formação dos sujeitos, da história dos mesmos que resulta da apropriação do espaço para além do que está sendo concebido. O rompimento deste modelo de massificação do habitar, desta vida transformada em mera funcionalidade, em números a serem apresentados nos anuários sobre a questão urbana, passa necessariamente pela construção coletiva de outras formas de pensar e viver o espaço urbano. Para Aldo, a experiência da praça se configura enquanto uma destas possibilidades porque coloca em discussão as problemáticas comuns que envolvem os moradores da COHAB. Da identificação dos problemas comuns surgem as identificações pessoais, o reconhecimento do outro também como sujeito daquele processo. Surge, portanto, o indivíduo sujeito em meio a massa que se quer controlar.

Um elemento interessante relacionado à concepção do projeto diz respeito à forma como os moradores surgem como sujeitos do processo de implantação da praça. Segundo Aldo, a praça deve surgir de dentro dos prédios. Deve ser uma extensão, mesmo que com outras características, dos jardins que necessitam ser construídos nos condomínios. Deve ser lugar das hortas comunitárias, da sabedoria popular que substitui o remédio produzido pelas empresas farmacêuticas, pela valorização da medicina popular. Da mesma forma, deve nascer do jardim da escola, da horta comunitária que há tanto tempo 
desapareceu. A praça deve ser, portanto, o encontro destes múltiplos caminhos de resistência e de organização dos moradores da COHAB que para além do concebido propõem e realizam outras formas de vida.

No mesmo sentido, o papel da universidade na implantação do projeto da praça vai além da extensão universitária. A praça não deve ser, segundo seus autores, extensão da universidade, dos conhecimentos que dela vem, em uma relação verticalizada de poder e hierarquia. O conhecimento produzido na praça deve ser de outra ordem, deve partir do lugar, para a ele voltar e dele se expandir. Deve questionar a autoridade do conhecimento universitário, tornando-se assim um contrapeso ao caráter autoritário, porque monopolizante, de tal conhecimento. Sem perder o seu caráter universal, o conhecimento que se propõe ali produzir deve possibilitar outras reflexões dos moradores dos Conjuntos, seus principais sujeitos, acerca da vida e das contradições que a permeiam. Deve propor desafios e questionamentos fundamentais a superação de alienações relacionadas à própria concepção de espaço que ali se quis e se quer implementar.

Resgatar a força cultural, a sabedoria popular perdurada mesmo fora de centros acadêmicos, e agora, agregá-la, tornando o empírico ao alcance de todos, desde um doutor até um aluno primário, expelindo a barreira da genialidade do qual sem oportunidade nunca se tornaria tal e, com isso fomentar a influência do poder público, o nosso poder público.(PROJETO PRAÇA CELSO FURTADO, 2006:2)

Ainda segundo o projeto, desenvolvido em parceria com arquitetos da FAU - USP, a praça será dotada de um teatro de arena, de um laboratório de pesquisa popular, de áreas de desenvolvimento de medicina alternativa e, principalmente, como área de apoio para o desenvolvimento das atividades de ensino aprendizagem de professores e alunos da EE. Profa. Ruth Cabral Troncarelli. A localização da praça, há alguns metros da escola, possibilita esta articulação da mesma com a praça no sentido de sua reapropriação. O que está em questão, neste caso, é a proposta de uma outra forma de organização da escola. Enquanto, em muitos lugares, temos verificado um processo de fechamento em relação à comunidade e ao lugar, muito em decorrência do avanço da violência e do medo que ela provoca, o projeto visa uma reabertura da escola que passaria, 
dessa forma, a acolher o lugar e as contradições que implica, bem como seria acolhida pela comunidade da qual faz parte. Estabeleceria, portanto, uma outra relação com aquela determinada espacialidade, tornando-se assim referência, centralidade.

Seria, porém, um outro tipo de centralidade. Ao invés de impor ao lugar as normas e regras que dizem respeito a outras escalas geográficas de poder, estabeleceria um diálogo crítico e criativo com diversas instituições. Configurarse-ia, portanto, como ponto de contato, lugar da troca, da partilha e da construção coletiva de conhecimentos e significados a partir de problemáticas próprias ao lugar e a comunidade.

Para isso, porém, haveria a necessidade de mudança nas relações estabelecidas entre os diferentes sujeitos da educação com o lugar do qual fazem parte. É neste sentido, que o projeto da praça não pode ser compreendido sem sua relação com o projeto de escola. A praça e a escola são resultados de um mesmo movimento de organização popular que busca reorganizar o espaço para assim reorganizar a vida. As contradições que envolvem o projeto da praça em sua concepção e execução são semelhantes aquelas que dizem respeito à escola como espaço social, lugar das lutas coletivas, que envolvem grupos e organizações de moradores da COHAB. Em cada uma das ações, dos movimentos, dos processos que pudemos verificar em relação à implantação da praça e da construção de um outro modelo de escola, pudemos perceber que as contradições são resultado do movimento próprio da história e da geografia particular daquele lugar que expõe os limites e as possibilidades de um modelo de urbanização que concebe a cidade como privilégio de alguns e que busca na afirmação deste privilégio as bases para sua própria reprodução.

Não se trata de tarefa fácil. O avanço do mundo da mercadoria que rompe com os laços de sociabilidade humana e institui a relação entre coisas, pautadas na gramática econômica do capital tem se apresentado como principais empecilhos para o desenvolvimento do projeto. Além disso, a burocracia da escola e a falta de significados para muitos professores da importância do projeto resultaram em muitas idas e vindas que acabaram por enfraquecer o mesmo. Inserida na periferia, a escola tem erguidos muros em relação ao lugar e, em certa medida, o seu fechamento é a abertura propícia ao mundo do capital, ao mundo que reproduz o vazio repleto de mercadoria 
O projeto da praça traz para o interior da escola uma discussão que nem sempre seus principais sujeitos estão dispostos a enfrentar, que seja, como lidar com as questões do lugar, principalmente quando as mesmas apresentam-se complexas porque dizem respeito as contradições inerentes ao modo de produção capitalista que se materializam espaço-temporalmente? Estão a escola e seus múltiplos sujeitos dispostos a enfrentarem tais questões? Estão preparados para reconhecê-las? Ao se deparar com tais questões que implodem uma certa lógica repetitiva e burocrática e que, em certa medida, Ihe garante segurança e previsibilidade, a escola e seus diversos sujeitos se veem obrigados a reagirem, a romperem com as respostas prontas e os caminhos comuns. Vêemse obrigados a se reinventarem, a proporem soluções, a colocarem em dinâmica, em processos as questões trazidas pelo lugar. É neste momento, em nossa perspectiva, que estão as principais possibilidades de ressignificação do espaçosocial escola, da construção de outras sociabilidades para além da mera relação professor-aluno. Porém, como veremos a seguir, nem sempre os sujeitos da educação se permitem os riscos que as possibilidades traz. Muitas vezes, os caminhos da violência e do autoritarismo, que buscam manter as coisas aparentemente "seguras" são os mais escolhidos.

Neste sentido, o projeto de urbanização da praça Celso Furtado /Ocaruçu trouxe uma discussão importantíssima acerca do espaço urbano periférico e da escola inserida este contexto. Portanto, cabe aqui uma discussão acerca dos significados da periferia e da relação que ela estabelece com a escola. Sem esta discussão fica difícil compreender as questões pertinentes acerca da relação da

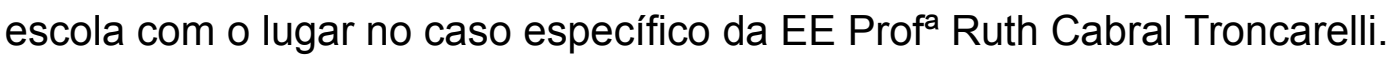

\subsection{Espaço e escola na periferia paulista}

De maneira geral, nas últimas décadas a cidade de São Paulo foi marcada por um processo amplo de expansão de sua mancha urbana. Para além de uma leitura demográfica, as razões que explicam tal dinâmica estão diretamente relacionados a expansão do modo de produção capitalista na cidade e sua relação direta com a produção/reprodução do espaço urbano. Verticalmente e horizontalmente, a expansão da urbanização paulista diz respeito ao processo de inserção do espaço urbano na lógica de reprodução ampliada do capital, 
tornando-se, ele mesmo, condição, meio e produto desta reprodução. De lugar de múltiplos usos sociais, a cidade torna-se fundamentalmente uma mercadoria, reduzida a lógica das trocas mercantis subordinadas a própria lógica do capitalismo. Tanto o subúrbio, como a periferia são momentos específicos resultantes desse processo de produção do espaço dominado pela lógica de produção capitalista. São momentos resultantes da necessidade constante de valorização e revalorização do espaço e da reincorporaçao destes valores e sobrevalores ao circuito financeiro.

No caso específico das periferias, seus processos de formação só podem ser entendidos se compreendermos que, ao se reproduzir, o modo de produção capitalista produz desigualdades que são, também, espaciais. É neste sentido que a relação centro-periferia tem sido dominante nos últimos séculos desde o surgimento do capitalismo e de sua expansão por diferentes áreas no mundo. $A$ relação centro-periferia, porém, não é a única existente: existentes múltiplas centralidades e periferias que conformam uma certa hierarquia relacionada ao poder político e econômico que realizam. Assim, se podemos falar de múltiplas centralidades hierarquizadas devido ao grau de importância econômica e política que possuem, podemos falar de múltiplas periferias, mais ou menos consolidadas, mais próximas ou distantes das centralidades principais do modo de produção capitalista.

Ao se reproduzir, portanto, o modo de produção capitalista reproduz sua desigualdade inerente e cria aquilo que, espacialmente, denominamos de periferias. De modo geral, as periferias podem ser definidas como áreas com pouca ou nenhuma infra-estrutura urbana (água encanada, rede de esgotamento sanitário), falta de regularização fundiária, pouca presença do Estado no que diz respeito aos investimentos necessários para que os direitos humanos sejam garantidos (escolas, hospitais, áreas de lazer). Porém, não se poder aplicar o termo excluídos para definir tais territórios da cidade. É exatamente por estarem incluídas na reprodução do modo de produção capitalista que tais áreas se formam e configuram. Suas morfologias não são resultantes da exclusão, mas processo diretamente relacionado a dinâmica de expansão do modo de produção capitalista. Ao se reproduzir, incorporando novos territórios a sua lógica de reprodução, ao mesmo tempo em que não garante as mínimas condições de apropriação coletiva daquilo que produz, o modo de produção capitalista 
"empurra" uma grande parte da população para as áreas mais distantes das centralidades principais da cidade. São nestas áreas, que Haroldo de Gama Torres denomina de fronteira urbana ${ }^{11}$, que as novas periferias vão se formando, resultando assim em um processo constante de reprodução da desigualdade do espaço urbano.

Porém, a produção da desigualdade na periferia não está apenas na dificuldade de acesso aos bens materiais. Segundo Milton Santos,

Morar na periferia é se condenar duas vezes a pobreza. À pobreza gerada pelo modelo econômico, segmentador do mercado de trabalho e das classes sociais, superpõe-se a pobreza gerada pelo modelo territorial. Este, afinal, determina quem deve ser mais ou menos pobre somente por morar neste ou naquele lugar. Onde os bens sociais existem apenas na forma mercantil, reduz-se o numero dos que potencialmente the têm acesso, os quais se tornam ainda mais pobres por terem de pagar o que, em condições democráticas normais, teriam de lhe ser entregues gratuitamente pelo poder público. (SANTOS, 1992:15).

Neste sentido, o processo de periferização do espaço urbano paulista é também resultante de um modelo de urbanização pautado na lógica do consumidor que acaba por substituir a figura do cidadão. As formas mercantis de relações tornam-se dominantes, sendo que, aqueles despossuídos da mercadoria dinheiro, têm negado os usos da cidade.

$\mathrm{Na}$ cidade, sobretudo na grande, os cimentos se dissolvem e mínguam as solidariedades ancestrais. Ali onde o dinheiro se torna a medida de tudo, a economização da vida social impõe uma competitividade e um selvagismo crescentes (...) Em lugar do cidadão surge o consumidor insatisfeito e, por isso, votado a permanecer consumidor. Sua dependência em relação aos novos objetos limita sua vocação para obter uma individualidade e reduz possibilidades dos encontros interpessoais diretos e enriquecedores, porque simbólicos em sua própria origem”. (SANTOS, 1992:16-17)

$\mathrm{Na}$ atualidade, o aprofundamento dos processos relacionados a produção desigual do espaço resulta em uma nova perspectiva de análise e interpretação

11 "Nesta perspectiva, a categoria fronteira urbana aponta para um tipo particular de periferia, com altíssima taxa de crescimento demográfico e precariedade no acesso a serviços públicos, particularmente saneamento".TORRES, HAROLDO DA GAMA. Fronteira Paulistana. 2004. 
da realidade urbana muito bem desenvolvida pela professora Amélia Luisa Damiani. Segundo a autora, vivemos o momento no qual o processo de urbanização, resultante da relação intrínseca com a expansão do capitalismo industrial e financeiro, tornou-se crítico. Para a autora, a urbanização crítica "é a impossibilidade do urbano para todos, a não ser que se transformem radicalmente as bases da produção e da reprodução sociais" (DAMIANI, 2004:30). Tal impossibilidade está também no fato de, que no momento atual do desenvolvimento capitalista, estamos vivendo a negatividade absoluta do trabalho, o trabalho como negação de toda possibilidade de realização da vida. Cada vez mais o trabalho como atividade criativa humana é substituído pelo trabalho sem significado, pelo trabalho abstrato que tem o fim em si mesmo.

Se no subúrbio o trabalho surge como positividade porque possibilidade de ascensão social, na periferia surge como dupla negatividade: não existe para todos e não possibilita nenhuma transformação a não ser a própria reprodução das condições mínimas de existência. Se no subúrbio é uma certa ética do trabalho que garante uma determinada coesão social, na periferia, há tempos, o trabalho perdeu sua centralidade. A ascensão social, a mudança de vida, de maneira geral, é vista a partir de outras atividades que substituem a ausência do trabalho como a carreira de jogador de futebol, de modelo ou o tráfico de drogas. Desta forma, como nos aponta Kowarick é preciso compreender o fenômeno das periferias como intrinsecamente relacionado as crises criadas e reproduzidas pelo modo de produção capitalista e que tem na espoliação do trabalho e do trabalhador seus principais elementos. Segundo o autor,

A periferia como fórmula de reproduzir nas cidades a força de trabalho é consequência direta do tipo de desenvolvimento econômico que se processou na sociedade brasileira nas últimas décadas. Possibilitou, de um lado, altas taxas de exploração de trabalho, e de outro, forjou formas espoliativas que se dão ao nível da própria condição urbana de existência a que foi submetida a classe trabalhadora. (KOWARICK, 1980:41)

Neste sentido, a urbanização crítica revela os limites deste modelo de sociedade, pautado no modo de produção capitalista e que tem na produção desigual do espaço um dos seus principais elementos. E é a partir destes 
elementos que buscaremos analisar a formação do Conjunto Habitacional José Bonifácio no qual está localizada a E.E. Profa Ruth Cabral Troncarelli. De maneira geral, o modelo habitacional proposto pela Companhia Metropolitana de Habitação (COHAB), na cidade São Paulo surge, ao mesmo tempo, como estratégia e mecanismo de reprodução ampliada do capital, naquilo que diz respeito as suas formas de reprodução no / do espaço. Inaugurado em 1980, o Conjunto José Bonifácio, conhecido também como Itaquera II e III, vem a ser um complemento do projeto de implantação de moradias periféricas na Zona Leste de São Paulo que tem como uma de suas primeiras ações a implantação do Conjunto Itaquera I, COHAB José de Anchieta. Tal modelo de produção deste espaço periférico difere de outras formas de ocupação da periferia porque tem na figura do Estado um dos seus principais agentes.

No caso do modelo de habitação do qual o Conjunto José Bonifácio faz parte, uma concepção de organização da cidade e de controle da vida está posta como elemento de organização da própria sociabilidade que se quer implementar. Não se trata apenas de garantir moradias para uma importante parcela da população pobre da cidade. Trata-se, sim, de definir normas, regras, formas de condutas e de sociabilidade, bem como direito ou não de acesso a determinados territórios da cidade. Tal modelo está diretamente relacionados com os princípios da arquitetura moderna, em um período de predomínio daquilo que Ermínia Maricato denomina de matriz modernista/funcionalista (2002). 


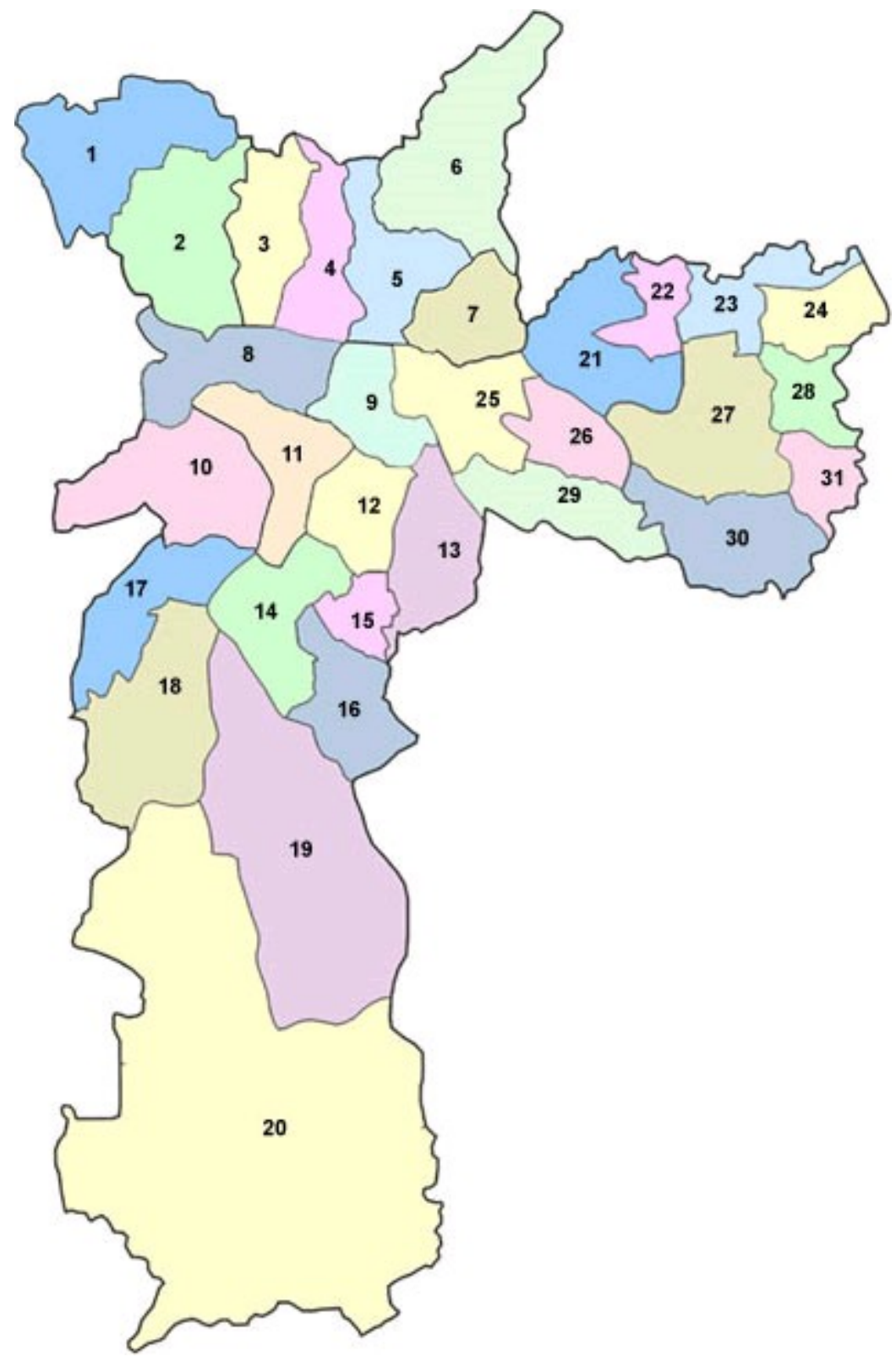

FiguRa 32: Localização da Subprefeitura de Itaquera, indicada pelo número 27 do mapa. Mapa sem escala. Fonte:

http://portal.prefeitura.sp.gov.br/secretarias/subprefeituras/subprefeituras/mapas/0 001/, acessado em 16/05/2009, às 9h14min.

Em um estudo sobre quatro COHABS na Zona Leste de São Paulo, Anderson Kazuo Nakano analisa os significados arquitetônicos e filosóficos dos Conjuntos Habitacionais, bem como suas implicações no modo de vida das populações dos mesmos. Segundo Nakano, as COHABs fazem parte de um intricado jogo de poder, de interesses políticos que estão diretamente relacionados com a questão que envolve a relação existente entre habitação e sociedade. Para o autor, é fundamental 
analisar os significados sócio-políticos do território, indo além da dimensão físico-espacial, desdobrando uma idéia da cidade como um campo de disputa de interesses atravessados pelos exercícios do poder compreendido como interações e atritos entre redes de relações que se chocam, se complementam, criando, destruindo e transformando as realidades da cidade (NAKANO, 2002:70)

Para além de uma imagem homogênea, primeira sensação daqueles que adentram a COHAB José Bonifácio, é preciso desvendar os diferentes interesses e significados que permeiam as relações sócio-espaciais existentes naquele determinado território, bem como compreender como determinados elementos sócio-espaciais surgem como lócus privilegiado para a manifestação destas relações. Em nossa perspectiva, a escola, como um destes elementos sócioespaciais que fazem parte da paisagem da $\mathrm{COHAB}$, surge como um destes lócus de compreensão das relações sócio-espaciais que define e redefine o lugar e seus significados. Voltaremos a esta idéia mais adiante.

Nos escritos de Le Corbuisier, um dos principais expoentes da chamada arquitetura moderna, principalmente na Carta de Atenas, o urbanismo surge como um dos processos que seriam responsáveis pela nova organização das cidades. Segundo o autor,

O advento da era da máquina provocou imensas perturbações no comportamento dos homens, em sua distribuição sobre a terra, em seus empreendimentos, movimentos desenfreados de concentração nas cidades a favor das velocidades mecânicas, evolução brutal e universal sem precedentes na história. O caos entrou na cidade. (CORBUSIER, 1993:32).

Caberia, portanto, aos urbanistas e arquitetos modernos traçarem, criarem e planejarem soluções para as contradições que o desenvolvimento da industrialização trouxe às grandes cidades. Caberia assim, a organização do Caos. Porém, ao não fazer a crítica nos termos das próprias contradições trazidas pelo modo de produção capitalista, a arquitetura moderna foi sendo, aos poucos, 
incorporada aos processos necessários a reprodução ampliada do mesmo. A arquitetura moderna e o urbanismo surgem, desta maneira, como elementos fundamentais da expansão capitalista no sentido em que possibilitam um maior controle social e um maior disciplinamento dos trabalhadores em todos os momentos de sua vida, não apenas naqueles restritos a experiência da fábrica. $O$ que faz a arquitetura moderna é levar a fábrica para todo lugar, impondo seu ritmo em substituição ao ritmo não-controlado da vida.

Em primeiro lugar, consideremos o urbanismo modernista, com seu desenho funcionalista de formas espaciais repetitivas baseados em uma racionalidade técnica condizente com uma noção unidimensional de cidade, como uma proposta alinhada com os princípios fordistas do capitalismo industrial baseados na busca pela expansão da produção e do consumo geradores de lucros extraídos na exploração da força de trabalho colocada a venda como mais um componente do sistema de mercadorias. Essa busca pela otimização do funcionamento social através das técnicas de planejamento traz embutidos objetivos disciplinadores e vem resumir a vida coletiva a simples lógica do mercado (NAKANO, 2002:72)

Neste trecho que acima descrevemos, o autor faz uma análise das relações existentes entre as propostas da arquitetura moderna e o processo de controle social e de expansão da produção ligados ao modo de produção capitalista em sua fase de acumulação fordista. A arquitetura moderna cria as condições para que a sociedade do automóvel pudesse se reproduzir de forma acentuada, sem o perigo de uma revolução social nascida da insatisfação das classes populares diante das péssimas condições de trabalho e de vida as quais estavam submetidas. De certa maneira, a arquitetura moderna pode ser compreendida como 
Uma arquitetura voltada para um projeto de produção de novas formas de habitar, um projeto das casas em série postas como máquinas de morar que transpõem a organização e a ambiência do trabalho nas fábricas e nos escritórios empresariais para os lugares de resistência (NAKANO, 2002:78)

A arquitetura moderna se sustenta, portanto, no discurso do justo lugar, da engrenagem social que tem seus princípios na obra do sociólogo francês Auguste Comte. A serialização da habitação cria a idéia da funcionalidade da moradia, do disciplinamento da vida e da reprodução da mão-de-obra, reduzindo o habitar ao habitat, a vida em suas múltiplas potencialidades, ao viver meramente biológico.

Ao mesmo tempo, segundo Damiani, afirma-se como processo de produção de uma sociedade de massas. A homogeneização da arquitetura, da produção em série de casas e conjuntos habitacionais, reduz a possibilidade da formação do sujeito a partir da relação que o mesmo estabelece com o morar. No projeto, o habitar se torna mera funcionalidade, mero aparato para que as condições de reprodução do capital possam, de fato, se realizarem. Cria-se, portanto, um processo de produção em massa de periferias, de negação da subjetividade que o próprio direito a cidade pressupõe. $O$ espaço urbano, neste modelo de habitação, é concebido enquanto momentos de passagens entre o trabalho e a casa, entre uma alienação e outra.

A proposta da arquitetura moderna, porém, pelo menos em discurso, surge com um caráter de salvação da humanidade. Os arquitetos modernos sentiam-se como quase heróis, capazes de apresentar os planos e as ações necessárias para a construção de uma sociedade mais justa e igualitária. Havia certa impressão de que os mesmos estavam para além do bem e do mal, do capitalismo e do socialismo. Vale ressaltar que muitos princípios da arquitetura moderna foram utilizadas em grandes reestruturações urbanas tanto em regimes capitalistas, como na antiga União Soviética (basta lembrar que o grande arquiteto modernista brasileiro ${ }^{12}$, Oscar Niemayer, se auto-denomina, até os dias de hoje, de comunista). Porém, a arquitetura moderna padeceu de seu próprio idealismo, de sua própria miopia. Padeceu de sua incorporação cada vez mais

12 Entre os arquitetos e urbanistas modernistas brasileiros esta sensação não foi diferente como nos aponta Ermínia Maricato: "É preciso reconhecer que a arquitetura brasileira plasmou uma imagem, um ideário colado ao projeto de subdesenvolvimento do país. Ela tinha as pretensões do projeto nacional: uma proposta de intelectuais que constituiria a redenção do atraso em que vivia o povo brasileiro". (MARICATO, 2002: 145) 
intensa na lógica de reprodução ampliada do capital. Daí a crítica a arquitetura moderna que parte desta constatação para propor um novo urbanismo para uma outra vida.

Neste sentido, é fundamental que compreendamos o projeto da COHAB, em sua concepção, também como resultado deste projeto de arquitetura moderna que, no Brasil, teve acentuado seu caráter autoritário nos governos militares das décadas de 1960, 1970 e 1980. Para além do objetivo de assegurar o direito à moradia, o modelo das COHABs implementado no Brasil, surge como uma expressão e uma exigência do modo de produção capitalista. As políticas implementadas pelo Sistema Financeiro de Habitação e o Banco Nacional de Habitação serviram menos para resolver o déficit de moradia e mais para fomentar a economia capitalista nos momentos de crise de sua acumulação no Brasil, visto que em grande parte, os recursos foram destinados ao financiamento da construção de moradias para as classes médias e altas. Da mesma forma, serviu para disciplinar o trabalho, evitando-se assim a revolução social, desmobilizando os movimentos sociais. Resulta destas políticas a construção do mito do sonho da "casa própria", objetivo a ser alcançado por todo e qualquer trabalhador brasileiro e que dependia, em grande medida, de sua inserção cada vez mais intensa no modo de produção capitalista e no modo de vida dali surgido.

Da mesma maneira, a COHAB representa também uma estratégia de expansão periférica do capital que resultou em um aprofundamento do processo de segregação sócio-espacial decorrente do fato de que as áreas escolhidas para a implantação da maioria dos conjuntos habitacionais localizavam-se distantes do centro da cidade e encontravam-se dotados de pouca ou nenhuma infra-estrutura. A escolha desta localização está diretamente relacionada com a crise de acumulação capitalista que atinge o Brasil a partir da segunda metade da década de 1970 e se espalha por toda a década de 1980. Como forma de escapar da crise e ao mesmo tempo apresentar um contra-partida social aos trabalhadores que viam cada vez mais seu poder de compra diminuído, devido a inflação galopante e o arrocho salarial, o Estado utiliza a estratégia de barateamento dos custos de implantação de conjuntos habitacionais. Para tal barateamento, opta-se 
por terrenos cada vez mais distantes do centro e, portanto, desvalorizados.

Dessa forma, esta segunda fase de implementação dos conjuntos habitacionais da qual o conjunto José Bonifácio ${ }^{13}$ faz parte, é marcada por um processo de redução total da moradia aos padrões mínimos, sendo tais padrões reduzidos ao direito de apenas ter um teto. O direito a cidade e a todos os elementos que dela fazem parte é veemente negado. Apesar de serem propostas no projeto áreas comerciais e institucionais, as mesmas foram sendo ocupadas posteriormente, pois dependiam, de um lado, dos interesses de comerciantes que não viam grandes oportunidades de lucros naquela região, e de outro, de ações do Estado para a implementação de escolas, hospitais, postos de saúde. Segundo Damiani, esta concepção da localização das COHABS contribui para o aumento do controle do tempo do trabalhador.

Agravam-se as distâncias entre o local de moradia e de trabalho, especialmente, tendo em vista a concentração de conjuntos na Zona Leste, que oferece relativamente menor quantidade de empregos, particularmente os industriais. $O$ tempo forçado - aquele tempo cotidiano, que também inclui as horas passadas nos transportes - tende aumentar (DAMIANI, 1993:114)

Neste sentido, como podemos perceber, a atuação do Estado na COHAB, como também nos aponta Nakano, é marcada ao mesmo tempo pela sua ausência e presença. Presença no sentido em que por suas ações, diretas e indiretas, em parceria com o setor imobiliário tenta controlar e disciplinar a vida por meio de imposições de normas e de estruturas arquitetônicas, capazes de delimitar, pelo menos em sua concepção, o permitido e o proibido. Mas é ausência também, no sentido em que não garante aos moradores dos conjuntos habitacionais nem mesmo aquilo à que se propõe na concepção do projeto. Não garante e não age no sentido de fomentar o direito a cidade. E é exatamente na lacuna deixada por esta ausência/presença do Estado que as transgressões e resistências ao espaço concebido como disciplinamento e controle social começam a se construir. Nos lugares deixados ao léu, sem a atuação do Estado,

\footnotetext{
13 “A COHAB José Bonifácio, localizada parte no distrito de Itaquera e parte no de José Bonifácio, foi sendo comercializado e ocupado no período entre 1980 e 1983. Segundo o censo demográfico de 1991 a área dessa COHAB era subdividida em 78 setores censitários com 20.562 domicílios, com 86247 habitantes, sendo que $78,32 \%$ foram identificados como casas e apartamentos em conjunto residencial popular. Do total de domicílios, 19,79\% são casas e 79,27\% são apartamentos" (NAKANO, 2002:102)
} 
os habitantes começam a se organizar em um processo que Damiani chama de construção de um espaço autogestionário, espaço vivido em contraposição ao espaço concebido. É nesta luta diária de construção destes espaços autogestionários que surgem os centros comunitários, as bibliotecas, as igrejas, as reivindicações por escolas, grupos de teatro, que, em certa medida, subvertem a ordem concebida para determinados lugares, redefinindo, portanto, funções, processos e estruturas.

Mas, seja como for, a vida se vinga, o espaço concebido, mesmo rudimentar, humaniza-se (...) O que parece igual ou similar, diferencia-se, com a configuração própria que the conferem seus moradores. Mesmo se o sentido primordial da ação for, até mesmo, a realização do espaço concebido (DAMIANI, 1993: 204).

A periferia é, portanto, lugar por se fazer. As relações não estão postas, nem são facilmente decifráveis e controláveis. As múltiplas formas de identidade e de sociabilidade se alteram constantemente. São das próprias necessidades de se viver no limite, nos extremos da reprodução da vida social e biológica, que os homens e mulheres da periferia se organizam e constroem estratégias, consciente ou inconscientemente, para o enfrentamento de tais situações. $O$ espaço da periferia é, portanto, revelador dos limites da urbanização crítica. Nele, as contradições são mais visíveis, mesmo que muitas vezes não reconhecidas e interpretadas. É lugar da transgressão representada pelo tráfico de drogas, pelo comércio informal e da resistência dos movimentos sociais, dos grupos de arte e cultura, entre outros.

É desta relação entre o concebido e o vivido, destas múltiplas contradições que afloram mais claramente na periferia que surge a escola como espaço social, como ponto de contato no qual estas diferentes sociabilidades encontram, articulam-se e se enfrentam. A escola na COHAB é, portanto, ao mesmo tempo, local da realização do poder estatal e da resistência ao mesmo, lugar da transgressão e ação crítica, representada pela resistência. Do disciplinamento da vida e de sua explosão em múltiplas possibilidades. É lugar da ausência que se faz presença através da burocracia estatal, das ordens e desordens que compõem as relações sócio-espaciais que ali ocorrem. É na escola também que os diferentes sujeitos da COHAB buscam construir e desconstruir identidades que 
ora são simulações, ora são construções nascidas das lutas e conquistas coletivas. Na COHAB, a comunidade não precede a escola. É antes resultado das relações que são também escola e que a constituem como espaço social das lutas e das relações de poder em suas diferentes escalas sócio-espaciais.

Em nossos trabalhos de campo realizados e a partir das conversas que tivemos com alunos e professores da E.E. Ruth Cabral Troncarelli, a escola, em certa medida, surge como lugar da ausência, sem regras, leis ou qualquer dispositivo legal de mediação. É a metáfora do terreno baldio, das áreas abandonadas, a espera de algum tipo de utilização. O próprio abandono e a sensação de que a mesma não se configura enquanto área comum é que faz da escola alvo fácil de interesses e estratégias privadas de apropriação. Ao mesmo tempo, existe uma certa visão de que é lugar externo, gerido e administrado por forças que escapam aos moradores e que podem ser resumidos na figura do Estado. Mas do que espaço público, a escola surge como lugar do Estado, no qual, em certas ocasiões o mesmo se faz presente, apesar de estar ausente em uma série de outros processos.

Por outro lado, esta visão da escola enquanto lugar do vazio abre oportunidade para que alguns grupos se organizem e proponham discussões acerca da forma como os espaços comuns da COHAB devem ser geridos. Da ausência deixada pelo Estado, tais grupos vêem a oportunidades de criação de outros modelos, propostas e conceitos de gestão e organização do espaço público. Tais grupos, que encontramos no interior da escola estudada, buscam trazer as questões pertinentes ao lugar para o interior da própria escola, preenchendo o vazio deixado pela ausência do Estado com a ação que só a amplitude da vida humana em suas múltiplas relações pode dar.

Tais questões, porém, não são simples e nem, muito menos, representam um consenso. Ao contrário, representam zonas de conflitos que vão desde de diferenças de concepção de vida a interesses e estratégias que dizem respeito a outras escalas geográficas de relação do poder. Um dos principais embates que envolvem os moradores da $\mathrm{COHAB}$ diz respeito ao que fazer com as áreas livres, que em muitos projetos encontram-se ainda não destinadas. A luta se dá principalmente contra o capital imobiliário em sua articulação com os diferentes órgãos do Estado e que visam transformar as áreas em novos condomínios, aumentando o adensamento urbano da região, sem que sejam feitos 
investimentos em infra-estruturas urbanas e sociais. Muitas vezes, a organização da comunidade para a construção de praças é uma das formas de resistência encontradas para se lutar contra este processo de adensamento que tende a piorar as condições de vida da maioria da população ali residente, além de resultar em um processo de expansão da especulação imobiliária.

Neste sentido, a EE Ruth Cabral Troncarelli surge como um dos lócus destas lutas em torno do espaço urbano que se realizam no Conjunto Habitacional José Bonifácio. Por ser a principal escola pública da região, as lutas sociais sobre o espaço urbano encontram ali importante local de acontecimento e revelam, portanto, as contradições acerca das relações entre escola e lugar.

Nos próximos parágrafos, apresentaremos a descrição e análise do processo e das contradições que verificamos e que dizem respeito à relação entre escola e lugar. Escolhemos descrever e analisar tal processo de dentro da escola, a partir do olhar daqueles que, em suas relações cotidianas, a constituem como espaço social, lugar das relações sociais que extrapolam seus limites e que são estão diretamente relacionados com o lugar social que a escola ocupa. Escolhemos a narração como forma de apresentação do texto para que possamos ampliar o foco de alcance da problemática, bem como possibilitar aos leitores uma gama maior de interpretações dos processos que envolvem a escola, sua função, seu significado em sua inserção na COHAB II.

Acreditamos que dessa forma, ao utilizarmos uma descrição densa, feita a partir de dentro, as contradições, que poderiam passar despercebidas em um primeiro momento, podem ser retomadas quando da análise do texto, enriquecendo assim nossa capacidade de interpretação dos processos e significados da problemática analisada. Além disso, é também forma de dar voz aos diferentes sujeitos que participaram, direta ou indiretamente, desta pesquisa.

O texto será apresentado de forma contínua e foi discutido com os principais sujeitos que neles aparecem, como forma de reelaborar olhares e interpretações. Nele, nos concentramos nos detalhes que naquele determinado 
contexto e situação encontramos. É a partir dos detalhes e do seu pretenso caráter superficial que a interpretação da realidade e das relações e processos que dela fazem parte pode ser realizada, buscando compreender os discursos dos atores sociais em suas relações intrínsecas com o lugar do qual são causa e consequência.

Ao invés de soluções mágicas para os problemas da escola, o que pretendemos com este exercício de campo é compreender a escola naquilo que ela possui de mais particular. Toda solução mágica, nascida principalmente de fora, é a revelação de que ainda a escola é pensada como homogênea e portadora dos mesmos processos independente de onde esteja e de quem dela faça parte. A escola não está dada, assim como não está a sociedade e nem os homens, em suas particularidade e generalidades. 


\subsection{O olhar de dentro: a praça e a escola na perspectivas dos sujeitos da educação.}

\section{0/08/07 - E.E. Prof ${ }^{a}$ Ruth Cabral Troncarelli - COHAB $\|^{14}$}

É final de tarde de uma quinta-feira chuvosa. Dirijo-me a COHAB II. Na cabeça, uma série de dúvidas e indagações. O que me traz ali é a tarefa de acompanhar o trabalho de um professor de filosofia na periferia da zona leste de São Paulo. Logo adiante, falarei mais dele. Antes, é preciso transformar em palavras as primeiras sensações que tenho ao adentrar a COHAB II, situado no extremo leste da cidade de São Paulo. Apesar de algumas visitas feitas anteriormente, a sensação que tenho é a mesma daquele que se aventura pela primeira vez em um lugar desconhecido, novo, estranho. Apesar de ter nascido também na periferia de São Paulo, meu lugar é outro, o mundo no qual me sinto seguro porque conhecedor daquilo que me rodeia encontra-se distante dali. Tento entender o que está acontecendo. Uma sensação de náusea toma-me o corpo.

\footnotetext{
14 Durante seis meses, realizamos uma série de trabalhos de campo contínuos com o intuito de descrever, analisar e compreender as relações sociais no interior da escola EE. Profa Ruth Cabral Troncarelli, principalmente aquelas relacionadas com o processo de implementação do projeto da Praça Celso Furtado - Ocaruçu. O que se segue abaixo é uma descrição detalhada dos trabalhos de campo. Em nossa perspectiva, acreditamos que a apresentação do texto abaixo, resultado da elaboração de nosso caderno de campo é elemento metodológico fundamental para uma melhor compreensão das relações sociais que tem na escola o lugar de suas realizações.
} 
Sinto-me desprovido de referências. A homogeneidade da paisagem confunde-me a visão. Por mais que ande, pareço estar sempre no mesmo ponto. Em cada canto, em cada janela aberta, em cada fresta de luz um olhar estranho parece me vigiar. Uma sensação de insegurança toma-me o corpo e procuro incessantemente um lugar para me esconder.

Paro em uma padaria para tentar respirar e resgatar um pouco do fôlego que esta estranha sensação me levou. O som alto rompe o silêncio daquela tarde na COHAB. Em minha frente, motoristas e cobradores de uma linha de lotação discutem sobre o resultado do futebol. $\mathrm{O}$ som de suas vozes é mais alto do que o som da música. Uma estranha música de estranha melodia. Até aquele momento, tudo me parece estranho. Já havia lido muito sobre a $C O H A B$, sobre o seu processo de formação, sobre os seus significados. Mas ler sobre a COHAB é diferente de nela estar. Aos poucos descubro que nada sei sobre aquele lugar.

Peço um café, sento e inicio minhas observações. Aos poucos, começo a me recuperar. Observo as diferentes paisagens que me rodeiam. Viajo em seus detalhes, em suas formas, procurando algum sentido, alguma conexão que possa me permitir entender aquilo que quero compreender. A paisagem da COHAB me causa um certo estranhamento. Há pouca luz nas ruas. Janelas abertas das quais feixes de luzes escapam são alguns dos poucos focos de luminosidade que permitem que a noite, que aos poucos vai tomando a imensidão do céu, seja vista. A chuva deve ter obrigado os moradores a se abrigarem em suas casas. As $18 \mathrm{~h} 40 \mathrm{~min}$, as ruas e avenidas da COHAB são ocupadas por um angustiante vazio. "A imensa periferia murmura uma imensidão de vozes" me disse uma vez Fabiano, professor de filosofia do Ruth. Procuro atentamente escutá-las. Mas há um silêncio, naquele momento, nas ruas da COHAB. Logo em frente à padaria, encontra-se a Escola Estadual Profa. Ruth Cabral Troncarelli. Observo-a por alguns instantes. Poucos alunos aguardam na porta o momento de ser liberada a entrada. Motoqueiros começam a chegar e a passar em alta velocidade. Em suas idas e vindas trazem e levam garotas. Algumas, com material escolar na mão, decidem não assistir aula naquela noite e partem com os motoqueiros. Outras recusam os convites feitos e que só terminam quando a menina decide adentrar a escola. Não sem antes, porém, ouvir uma série de ofensas do motoqueiro deixado para traz. 
Pago a conta do café que tomei pela metade e decido ir em direção a escola. Por enquanto é em vão tentar escutar as vozes e os murmúrios. Estou ainda totalmente surdo para escutar a COHAB. São 18h40min. As aulas começam às $19 \mathrm{~h}$. Tenho, portanto, algum tempo para as anotações iniciais.

Entro pelo estacionamento dos professores. Atravesso uma imensa porta de ferro verde, já um pouco enferrujada pelo tempo e adentro o hall. Recémreformado, dá aos visitantes uma primeira impressão de acolhimento e de organização que uma observação mais atenta e demorada logo vem desconstruir. O piso da entrada da escola lembra-me um grande tabuleiro de xadrez. É revestido de pedras de mármores, em uma intercalação de duas cores, preto e bege. O piso reflete a luz do corredor que liga dois pontos da escola: de um lado, uma sala de computação, muito bem estruturada e que foi resultado de uma parceria da escola com a empresa norte-americana de microprocessadores INTEL; do outro, um anfiteatro com capacidade para 100 pessoas. Esta área da escola é ainda completada pela sala dos professores, da coordenação pedagógica, da direção e a secretaria. Outro portão e uma grade de ferro separam esta área do restante da escola.

Vejo poucos professores. Descubro logo depois, na conversa com uma aluna, que eles chegam bem próximo do horário das aulas. Chegam apressados. Carregam materiais de outras escolas, de outros lugares, de outros mundos. Correm para a sala dos professores. Poucos andam pela escola. Aguardam, nos minutos que thes sobram para o descanso, o sinal que avisa que mais um novo período de suas jornadas de trabalho está se iniciando. Os professores "do Ruth", como popularmente a escola é conhecida, estão inseridos em uma triste realidade que marca as condições de trabalho da maioria dos professores brasileiros. Submetidos a baixos salários são obrigados a exercerem a função em duas ou mais escolas, acumulando assim cargas horárias que chegam a 60 horas-aula por semana. Esta situação resulta em uma vivência cada vez menor e menos significantes dos professores com o ambiente escolar e com a comunidade na qual determinada escola está inserida. Pouco vivem a escola, seu lugar, suas contradições. A escola, talvez, seja, para eles, apenas um ponto de passagem, mais um momento de um dia marcado pela repetição, pela rotina e pela velocidade incessante das tantas horas-aulas ministrados, muitas vezes, sem 
sentido nem significado.

Deixo o hall e caminho em direção ao pátio central. A paisagem da escola se altera radicalmente. O piso de mármore dá lugar ao cimento e a luminosidade do corredor é substituída por uma semi-escuridão que parece lembrar uma tarde de outono no momento em que o crepúsculo se anuncia. Bancos quebrados, banheiros mal conservados, grafite e pichações. Grades e mais grades separam o pátio do resto da escola, como se este se configurasse em um lugar de recolhimento, em uma verdadeira geopolítica da conduta, do movimento. Existem quatro grandes áreas comuns, com árvores e um pequeno jardim que ficam fechadas aos alunos e professores. No pátio, há um pequeno palco, no qual, acredito, devam ocorrer algumas apresentações de música e teatro. Banheiros, uma cantina e uma cozinha completam a organização espaço-temporal do pátio. Nas paredes, cartazes sobre os mais variados assuntos: vestibular, alfabetização de adultos, trabalhos de alunos. Por meio deles descubro que na escola ocorrem dois projetos em parceiras com instituições externas.

Um deles, a Escola do Possível, em parceria com a USP ocorre há mais de dois anos na escola e conta com a atuação de estagiários no desenvolvimento de atividades pedagógicas. Outro, o NEPSO (sigla de Nossa Escola Pergunta Sua Opinião) é uma parceria com o instituto Arthur Montenegro (integrante do IBOPE) e com a ONG Ação Educativa. Este projeto busca desenvolver com alunos atividades pedagógicas que façam uso das metodologias da pesquisa de opinião como forma de compreender fenômenos que ocorrem na escola e na comunidade. Anoto em meu caderno: "preciso saber mais sobre o desenvolvimento destes projetos". Antes disso, porém, continuo a minha observação inicial.

Por ser tratar da principal escola da COHAB II, o Ruth já foi alvo de uma série de parceiras com órgãos públicos e privados. Já abrigou em suas salas um cursinho pré-vestibular organizado pela USP e possui um laboratório de informática montado a partir de uma parceria com a Intel.

É nesse laboratório que trabalha Agnes, uma das alunas de Fabiano. É ela que me recebe na escola. Agnes está no segundo ano do Ensino Médio e pretender seguir a carreira de professora. No ano passado, foi convidado por Fabiano a assistir algumas reuniões de professores (HTPC) e saiu bastante desanimada. "Eles só falam mal de tudo, parecem infelizes com o que fazem" 
desabafou em uma das muitas conversa que tivemos. Porém, mesmo após estas reuniões, Agnes manteve sua disposição de ser professora. Tanto que aceitou o convite para dar aulas de informática para os alunos do Ensino Fundamental. Junto com mais quatros alunos do Ensino Médio, Agnes compõe a equipe responsável pelo desenvolvimento de atividades de informática com os alunos do período da tarde.

Pergunto-Ihe como tem sido a experiência. "Um pouco complicada. Outro dia, chamei a professora para conversar com a sala que estava fazendo muito barulho e fiquei assustada com o que ela falou. Ao invés de conversar com os alunos, ela apenas gritou e disse que não tinha mais jeito. Depois desabou em voz alta: dizem que eu não tenho pedagogia, mas não existe pedagogia para bicho, e saiu. Fiquei sem saber o que fazer", relatou. Segundo Agnes, a relação mais difícil é com os professores que, em sua opinião, estão desmotivados e parecem não gostar do que fazem.

Faltam cinco minutos para começar a aula. Fabiano chega. Pede desculpas e se dirige rapidamente ao banheiro. Quase não consigo falar com ele. Fico sentado esperando-Ihe. Agnes volta com um livro de Marx na mão. PerguntoIhe o que está achando do livro. "É um pouco difícil" afirma, "principalmente aquela parte que ele fala de espírito e matéria. Você sabe o que ele quer dizer com isso?". O sinal toca antes que eu possa pensar na pergunta.

Um barulho ensurdecedor. Um a um os alunos vão entrando na escola. Passam rapidamente pelo Hall e se dirigem ao pátio central. Em instantes, o pátio está repleto de jovens e adultos que buscam, naquela noite, naquela escola, alguma coisa que ainda não compreendi o que seja. Por que estão ali, quais são os seus desejos, suas intenções são perguntas que ainda passam longe de serem respondidas e que só assim serão quando feitas a quem interessa, que seja, os milhares de jovens que diariamente, apesar de tudo, frequentam as escolas públicas de todo o país. A imagem daqueles jovens reunidos no pátio trouxe-me uma sensação dual e contraditória ao mesmo tempo. Sinto alegria e tristeza. É como se eles estivessem ali esperando alguma coisa que sei que talvez nunca venha. Como professor, esta sensação me destrói. Destrói-me porque expõe os limites de nossa profissão submetida a situação de abandono e degradação. Enquanto olho para o pátio, um aluno passa e me cumprimenta. Pela suas roupas, percebo que está vindo direto para o trabalho. Naquele simples 
gesto, naquela tentativa de contato penso em tudo o que ainda não foi dito sobre a educação e que o excesso de burocracia tem impedido de vir a tona. Penso nos milhares de jovens que esperam da escola aquilo que um dia se sonhou que ela deveria dar. Penso nos discursos vazios e nas promessas feitas sem nunca se pisar em um chão de escola. Penso naqueles jovens que mesmo sem saberem são cobaias daqueles que acreditam que educação se faz do gabinete, sem envolvimento, sem paixão.

De repente, Fabiano sai do banheiro. Está com o cabelo raspado, o rosto e as mãos pintadas de azul. Veste uma camisa branca e uma calça marrom. Sua saída repentina assusta os últimos alunos que adentram a escola. A imagem do professor Fabiano alterada desta maneira cria um certo estranhamento nos alunos que acabam por alterar a rotina da passagem quase despercebida pelo hall. Comentários e sussurros preenchem os vazios da escola. Ninguém parece compreender. Confesso que meu susto foi gigantesco ao ver Fabiano saindo do banheiro daquela maneira e que demorei muito tempo para começar a entender o que estava acontecendo. E acho que aqui cabe uma explicação sobre o fui fazer ali, naquela noite.

Há uma semana, Fabiano em parceria com a professora Mônica, de geografia, desenvolvem uma peça de teatro com o intuito de fomentar, entre os alunos, a discussão sobre o capitalismo e quais as intervenções possíveis para alterar esta realidade. Para tanto, Fabiano, em um diálogo profundo com os conceitos teatrais de Brecht quer desenvolver o diálogo com os alunos a partir do estranhamento que consiste em transformar aquilo que parece ser comum, por sua repetitividade cotidiana, em estranhamento, a partir de sua (re) situação, recontextualização. Neste sentido, Fabiano parte do pressuposto de que é necessário (re)situar a escola como instituição, questionando as suas bases, aquilo que é e o que poderia ser. Para Fabiano, resituar a escola configura-se como primeiro passo para se pensar os significados dos espaços da COHAB no interior do capitalismo, bem como possibilitar aos alunos um debate crítico sobre o lugar do qual fazem parte.

Dessa forma, seres estranhos percorrem a escola, incorporando diferentes metáforas. Tais seres provocam e são provocados por outros alunos que reagem das mais diferentes formas a esta situação estranha. Em outra visita realizada a escola, Fabiano havia me mostrado as fotos das apresentações anteriores. Nelas, 
os alunos aparentam estarem bastante assustados com toda a situação, incomodados, quem sabe com uma prática sócio-espacial que, em suas percepções pouco tem a ver com a escola, lugar da ordem e da disciplina.

Naquela noite, pude presenciar mais uma cena do espetáculo semanal. De longe, sem me fazer ser notado, sendo inclusive confundido como aluno novo e levado uma bronca da inspetora por estar fora da sala, acompanhei Fabiano até a sala de aula. Foi uma travessia demorada, interrompida tantas vezes por alunos que não conseguiam acreditar naquilo que estavam a presenciar. Achavam "ridículo, estranho, incrível" e mais uma série de adjetivos que eram pronunciados após um breve silêncio ou a um grito de horror frente à situação. Em seus gritos, aquela transgressão as normas, as práticas sócio-espaciais na escola parecia inconcebível. De um lado, os gritos dos alunos. Do outro, os olhares vigilantes dos outros professores, assustados e ao mesmo tempo enfurecidos pela confusão existente na escola. Não que aquela confusão, pelo menos em quantidade, fosse diferente dos outros dias "normais de aula". Mas aquilo era inaceitável: toda aquela confusão partia de um professor, daquele que deveria ser encarregado da ordem e do disciplinamento segundo as normas vigentes. Aquela transgressão de Fabiano, em nossa perspectiva, custava-lhe uma negação ao grupo do professores.

Finalmente, adentramos a sala: pintada de verde, quase não tem ventilação. Os vidros permanecem sempre fechados. Estão pintados de branco para que a luz do sol não possa entrar. À noite, isso pouco importa. A porta, verde também, só pode ser trancada por dentro. Uma lousa, verde, completa a monotonia da sala de aula na qual 12 alunos se dispersam naquela noite.

Fabiano entra e fecha a porta. Não diz nada. Lá fora, nos corredores, escuto o grito do inspetor que pede que os alunos entrem na sala. Pela continuidade do barulho, deduzo que tal pedido foi em vão. O barulho de fora da sala contrasta com o silêncio e a atenção que a cena de um professor pintado de azul pode causar. Todos os olhares estão voltados para Fabiano. Os primeiros comentários começam a surgir, rompendo enfim com o silêncio daquele ambiente. "Vim para um circo", reclama um aluno, inconformado com a situação que presencia. Um outro se levanta e resolve sair. Não diz nada. Apenas bate a porta. Os alunos começam a ficar impacientes com a mudez de Fabiano. O que era antes silêncio e atenção se transforma aos poucos em raiva e revolta. Fabiano 
começa então a escrever na lousa. O silêncio retorna. "1789". "Revolução". "Mudança". "Raspar a cabeça". "Loucura". O que estas palavras querem dizer? Qual sua relação com o que está acontecendo? Indago-me, tentando compreender tudo aquilo.

De repente, a voz de Fabiano rompe o silêncio, jorrando em frases a loucura que parece emanar da cabeça raspada e da face azul. Fala de instituições. De seus significados. Provoca os alunos. "Sou louco, mas o que é normal? É normal dar um visto no caderno, fazer um prova, copiar um texto da lousa, mesmo que nada disso sirva para nada? É isso a normalidade?" Os alunos querem entender a atitude do professor. Perguntam-Ihe a todo momento o porquê daquele ato. Não se conformam que um professor, símbolo fundamental de uma instituição, tenha agido daquela maneira tão distante da normalidade. Os outros professores também parecem pensar assim. Agem, predominantemente de duas maneiras: indiferentes e preocupados. Preocupados principalmente com o fato de que as coisas podem sair do controle. Mas quem controla quem na escola?

Com o passar da aula, os alunos se mostram cada vez mais irritados e impacientes com a situação. Fabiano se nega a dar respostas. Quer dialogar com os alunos. Quer que eles falem sobre o que pensam, sobre suas sensações. Os alunos querem apenas respostas. Negam o diálogo, talvez pelo fato de que poucas vezes foram chamados a fazê-lo. A falta de respostas de Fabiano faz a atenção dos alunos se dispersar e o barulho, antes restrito aos corredores, tomar conta da sala.

Bate o sinal. (Eles estão chamando) - vocês logo irão entender.

O mesmo ritual. Mudança de sala. Gritos de alunos. Expressões as mais variadas possíveis. No meio do caminho encontramos Mônica, professora de Geografia. Mônica tem sido a principal parceira de Fabiano neste trabalho de reinvenção da escola. É, porém, mais "comportada" que Fabiano. Isto talvez seja explicado pelo fato de ser professora há muito mais tempo do que Fabiano, que acabou de sair da universidade e vê na escola e na arte uma possibilidade de transformação política da sociedade. Acho que aqui é importante ressaltar que Fabiano se autodenomina um Anarquista. Isto talvez explique o fato de todo o seu 
trabalho girar em torno do questionamento das principais instituições nas quais se baseiam nossa sociedade. Sua concepção de escola parte, portanto, da concepção de mundo que possui sendo impossível desvincular os dois. Compreendo, portanto, aos poucos, no contato com Fabiano e Mônica que para entender determinadas ações de um professor preciso saber o que pensa e como entende o mundo e a escola.

Uma idéia surge do encontro casual entre Fabiano e Mônica: por que não juntar as salas para uma aula conjunta? A baixa presença de alunos naquela noite facilita a transição do plano da idéia para a prática. São agora quarenta alunos numa sala. Muito? Pergunto-me. O mínimo que os professores enfrentam numa noite comum.

Mônica inicia a aula. Fabiano permanece calado. Mônica fala do conhecimento, de suas intencionalidades, de seus interesses. Fabiano faz caretas e máscaras. A aula ainda está em ritmo de brincadeira. Os alunos parecem bastante descontraídos com aquela situação nada convencional. De repente, a voz de Fabiano interrompe Mônica. "Quero falar". Os alunos respondem com uma forte risada. Parecem não acreditar ainda naquilo que está acontecendo. Um aluno chama Fabiano de louco. Sem saber, oferece-lhe o tema da aula, o qual desenvolve muito bem. Fabiano conta a história dos hospícios, de que forma foram formados. "Os que não interessavam mais, que não mais serviam eram enviados para lá, para lugares distantes, para que os sãos não pudessem saber de suas existências", aponta Fabiano e complementa com a história de um louco que se masturba na frente de uma mulher. Os gestos de sua interpretação levam a sala ao delírio. As risadas parecem descontrair cada vez mais o ambiente da aula. Porém, percebo que os alunos ainda não compreenderam a tragédia que Fabiano e Mônica anunciam com suas fala. Sinto um certo incomodo. Quero falar, mas penso nas implicações desta minha intervenção. Estou jogando minha pesquisa fora? Devo me manter neutro como apontam muitos discursos científicos? Estou ali como um pesquisador distante apenas? Perguntas e mais perguntas rondam minha cabeça. A ansiedade é tão grande que não consigo alcançar uma resposta racional. Levanto-me. Dirijo-me até a mesa de Mônica e Ihe peço um giz. Ela parece não entender. Fabiano continua a falar. Com o giz na mão, caminho em direção a lousa. $\mathrm{Na}$ cabeça, as perguntas ainda não respondidas. Toco o giz na lousa. A resposta foi dada. Intervenho. "Não seria a 
COHAB um grande hospício?". Silêncio. Ninguém parece entender minha atitude. Muitos devem estar a se perguntarem: quem é este? Observo-os e vejo que seus olhos miram-me atentamente. Esperam que eu fale alguma coisa. Despejo na forma de palavras todos os sentimentos confusos que até aquele momento, a noite havia me propiciado. Após uma rápida fala, calo-me. O silêncio continua, rompido apenas pela voz de Mônica que cita uma música do Rappa que exemplifica bem o momento: "faltou luz, mas era dia, o sol invadiu a sala, fez da TV um espelho refletindo o que a gente esquecia".

Bate o sinal.

Novamente, mais duas classes são unidas para assistirem a aula de Fabiano e Mônica. Ainda tento entender as consequências de minha intervenção. Fabiano e Mônica me agradecem pelo que fiz na última aula, mas reitero minhas desculpas pela intervenção. Sinto-me bastante confuso. Nesta sala, a aula parece andar um pouco menos intensa. Os alunos estão mais dispersos. Porém, guardam atenção para alguns momentos. A conversa esquenta quando Mônica os questiona sobre por que a escola deve ser assim? "Porque sempre foi assim. Quando chegamos já a encontramos assim", responde um aluno. "Fomos educados a não ter dúvidas", constata outro aluno. "E por que continuamos assim?", provoca Mônica percebendo que a aula parece ganhar fôlego. "Porque não há nada para fazer. Já nascemos assim. Não adianta nada" desabafa um aluno. Silêncio. Fabiano retoma a palavra e fala do poder presente na escola. Fala das ordens e da instituição que ela representa. Fala do sinal, da voz que chama a levantar ou a sentar com momento e hora marcada. A voz de Fabiano é interrompida pelo barulho ensurdecedor do sinal. E neste momento, uma cena incomum acontece. Poucos alunos se levantam. "Vão. Eles estão chamando", provoca Fabiano. Os alunos parecem não saber como agir. O que fazer? Sentemse provocados. Aos poucos, meios sem graça, vão se levantado e saindo para o intervalo. Muitos estão em silêncio.

Fabiano e Mônica permanecem na sala e são abordados por duas alunas que querem agradecer e partilhar suas sensações sobre a aula. A conversa se estende em direção ao pátio. Observo apenas de longe. De repente, Mônica me chama para escutar a fala de uma aluna. Daiana aparenta uns 30 anos. Entrou na 
escola há pouco tempo. Ele me revela que as aulas do Fabiano e da Mônica mudaram a forma como ela observa as coisas. "Eu chego em casa e vejo coisas que antes eu não via" revela Daiana. Pergunto-lhe se essas coisas já estavam lá ou surgiram de repente. Ela pensa um pouco. "Acho que estavam lá". "E então, o que foi que mudou?". Silêncio. "Os olhos mudaram".

O final daquela experiência me deixa confuso. Sinto-me repleto de informações e ainda não sei bem ao certo o que fazer com elas. Os caminhos que percorri não foram aqueles que planejei percorrer. A experiência de campo me levou para lugares que ainda não havia conhecido no âmbito da pesquisa e da existência humana. Todas aquelas situações, toda a força de cada um dos atos presenciados naquela noite levaram-me a questionar verdades, conceitos, idéias que, como pesquisador, achava certas e inequívocas. Pude sentir, no exato momento de minha intervenção as implicações políticas e científicas que ela me trouxe, mesmo sem compreender ao certo ainda o que tais implicações significam. Não conseguia organizar as idéias. Havia anotado quase tudo em meu caderno de campo. Estava ansioso para transpor para o papel aqueles sensações que tanto me incomodavam.

São quase 22 horas. Os alunos estão no pátio. Fabiano e Mônica se dispersam em rodas de conversas, e aos poucos buscam responder a imensidão de perguntas feitas por alunos que, como eu, não tinham ainda compreendido o que estava acontecendo. Sem atrapalhar muito, despeço-me de Fabiano e Mônica, prometendo voltar na próxima quinta. Saio sem ser notado. Atravesso o portão verde de ferro e me perco na imensidão da COHAB.

É uma noite fria e silenciosa. Uma neblina intensa impede que muita coisa seja vista. Apenas com muito esforço, atravessando a neblina, o olhar é capaz de observar a lua, que ilumina uma das tantas janelas que entreolham a $\mathrm{COHAB}$.

\section{4/09/07 - E.E. Prof ${ }^{a}$ Ruth Cabral Troncarelli-COHAB II}

Após duas semanas, retorno a COHAB. Trago em minhas mãos a transcrição do meu caderno de campo com os relatos da semana anterior. Quero, na medida do possível, compartilhar as informações ali descritas com Fabiano e Mônica, ouvir suas opiniões, discutir pontos de vistas, dialogo com aqueles que considero também sujeitos desta pesquisa. 
Ao adentrar a escola, percebo um imenso silêncio. Aos poucos desvendo os motivos do mesmo: a escola esta vazia. O passeio a algum parque de diversão foi o responsável por aquela ausência. Dirijo-me a sala dos professores. Em seu interior, alguns professores conversam, outros assistem televisão, outros aproveitam a falta dos alunos para colocar em dias as questões burocráticas que envolvem a escola, principalmente aquelas que dizem respeito ao preenchimento do diário. Indago-Ihes sobre onde encontrar Fabiano e Mônica. Um professor, de maneira ríspida, aponta-me o teatro. Agradeço e saio, sem ainda compreender o motivo de tal tratamento.

Alguns metros a frente, após atravessar uma porta de madeira que leva ao anfiteatro, encontro Fabiano e Mônica. Eles estão imersos numa pilha de trabalhos e diários. É quase difícil encontrá-los em meio a tantos materiais. Um pouco depois descubro que se trata de uma pesquisa realizada pelos alunos que tinha por objetivo desenvolver uma reflexão sobre o que havia ocorrida no mês. Eram pesquisas as mais variadas possíveis. Em sua grande maioria, cópias da internet, impressas de qualquer maneira, sem nem mesmo uma leitura prévia. A minoria se tratava de uma tentativa real de reflexão.

Talvez, por este motivo, Fabiano parecia um pouco chateado. Sem querer, porém, em nossa conversa, descobri que o motivo de sua chateação era outro. Após um mês de trabalho, buscando relacionar a reflexão sobre a sociedade atual, com a arte, a geografia e a filosofia, Fabiano havia criado uma série de animosidades com os outros professores. Segundo Fabiano, os outros professores o acusavam de ter desvirtuado o sentido da escola e principalmente de ter realizado tarefas incomuns sem a prévia comunicação. Em certo sentido, os professores se sentiam traídos por alguém que fazia parte do grupo deles. Uma coisa era os alunos se contraporem aos professores, buscando maneiras de boicotar suas aulas, de resistir. Outra coisa, era um professor realizar atividades que em certa medida, ridicularizavam a figura do professor. Em conversas com alguns professores e com a vice-direção da escola, o que eles não aceitavam era fato de Fabiano, em suas aulas, utilizar métodos nada convencionais que destruíam a imagem do professor. Para a maioria dos professores do Ruth, a imagem do professor se vincula a imagem de autoridade, de ordem, de disciplina. Pintar a cara de azul, raspar o cabelo, destrói, portanto, uma imagem que muitos tentam manter como principal estratégia de desenvolvimento de sua atividade 
profissional.

Neste sentido, Fabiano, desde o ocorrido na semana passada, considerado a gota d'água pelos outros professores, vivia numa situação de distanciamento. Já não frequentava a sala dos professores, nem os HTPC. Preferia passar as horas em que se encontrava fora da sala de aula com os alunos. Já havia sido chamado pela coordenação para uma conversa. Já havia exposto sua idéia, bem como seu fundamento pedagógico. Mas a situação parecia não melhorar. $\mathrm{Na}$ verdade, piorou. Em um dos HTPC Fabiano apresentou para os outros professores um vídeo que havia realizado com os relatos dos alunos. Neste vídeo, os alunos fazem críticas diretas a escola e aos outros professores, desvelando, em suas falas, contradições que a escola busca ocultar. Em uma das falas, uma aluna do $2^{\circ}$ ano do Ensino Médio, tece uma série de elogios ao professor Fabiano. Estes elogios são cortados, porém pela imagem de uma planta que cresce entre as grandes e que para aumentar de tamanho incorpora as grades sem saber o que está fazendo. Segundo Fabiano, seu intuito com o vídeo era abrir diálogos com os professores acerca das contradições na qual eles estão inseridos, buscando compreende-las. O que ocorreu, porém, foi exatamente o contrário disso. A maioria dos professores sentiu-se ofendida com o vídeo. Acharam que se tratava de uma forma de Fabiano desmoralizá-los frente aos alunos e também uma forma de o professor se autopromover. Após a apresentação dos vídeos, muitos professores se retiraram do HTPC, negando-se ao diálogo. Fabiano acabou sozinho na sala dos professores, sem ao menos justificar a realização do vídeo. Estavam postos os lugares que cada um dos sujeitos escolares assumiriam naquela relação de poder. De um lado, um grupo de professores que já trabalham há mais de 10 anos juntos e que possuem, mesmo que indiretamente, uma norma de conduta que deve ser por todos respeitado. Participar do grupo significa levar a sério e respeitar esta norma de conduta, mesmo que não se saiba ao certo o que ela significa. Do outro lado, um professor novato, pouco habituado com as relações de poder na escola e que buscou em seu trabalho dialogar criticamente com os outros professores. Talvez, faltou a Fabiano um pouco de "jogo de cintura", de compreensão das relações de poder nas quais ele mesmo está inserido. Fabiano queria incomodar, e assim o estava fazendo. A questão era saber até quando os outros professores aguentaria aquele incomodo. 
Naquela noite, indaguei Fabiano sobre o porquê não havia avisado aos outros professores acerca da atividade que realizaria. "Porque era exatamente esta a sensação que queria criar: a de incomodo. Como é possível não se incomodar com tudo o que acontece nesta escola. Como é possível aceitar que as coisas acontecem desta forma, sem se questionar. Se eu avisasse aos outros professores o que iria acontecer, o incomodo não teria ocorrido. Não desta forma. O que eles não compreenderam é que era fundamental que as coisas ocorrem desta forma". O que talvez Fabiano não esperava era a reação que sua atitude geraria na escola.

Pude perceber naquela noite que alguma coisa estava muito estranha. Aquele clima de animosidade parecia dominar os corredores da escola. Apesar de os alunos não estarem ali, a violência na escola, de outras formas, ocorria. 0 poder silencioso, o poder do olhar, da mútua acusação passava a dominar as relações que ali se estabeleciam. Percebia que Fabiano estava isolado. Mônica estava preste a abandonar o período noturno da escola. Havia conseguido um emprego em uma Universidade Particular. Restava a Fabiano suportar aquela situação.

No caminho de volta para casa, entre a sensação de estranhamento que aquela nova situação me trazia, um pergunta me incomodava: quanto tempo Fabiano aguentaria aquilo? Sem saber, a resposta estava mais próxima do que eu poderia imaginar.

\section{8/09/07 - E.E. Prof ${ }^{a}$ Ruth Cabral Troncarelli - COHAB II}

Retornei a escola, duas semanas após o último relato. Encontrei um Fabiano mais triste e mais "normal". Suas aulas ocorriam agora na sala de aula, porta fechada, sem corte de cabelo, sem rosto pintado. Havia decidido trabalhar com os alunos o tema "Utopia". Segundo Fabiano, após a destruição ocorrida no mês passado, nada melhor do que uma tentativa de reconstrução, a partir de um conceito tão importante da filosofia. Neste dia, pude conversar rapidamente com Fabiano. Ele estava com pressa. Iria se atrasar para a aula. Carregava diário, cadernos e livros. Sua face estava triste e em certo momento senti uma certa animosidade por sua parte. Decidi não força e assim não the acompanhei naquela noite. Senti que naquele momento, não era bem-vindo. Temi pela continuidade 
desta pesquisa. Temi pela perda do contato. Temi. No caminho de volta para casa, tentei compreender o que estava ocorrendo. Foi em vão. Decidi então dar uma pausa na pesquisa, colocar as coisas no lugar e decidir por onde recomeçar.

\section{4/10/07 - E.E. Prof ${ }^{a}$ Ruth Cabral Troncarelli - COHAB II}

Quase um mês depois, quando minhas últimas esperanças de retomar a pesquisa já não existiam muito, Fabiano retomou o contato. Não quis entrar em detalhes sobre o que tinha ocorrido. Havia me ligado apenas para me convidar para a inauguração do circo utopia. "Circo Utopia", indaguei-Ihe, sem receber uma resposta clara do que tratava. Algum tempo depois, por meio de conversa com alunos e com o próprio Fabiano, descobri que tratava de um circo pedagógico que Fabiano havia montado no anfiteatro da escola e que, na última semana, as aulas de filosofia tinham sido realizadas lá. Nessas aulas, os alunos eram chamados a refletir sobre a utopia, por meio da arte e da figura do palhaço. Muitos alunos, inclusive, fantasiavam-se e iam desta maneira assistir aula.

Fabiano parecia novamente empolgado. Senti em sua fala que alguma coisa havia se alterado após o nosso último encontro. Talvez fosse a própria utopia que tivesse sendo reconstruída. Não sabia ao certo ainda. Não, podia, porém, perder esta oportunidade de continuar com a pesquisa. Depois de agradecer a alguns santos e santas, retomei as notas dos relatos anteriores e me pus a revisá-las, preparando-me para conhecer o circo utopia.

\section{5/10/07 - E.E. Prof Ruth Cabral Troncarelli - COHAB II}

Chove neste final de tarde de Primavera. A chegado horário de verão me permite chegar a COHAB ainda de dia. Posso, portanto, observar melhor sua paisagem. Vejo, numa pequena janela dos tantos apartamentos que preenchem a paisagem de um homogêneo cinza uma senhora que observa ao longe. Entre tantas grades, em meio a pequena abertura que resulta em uma janela, a pequena senhora observa. No que estará pensando... O que será que observa... Sinto uma intensa vontade de com ela conversar, entrevista-la, procurar entender o seu olhar. Mas continuo em direção a escola. Já são quase 19 horas. Logo a aula começará. 
Retomemos alguns fatos para compreendermos esta nova visita a COHAB. Durante esta semana, Fabiano organizou com os alunos um circo, ao qual denominaram Circo Utopia. O nome remonta ao tema de discussão que vem sendo desenvolvido com os alunos desde de setembro. Após debater com os alunos o capitalismo e suas consequências, durante quase todo o primeiro semestre e início de agosto, Fabiano sentiu a necessidade de pensar um outro mundo possível, uma alternativa a lógica econômica dominante. Era também, segundo Fabiano, um momento propício para criar a utopia da praça Celso Furtado, praça que é um projeto da Comunidade e que busca criar um espaço público de discussão e de produção crítica do conhecimento no lugar do vazio de significado deixado pela lógica de expansão capitalista. Como já foi dito, o projeto da praça Celso Furtado foi desenvolvido pelo Alma, grupo de Teatro Amador da Região, em parceria com a Escola Ruth Cabral Troncarelli e prevê a criação de um anfiteatro grego, um laboratório popular, além de áreas destinadas a educação ambiental e ao manejo sustentável do solo e da flora. Apesar de buscar o apoio da escola, apenas um professor do Ruth Cabral se interessou pelo projeto: Fabiano. Talvez isto se explique pelo fato de Fabiano ser morador da COHAB e a maioria dos outros professores fazerem parte de outras realidades. Ou Talvez pelo fato de que, diferente da Escola do Possível, outro projeto realizado na escola, o projeto da praça não tenha apoio institucional e, portanto, não resulta em pontos na carreira, nem em bolsas de auxílio.

O grande companheiro de Fabiano neste trabalho tem sido Aldo, um antigo morador da COHAB I que tem em sua história lutas políticas relacionadas a melhoria da qualidade de vida nos conjuntos habitacionais da região. Conheci Aldo há muito tempo, em um trabalho de campo realizado ainda quando estudante de geografia. Sua fala rápida e seu jeito explosivo me chamaram a atenção desde o início. Aldo é conhecido na região pela sua atuação na construção de praças. Não são, porém, praças vazias, repletas de cimento e concreto. São praças repletas de pássaros, atraídos que são pelas plantas frutíferas que ali ganham morada e que, em certa medida, vem dar vida ao cinza homogêneo da paisagem do lugar. Há algum tempo Aldo me levou para conhecer algumas de suas praças. Mostrou-me uma, localizada na COHAB I que tinha mais de dez anos. As árvores já estavam grandes, a quantidade de pássaros era impressionante, e a aquela pequena concentração de verde diante do cinza criava 
uma sensação de vida que ainda não havia encontrado na COHAB. A praça encontrava-se muito bem organizada e conservada. Surpreso com este fato, visto esta não ser a realidade das praças públicas da periferia de São Paulo, indagueiIhe sobre o que garantia aquela conservação.

\begin{abstract}
Ai é que está o segredo da coisa: fazer praça é fazer comunidade. Você começa mexendo aqui, ali, e daqui desce alguém do prédio da frente e diz que tem uma muda no apartamento e gostaria e ajudar na praça. Daqui a pouco, já tem um monte de muda e um monte de gente envolvida na praça. São essas pessoas que fazem a praça continuar. Quando a praça desaparecer será o sinal de que a comunidade já não existe mais.
\end{abstract}

A praça Celso Furtado, segundo próprio Aldo, é um projeto mais audacioso. Não será apenas uma praça, será um centro de produção do conhecimento na periferia.

Quero a moçada lendo Galileu, Newton. Quero que se perguntem quem foi Celso Furtado. Quero que as senhoras dos prédios revelem seus segredos de chá medicinais, que aprendam a cultivá-los. Tudo isso é fundamental para que a comunidade se forme aqui. Mas não qualquer comunidade, mas uma comunidade diferente, unida pelo conhecimento, pelo diálogo que produz conhecimento.

Fabiano havia abraçado aquele projeto e há algum tempo o discutia com os seus alunos. Ao escolher o tema utopia para ser desenvolvido nos meses de Setembro e Outubro, Fabiano via o momento propício para a construção coletiva da praça e do seu significado naquele determinado contexto. Para tanto, Fabiano passou a realizar uma série de intervenções teatrais naquele terreno baldio (futura praça, segundo Aldo), com a ajuda de alguns alunos e em outros lugares da região, com o intuito de fomentar entre os moradores locais a idéia da praça. Estas intervenções se transformaram em um filme que Fabiano apresentaria na escola. Dessa maneira, com esta série de ações, Fabiano trazia a tona aos alunos as possibilidades de realização do mundo que eles, enquanto pertencentes a um determinado local, tinham.

Ao adentrar a escola, já um pouco atrasado, sinto um certo estranhamento. Pela descrição que Fabiano havia me feito por telefone e por se tratar de um 
circo, esperava encontrar alegria e festa. Fabiano havia me dito que os alunos estavam empolgados com a idéia do circo. Desde segunda-feira chegavam mais cedo as aulas, fantasiavam-se e subiam para as aulas, vestidos com roupas diferentes e narizes de palhaço. A idéia era apenas chamar a atenção para o que estava ocorrendo, incomodar, conforme justifica Fabiano.

A escolha do palhaço enquanto metáfora estava relacionado a inquietação que este personagem traz ao momento atual de passividade e de perplexidade frente a tudo. Não se compunha de um ataque aos professores e alunos, mais uma indagação, um estranhamento.

Em outro texto, publicado em um manifesto realizado escrito por Fabiano e alguns de seus alunos o significado do palhaço, neste contexto, fica claro.

Que fique bem claro: o palhaço, no caso, sou eu!!! O palhaço como sátira do próprio circo. O professor errante como sátira da própria instituição escolar sedentária. 0 palhaço, personagem responsável pela insolência e irreverência, que é capaz de satirizar a todos e a tudo, especialmente as instituições. Como uma forma de fazer pensar e pensar com, junto a e ao lado de todo aquele disposto a desmascarar e fazer ver a verdade. Não pretendemos de modo algum chamar os professores de palhaços no sentido pejorativo mesmo porque nós, os integrantes da Cia somos os palhaços e não poderíamos tolerar o sentido pejorativo que jocosamente insistem em nos chamar. Temos um duplo desafio. Somos professores e palhaços.

Mas não foi assim que tudo foi compreendido.

Ao chegar na escola, percebo que o circo havia sido desmontado. Em seu lugar, senhores engravatados utilizavam o anfiteatro (antiga sede do circo) para oferecer cursos de computação com baixos preços e descontos aos alunos. Sem saber ainda o que estava ocorrendo, indago a um funcionário sobre Fabiano. Ele aponta para a sala de vídeo e para ela me dirijo. Encontro Fabiano que, na companhia de um aluno, assiste ao filme que produziu e sobre o qual já falei anteriormente. Fabiano parece desmotivado. Renan, o aluno que lhe faz companhia, também. Esta situação me deixa, durante alguns minutos, sem ação. 
Não sei por onde começar, o que dizer, o que perguntar. Sento-me, por um instante, e ponho-me a assistir ao filme. Após alguns minutos, Fabiano diminuiu o som da televisão e aos poucos vai me explicando o que estava ocorrendo. A relação com os outros professores se tornou insustentável. Novamente, os professores se sentiam ofendidos com as atividades realizadas por Fabiano que, segundo eles, desmoralizam a imagem do professor. A direção da escola, que durante muito tempo manteve uma atitude de conciliação cobrou explicações de Fabiano. O conselho de escola havia sido convocado. Tudo indicava um pedido formal de saída de Fabiano daquela unidade escolar. Fabiano decidiu, portanto, encerrar as atividades. O circo foi desmontado. No meio da situação, encontravam-se os alunos que buscavam compreender o que estava ocorrendo. "Mas o que fizemos de errado", questionava um aluno. "Devia ter colocado uma bomba no carro da diretora, assim como eu tinha planejado", desabafa um outro aluno. "O que os outros professores não sabem é que o trabalho que faço impede que uma bomba deixe de explodir no banheiro da escola a cada dia", desabafa Fabiano, apresentando no rosto uma sensação de cansaço de desânimo.

\section{Bate o sinal.}

Alguns alunos sobem para a aula. Apesar de toda a situação, Fabiano tem de continuar o seu trabalho, mas agora na sala de aula. Após a permissão de Fabiano, permaneço para acompanhar a aula que dará. Aos poucos, os alunos vão chegando. Reconheço os rostos de alguns e logo me apercebo de que se tratavam dos alunos que, há mais de um mês, havia acompanhado. Alguns alunos se dirigem para a televisão e mudam de canal. Passam a assistir a novela da Globo. O circo Utopia dá lugar ao circo da vida, ditado pelas regras da comunicação em massa.

Após os alunos se acomodarem na sala de vídeo (que na verdade é uma antiga cozinha adaptada, toda a verde, como o resto da escola), Fabiano explicaIhes um pouco sobre o vídeo e logo inicia sua reprodução. O filme traz uma série de imagens de violências, espalhadas no mundo todo. São imagens da guerra do Iraque, da fome na África, do desperdício e da miséria. A atenção dos alunos é total. A primeira cena é bastante forte. Em meio a uma região desértica no Iraque, um soldado, em cima de um tanque em movimento, mostra uma garrafa de água 
para crianças no chão que, desesperadamente, iniciam uma corrida incessante atrás do tanque, em busca da água. A cena choca por sua crueldade. Alguns alunos riem da situação. "Vou Ihe jogar no Saara e que ver você rir", ameaça um aluno, que atentamente, observa o filme.

Conforme as imagens vão passando, os alunos apresentam as mais diferentes reações. Uns parecem atentos ao que está acontecendo. Outros dormem. Mas há um aluno o qual observo mais atentamente. Descobri, posteriormente, que se chamava Fernando. Na primeira vez que o vi, lembro-me que foi um dos alunos que mais reclamou do que estava acontecendo, quando Fabiano pintara a cara e raspara o cabelo. Daquela vez, parecia entediado com aula. Desta vez, sua postura havia mudado. Estava atento no vídeo, não conseguia desgrudar os olhos um minuto das cenas que se sucediam. Parecia, em certa medida, se identificar com elas.

Fabiano interrompe o vídeo, sob protesto da maioria dos alunos. "Querem continuar a ver", pergunta aos alunos. "Coloca logo isso ai, professor", pedia um aluno um pouco entediado com a situação. "Por que será que adoramos ver a miséria, a violência, a destruição. Aqui está o progresso, a ciência, a razão", afirma Fabiano apontando para a imagem congelado do cogumelo atômico. Depois de um tempo de silêncio, Fernando pergunta: "mas o que o senhor quer nos façamos, sempre foi assim”. Fabiano permanece mudo por um tempo. Tento também compreender o peso da pergunta de Fernando. Aos pouco, Fabiano retoma a idéia de utopia que desenvolveram no mês e cita alguns filósofos que a embasam. Alguns murmúrios começam a aparecer. A aula vai perdendo um pouco do ritmo. Há pouca participação dos alunos. "Coloca o bope", grita um aluno do fundo da sala, em referência ao filme que relata a vida de um policial da tropa de elite da policia do Rio de Janeiro. No filme, cenas de tortura são tratadas como piadas e viraram piada popular, repetida aos montes em bares, escolas, universidade.

Fabiano fala da bomba atômica e de sua relação com a razão. "Nunca ouvi falar de bomba atômica" reclama um aluno. "O ser humano só pensa em si mesmo", afirma outro aluno. "Sempre vai ser assim" aponta outro aluno. Estas série de frases ditas pelos alunos me aponta para o fato de que pouca coisa havia mudado nos dois meses que separavam o primeiro dia de trabalho de campo e hoje. Havia nos alunos ainda um certo cansaço. Não atrapalhavam a aula, mas se 
negavam dela participar. Esperam ansiosos pelo bater do sinal, pela mudança de aula, pelo fim do confinamento na escola. Aguardavam ansiosos para deixar a escola que, em certa medida, pouco lhes fazia sentido.

Fernando, porém, escuta atentamente. Após a explicação de Fabiano, um novo silêncio advém, logo rompido por Fernando.

A gente gosta da violência na TV, porque acha que ela é tão cruel e que nunca vai acontecer com a gente. Mas ai que está o engano: a violência está aqui, acontece a todo o momento e a gente nem percebe.

Um novo silêncio. Rompido apenas pelo bater do sinal. Fernando é o último aluno a deixar a sala. Sem saber, registro a última fala de Fernando como aluno daquela escola. Algumas semanas depois, Fernando abandona os estudos. Sua pergunta continua no ar. Sua afirmação continua a incomodar.

Despeço-me de Fabiano, prometendo retornar após duas semanas com a transcrição dos textos e a finalização do trabalho.

Volto para casa, naquela noite, me lembrando do primeiro dia de trabalho de campo. Volto mudo, com a sensação de que alguma coisa, em minha percepção, havia se alterado. Não sabia ao certo ainda o que pensar, nem mesmo por onde começar a realização deste trabalho. Alguma coisa havia se alterado profundamente. Sentia-me mais próximo de uma realidade que antes se configurava tão distante. Mas, principalmente, sentia-me mais vivo e humano. $A$ inserção em um trabalho de campo etnográfico cria uma relação entre pesquisador e pesquisado que rompe as barreiras da chamada objetividade cientifica. É impossível se manter indiferente frente a uma realidade que busca compreender de tão perto. É difícil se manter imparcial, sem emitir juízos de valor, sem se preocupar com o que ira acontecer.

Ao voltar para casa, naquela noite, percebi o significado de tudo aquilo que havíamos discutido em sala de aula, na universidade e que durante algum tempo hesitei em compreender. Senti o significado das palavras de Geertz, Baitz, Malinowsky e de tantos outros tempo e pude começar a entender o que é o fazer etnográfico. Antes da teoria, era a práxis que ali se revelava.

Naquela noite, lembrei-me de Daiana e da conversa que há algum tempo tivemos. Hoje conseguia olhar a COHAB, o RUTH, seus professores e alunos de 
outra forma. Se Daiana estivesse aqui e pudesse me fazer uma pergunta talvez perguntaria: mas isso tudo já não estava aí?

Daiana talvez tenha razão: tudo já estava aqui, mas foram os olhos que mudaram.

\subsection{Retomando algumas idéias: da crise do trabalho docente a crise da sociedade do trabalho}

O relato que aqui apresentamos revela e nos ajuda a compreender um pouco mais elementos de determinadas práticas sócio-espaciais que tem no espaço social escola lócus de sua realização. Como pudemos perceber, o diálogo que se visa estabelecer entre a escola e o lugar, no caso da periferia, pode ganhar contornos conflituosos. Não se trata aqui de julgar. O que pudemos perceber nesta pesquisa é que, de determinada maneira, certos lugares, certas hierarquias sociais, já estão postas e definidas no interior da escola, sendo que romper com tais elementos pode se tornar tarefa bastante árdua. O que de fato, porém, a descrição por nós apresentada revela? De que forma ela pode ser interpretada?

De certa maneira, uma das questões que percorrem toda a descrição diz respeito à existência de um certo mal estar docente que se deixa revelar nas práticas já não mais significativas, no cansaço, na repetição burocrática. A reação dos professores em relação a ação desenvolvida por Fabiano diz respeito ao fato, em nossa perspectiva, de que, em certa medida, com tais ações, ele traz a tona, revela, escancara os principais elementos deste mal estar. Ao colocar em xeque 
uma certa autoridade que muitos professores já sabem que não possuem, mas que insistem em afirmar, Fabiano revela muitas das contradições que permeiam as práticas docentes na atualidade. Inclusive as suas.

Porém, há que se evitar, neste momento de nossa dissertação, uma visão maniqueísta da problemática analisada. Ou seja, não se pode pensar a ação de Fabiano como realização de um profeta que vem anunciar novos, denunciando os equívocos cometidos pelos outros professores, nem, ao mesmo tempo, condenar as práticas docentes ali existentes como portadoras de um discurso conservador e ligado a reprodução de uma certa hierarquia do poder. O desafio que este relato nos propõe diz respeito ao fato de como compreender este mal-estar docente sem cair em leituras simplistas e com um fim em si mesmo? Como relacioná-lo as condições materiais e imateriais encontradas por professores e alunos nas escolas das periferias paulistas e as próprias contradições presentes no desenvolvimento da sociedade atual? Em nossa perspectiva, a resposta para tais questões passa pela discussão acerca da categoria trabalho no interior do modo de produção capitalista.

A categoria trabalho, a partir de uma perspectiva da crítica social, se constitui enquanto uma das mais importantes para se compreender os processos sociais que perpassam a sociedade atual, totalizada pelo modo de produção capitalista. Desde Marx, a discussão da categoria trabalho no interior do modo de produção capitalista tem sido enfrentada não apenas como mera questão conceitual como tantas outras, mas como ponto fundamental na estruturação dos processos fundantes desta sociedade. $\mathrm{Na}$ atualidade, alguns autores - e entre eles destacamos a obra do crítico social Robert Kurz - têm retomado esta discussão acerca do trabalho, buscando desconstruir alguns mitos criados ao redor desta categoria. Para além de uma leitura superficial acerca do trabalho, que o analisa de forma positiva, porque ontológico e definidor da própria humanidade do homem - leitura esta que tem unido intelectuais de esquerda e de direita em uma perspectiva em relação ao trabalho - tais autores procuram elaborar uma discussão acerca do significado desta categoria no que diz respeito a sua condição histórica, ligada aos processos relacionados à modernidade. Segundo o próprio Kurz, esta sociedade surgida do desenvolvimento do modo de produção capitalista e do consequente advento da modernidade deve ser denominada de "Sociedade do Trabalho". Esta denominação se justifica no 
sentido em que o trabalho aparece, nesta sociedade, como mediador positivo das relações sociais, perpassando as práticas e os discursos científicos e ideológicos em diferentes momentos e situações.

\begin{abstract}
Em sua forma especificamente histórica, o trabalho nada mais é do que a exploração econômica abstrata, em empresas, da força de trabalho humana e das matériasprimas. Nesse sentido ele pertence exclusivamente à era moderna, e como tal foi acolhido acriticamente por ambos os sistemas conflitantes do pós-guerra. Esse trabalho, nessa curiosa forma abstrata, pode ser definido também como atividade que, de maneira igualmente curiosa, traz sua finalidade em si mesma. (KURZ, 1999:18)
\end{abstract}

Como podemos perceber neste trecho, o trabalho, segundo o autor, não é, de forma alguma, supra-histórico. Enquanto categoria explicativa da sociedade atual, ele surge como fundamento do modo de produção capitalista e da sociedade moderna dele advinda e só tem sentido enquanto categoria no interior desta sociedade. Não há, portanto, uma categoria trabalho atemporal, transistórica, ontologizada, como fundamento do homem e de sua formação enquanto ser social. Ao contrário, trata-se de um trabalho situado e localizado no interior destes processos, trabalho abstrato que tem como único objetivo reproduzir as contradições sociais ligadas ao modo de produção capitalista em sua totalização da sociedade.

Segundo Kurz, em outras formas de organizações sociais anteriores ao capitalismo - ou sistema mundial reprodutor de mercadorias como define o autor - a categoria trabalho não está presente. Contrapostas ao trabalho, categoria moderna como vimos, outras formas de atividades responsáveis pela mediação entre homem e meio, produziram outras maneiras objetivas e subjetivas de reproduzir a vida social, no que diz respeito às necessidades de sobrevivência biológica e social dos homens reunidos em comunidades. Com o advento do trabalho abstrato, a reprodução da sociedade está para além das necessidades reais da reprodução do homem enquanto ser biológico. O trabalho não representa o gasto de energia necessário para que os homens se reproduzam enquanto seres sociais e biológicos; é antes mediação necessária para que a lógica do sistema mundial produtor de mercadorias se realize. Apesar de sua aparência positiva, o trabalho abstrato, oculta a negatividade da alienação do homem em 
relação ao meio e as suas reais condições de reprodução social, em favor da reprodução de toda a sociedade que, neste caso, nada mais é do que a reprodução ampliada do sistema mundial produtor de mercadorias. Dessa maneira, a reprodução da sociedade do trabalho como elemento tautológico, com um fim em si mesmo, é o objetivo único que põe sobre a categoria trabalho a centralidade no interior do modo de produção capitalista, mesmo que a reprodução geral da sociedade apareça como reprodução isolada.

Ao analisar a crise do socialismo real, Robert Kurz aponta para o fato de que o mesmo deve ser entendido como um momento da reprodução ampliada do modo de produção capitalista e não como alternativa provável de enfrentamento, de revolução social contrária ao desenvolvimento do capitalismo. Para fundamentar seu argumento e sua crítica, o autor constrói uma análise que busca desvendar os pressupostos e fundamentos comuns existentes entre os dois sistemas econômicos e sociais, entre o socialismo real e o modo de produção capitalista. Entre os elementos comuns, o autor destaca a similaridade como os dos sistemas concebem a categoria trabalho, vista como positiva e ontológica. A exploração do trabalho enquanto fundamento destes dois sistemas e a crise verificada nos mesmos decorrentes das contradições relacionadas à sociedade do trabalho são, portanto, elementos que permitem uma análise para além da perspectiva dual do enfrentamento entre socialismo e capitalismo, possibilitando assim uma leitura que parta do pressuposto do socialismo real enquanto momento da reprodução ampliada do modo de produção capitalista.

A crítica da categoria trabalho, nesta perspectiva faz-se necessária no sentido em que muitas das análises feitas a partir da obra de Marx partem de uma certa idéia de ontologia do trabalho. Já no início final do século XIX Paul Lafargue apontava para aquilo que ele considerava como uma miopia do movimento proletariado, que seja, uma certa apologia do trabalho como redentor da humanidade. Segundo o autor,

Uma estranha loucura está a apossar-se das classes operárias das nações onde reina a civilização capitalista. Esta loucura arrasta atrase de si misérias individuais e sociais que, há dois séculos, atormentam a triste humanidade. Esta loucura consiste no amor ao trabalho, na paixão moribunda pelo trabalho, levada ao depauperamento das forças vitais do indivíduo e da sua prole. Em vez de 
reagirem contra esta aberração mental, os padres, os economistas e os moralistas sacrossantificam 0 trabalho." (LAFARGUE, 1977:11)

A ontologia do trabalho como elemento fundamental da humanidade pretende-se enquanto explicação racional capaz de dar sentido a chamada alienação do capital que se torna, por sua vez, alienação do trabalho. Segundo Lafargue, ao lutar a favor do trabalho e não contra a estrutura social na qual ele é um dos princípios fundamentais, os trabalhadores reproduzem as próprias condições de sua alienação, no sentido em que perdem de vista o fato de que esta sociedade reproduz-se criticamente a partir do trabalho abstrato. A afirmação do trabalho enquanto fundamento ontológico da humanidade, enquanto categorial atemporal oculta o fato de que só nesta organização social as relações sociais são totalizadas pelo trabalho. Neste sentido, o trabalho abstrato, desde o seu início, é anti-humano, porque limita as potencialidades dos homens àquelas definidas anteriormente pelo capital.

Em outra perspectiva, Hannah Arendt, em seu livro "A condição Humana" busca compreender os fundamentos da própria humanidade, mesmo que limitada as experiências dos atenienses no período clássico da Grécia Antiga. Em sua análise, o trabalho surge como um dos elementos - e não como o principal - na definição das relações dos homens entre si e com o meio. Para a autora, o trabalho humano seria o responsável pela sensação aparente de durabilidade frente a instabilidade da condição humana. Seria, portanto, a marca dos homens que, em certa medida, Ihes garantiria a permanência mesmo após a vida biológica ter se findado. Vale ressaltar que para a autora o trabalho não constitui em elemento central da vida humana, mas divide lugar com o labor e a ação enquanto elementos marcantes da condição humana. Enquanto o labor pode ser entendido como a energia vital necessária para que o homem reproduza sua condição de ser vivo, o trabalho e a ação seriam os elementos fundamentais para a realização do homem enquanto ser social. A partir do trabalho, o homem se relaciona com o meio e o transforma materialmente, criando uma certa aparência de durabilidade de sua condição instável. Já na ação é a partir da palavra, do discurso e de suas práticas políticas que esta sensação de durabilidade é construída. Neste sentido, para Arendt, a condição humana seria o resultado deste três elementos em relação que puderam ser claramente verificados na 
sociedade Ateniense.

Para a autora, porém, seria a ação elemento fundamental da afirmação do homem enquanto ser político. Segundo Arendt,

\begin{abstract}
É com palavras e atos que nos inserimos no mundo humano; e esta inserção é como um segundo nascimento, no qual confirmamos e assumimos o fato original e singular do nosso aparecimento físico original. Não nos é imposto pela necessidade, como o labor, nem se rege pela utilidade, como 0 trabalho. Pode ser estimulada, mas nunca condicionada pela presença dos outros em cuja companhia desejamos estar; seu ímpeto decorre do começo que vem ao mundo quando nascemos, e ao qual respondemos começando algo novo por nossa própria iniciativa. Agir, no sentido mais geral do termo, significa tomar iniciativa, iniciar (como indica a palavra grega archein, começar, ser o primeiro e, em alguns casos, governar), imprimir movimento a alguma coisa (que é o significado original do termo latino agere). (ARENDT, 2008: 189-190)
\end{abstract}

É, portanto, a partir da ação que o homem nasce para o mundo, constituise enquanto ser político, em relação constante com os outros homens e com o meio. Esta afirmação humana, como aponta Arendt, não se constituiu enquanto necessidade, mas é resultado da própria escolha, da sua capacidade de decidir e de iniciar algo novo.

Com o advento da modernidade, porém, há uma inversão destas relações entre labor, trabalho e ação que Arendt identifica como elemento central no processo de alienação humana. Segundo a autora, o trabalho que tinha como única utilidade criar a sensação de permanência da condição instável da humanidade se impõe como condição necessária para que o próprio trabalho abstrato, base do desenvolvimento do modo de produção capitalista, crie as condições para que uma nova forma de relação entre os homens e o meio surja. Para KURZ, é este trabalho que se torna a base da reprodução social da mercadoria. Para o autor,

A forma de reprodução social da mercadoria torna-se uma segunda natureza, cuja necessidade apresenta-se aos indivíduos igualmente insensível e exigente como o da primeira natureza, apesar de sua origem social. (KURZ, 1999:21) 
Neste sentido, numa tentativa de diálogo entre Arendt e Kurz o que vemos é que, como o advento do trabalho abstrato a partir do desenvolvimento do modo de produção capitalista, o labor, primeira natureza porque necessária a reprodução básica do homem enquanto ser biológico, só pode se realizar a partir da inserção do indivíduo nos termos da sociedade do trabalho, totalizada pelo trabalho abstrato. Apesar de surgir para o indivíduo como necessidade natural, este trabalho e as relações dele resultante é antes condição social de reprodução do modo de produção capitalista, sendo, portanto, necessário não a reprodução dos homens, mas a reprodução desta sociedade como um fim em si mesmo.

Totalizada, desta forma, pelo trabalho abstrato, a vida humana não pode ser realizar enquanto ação nos princípios definidos por Arendt. A ação, neste sentido, se realiza enquanto simulação, enquanto sensação de se agir consciente sem o saber que assim o faz em favor da própria reprodução do modo de produção capitalista. É, portanto, o caminho da desumanização no sentido em que o nascimento social dos homens já não mais se realiza.

A análise desta problemática aponta-nos, portanto, uma necessidade cada vez maior de se produzir uma crítica social e científica que tenha como objeto as categorias que dizem respeito ao modo de produção capitalista. De outra forma, se assim não procedermos, corremos o risco de produzir uma crítica que se constitui antes como apologia do modo de produção capitalista. Esta análise se torna ainda mais necessária quando a crise da chamada sociedade do trabalho se aprofunda, apontando assim seus limites e deixando escapar possibilidade de superação - não da crise, mas da sociedade e de seus fundamentos.

Voltemos agora para a realidade encontrada na E.E. Prof ${ }^{a}$ Ruth Cabral Troncarelli. Como uma forma de interpretação dos relatos obtidos em nossos trabalhos de campo naquela unidade escolar, propomos aqui pensar a crise do trabalho docente ali verificado enquanto momento da crise da sociedade do trabalho. A crise da sociedade do trabalho surge no momento inicial da sua formação. Põe e se repõem conforme aprofunda sua reprodução e assim suas contradições internas. Apesar de aparecer como solução da crise, a expansão do modo de produção capitalista aprofunda-a no sentido em que aprofunda também suas contradições fundamentais. No caso da análise da crise do trabalho docente enquanto momento da crise da sociedade do trabalho, algumas dificuldades são 
encontradas, principalmente no que diz respeito a se estabelecer uma relação entre um momento particular e o desenvolvimento geral da categoria trabalho no interior da sociedade do trabalho. A análise crítica do trabalho docente enquanto trabalho abstrato passa ao largo de diversas análises que propõem compreender a problemática dos professores em suas práticas cotidianas. O que temos visto é que muitas destas análises, ao centrar demais o olhar sobre a profissão docente enquanto trabalho diferente dos demais, isola o professor do restante da sociedade, como se a relação aluno-professor-escola pudesse ser pensada para além da análise de toda a sociedade. Nosso pressuposto teórico parte da seguinte afirmação: a crise do trabalho docente que ora verificamos é um momento da crise da sociedade do trabalho que apresenta suas particularidades e problemáticas próprias que precisam ser desvendadas para que a crise geral possa também ser melhor compreendida.

Para tanto, porém, faz-se necessário considerarmos que ao tratarmos da sociedade do trabalho o fazemos a partir de certa situação geográfica, que seja, um olhar situado na periferia dos processos ligados a lógica de reprodução do sistema mundial produtor de mercadorias. Falamos, portanto, de uma sociedade do trabalho que não se formou enquanto trabalho para todos, principalmente porque nossa acumulação primitiva não ocorreu nos moldes descritos por Marx. Ao mesmo tempo em que uma grande parcela da população no Brasil tem sido expropriada dos seus meios de produção, esta mesma parcela não se forma enquanto mão-de-obra assalariada, enquanto elemento vivo do trabalho abstrato. Vivemos, portanto, a perspectiva de uma sociedade do trabalho que se realiza enquanto sociedade do não-trabalho, o que contribui, em certa medida, para reafirmar a positividade do trabalho enquanto aparência. Nesta perspectiva, o problema não está no trabalho abstrato, mas em sua falta. $E$ as lutas sociais que em aparência e discurso se põem como críticas contribuem para a reprodução ampliada do modo de produção capitalista, ao defenderem o trabalho enquanto fundamento ontológico da humanidade.

Neste sentido, nossa análise parte da compreensão do trabalho docente dos professores em uma escola na periferia de São Paulo. Esta observação fazse necessária no sentido em que, na periferia, esta crise da sociedade do trabalho, que aqui parcialmente se formou, pode ser verificada mais claramente. $\mathrm{Na}$ periferia, encontramos a sociedade do trabalho ainda enquanto projeto, ao 
mesmo tempo em que já se põe como tragédia. E cabe a escola, pelo menos em discurso, realizar certas ações que permitam manter as aparências, ocultando a tragédia a partir da falsa produção do projeto. À escola, em grande medida, cabe realizar a continuidade da acumulação primitiva, formando ideologicamente a mão-de-obra a partir da apologia do trabalho enquanto único elemento redentor de toda a humanidade. Cabe, portanto, a escola, a partir da apologia do trabalho ocultar as contradições da sociedade do trabalho que se realize na atualidade enquanto negação do trabalho.

A partir disso, qual o papel que tem desempenhado o trabalho docente neste contexto? O discurso do trabalho docente tenta dar significado aquilo que, no interior do modo de produção capitalista não tem sentido para além do capital, que seja, o trabalho abstrato. Ao produzir, pelo menos em aparência, mão-de-obra para este trabalho, o faz sem que sejam desvendadas as contradições presentes no seu próprio interior e que são, enfim, contradições de toda a sociedade. Ao se esvaziar da crítica à sociedade do trabalho, o trabalho docente se reafirma enquanto trabalho abstrato, porque medido em horas-aulas, porque igual e quantificado em relação a qualquer outro trabalho. Isto talvez explique a utilização cada vez maior de termos econômicos e administrativos para avaliar o "desempenho" - e aqui está um deles - dos alunos e professores: produtividade, rendimento, etc.. A adoção da linguagem econômica e administrativa no interior do processo educativo é uma das marcas de uma sociedade dominada pelo trabalho abstrato. Para além da crítica, o que temos visto é a adequação a linguagem e aos lugares comuns que marcam esta sociedade e que ocultam suas contradições.

Da mesma forma, a adoção de currículos únicos, da centralização daquilo que deve ser ensinado, da negação do lugar como realidade a ser analisada, discutida, conhecida também são elementos que revelam a relação do trabalho docente com a manutenção das aparências em uma sociedade em crise. A aparente preocupação social de determinadas ações no sentido de centralização curricular que parecem significar anseios de toda a sociedade, ocultam os interesses únicos da sociedade do trabalho. A apologia do trabalho precisa se formar enquanto verdade transistórica e trans-espacial. Precisa ser verdade em São Paulo e em Recife. Precisa unir os trabalhadores em favor do trabalho e não 
contrários a eles. Para tanto, cabe também a escola realizar este discurso. Uma rápida olhada pelos livros didáticos espalhados pelo país e logo constataremos a força do discurso da sociedade do trabalho que rapidamente se espalha, criando assim a aparência de amalgama social em uma sociedade em ruptura.

Por sua vez, quando inerte e paralisante, o trabalho docente é também trabalho abstrato como outro qualquer, vazio de significados, repleto de contradições não desvendadas porque para isto não se propõe. Em certa medida, isso explica o cansaço, as faltas excessivas, o desânimo que temos encontrado nos corredores da EE Prof ${ }^{a}$ Ruth Cabral Troncarelli, cansaço diário de uma rotina que tem no pagamento do final do mês, muitas vezes, seu único significado. Nestes corredores também está presente certa nostalgia, uma romantização, a idealização de um passado que muitas vezes não existiu. Fala-se de melhores condições de trabalho, de perspectivas, de salários mais elevados, de um "momento onde o trabalho docente tinha significado". Não há, porém uma crítica à sociedade do trabalho, nem ao trabalho abstrato como seu fundamento. O que há, ao contrário, é uma reafirmação do mesmo quando ainda lhe era possível esconder parte de sua abstração porque a aparência de elevação social assim o permitia. Este ocultamento era possível também porque a acumulação de capital e sua reprodução "inseriam" os alunos recém-saídos destas salas de aula. À realização da acumulação primitiva, da formação da mão-de-obra assalariada acompanhava um processo de ascensão social pelo trabalho, isto porque, assim como o trabalho, a escola era também para poucos. Apenas alguns se formavam enquanto trabalho assalariado, enquanto uma massa gigantesca encontrava-se fora da escola, marginalmente a sociedade do trabalho. Havia perspectiva de futuro, mesmo que em aparência, mesmo que para alguns. Por causa disso, desta perspectiva de futuro, ainda era possível controlar a periferia. $O$ autocontrole estava presente como ação necessária, pelo menos em aparência, para a garantia de futuro.

Com o aprofundamento da crise da sociedade do trabalho, já não há mais esta perspectiva. A sociedade do trabalho, em sua crise mundial, se realiza enquanto negação do trabalho nas periferias. Gerações se reproduzem as margens desta sociedade e também no seu interior. A democratização do acesso a educação significou acesso ao discurso da sociedade do trabalho e a não 
inserção de fato na mesma enquanto trabalhador assalariado. Há agora excesso de trabalhadores formados em uma sociedade na qual o trabalho é cada vez menos necessário. Estas gerações, expropriadas da sociedade do trabalho porque nem mais constituídas enquanto reserva de mão-de-obra assalariada já não encontram sentindo no discurso do trabalho reproduzido no interior da escola. Encontram-se, ao mesmo tempo, entre uma certa contestação e o fatalismo, encontradas em frases como "mas sempre foi assim!". Como alunos, aprenderam a jogar a jogo, entenderam as regras da dissimulação presente na escola. Já pensam numa reprodução com o mínimo de trabalho, sem, porém, negar o capital e sua lógica. A expansão do tráfico de drogas e do domínio que exerce sobre a reprodução da vida social nas periferias é uma das marcas deste contexto.

E são todas estas contradições que explodem nos corredores da escola, que hoje se deixam aparecer e permeiam as relações sociais entre os diferentes sujeitos da educação. A violência, tantas vezes discutida e analisada, é um momento do aprofundamento da crise da sociedade do trabalho que tem negado a uma grande quantidade de pessoas a possibilidade de realização da própria vida, enquanto elemento biológico. Porém, a esta crise que ganha força na escola e ali se deixa transparecer não se tem acompanhado um processo de análise e interpretação crítica da mesma. Em vão, professores tentam se proteger. Em vão, muros são erguidos, vigias contratados, disciplina requerida. A crise social que ora verificamos não é crise da escola e nem daqueles que a compõem. É crise da sociedade do trabalho, crise que expõe os limites da reprodução desta sociedade e que encontra na periferia suas mais profundas marcas. Para além da revolução, a resposta dada nas periferias vem por meio da violência generalizada, do avanço do tráfico, da banalização da vida, da fetichização da técnica. O grito não é contra o capital como querem nos fazer crer algumas letras de RAP ${ }^{15}$, mas a favor da mercadoria, dos fetiches que sustentam a sua reprodução. É crise a favor da sociedade do trabalho, mesmo que esta já não seja mais possível. Crise que desvenda, por sua vez, a distância entre a crítica social e as práticas que por ora se realizam em pseudo-tentativas de enfrentamento.

O silêncio dos professores frente a tudo isso é marca de que a sociedade do trabalho nada deixa escapar. É a marca da ação transformada em simulação. Em nossa perspectiva, porém, a escola não pode ser pensada enquanto lugar do

\footnotetext{
15 Ritmo e poesia.
} 
trabalho. É, antes, lugar da ação, do nascimento social dos homens, como nos aponta Arendt. É pela, escola, que os alunos podem iniciar algo novo, inserir-se criticamente num mundo posto, que de forma, alguma são obrigados a aceitar. $E$ é esta a escolha que, em certa medida, deveria caber aos professores. Escolha que é antes ação. Ação que é nascimento político e social, reinvenção, mesmo que insuficiente, mas necessária, da ordem das relações entre os homens e a sociedade.

Para tanto, a questão não está em controlar ou não a crise, mas em interpretá-la a partir de uma análise mais ampla da relação com toda a sociedade do trabalho, em buscar no diálogo criativo com os diferentes sujeitos da educação caminhos para superação da sociedade do trabalho. Como docente, cabe decidir a forma de encará-la, buscando nos limites de minha própria prática, as possibilidades da crítica a ser construída. Para além de um discurso reprodutor das contradições relacionadas ao capital, faz-se necessário que se possibilite a um número cada vez maior de pessoas uma compreensão categorial da crise para que a aparência de solução não seja tomada por solução. A partir de práticas cotidianas, cabem aos docentes a construção de momentos, no interior do processo educativo, que permitam o desenvolvimento desta crítica categorial, desta análise que destitua a positividade do trabalho e abra outras possibilidades de enfrentamento da crise que não tomem as contradições como momentos da solução da crise. Só assim, talvez, a ação docente possa se destituir de seu caráter de trabalho, de abstração fundamental a reprodução desta sociedade.

Para além de um movimento de profissionalização docente, o que propomos é ação docente, pedagógica, crítica e criativa que, situada, relacione toda sociedade na compreensão de sua crise e das ações necessárias para sua superação. Ação pedagógica que rompa com a subordinação da crítica que vem da Universidade como discurso e que oculta o fato de que a crítica social ainda é campo para alguns. Só há sentido na crítica quando feita de forma a ampliar a ação e o diálogo, quando feita em conjunto, coletivamente e quando tem na perspectiva da crítica categorial seus fundamentos. Pensar a ação docente para além do trabalho docente é, portanto, pensar as possibilidades na construção desta crítica a partir da base, das periferias, da derrubadas dos muros da escola e da exposição da crise profunda da sociedade do trabalho na qual somos todos agentes-objetos. 
Talvez, em nossa perspectiva, o grande equívoco de Fabiano foi provocar demais os professores, criando um contexto e animosidade no qual o diálogo foi substituído pelo conflito, ao mesmo tempo em que reproduzia uma postura autoritária de não conversação. Os professores não podem ser encarados como inimigos como querem nos fazer crer os grandes burocratas da educação. Ao contrário, devem ser pensados como importantes sujeitos do processo de educação, capazes de criar as condições para que a crítica da sociedade atual se realize, bem como ações se desenvolvam no sentido de transformar tal sociedade. Ao estabelecer um campo de conflito entre os professores, Fabiano incorreu no erro de reduzir a problemática apenas do local, por mais que em suas ações buscasse ampliar o debate. Para além de uma crítica radical do modo de produção capitalista e sua materialização na periferia, a questão se tornou, na visão dos alunos, um diferença de posições particulares, personalistas, em uma disputa entre bem e mal que pouco faz sentido. As percepções dos alunos sobre todo o processo ocorrido na E.E. Prof ${ }^{a}$ Ruth Cabral Troncarelli serão analisadas no item

O que fica, portanto, desta experiência de campo é a compreensão de que a escola na periferia é também reveladora dos limites do desenvolvimento do modo de produção capitalista no sentido em que coloca em relação, em movimento, contradições fundamentais que ele mesmo produz. Unificados pela lógica do trabalho abstrato, trabalho em negação, professores e alunos, de formas diferenciadas buscam dialogar acerca de tais perspectivas, sendo que muitas vezes, a partir de leituras e práticas particulares demais, o diálogo não se constitui dando lugar ao conflito, ao enfrentamento. Faz-se necessário, portanto, que se desenvolva uma leitura mais ampla das problemáticas encontradas nas múltiplas escolas da periferia paulista para que as mesmas não sejam enfrentadas apenas como questões pontuais ou relacionadas a fase de desenvolvimento psicológico dos alunos. Para além destas perspectivas, é preciso compreender a relação inerente entre escola, lugar e poder, em uma análise que busque, nas interrelações entre escalas geográficas de realização do modo de produção capitalista os pontos de contatos existentes. 


\subsection{Quando os alunos descobrem a escola: entrevista com alunos da EE Profa. Ruth Cabral Troncarelli}

$\mathrm{Na}$ etapa final dos trabalhos de campos realizados na EE Profa. Ruth Cabral Troncarelli, realizamos uma entrevista com alguns alunos do Ensino Médio que haviam vivido e presenciado, de formas diferenciadas, todo o processo relatado anteriormente. $\mathrm{O}$ objetivo desta entrevista era compreender a percepção que os alunos tinham de tais processos e como os mesmos interferiam na relação que eles tinham com a escola. Para que pudéssemos obter uma gama interpretativa mais ampla, foram escolhidos alunos de séries diferentes. Alguns se conheciam há pouco tempo, outros ainda nem se falavam. Optei por uma entrevista coletiva com o intuito de que ela se tornasse também uma partilha de informações e para que os entrevistados se sentissem mais seguros e livres em relação ao que gostariam de falar. Por se tratar de adolescentes, percebi que havia certo receio acerca do uso que seria feita daquela entrevista. Vez por outra, no decorrer da entrevistas alguns dos entrevistados me indagavam, antes de afirmarem alguma coisa, se o que iriam dizer não poderia resultar em nenhum tipo de punição por parte de professores e direção. Com o andamento da entrevista, os alunos foram se sentindo mais seguros e passaram a falar mais livremente sobre suas percepções acerca da escola, dos professores, das relações de poder que ali se realizam.

Todos os entrevistados moram no Conjunto José Bonifácio há mais de quinze anos, sendo que a grande maioria nasceu e vive, até aquele momento da vida, no conjunto. São todos estudantes do período noturno da escola. A maioria trabalha durante o dia. Indagados sobre as dificuldades relacionadas ao fato de trabalharem e estudarem, um dos entrevistados afirmou que o principal motivo de ter sido reprovado no ano anterior estava diretamente relacionada ao cansaço decorrente do trabalho. A localização do emprego influencia diretamente neste cansaço. Trabalhar no centro da cidade, segundo um dos entrevistados, significa uma rotina de stress e cansaço que começa as 4 e meia da manhã e termina apenas às 23 horas. Dependendo do dia e das condições do trânsito, os atrasos são constantes. Muitas vezes, em favor do trabalho a escola é deixada em segundo plano.

Indagados sobre a repetição, os entrevistados apresentam opiniões 
divergentes sobre o assunto.

Eu acho super importante para o desempenho do aluno e a única coisa que é ruim é que a maioria dos alunos repetentes não se interessa. Você reprova ele um ano, entra na sala, igual na minha do ano passado tinha muito repetente, era praticamente impossível de você estudar. Você quer prestar atenção, o pessoal fica ali no fundo, naquela bagunça, falando alto, brincando com a professora, com a maior falta de respeito Não são todos. É importante para o desenvolvimento do aluno, mas também atrapalha um pouco porque eles não têm consciência de que os outros querem estudar.

Assim, eu acho na maioria das vezes é até boa, entre aspas, a maioria dos alunos que repete se continuar na mesma não melhora, só que assim no caso do André eu não acho certo porque tem um cara que vai, o professor escreve, que nem a gente tem um professor de matemática, eu acho ridículo a aula que ele dá. Ele chega, começa a escrever as coisas na lousa e pede para todo mundo copiar e ai depois ele passa uma atividade. Ele não explica, simplesmente ele passa na lousa. Para fazer a atividade, os alunos vai(sic) até ele, ai ele dá a resposta e depois passa visto no caderno. Você não aprende nada, ta ligado. $\mathrm{E}$ passa porque, que nem eu, eu me recuso a fazer este tipo de coisa, eu venho para a escola...

Nestas duas afirmações feitas durante a entrevista, os entrevistados expõem visões, ao mesmo tempo, divergentes e contraditórias. Ao mesmo tempo em que se afirma que a reprovação seria uma estratégia boa para aumentar o desenvolvimento dos alunos, toda a argumentação que se segue está na direção de questionar esta estratégia, apresentando mais as falhas e descréditos do que os pontos positivos deste processo. O que mais incomoda os alunos em relação à reprovação está no fato de que os critérios avaliados para se decidir pela aprovação ou reprovação de um aluno não estão claros. São, muitas vezes, subjetivos e dependem da relação que o aluno tem com o grupo de professores e com a direção da escola. Muitas vezes, o cumprimento de determinadas tarefas rotineiras, como cópias de textos da lousa no caderno, vistos no caderno, que pouca ou nada tem de significativo para o desenvolvimento do processo de aprendizagem dos alunos se torna o único critério para se decidir pela aprovação 
ou reprovação. Um dos entrevistados aponta para este fato.

Então, o motivo era falta de lição no caderno, eu prestava muita atenção, sabia o conteúdo, fazia provas e trabalhos, tirava notas boas, mas lição no caderno era o que era ruim pra mim.

Além disso, como aparece na fala de alguns dos entrevistados, a reprovação por si mesma não pode ser encarada como estratégia para obter um melhor desempenho do aluno. Muitos alunos, quando reprovados e submetidos à mesma estrutura de aula e de acompanhamento por parte da escola, perdem o interesse, desmotivam-se, sendo que alguns transformam esta perda de interesse em indisciplina. É constante na fala dos alunos a percepção de que os mesmo não encaram o processo de reprovação como algo justo, definido por regras claras, pré-determinadas e das quais todos tem conhecimento. Em nenhum momento da entrevista aparece na fala dos alunos alguma experiência vivida no ambiente escolar que denota a construção e discussão coletiva de critérios e objetivos relacionados ao processo de avaliação. O que surge, portanto, é o fato de que a maioria dos alunos passa por uma série de processos avaliativos sem saber ao certo quais os critérios e objetivos que direcionam os mesmos.

Segundo alguns entrevistados, esta falta de clareza na definição de critérios e objetivos no que concerne a avaliação e a outros momentos do processo de ensino-aprendizagem está relacionado também com a formação inicial dos professores do Ruth Cabral. Para os alunos, esta defasagem teórica em relação a formação inicial de muitos do professores resulta em aulas pouco significativas, marcadas mais pela cópia de textos na lousa e por chamadas orais no final do período, do que por momentos de diálogo e formação do pensamento crítico por meio de questionamentos que, partindo da realidade do aluno, ajude-os a compreender as questões que permeiam o mundo do qual fazem parte, ora como sujeitos, ora como objetos. Indagados sobre qual a postura esperada de um bom professor, os alunos apresentam alguns elementos interessantes que nos possibilitam compreender um pouco melhor a forma como os mesmo entendem a educação.

Vou dar o exemplo de uma professora que é bastante dinâmica. A gente teve aula com ela, Não ficava só passando lição na lousa, vira amiga dos alunos, por mais 
que a sala seja aquela bagunça, como você cria um relacionamento com o aluno, você consegue lidar melhor com a sala, quando você vai lá na frente e pega e fala "olha gente", to querendo dar aula, assim não dá, fica quieto, você não precisa bater no armário, bater na mesa, se o professor tivesse mais força de vontade, se tivesse aquela vontade mesma, "'não, vou dar aula porque eu gosto, porque eu quero ensinar" e ter este relacionamento com os alunos, com certeza fica mais fácil.

A "professora dinâmica", que surge na fala anterior, é aquela que se permite envolver com os alunos, que se deixa atravessar pelos problemas comuns que os incomoda que interfere no processo de ensino aprendizagem. É "a professora amiga", que substitui as agressões verbais e os atos de violência pela força da argumentação e pelo convencimento por intermédio do dialogo.

Em outra fala, um dos entrevistados apresenta a sua percepção do bom professor.

Acho que tem que ser mais simples do que toda esta situação. Tem que chegar na sala e fazer a proposta da aula. Ele tem que pegar e não massificar a sala, tratar toda a sala como se fosse um ser só. Tem aqueles alunos que dão um certo problema na aula dele, não permite dar aula nem como ele desejaria, acho que ele não tem que pegar e excluir estes alunos ou tratar de uma certa forma agressiva. Ta, o aluno não quer assistir a aula, ta causando algum problema, acho que deveria ver o porquê, pegar cada aluno especificamente e ver quais são os seus problemas, para saber realmente o que se passa, o porquê ele está fazendo isso, acho que ele não tem a intenção de estar atrapalhando a aula.

O respeito à individualidade e ao ritmo de desenvolvimento dos alunos surge, na fala anterior, como elemento fundamental que diferenciaria o bom e o mau professor. Caberia ao professor, segundo esta percepção, um olhar atento aos processos e situações que envolvem cada um dos alunos e que interferem no ritmo de aprendizagem dos mesmos. Ao invés de uma educação massificadora, que busca homogeneizar alunos, conteúdos e conhecimentos, a proposta de aula deveria ser clara em direção a respeitar a diversidade de situações e contextos que permeia cada um dos alunos. O bom professor seria, portanto, aquele que tivesse esta capacidade de reconhecer em cada um dos alunos um ser humano 
particular, repleto de problemas e questões a serem desvendadas.

É importante notar que a fala do entrevistado anterior vai ao encontro as críticas feitas por muitos educadores libertários, entre eles, Paulo Freire, a chamada educação massificadora, que pensa o processo de ensinoaprendizagem como um modelo a ser reproduzido em qualquer situação e lugar. A educação massificadora concebe o processo de ensino-aprendizagem mais como uma técnica do que um processo de reflexão-ação que resulta do diálogo e dos conflitos ocorridos entre os diferentes sujeitos que dele participam. Apesar de acertada, a crítica a educação massificadora, quando reduzida ao olhar apenas sobre a educação como teoria e quando cooptada por governos neoliberais que vêm nela possibilidades de redução de investimentos, acaba muitas vezes colocando a culpa de todo este processo no professor. Seria, portanto, o professor o único responsável por alterar esta função de reprodução de alienação que tem cumprindo a educação em caráter massificador.

Esta visão do professor como principal responsável pela alteração deste processo tem ganhado força nos últimos anos. A aplicação do modelo de gestão neoliberal da educação que tem como principal elemento a redução ampliada de gastos, tem aumentado as tarefas que compõem a série de atividades que passam a ser responsabilidades do professor. Cabe ao professor, portanto, a tarefa de contornar a ausência do Estado. É ele, o professor, que deve responder pelos problemas atuais da educação. Sem possibilidade de questionamentos aos órgãos públicos em relação a qualidade da educação, pais e alunos, vem nos professores os bodes expiatórios de todos os problemas que os afligem.

Em uma das falas dos entrevistados, há uma percepção muito clara acerca desta função política que o professor tem cumprido na educação atual.

Sinceramente, eu não culpo os professores, por causa que (sic) eles não tem um incentivo assim certo para trabalhar com este tipo de aluno, a remuneração, é muita coisa, é muita pressão, tipo, trabalhar em dois períodos, chegar e a sala não quer aprender, as vezes com o salário dele realmente não dá, assim tipo, os alunos do ensino médio, isso é um problema, os alunos que ficam falando a aula inteira, não é que o professor vai chegar e colocar ordem na sala, não é assim. Isso é um reflexo do que aconteceu desde o primário, que não teve esta educação certa, o que é certo, o que é errado, esta punição, assim quando você 
chega na fase adulta não tem como reverter isso. Você pode até ficar contra, mas o professor não tem culpa desta parte.

No trecho, o entrevistado aponta para o fato de que a responsabilidade pela falta de significado de muitas aulas não pode ser atribuída diretamente ao professor. Existe uma série de processos que vão desde a baixa remuneração dos docentes até a formação inicial dos alunos que são responsáveis pelas dificuldades enfrentadas no presente na sala de aula por alunos e professores. $\mathrm{O}$ que está explicito nesta fala são visões de uma mesma problemática que resultam em interpretações e ações diferenciadas. De um lado, o processo de hiperesponsabilização dos professores, que passam a ser os únicos responsáveis pelo desenvolvimento dos processos educativos, bem como pelo desempenho dos alunos. De outro lado, a hiporesponsabilizaçao dos docentes que busca também, numa leitura generalizante, motivos os mais diferentes para afirmar que as coisas assim estão e assim deverão continuar em decorrência da complexidade e a gama de ações necessárias para se alterar o problema. Em certa medida, na fala dos entrevistados, está em jogo e em discussão estas duas concepções de visão da problemática da educação que tem seus interesses ligados a outras esferas de poder e que chegam na escola de maneira direta, porém, diluída.

Uma das principais consequências desta discussão que aparece também na fala dos alunos diz respeito a visibilidade, positiva e negativa, que a figura do professor ganha nos debates acerca da educação. O professor se torna o elemento da linha de frente na "batalha da educação". A ele cabe a maioria das acusações que são feitas; a ele cabe a maioria das soluções que devem ser implementadas. Esta visibilidade da figura do professor poder ser interpretada também como uma estratégia de ocultação dos outros elementos responsáveis pelo processo de desestruturação da educação que tem por base, como vimos, a implementação de um modelo de gestão neoliberal da escola e de toda a esfera pública que tem sido implantado no Brasil nas últimas décadas. Para os alunos entrevistados, o professor torna-se, portanto, o alvo a ser atingido, o inimigo a ser derrotado, ao mesmo tempo em que é o salvador da pátria, o amigo para toda a hora. Há, neste sentido, uma relação contraditória que permeia as relações entre alunos e professores na EE Profa. Ruth Cabral Troncarelli e que aparece na fala dos entrevistados. 
Mas esse negócio de tratar o problema de cada aluno, lógico é legal isso, muito bonito. Ce (sic) trabalha pra caramba, imagine você ficar 11 horas por dia, sala que muda de $30 \mathrm{em}$ 30 alunos, e ter que tratar o problema de cada um assim, acho difícil para ele, acho que ele não tem nem uma estrutura emocional, uma estrutura toda para o professor fazer isso. Ninguém passa esta base para ele tratar assim. E fora que ele chega em casa e tem que corrigir matéria. Acho que é muito stress para ele ficar concentrando em cada problemazinho.

Outro importante elemento que apareceu durante a entrevista nas diferentes falas diz respeito ao fato de que muitos dos processos que ocorrem na escola são marcados pelo fingimento. Segundo uma das entrevistadas

Ta (sic), isso é chocante, mas quando você pede aula, o cara tudo bem eu vim disposto a dar aula, chega e passa um texto na lousa que não vai te servir para nada, só vai gastar tinta e papel. E isso não tem o que fazer, porque o cara finge que dá aula, se você ficar sentado você finge que ta (sic) sendo educado, se você vai na coordenação pedagógica ...

Aos poucos, na fala dos entrevistados, a escola vai surgindo como espaço social para além das aparências. Aquilo que aparece oculto para a maioria dos alunos vai se desvendando em cada novo depoimento, em cada nova fala dos alunos entrevistados. Surpreende-me o grau de consciência e de observação das relações que ocorrem na escola que os alunos entrevistados possuem. Descubro um pouco mais adiante que este conhecimento das relações ocultas que ocorrem na escola são decorrentes de atividades que os mesmos desenvolvem no interior da escola. Dois dos entrevistados são monitores da sala de informáticas. Outro entrevistado foi coordenador do grêmio estudantil durante um ano. A participação nestas atividades permitiu aos entrevistados conhecerem outros processos e elementos que fazem parte da realidade da escola enquanto espaço social e que ficam ocultos para a maioria dos alunos. Os conhecimentos destes elementos, por sua vez, cria uma visão mais crítica e embasada acerca da escola e das relações que a estruturam, bem como uma mudança de postura por parte dos alunos que 
passam a compreender melhor implicação política de suas ações como sujeitos que são do processo educativo e da escola enquanto espaço social.

Um dos fatos que melhor explicita esta descoberta da escola por parte dos alunos diz respeito a participação de alguns dos entrevistados nos HTPC Horário de Trabalho Pedagógico Coletivo e durantes os Conselhos de Classe e de Escola. Alicerçados na LDB de 1996 que garante a participação de um percentual de alunos nestas reuniões e apoiados por alguns professores, entre eles o professor Fabiano de Filosofia, os alunos passaram a fazer uso de seus direitos políticos de participarem destas reuniões e, dentro do possível, de opinarem sobre os rumos dos processos políticos e pedagógicos que envolvem a escola. $E$ foi partir da participação dos alunos nesta reunião que uma outra visão acerca da escola e dos seus diferentes sujeitos começou a ser construída. Uma visão que rompe com a idéia romântica da escola como lugar da harmonia e desprovida de conflito. São nestes momentos de reuniões, debates, discussões que o conflito se exacerba e que as posições políticas veem a tona, definindo e redefinindo os lugares e as funções sociais de cada sujeito.

Eu não imaginava isso. Olhava o professor assim a imagem da perfeição, estudar muito, ai eu comecei a ver assim, depois eu vi que não era nada disso.

Ah, depende, desde a sétima série eu já comecei a imaginar.

O que aconteceu, eu comecei a ver que não era assim, como a gente estava dentro da sala de informática a gente tinha um contato além com os professores. A gente já via como eles eram assim mesmo, tipo, na primeira oportunidade que eles tem, nossa aquele aluno, ele não tem dinheiro.

Ta (sic) no HTPC assim e ta (sic) falando o nome, ai a coordenadora pedagógica fala o nome, Amanda, quem é essa Amanda, a galinha, a bunduda, a que dá pra todos, é bem assim.

As frases acima revelam um pouco da percepção dos alunos sobre as relações dos sujeitos no interior da escola, bem como o quanto ainda predomina uma visão romantizada acerca dos professores enquanto elementos além do bem e do mal. Como vimos, a quebra desta visão romantizada é marcante para os 
alunos e aparece também em outros momentos da entrevista. Em outro fala, um dos entrevistados, cita o exemplo de sua participação no HTPC como membro do Grêmio estudantil. É interessante notar como o entrevistado aponta a sua desilusão, a quebra da imagem que tinha da escola e dos professores como elemento positivo para uma melhor compreensão da escola.

$\mathrm{E}$, realmente, aconteceu um choque, porque toda a imagem que eu tinha construído, ela desmoronou, isso foi muito proveitoso, foi uma boa experiência, mas em relação a isso é interessante, porque eu observo muito nos professores, observo que o maior problema da educação sejam aqueles que levam o nome de educadores, de mediadores, de tantos outros que tem por ai, porque eu ouvia o pessoal comentando aqui acerca do que ocorre no HTPC e no conselho de classe, nós podemos chamar isso de qualquer outra coisa, menos de pedagogia, especialmente porque, no conselho de classe, por exemplo, nós podemos fazer uma seleção de coisas horríveis, o aluno existem vários clichês, para diversos alunos, não se discute a pedagogia, a construção do saber, mas se discute na verdade se o aluno, é um aluno que tem um cheiro agradável, se é um aluno que tem talvez, uma família bem estruturada ou não, se é um aluno que sai com diversas alunas, enfim, discute-se tudo, menos o que é devido, e ai eu observei coisas horríveis, como vários apelidos que foram distribuídos, notas que foram adulteradas em cima da hora, por exemplo, um aluno tem lá três notas vermelhas em diversas matérias, ai eu estou observando aquilo, tomo isso como exemplo, filosofia, o aluno tem uma nota, por exemplo, $d$, os outros professores com os quais o aluno tem média e pergunta, como ele consegui esta nota, não pode ser assim, e ai o professor é pressionado a mudar a nota em cima da hora, a nota é mudada em cima da hora a pedido da própria coordenação.

Como podemos perceber, na fala dos professores os alunos descobrem os preconceitos que permeiam muitas das relações sociais ali estabelecidas. Como então falar de ética, de democracia, de direitos humanos, quando o não dito na escola revela preconceito, discriminação, falta de critérios? Como construir uma escola democrática se suas relações são marcadas pela dissimulação, pela atribuição de responsabilidades aos outros, pela falta e diálogo? Quando os alunos descobrem a escola, descobrem-se a si mesmos como elementos fundamentais das relações sociais que ali ocorrem e, portanto, como também responsáveis por ela. Ao perceberem estes novos elementos, dos quais não 
tinham conhecimento, os alunos passam a desvendar a escola de uma outra forma, analisando cada um dos elementos que a compõem como parte de um processo mais amplo que não se resume apenas na relação entre professor, aluno, sala de aula. Um exemplo pode ser visto pela análise que os alunos fizeram, durante a entrevista, da visita do Governador Geraldo Alckmin à escola. Provavelmente, sem o prévio conhecimento destas relações que aparecem ocultas na escola, a leitura desta visita seria outra, talvez menos ampla e mais restrita a lógica política do macro. Mas, com o conhecimento obtido, os alunos interpretaram as ações resultantes desta visita dentro de uma perspectiva que inclui estas relações ocultas que ocorrem na escola.

Um dia o governador veio aqui, a Agnes estava, o Geraldo Alckmin, o Paulo era monitor na época, os alunos ficaram trancados nas salas no intervalo, e cheio de gente bem vestida social assim, os alunos trancados na sala de aula, não foi Paulo, e os protestantes ali fora gritando.

o que não seria um aluno bom, seria aquele aluno que pressiona demais, o aluno que não cumpre com os seus deveres, entre aspas, quais seriam os deveres dos alunos: entrar na sala de aula quando bate o sinal, copiar devidamente a lição no seu caderno, resolver devidamente os exercícios propostos, e no final, ouvir o som do sinal novamente e se retirar em silencio, e este é o papel do aluno e todo aluno que não se encaixa neste perfil é tido como um péssimo aluno, mau aluno. E existe esta clara distinção e o que ocorreu no dia em que o governador veio aqui foi exatamente isso. Ocorreu uma reunião que eu presenciei, estou falando porque eu presenciei, em que a coordenação da escola se reuniu e disse o seguinte, quais são as salas que podem assistir o discurso de governador, em dez minutos foi decidido, tal, tal, tal, tal, e as outras o que a gente faz, tranca os portões e mantém elas lá dentro. Elas foram mantidas lá dentro e só foram chamadas as salas selecionadas para assistir o discurso do governador, foram colocadas atrás, enquanto na frente estavam os diretores de outras escolas, e outros cargos a mais. Então essa operação foi feita em quinze minutos, para receber o governador $e$ distribuíram bandeirinhas do estado de são Paulo, foi um show de ideologia, foi uma maravilha, e a gente viu de tudo ali, mas a grande verdade daquela situação toda era bem outra, a distinção entre os que prestam e os que não prestam. 
A presença do poder em sua forma estatal naquele dia no Ruth Cabral reestruturou as ordens e os lugares sociais dos sujeitos da educação. Era preciso normatizar o fingimento, definir quem devia e quem não devia estar presente. Para além de uma cobrança ou uma crítica ao poder, o que seria mais sensato vide a realidade do lugar, era fingir que tudo estava bem, que as coisas estavam no caminho certo. Normatizado o espetáculo, os que dele não puderam participar permaneceram trancafiados nas salas de aulas, a espera da liberdade que só viria quando o poder, em sua forma estatal, enfim retornasse ao seu lugar de origem. Ali, naquele momento, o significa sócio-espacial da escola começa a se desvendar.

Por que as portas e janelas não possuíam nenhum tipo de passagem que dessem para o lado de fora da escola ou para o pátio? Por que, entre os corredores das salas de aula e o pátio existiam enormes portas de ferro que naquele dia permaneceram fechadas? Tudo parecia enfim fazer sentido. A escola, naquilo que procurava ocultar, havia, num deslize qualquer, permitido se revelar. $\mathrm{E}$ foi o olhar atento destes alunos que possibilitou um outro entendimento acerca da escola e dos seus significados. Foi na lacuna deixada pela ausência-presença do Estado que a escola, em sua inserção no lugar, pode, enfim, ser revelada, em uma de suas faces que durante muito tempo ficou oculta.

A experiência descrita pelos alunos da visita do governador foi um dos momentos mais gratificantes de todos os trabalhos de campo que pude desenvolver no Ruth Cabral. Em certa medida, ao acompanhar o trabalho de Fabiano, pude perceber que o seu intuito era exatamente este, possibilitar aos alunos uma leitura crítica da escola enquanto instituição de uma determinada sociedade e enquanto espaço social inserido num determinado contexto e lugar. A relação do projeto da praça, da construção da esfera pública da COHAB partia de uma proposta de releitura crítica da sociedade atual e do urbanismo dela nascido, sendo que tal releitura partia da escola em direção a praça como possibilidade de reconstrução do lugar e das relações que o compõem. Para tanto, era necessário fazer uma interpretação crítica da escola enquanto instituição para que dela pudesse resultar a escola enquanto lugar da construção da esfera pública e da redefinição dos lugares. Esta releitura crítica aparece claramente no desvendamento que dois dos entrevistados fazem da escola enquanto espaço social. 
Eles não querem estas manifestações de individualidade. Só da uma olhada nesta sala. Grades nas janelas, as carteiras sempre uma atrás da outra, eu não vou olhar para ele, não posso olhar para ele do lado, ninguém olha para ninguém, o professor fica aqui na frente, ele fica de pé, fala para todo mundo, ele é o poderoso, o chefão, a imagem é maior, sabe, de princípio isso já causa um efeito

A gente se sente numa caixa. A gente ta aqui para aprender, você não pode se sentir livre e igual, você não é igual.

A estrutura da escola é devidamente pensada para a repressão. Toda a estrutura ideológica e física, é pensada para isso. O que nós acabamos de falar, da estrutura das janelas, dos corredores, que sempre mantém um fluxo e que não permite que haja, com que os alunos transitem com liberdade, não, a estrutura da escola é pensada para isso, a estrutura ideológica, também é pensada para isso.

O desvendamento dos significados da escola enquanto espaço social e de sua leitura a partir da inserção da mesma num determinado contexto e lugar foram os elementos fundamentais que guiaram o trabalho de Fabiano durante os seis meses que pude acompanhá-lo. Desconstruir para construir: este era o significado da utopia que Fabiano propunha discutir com os seus alunos. Mas antes de chegar a utopia, que não pode de forma alguma ser aqui lida como o não lugar, era preciso desconstruir as ideologias, as imposições que marcavam as interpretações da escola e que, de muitas formas, buscavam contrapor alunos e professores numa luta sem vencedores. Para além desta falsa luta, era preciso entender os significados mais amplos que a escola, inserida na COHAB possuía, bem como as possibilidades que nasciam desta inserção.

A construção da praça era, portanto, processo impar na construção de uma utopia. Porém, o processo se transformou no seu revés. Para além de um fortalecimento nas relações entre alunos e professores o que pudemos constatar fui o aumento dos conflitos, das divergências. A escola passou a se dividir entre os que apoiavam o projeto e os que viam nele excesso de trabalho sem retorno de nenhum tipo. Como era de se esperar, nesta disputa ingênua, os alunos também tomaram partido. Nas falas dos entrevistados, muitos procuram defender 
o professor Fabiano descaracterizando os outros professores.

O outro falando de não sei o que, ai o Fabiano chega, "a gente, que não sei o que, tenho um assunto muito importante, nossa teve um negócio de educação aqui, ele chegou assim aqui na escola, teve um negócio de educação muito da hora, que não sei o que, um boletim, saiu não sei o que, não sei o que, saiu uma proposta pedagógica de um cara muito louco", ai todo mundo fica olhando para a cara dele sem entender nada, e ele insistindo, sabe, insistindo, "vamo (sic) lá gente, vamo(sic) falar de pedagogia, vamo(sic) falar de educação", e não, a outra querendo falar do motel, gente querendo falar da menininha que pegou da outra sala, porque até professor pega menina da sala...

Apesar de um certo desvendamento das relações de poder na escola, os alunos ainda as identificam como meras relações pessoais, nas quais surgem diferentes sujeitos opostos, com interesses que são apenas seus e não respondem a relações mais amplas que dizem respeito a própria organização da sociedade e a situação da escola. Vale a pena ressaltar, porém, que esta perspectiva dos alunos, mesmo que de alguma forma distorcida, é momento necessário para o desenvolvimento de uma compreensão mais ampla dos processos que permeiam as relações entre escola, lugar e poder. Ao identificarem certos sujeitos e suas posições passam os alunos também a questionar as causas de tais sujeitos agirem daquela maneira. É a partir desta investigação que podem compreender que determinadas intencionalidades, por mais que apareçam como resultantes de escolhas autônomas dos sujeitos, só assim o são na aparência. De fato, tratam-se de escolhas apresentadas como únicas e naturais, sendo que seus sujeitos, se assim podemos chamá-los, acreditam se tratar de única opção, rotineira e aprovada pela maioria.

Neste processo de descoberta da escola na periferia, que se inicia na relação com o espaço urbano, no projeto da Praça, nas aulas de Fabiano e nas ações dos alunos é preciso romper com uma visão maniqueísta que procurar culpabilzar os homens por ações, que muitas vezes, estão além de suas escolhas. Da mesma forma, faz-se necessário fugir de interpretações que justificam ações como se nada além delas pudesse ser feito. Partir de uma perspectiva crítica que resulte em ações críticas significa atuar no limite entre o 
possível, o necessário e o suficiente, buscando resgatar o poder do diálogo e da construção coletiva e de perspectivas comuns. A culpabilização, por si só, ou enfrentamento como ocorreu na relação entre Fabiano e os outros professores pode resultar num processo de fragmentação da resistência, o que por ora verificamos no caso da EE Prof ${ }^{a}$ Ruth Cabral Troncarelli: o projeto encontra-se parado; há um clima intenso de mal estar entre Fabiano e o grupo de professores, bem como entre os alunos. Enquanto isso, a especulação imobiliária avança sobre os terrenos baldios e o mundo da mercadoria, mesmo como simulação, se afirma como projeto de vida para muitos dos moradores.

Em nossa perspectiva, um dos grandes equívocos de Fabiano foi não ter conseguido estabelecer um diálogo profícuo com os múltiplos sujeitos da educação que compõe a E.E. Prof ${ }^{a}$ Ruth Cabral Troncarelli. Por mais diferentes que sejam as perspectivas de tais sujeitos, o espaço público se constitui enquanto elemento de reconhecimento da diversidade e da individualidade daqueles que o compõem. Construir o espaço público, passa necessaraimante, por criar consenso através do diálogo, da argumentação e da ação política. Como nos aponta Arendt, o espaço público e ante o espaço da aparência nos quais homens e mulheres mostram o que são a partir do que falam e fazem. Resgatar e reafirmar alguns dos fóruns de discussão e debate (Conselho de Escola, APM, Grêmio) e abri-los, cada vez mais, para um número maior de participantes poderia ser uma das estratégias para o desenvolvimento do diálogo em busca da construção da escola enquanto espaço público.

Numa conversa informal, Fabiano revelou-me que um dos seus maiores medos era de que os alunos confundissem autonomia do pensamento com idolatria. O que pude verificar nos últimos dias em contato com os alunos é que muitas reproduziam em suas falas, perspectivas de Fabiano e já o reproduziam como se suas fossem. Para que tal atitude mudasse, Fabiano já pensava em novas ações para o próximo semestre. Infelizmente, não pude acompanhá-las. Mas ficou a sensação de que a continuidade do projeto poderia estar ali, na ação contínua de Fabiano, na sua compreensão de que todo e qualquer processo está repleto de contradições e é a partir delas que o próprio pensamento se constrói.

Concordo com Fabiano. Nestes meses, ao acompanhar de perto diferentes ações, desenvolvi as mais diferentes perspectivas acerca dos significados sócioespaciais da escola na periferia. $E$ foi exatamente por acompanhar tais 
contradições, levando-as até os seus limites que pude compreender que seus significados estão em plena construção e resultam das relações que seus diferentes sujeitos estabelecem com o lugar, o mundo e suas perspectivas, ora resistindo aos avanços do capital, ora com eles se articulando. E é desta articulação-resistência que a escola surge enquanto espaço revelador dos conflitos próprios de toda a sociedade que ali, no lugar, apresentam suas particularidades. 


\section{Considerações finais}

Durante todo o processo de produção desta pesquisa, evitamos realizar análises comparativas entre as duas escolas, objetos de nosso estudo. Isso se ocorreu com o intuito de se evitar generalizações que pudessem conotar certa superficialidade na pesquisa desenvolvida. Longe disso, nosso objetivo, em todos os capítulos até agora desenvolvidos, foi o de possibilitar um olhar atento sobre os elementos constituintes de cada uma das realidades estudadas, bem como das dinâmicas e processos particulares a eles relacionados. Para tanto, fizemos uso de uma linguagem descritiva e narrativa que permitisse ao leitor uma certa proximidade com os nossos objetos de estudos e a partir disso, produzisse análises e reflexões dos aspectos que pudesse colaborar para um melhor entendimento dos processos sócio-espaciais presentes nestes objetos.

Porém, gostaríamos de pedir licença ao leitor para que possamos realizar um exercício de comparação no presente capítulo. Correndo o risco, portanto, de sermos acusados daquilo que anteriormente apontamos, acreditamos ser necessária esta reflexão no sentido em que permite uma compreensão mais atenta das continuidades e descontinuidades existentes entre a mesma problemática, em diferentes formas, que ganha tom e cor, em cada um dos contextos estudados.

Como dissemos, nos capítulos iniciais desta pesquisa, nosso intuito era compreender a relação existente entre escola e lugar. Tal relação, porém, não comporta um único processo, muito menos, uma única abordagem. Ao contrário, trata-se de relação complexa, permeada por contradições e por implicações de todas as ordens que merece atenção e olhar atento do pesquisador. Não se pode correr o risco de uma leitura superficial que busca em um dos três elementos a base para que os outros dois se realizem. O lugar, nesta perspectiva, não pode ser pensado como pano de fundo para a escola, nem vice-e-versa. Estes elementos só existem em relação e é desta relação, dinâmica e contínua, que os mesmos se definem e redefinem, ganhando novos formatos, contextos, configurações.

Neste sentido, é preciso entender os elementos como entrecruzados numa 
dinâmica comum, permeados por interesses divergentes, definidos também que são pelos sujeitos que dão vida aos processos à eles relacionados. Feito este alerta, o que faremos aqui é um processo de autonomização parcial de um dos elementos que compõem a analise, conscientes, porém, de que, por si só, tal elemento não existe. O que pretendemos, contudo, é fornecer ao leitor um raciocínio mais didático e compreensível.

Como pudemos perceber, nas duas escolas analisadas, o poder, de diferentes formas, permeia e interfere nas relações sociais. Tais relações de poder têm, também no lugar, um dos seus lócus de realização. Mas ao mesmo tempo em que surge como base necessária para a realização do poder, o lugar apresenta as condições necessárias para o desvendamento e a superação da estrutura do mesmo. Em nossa perspectiva, estas possibilidades se delineiam no momento em que se une pesquisa e lugar. A pesquisa, feita a partir do lugar e tendo os lugares e suas múltiplas implicações como objeto, possibilita uma redefinição das relações sociais que ali ocorrem e que definem o poder, a escola e o lugar. $\mathrm{O}$ que nos incomodou, porém, durante toda a pesquisa é que, apesar de muitos professores e alunos terem esta noção da importância deste elemento na transformação da educação em direção a uma maior consciência crítica, na prática estas ações não se realizam. Em toda nossa pesquisa, fizemos a critica desta dicotomia entre teoria e prática, apresentando os principais elementos que consideramos serem fatores impeditivos para a realização desta transformação da educação e da pesquisa, a partir do lugar. Buscamos, ao descrever cada uma das realidades estudadas, analisar os principais processos particulares que mantém a relação entre lugar, escola e poder num patamar pouco alterável.

Porém, se há tantos elementos particulares, há também um elemento de ordem geral que, em nossa perspectiva, é fator fundamental para explicar o processo acima descrito. É na categoria lugar que encontramos este ponto de confluência e de comparação entre as duas realidades.

Existe, nos dois modelos de escola, uma lógica de reprodução do desenraizamento que tem como principal base a negação do lugar e das problemáticas que ele envolve. Nesta lógica, alunos e professores são levados a olhar para longe, a discutir realidades distantes, sem estabelecer ligações com o 
lugar do qual fazem parte e do qual são elementos constitutivos de processos e dinâmicas. Um dos mecanismos de reprodução deste desenraizamento está na afirmação cada vez mais forte que o discurso do mercado ganha nas duas escolas analisadas. Muitos são os professores a afirmar que a escola deve preparar para a vida. Mas de qual vida estamos falamos? Como falar de vida em um momento histórico e geográfico no qual a lógica do capital parece a tudo e a todos submeter, definindo os limites e as fronteiras que são os próprios limites e fronteiras do capital? A escola para a vida se torna, portanto, a escola para o mercado. E pior, para um mercado cada vez mais restrito, mas desumano e marcado pela exploração do homem pelo homem.

Nesta escola, o lugar surge como realidade a ser superada, como lugar a ser negado na busca de "um lugar ao sol". Permanecer no lugar significa estar atrás na lógica de competição capitalista. Não se poder perder tempo com o lugar, se existe um mundo de possibilidades e novidades que a lógica do capital, através do discurso do mercado propagado na escola, anuncia.

No caso da periferia, o lugar surge como a ausência do capital, lugar do nada, lugar a ser negado a todo e qualquer preço, mesmo que a sua negação esteja na diferenciação a partir do lugar. Reproduz-se a lógica de estar no lugar mesmo sem a ele pertencer. É preciso negar as contradições que o lugar apresenta porque, em certa medida, são elas reveladores das contradições que permeiam toda a reprodução ampliada do modo de produção capitalista.

Em entrevista ao jornal "O Estado de São Paulo", o economista Claudio de Moura Castro, ao comentar, de maneira bem simplista e superficial, os dados do SARESP ${ }^{16} 2007$ que apontam para o fato de que cerca de $80 \%$ dos alunos que concluem o Ensino Médio na Rede Estadual de São Paulo, não possuem conhecimentos básicos de matemática, faz a seguinte afirmação:

Vemos hoje uma situação genérica de escola de periferia que não são escolas, mas praças de guerra. Conflagradas. Não é política de educação, é de pacificação. Nas grandes cidades brasileiras, elas puxam as avaliações para baixo numa forma dramática.

Nesta afirmação, aparentemente óbvia, do autor, oculta-se uma leitura,

16 Sistema de Avaliação de Rendimento Escolar do Estado de São Paulo, criado em 1996 pela Secretaria Estadual de Educação. 
acerca da educação, enviesada e que reproduz o falso discurso do mérito. Que escolas são essas "que puxam as avaliações para baixo", como afirma o entrevistado? São maiorias ou minorias? Que funções tais escolas cumprem na trama de relações que definem e redefinem a periferia paulista, da qual fazem parte?

Enquanto escrevo este texto, vem a mente um episódio que pode contribuir para o aprofundamento das questões acima suscitadas. Lembro-me que, na primeira reunião de pais que participei como Professor Titular de Geografia da EMEF Dep. Flores da Cunha, no Parque Bancário, zona leste de São Paulo, percebi uma ausência gritante de pais. Apenas dois pais participaram da reunião. Porém, esta percepção não estava fora daquilo que se imagina e se escreve sobre a participação dos pais no acompanhamento da vida escolar dos alunos na periferia. Aquela ausência vinha apenas confirmar a série de idéias e teorias que perpassavam em minha mente,

Alguns dias depois, em um Sábado pela manhã, fui designado, juntamente com outros colegas professores, para fazer a distribuição de leite aos alunos. Esta distribuição faz parte de um programa da Prefeitura de São Paulo que ficou popularmente conhecido como "Leve Leite". Neste programa, cada criança recebe cinco latas de leite em pó por mês. Para retirar o leite, porém, as crianças precisam do acompanhamento de um adulto responsável. Foi então que me veio a surpresa: naquele sábado pela manhã, pude conhecer a quase totalidade dos pais dos alunos para os quais leciono. Pude, em conversas rápidas, saber um pouco mais de cada um dos alunos, seus problemas, bem como dialogar com os pais sobre algumas questões relacionadas a aprendizagem dos alunos. Aquilo que buscava alcançar durante a reunião de pais, pude realizar por meio da distribuição de leite.

Confesso que, de pronto, não me veio a tona a reflexão que por ora transformo em texto. Talvez, faltava-me ainda a indagação que agora faço, que seja, qual o significado da escola naquele lugar? Na periferia, a educação é questão secundária da escola. A escola, na periferia, é antes presença do Estado que, em quase tudo, está ausente. É a marca do Estado - e não qualquer tipo de Estado, mas do Estado patrimonialista, marcado pela confusão entre público e privado - que ali se faz perceber e pelo qual esperam pais, filhos, comunidade, que vão a direção da escola. 
Na periferia, a função primordial da escola é a de contenção social. A escola surge como proteção contra o lugar, visto por muitos como vazio e desprovido de sentido. No caso da COHAB José Bonifácio, este sentimento se acentua, principalmente naqueles que para ali foram sem serem consultados. $A$ escola já não é possibilidade de mudança de lugar. Há muito tempo perdeu este papel. O discurso do mercado não tem tanto força quando três ou quatros gerações de uma mesma família estão a margem dele. A escola apenas protege do lugar. Os muros são cada vez mais altos. Investe-se em grades, sistemas de segurança, mas mesmo assim, a biblioteca, recém-inaugurada, é assaltada. 0 lugar toma de assalto a escola, a invade; aos poucos derruba os muros que são erguidos exatamente para afastar os perigos que o lugar representa.

Num lugar marcado pelas contradições da expansão capitalista da cidade e do urbano, em sua forma crítica, a escola surge como materialização destas contradições, como apaziguamento e crise, como contenção e implosão social. Não é com o objetivo de alcançar educação formal que a maioria dos pais mandam seus filhos para a escola, mas o fazem para que se sintam seguros ao ter que deixarem os filhos quando forem trabalhar. Mas aqui é preciso fugir de visões maniqueístas dos problemas, buscando culpar os pais por esta ação. Antes, faz-se necessário compreender as seguintes questões: qual o significado da educação formal numa sociedade marcada pela crise do trabalho que encontra na periferia o seu lado mais crítico? Por que lutar por educação formal de qualidade para um possível futuro melhor, se a própria noção de futuro não existe? É preciso cobrar da escola ações no presente, que resolvam questões urgentes. É preciso afastar as crianças das drogas, do tráfico, da violência, enquanto os pais são obrigados a atravessar a cidade, em ônibus lotados para se reproduzirem enquanto trabalhadores subalternos, precários, reproduzindo assim as contradições inerentes ao modo de produção capitalista. Como pensar a educação sem existência de perspectiva? Como transplantar discursos e práticas realizadas em escolas localizadas em bairros de classe média para a periferia de São Paulo? Quem assim age se esquece de que, para além do discurso, a educação só acontece situada e contextualizada.

O que assusta os outros professores em Fabiano e Aldo é que eles convidam o lugar a participar da escola. Ao invés dos muros, escancaram os portões da escola, convidam os alunos a praça, visitam hospitais vestidos de 
palhaços. Em certa medida, Fabiano e Aldo rompem o limite entre a escola e o lugar. E pagam caro por isso. Mas ambos são é o lugar. Suas vidas estão ali. Fabiano não escolheu ao acaso lecionar naquela escola; foi antes ação política. Via em sua atuação na escola, a redefinição do seu lugar. Fabiano é morador da $\mathrm{COHAB}$ e, portanto, entende o lugar como aliado, como pertencente ao que é, o que pensa, e o que faz.

Mas Fabiano não pode esperar o mesmo dos outros professores: não estão ali pelo lugar, não pertencem e não querem fazer parte daquele lugar. Desenraizados que estão reproduzem a lógica de desenraizamento presente na escola. Não se trata de achar culpados. Falamos aqui de processos e de como os mesmo se realizam. Não se pode acusar os homens quando são também resultado do processo que reproduzem. A alienação do capital da qual são causa e consequência só poder se realizar com a alienação do lugar. É nos homens desenraizados, professores e alunos, que a alienação do lugar pode se reproduzir.

Por sua vez, em São Caetano do Sul, o discurso do lugar se torna a construção do não-lugar. Em São Caetano, os lugares estão postos. O nome, o sobrenome, a família, define o lugar ao qual cada um pertence. Não há possibilidades para além desta lógica, afirma o discurso. Não há lugar que fuja as definições dadas pelo discurso, feito exatamente por aqueles que querem manter os lugares privilegiados que o discurso ajuda a reproduzir. O lugar existe a partir do poder e se reproduz para que o poder, em uma certa estrutura, possa se reproduzir.

Na escola, o lugar surge como lugar de alguns. A cidade não é para todos, assim como não é para todos os direitos a ela relacionados. A escola ensina isso. Ensina no controle dos professores, na disciplina autoritária que mantém sobre os alunos, no ocultamento das relações políticas que permeiam os jogos de interesse em São Caetano do Sul. Ensina ao projetar num mercado promissor o futuro dos jovens que agradecidos, esquecem do lugar que nunca tiveram na cidade.

Enquanto os jovens de São Caetano, principalmente os mais abastados, se inserem cada vez mais na lógica do capital, a partir da submissão ao mercado e a fetichização da forma mercadoria, as relações de poder que criam a reprodução da desigualdade de acesso ao direito à cidade, podem se realizar sem nenhuma 
fiscalização. No subúrbio, os benefícios financeiros trazidos pelo capital ocultam toda e qualquer relação de poder. Por que se preocupar com corrupção, desvio de verba, privilégios de bairros em detrimento de outros se o discurso da cidade ainda me é suficiente, na medida em que, de uma maneira ou outra, estou nele inserido? Enquanto inseridos na lógica do capital naquilo que há de mais benéfico, que seja, sua retribuição financeira, o discurso da cidade basta para substituir a realidade.

E são estranhos os professores naquela cidade porque também a eles não é permitido se apropriar do lugar. Tudo é alterável, nada permanece. Dia após dia, o discurso e o poder invadem a vida dos professores, definindo passos, formas e modos de ser. Enraizar-se significa participar politicamente do discurso prédefinido e de todas as lógicas que ele pressupõe; significa abandonar o lugar para viver do discurso que reproduz desenraizamento em escala mundial.

Entre a periferia e o subúrbio, a lógica do desenraizamento se reproduz como elemento fundamental para a expansão do capital. Em cada lugar, em cada particularidade, é preciso reconhecer aquilo que existe de comum, que não se deixa escapar da lógica que a tudo quer totalizar, que busca nas falsas promessas de um mundo mais amplo, a negação do lugar. Demorei muito para compreender isso. Trazia ainda em meu pensamento esquemas de conhecimentos previamente definidos. Mas aos poucos fui compreendendo que a realidade não corresponde a representação que dela fazemos. E mais: que se torna tarefa árdua e fadada ao insucesso querer adequar a realidade aquilo que pensamos. Para fugir desta armadilha que, por vezes, a pesquisa acadêmica nos arma é preciso colocar os pés no chão, situar-nos, compreender que aquilo que fazemos e interpretamos é resultado da geografia que construímos.

Para se inverter esta lógica do desenraizamento presente entre o subúrbio e a periferia faz necessária a reconstrução da vida ativa, do significado da ação em contraposição a fabricação, o rompimento crítico pela palavra-discurso-ação que se faz em conjunto, no diálogo com o outro, na afirmação do espaço da aparência, utilizando-nos do conceito de Hannah Arendt. Para tanto, faz-se necessária uma nova política de espacialidade, como nos aponta MASSEY (2008). Esta política, por sua vez, requer um reconhecimento de um outro espaço, marcado pela subjetividade, pelo encontro de múltiplas trajetórias que se, num primeiro momento, são múltiplas apenas na aparência porque totalizadas pela 
lógica do capital, a partir do encontro, do diálogo criativo, da ação conjunta, se realizam enquanto múltiplas e unas.

Neste sentido, o espaço precisa ser pensado e realizado enquanto lócus da possibilidade, da abertura, do diálogo e do conflito. Uma nova política espacial requer uma outra espacialidade da política, uma outra configuração das relações sociais, uma redefinição dos homens não mais como mercadorias mas enquanto seres sociais nascidos a partir da ação. Pensar a escola nesta nova política da espacialidade passa, necessariamente, por pensar a construção do espaço público e a reconstrução do senso comum. Identificados os interesses predominantes hoje na escola e seus principais agentes, é preciso destituí-los como únicas trajetórias possíveis, assim como quer que pensemos os agentes da reprodução do capital. Por mais insuficiente que seja tal ação, é ela, por enquanto, possível e necessária. E, dessa forma, é ela que precisamos realizar se assumirmos de fato os compromissos que, enquanto seres humanos, nos propusemos.

Faz-se necessário também que rompamos com uma dicotomia míope que durante muito tempo tem confundido as análises em geografia, que seja, a dualidade local/global. Não se tratam de realidades distintas, dois pólos distantes ou coisa que o valha. Trata-se, sim, de uma forma de compreensão dos fenômenos que leva em consideração a multiplicidade de trajetórias dos mesmos. Toda ação é local e global porque portadora de intencionalidades e consequências que escapam a seus realizadores. Cabe-nos, a partir daí, desvendar tais intencionalidades e consequências para que possamos reduzir contradições mesmo sabendo ser isso tarefa difícil.

Que a escola possa se tornar um do lócus dessa nova política da espacialidade. Que assim como a história em Paulo Freire é o campo das possibilidades humanas, a Geografia também o possa ser. Que neste outro espaço, outros homens possam nascer, não como simulacros nem como resíduo, mas como afirmação da superação de um momento no qual, por quase 300 anos, os homens deixaram de existir e, em seus lugares, habitou um pleno vazio chamado mercadoria. Que assim o possa ser. 


\section{Posfácio}

\section{Para que Auschwitz não se repita: diálogo causal com Adorno}

Em 1965, numa conferencia proferida na rádio de Hessen, Adorno apresentou o que, em sua opinião, seria o grande desafio da Educação após a segunda guerra mundial. $\mathrm{O}$ autor inicia a sua fala com a seguinte afirmação: "a exigência que Auschwitz não se repita é a primeira de todas para a educação".

Tive acesso a este texto alguns meses antes de concluir esta dissertação e confesso que depois deste contato a afirmação de Adorno não me sai da cabeça. Qual o significado dessa exigência? Seríamos capazes de cumpri-la? Estaríamos dispostos a isso?

Questões e mais questões preencheram as linhas deste trabalho e por isso algumas respostas precisam ser dadas para que eu não corra o risco de ser acusado de superficial ou coisa que o valha. Para tanto, porém, faz-se necessário uma breve reflexão.

Qual o significado de Auschwitz na história da Humanidade? Auschwitz é a vitória do homem transformado em coisa, em máquina, em mercadoria. A vitória de um modelo, de uma concepção de mundo que projeta em necessidades para além dos homens a base de sua reprodução. $\mathrm{O}$ homem, em sua multiplicidade de formas e maneiras de habitar, de conviver, é posto de lado. Resta apenas a carcaça, o sangue esvaziado de vida, o peito oco preenchido do vazio repleto de mercadoria. Os corpos amontoados nos campos de concentração formando uma montanha homogênea de esqueléticos seres, os homens e mulheres transformados em cadáveres ambulantes, aguardando o momento para que aquela sobrevida mecânica fosse enfim interrompida, as valas e o cheiro podre que delas escapavam, nos deram a sensação do vazio e do nada tão bem descrita por Sartre e tantos outros autores. Os cogumelos atômicos de Hiroshima e Nagasaki vieram complementar a fase de transição para esta nova etapa da história humana que agora vivenciamos e que tem na totalização do capital e das relações por ele estabelecidas as formas de sua reprodução.

A experiência de Auschwitz arremessou os homens num mundo sem 
sentido e significados para além do mundo mercadoria, vendido, coisificado, no qual surgimos como seres inanimados que só tem importância se bem inseridos na lógica do capital. Auschwitz nos fez silenciar. Mudos, compramos e vendemos vidas transformadas em coisas, sonhos aprisionados, desejos manipulados, verdades inventadas e vendidas diariamente em cada novo produto, em cada nova mercadoria que promete por um fim a todo e qualquer sofrimento humano. Por muito tempo, ficamos calados tentando compreender tudo o que havia ocorrido. Bestificados, calamos frentes a tamanha bestialidade. Fizemos filmes, escrevemos livros, buscamos expiar de todas as formas possíveis as sensações que aquela experiência nos havia dado. Esquecemos porém de tentar compreende-la, perplexos que estávamos diante de sua existência.

Depois de algum tempo de silencio, quando recuperamos parte de nossa consciência, passamos a nos questionar: como tudo aquilo foi possível? Como pudemos permitir que aquilo ocorresse? E foi então que as primeiras respostas surgiram. A experiência de Auschwitz só foi possível porque se baseou numa estrutura de poder que tinha como principal elemento o monopólio do conhecimento científico. O monopólio construiu o poder e do poder se fez a ação. Não havia limite ético ou algo que pudesse impedir aquela experiência. Rompiase naquele momento o principio da ética como mediador das relações humanas e inaugurava-se o império da ética sob o capital. O homem se tornou cobaia do homem. O monopólio do conhecimento científico estruturou os lugares que cada um dos homens ocupariam naquela trágica experiência. Em busca do progresso, do avanço, de novos lucros, de novos mercados, o conhecimento científico, dominado por poucos, unido ao poder que este monopólio trazia, possibilitou a existência de Auschwitz. Os cientistas, os generais, os banqueiros, os industriais foram os grandes realizadores de Auschwitz e de toda a tragédia humana que dali surgiu.

Poderíamos aqui enumerar os avanços científicos obtidos durante as guerras. Mas isso pouco interessa. Muitos já tentaram justificar as atrocidades ocorridas em Auschwitz como mal necessário ao avanço da humanidade. Mas é preciso ir mais fundo e questionar a própria noção de progresso. Quem ganhou com Auschwtiz e Hiroshima? Quem controla os processos e os instrumentos que continuam a produzir morte em escala mundial? A quem interessa que 0 monopólio do conhecimento se mantenha e se reproduza? A estrutura de poder 
relacionada ao poder científico que é também poder mercadoria continua inalterável, porquanto que ainda desvendada.

E Auschwitz continua a se repetir: diariamente, em tantos lugares do mundo, nas favelas da Índia, China, Brasil; nos hospitais, escolas, presídios, novos campos de concentração, novos laboratórios que diariamente testam os limites dos homens transformados em coisas. Auschwitz não está no passado; mantém-se viva dentro de nós.

De certa maneira, esta pesquisa busca descrever os processos, em sua escala local de realização, que levam Auschwitz a se reproduzir diariamente, no biopoder que tem no corpo dos homens lugar de sua reprodução. Auschwitz se reproduz nas micro-relações de poder que se reproduzem nas relações dos diferentes sujeitos que, mesmo sem saber, reproduzem a lógica de sua alienação. Reproduz-se na concentração do poder na universidade, nas políticas públicas que pensam a educação de cima e que vêem em seus sujeitos massa a ser manipulada. Reproduz-se em nossas salas de aulas todas as vezes quando, como professores, alunos, pais, nos negamos a reconhecer a função que cumprimos na reprodução desta lógica de poder, quando aceitamos, calados, com aquele silêncio pós Auschwitz, que "as coisas são assim e que há pouco por se fazer". Toda vez que silenciamos, despertamos um pouco de Auschwitz, de Hiroshima, de Nagasaky, que carregamos dentro do peito.

Não se trata de uma denúncia vã ou de discurso jornalístico. É antes a prévia de uma ação, o nascimento implicado de uma nova implicação. Implicação que se dá diariamente nas salas de aulas das escolas públicas de São Paulo; na luta cotidiana, mesmo que limitada, para a reorganização e resignificação da ciência e do campo científico; na busca pela transformação da escola em lugar de produção de conhecimento, de diálogos, de partilhas, na afirmação de que a escola, enquanto espaço social, se faz na luta diária de seus diferentes sujeitos. Esta luta se dá também no questionamento cotidiano da Universidade e de sua apatia. Dá-se na valorização e no reconhecimento da vida que, apesar de tudo, de tanto violência e menosprezo, tende a resistir. Dá-se, portanto, em uma pesquisa que antes de tudo é vida porque implicada naquilo que penso, que faço e que sou.

É preciso escutar Adorno, fazer suas nossas palavras, para que Auschwitz não se repita. De outra forma, o silêncio que ainda nos persegue nos fará calar 
frente à barbárie imposta pela capital e seus diferentes agentes, que busca reduzir a experiência humana ao tempo cíclico da mercadoria.

Para encerrar, gostaria de contar outro episódio que marcou esta pesquisa e contribuiu para a construção da reflexão que aqui realizo.

Regiane tem 11 anos. Quer ser jogadora de futebol. É aluna da quinta série do Ensino Fundamental da EMEF Dep. Flores da Cunha. A primeira vez que falei com Regiane foi durante a correção de uma atividade relacionada a noção de lugar. Havia pedido que os alunos listassem todos os lugares pelos quais já haviam passado em sua vida e que escolhessem um que gostaram mais para escrever detalhadamente sobre ele. Regiane, uma menina magra, cabelo encaracolado, morena, rosto repleto de sardas, aparelhos nos dentes, veio até a minha mesa mostrar a lição. Havia listado em seu caderno uma série de nomes de lugares que já tinha visitado. Entre eles, constava o da cidade de Presidente Bernardes. Indaguei-a sobre o que tinha ido fazer na cidade. "Fui visitar o meu tio que está preso", respondeu, sem nenhum tipo de constrangimento. "Você gostou da cidade?”, continuei. “Gostei”. "Eu conheço aquela região. Já visitei Presidente Prudente", afirmei, tentado expandir a conversa. "Ah, professor, eu conheço aquela região toda. Já fui em tanto de presídio que nem me lembro mais", encerrou a menina, se dirigindo ao seu lugar, com o sorriso no rosto e nenhuma preocupação, deixando para trás um professor perplexo e desconstruído. Muitas de minhas teorias já não serviam mais. Mas deixava para trás também um professor feliz e me explico: em minhas idas e vindas do subúrbio a periferia, da periferia ao subúrbio, busquei construir com meus passos as marcas do lugar. $E$ apesar de tanta negação, da negatividade espalhada pela lógica do capital, vi surgir, nos homens e nos lugares, a própria implosão desta lógica, que brota da vida que, apesar de tudo, teima em resistir.

O sorriso de Regiane, acompanhado de sua simplicidade frente a vida, foi um dos momentos em que a negatividade do capital foi substituída pela vida em abundância. Não se trata de otimismo ou coisa que o valha; trata-se de reconhecer nos homens, apesar de tudo e ainda, as forças que vão para além do capital.

Que Auschwitz não se repita nos lugares em que pisamos para que o sonho humano, em suas mais diferentes faces, possa se realizar. Afinal, é este o sonho de Aldo, de Fabiano, de Thiago, de Regiane e de tantos outros que 
enxergam na flor que rompe o Asfalto o poema da vida descrito por Drummond:

“(...) Uma flor nasceu na rua!

Passem de longe, bonde, ônibus, rio de aço do tráfego.

Uma flora ainda desbotada

llude a polícia, rompe o asfalto.

Façam completo silêncio, paralisem os negócios,

Garanto que uma flor nasceu.

Sua cor não se percebe.

Suas pétalas não se abrem.

Seu nome não está nos livros.

É feia. Mas é realmente uma flor.

Sento-me no chão da capital do país às cinco horas da tarde

E lentamente passo a mão nessa forma insegura

Do lado das montanhas, nuvens maciças avolumam-se

Pequenos pontos brancos movem-se no mar, galinhas em pânico

É feia. Mas é uma flor. Furou o asfalto, o tédio, o nojo e o ódio"

(A Flor e a Náusea) 


\section{Bibliografia}

ADORNO, THEODOR. W. Educação e Emancipação. $4^{\circ}$ edição. São Paulo: Paz e Terra, 2006.

ALMEIDA, GUIDO DE. O Professor que não ensina. São Paulo: Summus, 1986.

ANDRADE, CARLOS DRUMMOND. Antologia Poética. $43^{\circ}$ edição. Rio de Janeiro: Record, 1999.

APPLE, M.; BEANE, J. (orgs.) Escolas Democráticas. $2^{\circ}$ edição. São Paulo: Cortez, 2001.

ARANTES, O.; VAINER, C.; MARICATO, E.; A cidade do Pensamento único. $3^{\circ}$ edição. Petrópolis: Vozes, 2002.

ARENDT, Hannah. O que é política? $2^{\circ}$ edição. Rio de Janeiro: Bertrand Brasil, 1999.

A condição humana. $9^{\circ}$ edição.São Paulo: Forense Universitária,1999.

Entre o passado e o Futuro. São Paulo: Perspectiva, 2000.

BAITZ, RICARDO. "A implicação: um novo sedimento a se explorar na Geografia?" IN Boletim Paulista de Geografia, n 84, julho de 2006. São Paulo: AGB.

BAUMAN, ZYGMUNT. Comunidade: a busca por segurança no mundo atual. Rio de Janeiro: Jorge Zahar, 2003.

. Em Busca da Política. Rio de Janeiro: Jorge Zahar, 2000.

. Vidas Desperdiçadas. Rio de Janeiro: Jorge Zahar, 2005. 
BOURDIEU, PIERRE. O poder simbólico. Rio de Janeiro: Bertrand Brasil, 2003. .Os usos sociais da ciência. São Paulo: UNESP, 2003.

CANETTI, ELIAS. Massa e poder. São Paulo: Cia das Letras, 2005.

CARLOS, ANA FANI ALESSANDRI. O lugar no do Mundo. São Paulo: Hucitec, 1996.

CAVALCANTI, LANA DE SOUZA. Geografia, escola e construção de conhecimentos. $3^{\circ}$ edição. Campinas: Papirus, 2001.

CERTEAU, MICHEL DE. A invenção do cotidiano: artes de fazer. Petrópolis: Vozes, 1994.

A invenção do cotidiano: morar, cozinhar. Petrópolis:

Vozes, 1997.

CHAUÍ, MARILENA. "Ideologia e educação" IN Educação e Sociedade, n 5 , janeiro, 1980.

- "Democratização e transparência: a tarefa do PT contra a despolitização e pela construção de uma ética pública" IN GUIMARÃES, J. Leituras da Crise. São Paulo, 2006.

Cultura e democracia. O discurso competente e outras falas. $1^{\circ}$ edição. São Paulo: Cortez, 2007.

DAMIANI, AMELIA LUISA. "O lugar e a produção do cotidiano" IN CARLOS, ANA F. A. Novos Caminhos da Geografia. São Paulo: Contexto, 2002.

A cidade (des) ordenada: concepção e cotidiano do conjunto habitacional Itaquera I. Tese de Doutorado. São Paulo: FFLCHUSP, 1993. "Urbanização Crítica e Situação Geográfica a partir da metrópole de São Paulo" IN CARLOS, A. F. A e OLIVEIRA, A. U. de (orgs.) Geografias de São Paulo: Representação e Crise da Metrópole. São Paulo: Contexto, 2004. 
DEMO, PEDRO. Pesquisa: princípio científico e educativo. $11^{a}$ edição. São Paulo: Cortez, 2005.

ELIAS, NOBERT. Os Estabelecidos e os Outsiders. São Paulo: Jorge Zahar, 2000.

FERES, CRISTINA L. P. Herdeiros da Fundação. Lavoro e famiglia em São Caetano. São Paulo: Hucitec, 2001.

FREIRE, P. Educação como prática da liberdade. $27^{\circ}$ edição. São Paulo: Paz e Terra, 2003.

FREIRE, P. e SHOR, I. Medo e Ousadia: cotidiano do professor. $2^{\circ}$ edição. São Paulo: Paz e Terra, 1987.

FOUCAULT, MICHEL. Microfísica do poder. 19ª edição. São Paulo: Graal, 2004. Em defesa da Sociedade. São Paulo: Martins Fontes, 2005.

GADOTTI, MOACIR. Concepção Dialética de Educação. Um estudo introdutório. São Paulo: Cortez, 1983. et all. Pedagogia: diálogo e conflito. $2^{\circ}$ edição. São Paulo: Cortez, 1986. . Escola Cidadã: Educação para e pela cidadania. São Paulo: IPF. Acessado em 15/01/2007.

GARCIA, CARLA CRISTINA. As outras vozes. Memórias femininas em São Caetano do Sul. São Paulo: Hucitec, 1998.

GEERTZ, Clifford. A Interpretação das Culturas. Rio de Janeiro: LTC, 1989.

GRAMSCI, ANTONIO. Concepção dialética da história. $4^{\circ}$ edição. Rio de Janeiro: Civilização Brasileira, 1981. 
HELLER, AGNES. Sociología de la vida cotidiana. $4^{\circ}$ edição. Barcelona: Ediciones Peninsula, 1994. . O cotidiano e a História. São Paulo: Paz e Terra,1988.

HERNANDEZ, FERNANDO. Transgressão e mudança na educação. Os projetos de trabalho. São Paulo: Artmed, 1998.

JULIA, DOMINIQUE. "A cultura escolar como objeto histórico" IN Revista Brasileira de História da Educação, Campinas, n.1, 2001.

JUNIOR, ENIO MORO. A percepção visual de um urbano em Transição: o caso de São Caetano do Sul. Dissertação de Mestrado. São Paulo: FAU-USP, 1998.

KOWARICK, Lúcio. A Espoliação Urbana. São Paulo: Paz e Terra, 1980.

KURZ, ROBERT. O Colapso da Modernização. $5^{\circ}$ edição. São Paulo: Paz e Terra, 1999.

LAFARGUE, PAUL. O direito à preguiça. Lisboa: Teorema, 1977.

LEFEBVRE, H. O Direito à Cidade. $3^{\circ}$ edição. São Paulo: Centauro, 2004.

LEVI-STRAUSS, CLAUDE. Tristes trópicos. São Paulo: Cia das Letras. 2005.

LODUCA, WILSON. São Caetano: de várzeas alagadiças a príncipe dos municípios. São Caetano do Sul: Fundação Pró-memória, 1999.

LYOTARD, JEAN-FRANÇOIS. A condição pós-moderna. $7^{\circ}$ edição. São Paulo: José Olimpio, 2002.

MARTINS, José de Souza. O Imaginário na Imigração Italiana. São Caetano do Sul: Fundação Pró-memória, 2003. 
Diário de Fim de século. Notas sobre o núcleo colonial de São Caetano no século XIX. São Caetano do Sul: Fundação Prómemória, 1998.

. Subúrbio. Vida Cotidiana e história no subúrbio da cidade de São Paulo: São Caetano, do fim do Império ao fim da República Velha. São Paulo: Hucitec, 1992.

MATTOS, MEIRA. Brasil, Geopolítica e Destino. Rio de Janeiro: Biblioteca do Exército, 1975.

MCCOURT, FRANK. Ei, professor. Rio de Janeiro: Intrínseca, 2006

MEDICI, ADEMIR. Migração e Urbanização. A presença de São Caetano na região do ABC. São Paulo: Hucitec, 1993.

MOREIRA, RUY. Para onde vai o pensamento geográfico? Por uma epistemologia crítica. São Paulo: Contexto, 2006.

. O discurso do Avesso (para a crítica da Geografia que se ensina). Rio de Janeiro: Dois Pontos, 1987.

NAKANO, A. K. 4 COHABS da Zona Leste de São Paulo: território, poder e segregação. Dissertação de Mestrado. São Paulo: FAUUSP, 2002.

RAMOS, A. M. C e SOUZA, M. de. Cotidiano e História em São Caetano do Sul. São Paulo: Hucitec, 1992.

RODRIGUES, MÁRIO PORFÍRIO. Um Jornal, uma vida. A saga do jornal de São Caetano e outras mais. São Caetano do Sul: Fundação Pró-Memória, 2005.

ROMÃO, JOSÉ EUSTÁQUIO. Dialética da diferença. 0 projeto da escola cidadã frente ao projeto pedagógico neoliberal. São Paulo: Cortez, 2000.

SANTOS, MILTON. A Natureza do Espaço. São Paulo: Edusp, 2003. . O espaço do cidadão. $2^{\circ}$ edição. São Paulo: Nobel, 1992. 
SMITH, NEIL. Desenvolvimento Desigual: natureza, capital e produção do espaço. Rio de Janeiro: Bertrand Brasil, 1988.

VASCONCELLOS, CELSO DOS S. Planejamento. Projeto de Ensino Aprendizagem e Projeto Político-Pedagógico. $17^{\circ}$ edição. São Paulo: Libertad, 2007.

WEBER, Marx. Ciência e Política: duas vocações. São Paulo: Cultrix, 2007. 


\section{Anexos}

\section{Entrevista Integral com alunos da EE Prof ${ }^{\mathrm{a}}$ Ruth Cabral Troncarelli}

Alan - Sou Alan, tenho dezesseis anos, moro na COHAB há dezesseis anos, estudo aqui no Ruth desde a minha sexta série, atualmente estou no segundo ano.

Arthur - Meu nome é Arthur, eu tenho dezessete anos, moro aqui na COHAB desde que eu nasci, estudo aqui no Ruth faz uns dois anos mais ou menos. Eu odeio a diretora e eu sou punk.

Juscilene - Meu nome é Juscilene, tenho dezesseis anos moro aqui em Itaquera há dezesseis anos, não na COHAB, mas em alguns lugares. Estudo aqui no Ruth Cabral desde da quinta série e estou cursando o segundo ano do Ensino Médio.

André - Meu nome é André, eu tenho dezessete anos, comecei a estudar no Ruth este ano, não sei quanto tempo eu moro em Itaquera, mas eu moro aqui perto, aqui na COHAB mesmo.

Arthur - Você não sabe quanto tempo você mora aqui

André - É que eu fui para o Parque São Lucas e voltei, entendeu. Fui para o São Lucas e do São Lucas para cá.

Agnes - Meu nome é Agnes, eu tenho dezessete anos, eu moro aqui em Itaquera desde, desde sempre, sempre morei aqui, estou no segundo ano do Ensino Médio e estudo aqui desde a quinta série.

Arthur - Só para concluir, eu repeti ano passado.

André - Eu também.

Eduardo - Vocês repetiram o ano passado, qual que foi o motivo?

André - Então, o motivo era falta de lição no caderno, eu prestava muita atenção, sabia o conteúdo, fazia provas e trabalhos, tirava notas boas, mas lição no caderno era o que era ruim pra mim.

Arthur - E eu repeti porque estava num serviço escravo, e ficava muito cansado para vir para a escola e repeti por causa de falta.

Eduardo - Todos vocês trabalham?

Juscilene - Eu trabalho

Eduardo - Aqui próximo

Juscilene - Eu trabalho na Penha 
André - Eu fiz uma entrevista hoje e vou começar amanhã

Eduardo - Você não tinha sido reprovado na entrevista?

André - Era só brincadeira, só para ver a reação dele.

Arthur - Ele acha que eu sou cobaia

André - la ser bem engraçado, ele tinha falado para mim: se você não passar não vem mais pra escola, pelo amor de Deus.

Eduardo - Vocês disseram que reprovaram, é muito costumeiro as pessoas reprovarem aqui no Ruth?

André - Não foi aqui no Ruth, foi no São Lucas, no Joaquim Silvério.

Arthur - Mas pelo que eu vi aqui no Ruth é bastante comum

Alan - Na minha sala, quanto alunos não é repetente? Muitos.

Agnes - Mas isso começou agora porque antes você podia fazer o que você quisesse que você não era reprovado. Começou desde o ano passado, desde o ano retrasado, que eles começaram a repetir, antes eles não repetiam.

Juscilene - Não qualquer coisa, porque no primeiro ano, tinha um rapaz lá de dezoito anos e outro de 23 anos e eles já tinham repetido um pouquinho já. $E$ tem uns casos que eles passavam, não eram todos.

Agnes - Então, porque que eles começaram a repetir agora? Porque o noturno ia acabar, não ia ter mais aula aqui no noturno porque não tinha mais gente para estudar, a maior parte das pessoas estava de manha. E ai tinha isso, no noturno todo mundo fazia o que queria e não era reprovado. $E$ foi no ano passado que mudou completamente isso.

Eduardo - E foi a direção que mudou?

Agnes - Foi

Eduardo - E o que vocês acham da reprovação?

André - Bom

Juscilene - Eu acho super importante para o desempenho do aluno e a única coisa que é ruim é que a maioria dos alunos repetentes não se interessa. Você reprova ele um ano, entra na sala, igual na minha do ano passado tinha muito repetente, era praticamente impossível de você estudar. Você quer prestar atenção, o pessoal fica ali no fundo, naquela bagunça, falando alto, brincando com a professora, com a maior falta de respeito Não são todos. É importante para o desenvolvimento do aluno, mas também atrapalha um pouco porque eles não 
têm consciência de que os outros querem estudar.

Arthur - Assim, eu acho na maioria das vezes é até boa, entre aspas, a maioria dos alunos que repete se continuar na mesma não melhora, só que assim no caso do André eu não acho certo porque tem um cara que vai, o professor escreve, que nem a gente tem um professor de matemática, eu acho ridículo a aula que ele dá. Ele chega, começa a escrever as coisas na lousa e pede para todo mundo copiar e ai depois ele passa uma atividade. Ele não explica, simplesmente ele passa na lousa. Para fazer a atividade, os alunos vai até ele, ai ele dá a resposta e depois passa visto no caderno. Você não aprende nada, ta ligado. E passa porque, que nem eu, eu me recuso a fazer este tipo de coisa, eu venho para a escola...

André - Em outras palavras é quem tem no caderno passa

Arthur - É e eu acho ridículo, eu acho que a gente está aqui na escola para aprender, independente de que forma seja, se eu conseguir entender a matéria isso é que é importante, não se eu sou uma máquina de copiar.

Eduardo - Pensando ai no caso deste professor, pensando no geral, nos professores do Ruth, que vocês teriam a dizer sobre esta questão sobre a forma como eles dão aula, como eles preparam a aula?

Arthur - Sinceramente, eu não culpo os professores, por causa que eles não tem um incentivo assim certo para trabalhar com este tipo de aluno, a remuneração, é muita coisa, é muita pressão, tipo, trabalhar em dois períodos, chegar e a sala não quer aprender, as vezes com o salário dele realmente não dá, assim tipo, os alunos do ensino médio, isso é um problema, os alunos que ficam falando a aula inteira, não é que o professor vai chegar e colocar ordem na sala, não é assim. Isso é um reflexo do que aconteceu desde o primário, que não teve esta educação certa, o que é certo, o que é errado, esta punição, assim quando você chega na fase adulta não tem como reverter isso. Você pode até ficar contra, mas o professor não tem culpa desta parte.

Agnes - Eu concordo com o que o Arthur está falando, mas também tem que pensar em outra coisa, tem professores que tem a mesma formação e mesmo assim eles buscam, eles vão atrás, tentar pelo menos fazer alguma coisa. Claro que não é muitas vezes bem sucedida, mas eles tentam.

Arthur - Mas isso depende da auto-estima do cara. Por exemplo, o cara nasce para ser professor: ai o cara vai atrás, se esforça.

Juscilene - Depende também dos alunos. Vou dar o exemplo de uma professora que é bastante dinâmica. A gente teve aula com ela, Não ficava só passando lição na lousa, vira amiga dos alunos, por mais que a sala seja aquela bagunça, como você cria um relacionamento com o aluno, você consegue lidar melhor com a sala, quando você vai lá na frente e pega e fala "olha gente", to querendo dar aula, assim não dá, fica quieto, você não precisa bater no armário, bater na mesa, se o professor tivesse mais força de vontade, se tivesse aquela vontade mesma, "'não, vou dar aula porque eu gosto, porque eu quero ensinar" e ter este 
relacionamento com os alunos, com certeza fica mais fácil.

Agnes - Então, isto também é importante, tem até professores que tem isso, mas o problema é a formação. Tem até isso, esta maneira de lidar com os alunos e tal, só que na parte de conteúdo mesmo, da matéria, das coisas que eles sabem, às vezes fica muito a desejar.

Eduardo - Vocês acham que um bom professor tem que ter que características?

Agnes - Saber do que está falando

Alan - Tem que saber lidar com o aluno, tem que saber respeitar para receber o respeito, e com certeza, se a gente for observar, o segredo desta professora e de outros professores que a gente conhece é este, eles respeitam o aluno. Respeita o aluno e recebe o respeito do aluno.

Eduardo - Respeitar o aluno seria o que?

Alan - Não chegar gritando, agredindo o aluno moralmente, falando, tem professor que chega e só faltar colocar você abaixo de um cachorro, pior, escória da sociedade. Tem professor que não.

Artur - Pegando o exemplo do Fabiano mesmo, professor que tem, claro, o conhecimento muito mais avançado do que o nosso, só que não é só por isso que ele é melhor do que a gente, tem que tratar de igual para igual, mesmo não sendo igual, entendeu, mas tentando passar de uma forma que nos compreendemos, entendeu. Tipo, a gente tem que buscar o conhecimento, sim, claro, só que, numa linguagem nossa, com o respeito que a gente possa dar. Só que o professor tem que ser mágico: ele tem que saber a matéria, tem que ser dinâmico, é embaçado ser professor.

Agnes - Uma coisa que eu não concordo e que eu nunca concordei, por exemplo, o professor de química, você vai, pergunta pra ele, "quais são os critérios de avaliação que você usa, o que você pensa sobre a educação". "Não, meu negócio não é educação, é química". Então, aí fala isso. Eu nunca concordei com isso, "meu negócio não é educação", ele não é educador? Independente se ele é de química ou é de física, sei lá eu, ele tem que saber sobre educação, não é?

André - Acho que tem que ser mais simples do que toda esta situação.Tem que chegar na sala e fazer a proposta da aula. Ele tem que pegar e não massificar a sala, tratar toda a sala como se fosse um ser só.Tem aqueles alunos que dão um certo problema na aula dele, não permite dar aula nem como ele desejaria, acho que ele não tem que pegar e excluir estes alunos ou tratar de uma certa forma agressiva. Ta, o aluno não quer assistir a aula, ta causando algum problema, acho que deveria ver o porquê, pegar cada aluno especificamente e ver quais são os seus problemas, para saber realmente o que se passa, o porquê ele está fazendo isso, acho que ele não tem a intenção de estar atrapalhando a aula.

Juscilene - Tem alguns professores que, eu até já perguntei, eu cheguei para um professor e falei: "então professor tem alguns alunos que são difíceis de lidar", 
atrapalham a aula e eu não tenho paciência com aluno que não deixa eu prestar a atenção na aula. O professor tem que ter aquela compreensão, entender porque é uma pessoa que ta ali, com certeza tem problemas, com certeza ela tem um monte de coisas na cabeça como todo mundo tem. Ai a pessoa pega "não, o problema da pessoa é em casa. Ta aqui é outra coisa, eu não tenho nada a ver com a vida do aluno". Eu acho isso errado, porque para você ser professor, eu também já pensei nisso porque eu pensava em ser professora.

Eduardo - Não pensa mais?

Juscilene - Não, por causa do meu nervosismo. Eu preciso controlar isso, mas se for para eu entrar na sala de aula eu quero ter a compreensão do aluno e tentar entender ele e não me irritar e ser grossa com ele porque ele deve estar tendo um problema, deve estar passando por alguma coisa e a gente tem que entender.

Agnes - $\mathrm{O}$ adolescente por si próprio já é um problema.

Arthur - Mas esse negócio de tratar o problema de cada aluno, lógico é legal isso, muito bonito. Ce trabalha pra caramba, imagine você ficar 11 horas por dia, sala que muda de $30 \mathrm{em} 30$ alunos, e ter que tratar o problema de cada um assim, acho difícil para ele, acho que ele não tem nem uma estrutura emocional, uma estrutura toda para o professor fazer isso. Ninguém passa esta base para ele tratar assim. E fora que ele chega em casa e tem que corrigir matéria. Acho que é muito stress para ele ficar concentrando em cada problemazinho.

Juscilene - Não é tratar do problema, é pelo menos... você não precisa nem perguntar, sentar com ele, mas você ter a compreensão mesmo sem saber.

Alan - só o fato de saber dispersar o aluno do problema, direcionar a atenção dele na aula já...

Juscilene - Isso, você tem que entender que você está lidando com uma pessoa. Você tem que, eu sempre falo isso, você tem que tratar a pessoa primeiro como uma pessoa. Não importa se você é professor e ele é aluno, se você tem seus problemas, se ta nervoso e ele está te enchendo o saco.

Arthur - Cada pessoa é uma pessoa, mas a gente é o aluno e ele é o professor. A gente tem dez professores, cada professor tem duzentos alunos. Claro, tem que tratar como pessoa só que chega uma hora que é tanto aluno, tanta gente que ele não tem como ter esta particularidade, é uma massa, só isso, entendeu?

Agnes - Mas Arthur, foi ele que escolheu isso.

Arthur - Eu sei, é difícil, mas tem que ter muito amor a esta profissão.

Agnes - Uma coisa que não pode ser falada, por exemplo, o aluno tem que entender o professor, eu não coloco isso, porque o aluno é um adolescente, adolescente ta passando por várias fases, ta mutilado, a cabeça dele e ai ele tem que compreender um adulto que já passou desta fase, que já sabe mais ou menos o que quer e tal, escolheu isso. Como? Não dá. 
Arthur - Parece que tinha um milhão de coisas para ele fazer. No país em que a gente vive ele escolheu esta profissão só que talvez não tinha muita opções, era mais fácil para ele fazer na época, a faculdade tava barato. Não é que a gente tenha um monte de coisa para escolher, eu vou escolher a que eu amo. A gente trabalha de acordo que a gente vive.

Agnes - Mas você tem que levar em conta os seus valores.Eu não me dou bem com arquitetura, ta mais fácil, vou lá trabalhar com arquitetura, faço um prédio horrível, o prédio cai daqui dois anos, eu não vou fazer isso. Eu vou trabalhar com o que eu sei, com o que eu vou contribuir realmente.

Eduardo - Vocês acham que todos o professores que estão aqui no Ruth e em outras escolas escolheram ser professores?

Agnes - Não. Com certeza não.

Arthur - Um ou outro sim, talvez inicialmente ele até tivesse este pensamento, mas...

Alan - Eu acho que a maioria dos professores fez pedagogia porque é uma das faculdades mais baratas.

Juscilene - Antigamente o caminho era até mais fácil. Era só você fazer o magistério.

Alan - Eu me especializo em alguma matéria e pronto.Acho que está assim as coisas hoje em dia.

Juscilene - Mas tem a ver com o conceito que a sociedade impõe sobre o que a gente tem de decidir para o nosso caminho de profissão. Eu sempre fui muito criteriosa com isso, vou escolher um caminho...

Arthur - Mas você tem essa escolha

Juscilene - Só que agora $\ldots$

Eduardo - Agora, se você chegasse em casa, para o seu pai, sua mãe, e dissesse, pai, eu estou em dúvida entre duas profissões, eu queria ou ser advogado, fazer direito ou ser professor, qual dos dois eles Ihe apoiariam?

Juscilene - Advogado

Eduardo - Por quê?

Juscilene - porque ganha mais

Eduardo - Vocês acham que esta questão dos professores, que vocês estão falando, tem um pouco a ver também com o modo como a sociedade vê a profissão de professor? 
Juscilene - Como vê a escola e como vê os professores. A escola agora é um ponto de encontro. Eu vou linda, eu vou ficar com tal menino, eu vou ficar com tal menina, vou paquerar, e o professor não é visto como deveria ser. Eu acho que o professor deveria ter mais valor.

Eduardo - Não sei se vocês sabem responder, mas a maioria dos professores que dão aula aqui, moram na COHAB, são da COHAB?

Agnes - Não sei

Arthur - Alguns

Alan - Alguns moram próximos

Eduardo - Vocês acham que existe algum preconceito em dar aula aqui no Ruth?

Arthur - Entre o professores?

Eduardo - Dos professores em relação aos alunos?

Arthur - Morar perto

Eduardo - Na verdade assim, moram longe e tem que dar aula na COHAB...

Juscilene - Com certeza

Arthur - Tem história de professor que sai daqui e fala "ah nossa você da aula no ensino público"

Agnes - "COHAB, periferia"

Arthur - "Naquele inferno".

André - Ai mais uma coisa que eu acho errado. Essa coisa deles apontarem o dedo e falarem está horrível, as mesmas pessoas que poderiam estar ali influenciando naquela situação para que ela melhore, são as primeiras a apontar o dedo e falar que está uma merda.

Eduardo - Quem, os professores?

André - Os professores. Sabe, é muita fácil. Beleza, eu posso apontar o dedo e falar, todo mundo pode, mas quem é que vai ali se preocupar em me dar solução.

Juscilene - Ai você vê como os professores têm influencia no jeito que você trata um aluno, você passa para ele, eu acho ele pode influenciar na vida de um jovem.

Eduardo - E ele influencia inclusive nos conflitos que acontecem na escola?

Arthur - Na maioria das vezes sim. 
Eduardo - Ele é mais um apaziguador de conflitos ou mais um catalisador?

Arthur - Catalisador.

Agnes - depende do professor.

André - Vou dar um exemplo do que aconteceu comigo. Aconteceu um episódio em que um aluno, também aqui do Ruth, me deu um soco, por uns motivos ai bestas, ai o que aconteceu, ele me deu um soco, e eu fui falar com ele. Ai então o professor Fabiano foi conversar com a gente, com nós dois. Só que ele pegou e não defendeu nem eu e nem ele, foi ali e foi totalmente imparcial, e só esclareceu o que a gente queria, esta atitude, se permanecesse, o que ia dar, será que realmente era isso que a gente tava pensando, totalmente pros dois lados e isso é interessante. Tem ai um ponto de que ta sempre ai com a gente e tal, mas tem os outros professores também que eu converso

Arthur - O professor de artes ia fazer isso por exemplo, ia chegar pro dois e falar? $\mathrm{Na}$ boa, acho que o de artes ia falar "se matem lá fora os dois".

André - Acho que ele ia falar, mas tem outros professores, a professora Andréia de Física, a de biologia, a professora de inglês, direto eu estou falando para elas de apresentação de inglês que eu faço, e elas perguntam, conversam comigo sobre isso. E perguntam por que eu gosto, por que isso, por que aquilo, acho que tem assim professores que se interessam

Eduardo - Esses professores são maioria ou minoria?

André - Minoria

Agnes - Outra coisa que eu queria falar também é sobre a coordenação pedagógica. De manha até de noite é ridícula a coordenação pedagógica desta escola. Por exemplo, pode citar nome né? O Severino, ele é coordenador pedagógico, ele é muito firmeza, só que você vai falar com ele e ele vem com respostas prontas, altamente motivadoras, ridículas. Por exemplo, sexta feira os alunos combinam de não vir para a escola. $E$ toda sexta-feira acaba que não tem tido aula. Tudo bem. Ai uma sexta-feira, eu me irritei, vim pra escola, e fiz o seguinte, "Val", não tinha quase ninguém, a Val é a diretora, eu fui lá e disse "Val, eu não vou embora, eu vou ficar aqui e vou exigir aula dos professores". "Tudo bem, faça isso". Ai eu subi na primeira aula, entrou um substituto. Marcos o nome dele, de português. Ai ele pegou começou, ai falei para ele, "professor, eu vou ficar aqui na escola, tem pouco aluno, só que eu estou exigindo aula". Ai ele ficou quieto um pouco, "não eu to dando uma informação", não sei o que. Tava falando besteira, nada. Ai falei assim: "professor, você não vai dar aula". Ai ele falou assim a não sei o que, ai sentou. "Professor ce não vai dar aula?". Passou cinco minutos. "Professor ce não vai dar aula?" Ai ele pegou e falou assim. "Não, quero visitar o caderno de todo mundo". "Isso quer dizer que o senhor não vai dar aula?" Ai eu desci e fui falar com o Severino. Ai ele "ai eu entendo que você é uma aluna muito boa, eu sei que o seu caminho vai ser ótimo por toda esta vida, que você vai conseguir entrar na faculdade". "Mas eu não quero saber disso. Eu to 
perguntando se você não vai lá e fazer alguma coisa". Não era ele que tinha que fazer alguma coisa? Ai ele falou assim: "mas eu vou tentar resolver alguma coisa". Ele falou isso o ano inteiro quando eu fui reclamar dos professores. Ele falou isso o ano inteiro e ponto, ficou por isso, não falou nada. Não aconteceu nada e pronto.

\section{Eduardo - vocês se sentem menosprezados pelos professores ou coordenação?}

Arthur - Eu me sinto menosprezado pela coordenação. Por causa que a forma como eles trabalham é muito misteriosa. Eles não têm um foco, um objetivo, parece que o objetivo deles é simplesmente ter um professor na sala e vamos seguindo as regras da escola. Por exemplo, o professor não está dando aula, enquanto a tia está dando advertência ao aluno porque está de boné. Tipo as coisas bem assim, nada ver. É um trabalho muito esquisito que foca nos alunos, um exemplo, uma vez eu tava na sala e começou uma brincadeira muito, de um nível muito inteligente, de começar a tacar giz um no outro, as pessoas realmente muito espertas assim, tem que ter um QI bem elevado, ai eu tava assim, não sei o que aconteceu, acho que eu virei para o lado e veio um giz no meu olho. Eu fiquei muito fulo. Ai eu desci para cá, a cheguei, pra falar com o Severino, eu sabia que ele não ia fazer nada, eu já vinha preparado para isso. Ai eu falei com a Val. Ai a Val falou não sei o que, depois a gente vai resolver isso. E ficou por isso mesmo, entendeu. Ai depois eu desci de novo ai eu tava de boné. Ela quase me deu advertência porque eu tava de boné, mas se recusou a ir na sala, sei lá, eles podem fazer um monte de coisas, eles são a direção, ele tem que ter, não a solução, mas pelo menos uma base de que isso acontece, isso é uma escola, tem que ter uma forma de punir ou não.

André - Esses mesmos rapazes muito legais que ficam tacando giz acabaram acertando meu cabelo com chiclete. Bom, primeiro eu achei que era um giz, eu passei a mão e vi que tinha uma bolotinha no meu cabelo. Ai eu tentei tirar só que começou a embrenhar mais, eu tiver que pegar uma tesoura e cortar um teco do meu cabelo fora. Ai ficou um chiclete com um pouco de cabelo. Eu fui até a sala da Dona Val também, mostrei pra ela, falei, que os moleques tacaram, que eu tive de cortar meu cabelo fora para tirar o chiclete e ela falou amanhã eu resolvo. E acabou que não deu em nada. Como o Arthur disse, os moleques tacaram giz e acertaram o olho dele, isso foi depois, foi antes, mas os moleques continuaram tacando, acertaram outro menino lá. $E$ não resolveu nada e eu perdi o meu tequinho de cabelo.

Arthur - E eles não tomam atitude de nada e uma coisa que eu fico ferrado é com a sala de informática. Por que que fizeram essa porra, esse lixo ai, essa porcaria, pra enfeitar? Agora que a gente ta usando mais ou menos por causa do projeto. Só que chega antes do horário da escola não pode usar, é de enfeite. Eles aceitam esta verba para construir esta sala e a inclusão digital, meu onde é que vai isso. A gente não tem acesso ao teatro no intervalo, ou a sala de informática. Meu, um barato bem ridículo, parece que eles estão conservando a escola para nada. Para eles mesmos.

Juscilene - É completamente difícil você ir numa biblioteca. Você chega na sala de aula, o professor quer passar matéria, você tem que prestar atenção, ai você 
pega sai correndo. Outro dia, eu e a Agnes fomos no intervalo, a tia tem que sair da biblioteca e ficar no intervalo.

Eduardo - Não tem bibliotecária?

Juscilene - Ela é professora de português

Agnes - Não, ela é bibliotecária.

Juscilene - Mas ela sai da biblioteca, fecha a biblioteca, e fica no intervalo. (fim do lado A). A biblioteca fica fechada.

Arthur - Isso que eu acho muito estranho na escola. Essas coisas paralelas, fora da sala de aula, teatro, biblioteca, essas coisas são só pra enfeitar a escola.

Agnes - A escola é enorme. Tem teatro, tem sala de informática. Eu e o Alan trabalhamos seis anos direto na sala de informática, trabalhamos assim, a gente tentava fazer alguma coisa, mas chegou a ficar fora do nosso alcance, porque a gente tentava levar os alunos para lá, só o que acontecia a gente não tem, sabe, alguma proposta pedagógica, por exemplo, para a sala de informática. É uma coisa que a gente não tem como pensar nisso. E ninguém pensa.

Eduardo - Vocês não discutem com a coordenação isso?

Agnes - sabe o que é real, ela não sabe nada de pedagogia. Ela nem sabe o que que é isso.

Alan - eles falam assim: "chega no professor, pega o que ela ta dando, manda eles pesquisarem" lá. Qual o aluno vai querer fazer isso?

Agnes - Meu, a coordenadora pedagógica não sabe nada de pedagogia, não tem proposta pedagógica na escola, os professores não tem proposta das aulas deles, eles não sabem o que vai passar, chega um dia assim se você perguntar, professor, qual é a sua proposta este semestre... não façam isso.

Arthur - Não faz pergunta difícil.

Agnes - Eles não sabem, não sabem de nada. Tudo é largado. Professor eventual entra na sala sem proposta nenhuma, passa textos besta.

Arthur - O filme

Agnes - Nossa, o professor eventual passou um filme, nossa o filme é lindo, adorei o filme, sabe

Arthur - Minha mãe adora este filme, já assisti uma sete vezes.

André - Não tem proposta nenhuma.

Arthur - É um lixo. 
Arthur - "Um amor para se recordar"

Agnes - Nossa.

Arthur - A menina tem câncer e morre no final.

André -Poderia ter pelo menos uma proposta em cima deste filme.

Agnes - O filme é lindo, mas não tem nada a ver. E o professor de História que passou "O professor Carter". É o negócio lá dos EUA que o cara salva um time de basquete. O filme é legal também e ele estava explicando Revolução Industrial.

Arthur - Ano passado eles falaram porque que passou este filme. Era para os aluno que tava repetindo, pra levar o filme como motivacional, que nunca é tarde para desistir.

Agnes - Olha a estratégia, olha a estratégia.

André - Como é que é o nome daquele professor que entrou no lugar da professora de física?

Arthur - O bêbado

Alan - è um que tem seis faculdade, coisa assim, ta completando a sexta faculdade.

Arthur - Aquele lá que falou que sai na sexta-feira e só volta no domingo bem louco.

André - Qual é o nome dele?

Arthur - Eu não sei o nome dele

André - Outro dia...

Juscilene - Gilson, é Gilson gente.

André - O pessoal tava assistindo filme, este filme que acabamos de falar, e eu não queria assistir o filme, eu sai da sala, o professor não tava nem ai, deixou, não falou nada, ai eu sai, encontrei com esse professor que era para ele dar aula para gente. Ai ele não tinha aparecido na hora e ai apareceu o professor eventual. Ai o que aconteceu, eu encontrei com ele no meio ali do pátio, e pedi para ele subir na sala de aula, e dar uma aula para mim. Ele não quis. E falou que não, que não iria dar aula para mim, Ai eu falei não, eu quero aula, ai ele falou para mim, não, é uma atividade que eu vou passar, que vai avançar o que eu estava 
passando pra você, não beleza você pode passar aula para mim, não tem problema nenhum. Ai, não vou passar, vou passar pra sala toda. Ai então eu peguei e não lembro para onde que eu fui, acho que eu fui para a sala de informática, não lembro para onde eu fui, mas quando eu subi na sala de novo, ele tava dando aula para todo mundo, todo mundo tinha subido, e eu perdi a aula.

Agnes - Ta, isso é chocante, mas quando você pede aula, o cara tudo bem eu vim disposto a dar aula, chega e passa um texto na lousa que não vai te servir para nada, só vai gastar tinta e papel. E isso não tem o que fazer, porque o cara finge que dá aula, se você ficar sentado você finge que ta sendo educado, se você vai na coordenação pedagógica ...

Juscilene - Mas eu sou testemunha viva do que fizeram comigo e com a Agnes. $\mathrm{Na}$ oitava série, eu e ela era assim com os professores, professor, "olha o senhor tem que fazer isso, passa isso, não sei o que, vamos fazer aula, né e tal", a gente ficava lá, e houve até, não vou culpar, não sei se você exatamente a pessoa, mas geralmente sempre ocorria discussões porque os professores não toleram aluno dizendo o que ele tem que fazer. "Não, eu vou dar aula e pronto". Colocaram na minha fichinha: agitadora de sala contra professores. Agitadora de sala contra professores.

Eduardo - Quem colocou isso, professor...

Juscilene - Não sei que professor que foi. Minha mãe veio para cima de mim na hora. Claro, eu sou agitadora contra os professores. Passou, no outro ano, eu na turma $\mathrm{E}$ e a Agnes na turma A.

Agnes - No dia do conselho, tem uma mulher ali do prédio que ela participa do conselho, ela veio e depois ela falou pra gente. Quando chegou pra dividir a sala, viram a sala toda, "é a sala da Agnes e da Juscilene, separa as duas. De uma vez por todas, separa", que a gente estudou desde a quinta até a oitava. E ai, a gente sabe, falava muito e tal, falava com o professor e tal, a gente queria, sabe, discutir...

Juscilene - como ele avaliava...

Agnes - a proposta sabe, essas coisas, e ai ele não estavam dispostos a falar, e ai acontecia, a sala toda, não sabiam o que falar e causava mó conflito e tal. E ai eles pegaram e falaram: nossa, as duas, separa. Eles fizeram de propósito.

André - Eles não querem estas manifestações de individualidade. Só da uma olhada nesta sala. Grades nas janelas, as carteiras sempre uma atrás da outra, eu não vou olhar para ele, não posso olhar para ele do lado, ninguém olha para ninguém, o professor fica aqui na frente, ele fica de pé, fala para todo mundo, ele é o poderoso, o chefão, a imagem é maior, sabe, de princípio isso já causa um efeito.

Juscilene - Ao invés de pegar, fazer aquele círculo, vamos conversar, vamos 
trocar nossos conhecimentos, o que eu vou falar...

Eduardo - O que me chama atenção, você falou das grades, é que em todas as salas, os vidros são pintados até a metade. Você não consegue ver o que tem lá fora.

André - Pois é.

Agnes - Você vai perguntar obviamente eles vão colocar mó ideológico: não, é pro sol não entrar. Se fala isso, mas não se fala, engraçado, aqui embaixo não pega sol, porque aqui sol não bate, o sol nasce lá e morre lá. $\mathrm{E}$ em cima, onde o sol bate, tem umas coisas preta assim para o sol não entrar. Mas mesmo assim daria para ver. Eles falam que é para o sol não entrar.

Arthur - A gente se sente numa caixa. A gente ta aqui para aprender, você não pode se sentir livre e igual, você não é igual.

André - Pior é quando eu lembro que estas salas aqui não eram desta cor. Ai pintaram desta cor bem alegrinha, para parecer que é bonito.

Agnes - Uma coisa que eu fico me perguntando é a questão do Fabiano: que eu sei o preconceito que ele sofre com os professores. Nem na sala dos professores é impossível de conseguir ficar, eu já presenciei isso muitas vezes, ele entrando na sala dos professores, os professores são ridículos. Eles fazem brincadeirinhas totalmente horríveis, sabe. Tipo assim, ah e ai nerd, tipo, falam assim com o Fabiano.

Arthur - Os professores são pior do que alunos.

Alan - É verdade, porque eu já assisti um HTPC. É pior do que o aluno.

Eduardo - Conte um pouquinho esta experiência.

Alan - Tem uma professora da manhã, que você olha ela na sala, ela é o tipo de professora que eu falei que é ditadora. Ela agride os alunos moralmente. Um aluno saiu da sala e falou que ia no banheiro e ele chegou com um copinho de café. Ai ele levou este menino para a diretoria. Pegou ele, brigou com ele, xingou ele, ele foi no banheiro, pegou um copo de café, ai tipo essa professora, ...

Agnes - Aqui na escola o café é só para os professores. É isso mesmo.

Alan - É isso mesmo, tem uma garrafinha, água gelada, tem um filtro lá na sala dos professores, copo descartável,

Juscilene - E eles entram na sala comendo, bebendo, com coca-cola.

Eduardo - Na sala de aula?

Juscilene - Na sala de aula, a minha professora mesmo era frequente 
Alan - E ela faz vários.. várias... o sexo em si, dentro da sala de aula, é completamente extinto, o aluno abraçar uma menina, e essa professora, meu deus do céu, a coordenadora pedagógica não aguenta...

Agnes - Ela fala que vai no Motel com o Marido dela.

Alan - E a mulher pede a atenção, ei pessoal, presta atenção. Ai não sei o que lá, ai o caso do Fabiano, chega um professor assim igual ele, ao invés de falar direto pra ele, ai nerd, não, fala com alguém do lado para não ter que falar com ele, discriminando legal, muito infantil, pior do que um aluno de segundo ano.

Eduardo - O que vocês acham que incomoda os professores em relação ao Fabiano, por que que o Fabiano incomoda tanto os professores?

Agnes - Ele manja sobre educação, ele sabe do que ele fala, os alunos gostam da aula dele, e em questão do HTPC assim, quando ele está no HTPC, uma, a Sidelma, está falando, nossa, não sei o que, fui no motel, transei muito com o meu marido...

Arthur - Mas o que é o HTPC?

Agnes - Onde passa nota

Alan - Tem duas vezes por semana e é obrigatório para os professores.

Agnes - O outro falando de não sei o que, ai o Fabiano chega, "a gente, que não sei o que, tenho um assunto muito importante, nossa teve uma negócio de educação aqui, ele chegou assim aqui na escola, teve um negócio de educação muito dahora, que não sei o que, um boletim, saiu não sei o que, não sei o que, saiu uma proposta pedagógica de um cara muito louco", ai todo mundo fica olhando para a cara dele sem entender nada, e ele insistindo, sabe, insistindo, "vamo lá gente, vamo falar de pedagogia, vamo falar de educação", e não, a outra querendo falar do motel, gente querendo falar da menininha que pegou da outra sala, porque até professor pega menina da sala,

Eduardo - Qual foi a sensação de vocês dois, vocês não conheciam o HTPC, nunca tinham participado?

Agnes - não

Arthur - Você participou dele

Eduardo - Foi o professor Fabiano que convidou vocês a participarem?

Agnes - Não, a gente era da sala de informática, então a gente

Eduardo - Qual a sensação, existia uma imaginário sobre o professor, vocês imaginavam que os professores faziam isso no HTPC?

Alan - Eu não imaginava isso. Olhava o professor assim a imagem da perfeição, 
estudar muito, ai eu comecei a ver assim, depois eu vi que não era nada disso.

Agnes - Ah, depende, desde a sétima série eu já comecei a imaginar.

Alan - O que que aconteceu, eu comecei a ver que não era assim, como a gente estava dentro da sala de informática a gente tinha um contato além com os professores. A gente já via como eles eram assim mesmo, tipo, na primeira oportunidade que eles tem, nossa aquele aluno, ele não tem dinheiro.

Agnes - Ta no HTPC assim e ta falando o nome, ai a coordenadora pedagógica fala o nome, Amanda, quem é essa Amanda, a galinha, a bunduda, a que dá pra todos, é bem assim. Quem tem bastante coisa para falar sobre isso é o Paulo, o Paulo participou do grêmio, ele tentou fazer uma reestruturação assim teórica, do grêmio, tentou faze várias coisas aqui na escola, todo mundo bloqueou ele.

Eduardo - Paulo, fala um pouquinho do grêmio, qual que é o papel do grêmio da escola?

Paulo - Pegando um pouquinho ai este fio da conversa, eu tenho uma certa bagagem nesta área, já participei do HTPC, onde eu falei, tive a oportunidade falar, já participei de diversos conselhos de classe.

Eduardo - Por causa do grêmio?

Paulo - Já participava como representante do grêmio, mas eu já participava como aluno. Porque eu descobri que eu poderia estar participando de um conselho de classe. Ai sim eu tomei a iniciativa de pedir para a coordenadora participar.

Eduardo - Como você descobriu?

Paulo - Eu descobri através de professores, graças a Deus existem professores que pensam nisso ainda, professores, eu poderia citar, um dele foi o Fabiano, professor Nilton, eu ouvia ele falar, e a professora que dava aula de história aqui, a professora Isabel, e ai eu descobri realmente, e conversei com eles e pedi para a coordenação para estar participando. Eu quero participar do conselho de classe. $E$, realmente, aconteceu um choque, porque toda a imagem que eu tinha construído, ela desmoronou, isso foi muito proveitoso, foi uma boa experiência, mas em relação a isso é interessante, porque eu observo muito nos professores, observo que o maior problema da educação sejam aqueles que levam o nome de educadores, de mediadores, de tantos outros que tem por ai, porque eu ouvia o pessoal comentando aqui acerca do que ocorre no HTPC e no conselho de classe, nós podemos chamar isso de qualquer outra coisa, menos de pedagogia, especialmente porque, no conselho de classe, por exemplo, nós podemos fazer uma seleção de coisas horríveis, o aluno existem vários clichês, para diversos alunos, não se discute a pedagogia, a construção do saber, mas se discute na verdade se o aluno, é um aluno que tem um cheiro agradável, se é um aluno que tem talvez, uma família bem estruturada ou não, se é um aluno que sai com diversas alunas, enfim, discute-se tudo, menos o que é devido, e ai eu observei 
coisas horríveis, como vários apelidos que foram distribuídos, notas que foram adulteradas em cima da hora, por exemplo, um aluno tem lá três notas vermelhas em diversas matérias, ai eu estou observando aquilo, tomo isso como exemplo, filosofia, a aluno tem uma nota, por exemplo, d, os outros professores com os quais o aluno tem média e pergunta, como ele consegui esta nota, não pode ser assim, e ai o professor é pressionado a mudar a nota em cima da hora, a nota é mudada em cima da hora a pedido da própria coordenação.

Agnes - quando não é aquela coisa que eu falei de repetir, por exemplo, o aluno tem umas sete notas vermelhas, ele não pode ter, ai a coordenadora, né, que é o papel dela, será que não tem como vocês darem um cezinho para ele, ele tem que sair logo da escola,

Alan - Já aconteceu uma coisa comigo. Eu falo isso pra todo mundo, é a verdade, eu queria que estivesse assim no meu boletim. Fui aprovado pelo conselho ano passado e na ficha está que eu passei direto.

Eduardo - E você queria que estivesse, aprovado pelo conselho?

Alan - A verdade, e está assim é porque eu estou na sala de informática, tenho contato com a coordenadora pedagógica.

Eduardo - Você foi privilegiado então?

Juscilene - Sem contar que a escola se preocupa muito com a imagem dela lá fora, vamos pessoal, vamos fazer a provinha.

Alan - Um dia o governador veio aqui, a Agnes estava, o Geraldo Alckmin, o Paulo era monitor na época, os alunos ficaram trancados nas salas no intervalo, e cheio de gente bem vestida social assim, os alunos trancados na sala de aula, não foi Paulo, e os protestantes ali fora gritando.

Paulo - É importante falar isso: existem entre os professores uma clara distinção, entre os alunos que prestam e os alunos que não prestam, isso ocorre em conselho, em HTPC, em reunião interna, nas medidas da escola...

Eduardo - Como eles definem isso?

Paulo - Eles definem isso mais ou menos da seguinte maneira: o que não seria um aluno bom, seria aquele aluno que pressiona demais, o aluno que não cumpre com os seus deveres, entre aspas, quais seriam os deveres dos alunos: entrar na sala de aula quando bate o sinal, copiar devidamente a lição no seu caderno, resolver devidamente os exercícios propostos, e no final, ouvir o som do sinal novamente e se retirar em silencio, e este é o papel do aluno e todo aluno que não se encaixa neste perfil é tido como um péssimo aluno, mau aluno. $E$ existe esta clara distinção e o que ocorreu no dia em que o governador veio aqui foi exatamente isso. Ocorreu uma reunião que eu presenciei, estou falando porque eu presenciei, em que a coordenação da escola se reuniu e disse o seguinte, quais são as salas que podem assistir o discurso de governador, em dez minutos foi decidido, tal, tal, tal, tal, e as outras o que a gente faz, tranca os 
portões e mantém elas lá dentro. Elas foram mantidas lá dentro e só foram chamadas as salas selecionadas para assistir o discurso do governador, foram colocadas atrás, enquanto na frente estavam os diretores de outras escolas, e outros cargos a mais. Então essa operação foi feita em quinze minutos, para receber o governador e distribuíram bandeirinhas do estado de são Paulo, foi um show de ideologia, foi uma maravilha, e a gente viu de tudo ali, mas a grande verdade daquela situação toda era bem outra, a distinção entre os que prestam e os que não prestam.

Alan - Uma das salas escolhidas foi segundo A, uma sala onde a maioria dos alunos eram monitores da sala de informática,

Eduardo - Vocês falaram que tem um grêmio aqui na escola, ele funciona?

Agnes - Não, por exemplo, o Paulo mesmo ele era do grêmio, no ano passado, né Paulo, só que era o seguinte, posso fazer isso, porque você quer fazer isso, vai gastar dinheiro da escola, vai não sei o que, ai Paulo mas você quer tirar aluno para fazer não sei o que, você que fazer isso, você quer fazer aquilo, ah não dá. Tudo não dava. O que, você quer levar os alunos para o Play Center, claro, pro Play Center pode, pode levar,

Alan - Esta fita não vai pegar nada, né.

Eduardo - Não,

Alan - Vou fala uma coisa aqui que é da minha cabeça.

Paulo - A estrutura da escola é devidamente pensada para a repressão. Toda a estrutura ideológica e física, é pensada para isso. O que nos acabamos de falar, da estrutura das janela, dos corredores, que sempre mantém um fluxo e que não permite que haja, com que os alunos transitem com liberdade, não, a estrutura da escola é pensada para isso, a estrutura ideológica, também é pensada para isso. A questão do grêmio ela é muito forte, por que. Existe uma lei que regulamenta grêmio. E isso pega na esfera política da coisa. E a escola sabe disso, aqueles que dirigem a escola sabem disso. Sabe que se os alunos descobrem esta força política que o grêmio tem isso pode ocasionar diversos problemas. Então, eu vivi isso, porque quando eu propus uma reestruturação do grêmio, eu estava partindo do principio de que toda a escola, em assembléia geral, ela ficasse sabendo que o grêmio é uma instituição que permite que os alunos se expressem, é uma instituição legal, só que quando a escola descobriu isso, tive diversos empecilhos pra que isso não ocorresse.Entre eles: como realizar uma assembléia, com mil alunos no pátio, isso e inviável, foi a primeira fala que eu recebi da direção. A segunda fala que eu recebi da direção: vocês sabem, todo mundo sabe, os alunos não tão nem ai pra nada, então pra que começar este trabalho.

Juscilene - Olha o interesse da escola no modo como a gente vê as coisas. $O$ interesse da diretoria no modo como os alunos vêem as coisas. Pra que, mas eles não estão fazendo nada, pra que se interessar por alguma coisa, falando isso.

André - O que acontece é uma domesticação dos alunos. Você faz tal coisa que 
não agrada os superiores, você é punido, assim você sabe que não deve fazer mais.

Agnes - Inclusive, no ano passado, eu tava falando com o Fabiano, que ele tinha, era totalmente preconceito com ele, eu e o Paulo a gente sofreu também este preconceito porque a gente conversava muito com o Fabiano, e assim, nas aulas, a gente era chato, e o que acontecia, sofria um forte preconceito, qualquer coisa, que a gente falava na sala de aula, por mínimo que seja, ah essa arrogante de novo. Arrogante, este negócio de arrogante, já vi isso tanto que não aguento mais.

Paulo - Eu já ouvi esta mesma colocação, arrogante, a coordenadora da escola, você tem que deixar de ser arrogante, tem que ser mais humilde, ficava implícito nas frases dela que eu deveria entender que o professor é o superior,

Agnes - Ou seja, cala boca, o arrogante quer dizer, você deve calar a boca.

André - Eu queria ouvir o Alan falar

Alan - Eu e a Agnes nós passamos muito por isso, tipo, queimou uma peça na sala de informática. Precisava comprar uma peça para o computador. A gente ia na direção. A gente ia precisar de tanto para comprar tal peça. Bom é o seguinte, a gente não tem o dinheiro, envia o email para os caras que podem doar, de tal empresa, para dar, mas numa devida situação em que a gente foi fazer um vídeo no parque do Carmo, a gente acabou danificando um aparelho de uma professora. Mas na mesma hora, não sei de onde a direção tirou este dinheiro, porque para comprar peça para a escola não tinha, mas para comprar este negócio desta professora tinha, ela arrumou 50 reais sendo que o cabo era dez reais.

Agnes - Deu 50 reais na nossa mão e disse, vai lá e compra.

Alan - Vai dar o dinheiro, precisa de mais, falou bem assim, a Agnes ficou impressionada. E comprou o cabo e tudo. E hoje eu fui falar com a direção e eu vou contar para vocês onde eu penso que vai este dinheiro. Agora esta semana que passou, eu estou com três computadores sem funcionar, três placas de som queimada, uma de rede e três botões que estão com problemas. Ai eu cheguei na direção eu preciso disso. Tem um empresa, o email é esse.Tipo, hoje eu fui buscar minha irmã na escola, e eu olho para o lado e está a casa da diretora, a casa dela está sendo totalmente demolida, está levantando uma mansão, do lado da casa dela tem um espaço de lazer, totalmente zen, todo de bambu, em dois andares. $E$ do lado tem um terreno enorme, que se eu não engano é dela, eu não tenho certeza. Eu estava pensando isso hoje, eu não estou afirmando isso, eu acho que sei agora para onde vai este dinheiro.

Agnes - Não play Center gente, play Center sobra mais de quatrocentos reais, não é, sabe o que eles fazem com quatrocentos reais, churrasco no final de ano para eles.

André - teve um dia que estava tendo um negócio de recolher prendas para a festa junina. Tinha lá todos os brinquedos também que eram recolhidos no 
período da tarde, e ai eu tava de monitor na escola, eu estava fazendo a contagem e arrumando tudo, e ai teve a festa na casa da diretora, que é essa casa que o pessoal tava falando, ai eu fui lá, que ela me convidou, eu apareci lá na festa, ai ela me deu um bloquinho - essa fita não vai...

Eduardo -Deixe eu explicar, na hora da transcrição os nomes de vocês viram nomes fictícios. Essa é uma regra da pesquisa, você não expõe o entrevistado.

André - Ai eu ganhei um bloquinho, que era um bloquinho de bingo, e falou que eu era pra vender cada folhetinho por um real, pro pessoal da festa. Ai eu falei, posso ver o que será vendido, ai eu fui lá ver e eram todos os brinquedos que os alunos haviam arrecadado de prenda, que era pra festa da escola.

Neste momento, a fita se interrompe. O Professor Fabiano entra.

Fabiano - ... Foram lá, a vice-diretora me chamou, porque eu devia ter comunicado a direção, a coordenação e os professores e não deveria ter feito uma reunião sem comunicar ninguém. $\mathrm{E}$ o Juarez foi lá reclamar que vocês vão ficar sem nota, não sei o que...

Agnes - Mas a aula dele é a terceira.

Fabiano - Terceira começa oito e meia, né. Mas ele já foi lá. Então não sei se vocês vão continuar.

Paulo - Um das primeiras aulas de filosofia de verdade que nos tivemos aqui na escola com o professor Fabiano ele falava sobre esta questão do espaço público e do espaço privado. E a grande frase da nossa escola, da Ruth Cabral Troncarelli é que aqui realmente se transformou num quintal, o quintal da nossa diretora, e isso vem a calhar com aquilo que nós estamos falando. $E$ isto é mais uma demonstração disso, porque a escola deixa de ser pública e passa atender interesses privados.

Agnes - Tanto é que ela levou um monitor da sala de informática e não trouxe até hoje.

Paulo - São interesses privados, são interesses pessoais. A escola deixa de ser um espaço de todos e passa a ser o espaço de um grupo só.

Eduardo - Então para não prejudicar vocês, a gente pode continuar outro dia, por enquanto está maravilhoso, vocês falaram muitas coisas, tem muita coisa que ficou na minha cabeça,

André - A gente pode escolher os nossos nomes fictícios.

Risos

Eduardo - Pode.

Fim da Fita. 


\section{Entrevista com Coordenador Pedagógico da EME Prof ${ }^{a}$ Alcina Dantas Feijão.}

Eduardo - Eu gostaria de saber um pouco sobre como você pensa a educação em relação a formação continuada dos professores e queria também que você falasse um pouco da sua história e do seu tempo aqui no Alcina.

Paulo - Então, eu comecei aqui, Eduardo, como professor eu vim substituir uma professora, por que sou professor de educação física também, eu estava voltando de São Carlos, por que eu trabalhava na Universidade Federal de São Carlos (UFSC), vim para São Paulo mais ou menos na época do plano Collor, como eu estava desempregado, tinha apenas algumas aulas, vim substituir uma professora aqui e ai fiquei quatro meses dando aulas de educação física infantil no magistério, e ai no ano seguinte teve um concurso para professor de educação física, prestei, passei no concurso e na verdade eu ia desistir, não ia começar por que não me interessava, eu já estava na pedagogia. E nisso estava mudando, a dona Terezinha estava saindo e estava entrando um outro diretor chamado professor "Shimizo", que hoje é até assistente do "Cop", e como estava abrindo o Alcina 2, ele me convidou para começar na coordenação pedagógica de $1^{\circ}$ à $4^{\circ}$ série, e eu comecei junto com a dona Marilena, não sei se você já conheceu, nós ficamos lá a escola era pequena, depois de um tempo ele criou de $5^{\circ}$ à $8^{\circ}$ a escola foi aumentando. Muito bem, em 1997, eu já tinha terminado o mestrado, quando entrou o professor Pacífico na escola, um japonês já falecido, e ai ele me tirou de lá e me trouxe para cá, eu assumi a assistência e a coordenação geral, a escola era muito grande, nós tínhamos 6 mil alunos, era uma loucura isso aqui, tínhamos 3 orientadores, aquela coisa toda. E de lá para cá eu estive nessas duas funções com ele e depois com a dona Arlete, que foi uma outra diretora que veio e ficou 4 anos também e enfim nós estamos dando continuidade a esse projeto e ai então entrou a dona Terezinha, mudou o prefeito, mudam-se as linhas políticas, mudam-se as filosofias, etc., e ai ela me convidou para coordenar o Ensino Médio, que é o que eu estou agora.

Eduardo - E dentro do papel da coordenação do ensino médio, uma das discussões que eu estou fazendo na minha dissertação é a questão da formação continuada dentro da escola. Como você avalia isso aqui no Alcina?

Paulo - Vou tentar fazer uma trajetória, quando nós começamos aqui em coordenador em 1993, não tinha formação de professores, a escola sempre foi muito bem conceituada, por que ela cumpre uma função política também, mas eu não queria entrar... na cidade ela é uma... ela cumpre uma função política, tem muito vereador que pede vaga, aquelas questões todas, mas não tinha formação de professores, em 1997 quando o Pacífico assumiu, pela primeira vez... já tinha formação de professores em todo lugar, todas as escolas faziam formação de professores, então nós pensamos em um projeto que tinha dois canais bastante claros, um deles era a entrada de coordenações de áreas na escola, que também não tinha, a Maiberte pegou ciências e tecnologias que é área do ensino médio, a Denise pegou ciências da natureza, tinha a área de história etc., e matemática não me lembro. Então, tinha um propósito, começar com as coordenações de áreas, por que era muito grande, tudo muito grande, tinha de 150 a 200 
professores, médio e fundamental, duas unidades. E pensamos por outro lado a formação de professores, eu escrevi esse projeto, até estava junto quando o Pacífico levou ao prefeito, inclusive já falecido, e era uma estrutura grande, ela visava o seguinte, o professor teria 8 aulas, 2 tardes de formação na estrutura geral e teria uma outra parte de formação que nós conseguimos que estava ligada a essa área, porque por exemplo, não existia computador na sala dos professores, não existia disponibilidade de laboratório, tudo isso nós fomos criando naquela época. $\mathrm{Na}$ sala dos professores a previsão inicial era de 8 computadores para os professores trabalharem, ninguém nessa ala tinha computador e eu trazia Lap Top e as pessoas achavam que eu era fresco: "você é maluco!", isso em 1997, mas a escola já tinha tido um projeto que eu trouxe para cá para São Caetano, chamado "Escola do Futuro", não sei se você conhece, falava da ECA não sei se ainda continua, em 1993 teve em São Caetano. E ai nós começamos, mas na hora de debater eu mostrei para o professor Edson vocês têm duas aulas e foi o que ficou de lá para cá, o Pacífico não tinha uma força política para mexer com isso, a Arlete que veio depois também não, enfim conseguimos duas aulas, porque antes disso também, não tinha nada, nada, não existia formação de professores, não que se de para fazer alguma coisa com 2 aulas.

Eduardo - Vamos pensar nesse caso com 2 aulas, ela é concebida como na sua opinião, essas 2 aulas?

Paulo - Então, a gente pensava desde o início em trabalhar com os professores por projetos, era uma idéia que vinha já do pacífico, que era um diretor cuja linha era que os professores participavam mais, sugeriam mais e a formação se dava assim, então eram vários projetos com um projeto central, vamos dizer "guardachuva" que era o que a gente chamava de interdisciplinar. Então esse projeto "guarda-chuva" alimentava os projetos intermediários, então a formação dos professores era pensada a partir desses projetos, eles se reuniam, estudavam com os coordenadores, as meninas traziam subsídios... artigos, etc., que podiam ser discutidos, nada muito grande, porque lembrando são 2 aulas, e nenhum diretor perde a característica de querer fazer do "Help" um local de dar informação, de ir lá e ficar lendo: "essa semana vocês têm que fazer isso", isso nós não acabamos ainda. Ai veio a Arlete, como ela era uma pessoa bastante compreensiva continuou nessa idéia, então a formação dos professores era feita a partir do que a gente tinha que fazer na escola, dos projetos que a gente tinha, das necessidades que a gente tinha, etc., isso você já sabe mudou um pouco, mas a primeira concepção de fazer formação de professores eram 8 aulas, era um tempo para o professor poder preparar a atividade.

Eduardo - E a relação dos professores com esse tipo de formação? Por que chegou um momento que não tinha e que depois simplesmente aparece.

Paulo - Então a gente tinha ai 3 grupos muito claros, que eram os que apoiavam, que se interessavam por isso, um grupo que ficava ali no meio da rua, quando a coisa era muito interessante eles vinham e um grupo resistente, que até hoje existe, as pessoas que acham que tudo isso é um "blá blá blá".

Eduardo - E nesses 3 grupos tem algum perfil dos professores? 
Paulo - Interessante. Eu não consigo te dizer por exemplo, que os professores que acreditam mais que a escola possa ser um local prazeroso, um local de realmente construir pessoas, eu não te digo que esses professores eram todos novos, uma vez já me ocorreu de querer fazer uma ligação simplista do tipo que os mais novos são mais inovadores, não é verdade tinham professores antigos também que estavam ali. O que eu descobri com tempo, muito interessante, é que os professores têm propósitos pessoais e muitas vezes o que a gente pensava em termos de formação estava muito distante do propósito que ele tinha para aquele ano, e isso não era uma forma de resistência, ou seja, a resistência era legítima, ele já tinha alguma outra concepção do que ele ia fazer etc. o princípio dava muita dor de cabeça, a gente ficava chateado: "Pô, o cara esta resistindo!", mas por outro lado ele estava caminhando também, então eu não sei se mais novos são... nunca fiz essa ligação.

Eduardo - Será que tem alguma coisa a ver também com a formação inicial na universidade, o que ele passa no início da carreira ou o tipo de curso que ele fez?

Paulo - Tem alguns estudos muito interessantes que mostram o seguinte, o sujeito é na sala de aula um pouco do somatório do seu processo de formação, ele está sempre se formando, é um processo, muito do que ele é na sala de aula, muitas vezes foi do que ele aprendeu lá no ensino médio, enquanto aluno, ele reproduz a forma de organizar as carteiras etc., muito da formação inicial, e a gente têm que tomar cuidado com a formação inicial por que muitas vezes ela é em alguns cursos, muito deficiente, em outros cursos ela é muito boa, então eu acho que a formação inicial...e eu falo as vezes isso para o meu filho: "Se você fez uma faculdade paga, tudo bem, se você fez uma faculdade pública que você consegue ver o ambiente acadêmico, que você consegue ver o que é pesquisa, se você tem professores... claro que isso vai te por em marcha, e ai se você pegar a maioria dos professores aqui, tentando entender por esse lado que você falou, a maioria dos professores foram formados em universidades particulares, algumas delas sem a mínima preocupação com pesquisa na faculdade.

Eduardo - Um dos elementos que perpassam no meu trabalho também é a idéia do professor pesquisador. $O$ que você entende como dificuldade para essa proposta de professor pesquisador, como você vê isso dentro da escola?

Paulo - Você já deve ter me ouvido falar, acho que falei isso na nossa última troca de experiência, se você pode fazer da tua prática seu contexto de pesquisa isso é fundamental, quem fez isso foi a Marisa, quer dizer passou o tempo pesquisando, analisando o aluno, comparando, isso é interessante, mas não é o que todos os professores tem como propósito, você pega muitos professores que não tem o mínimo interesse nessa questão de...

Eduardo - ...Uma reflexão sobre a prática.

Paulo - Não, não tem.

Eduardo - Eu vejo por outro lado, eu não sei também se existe um preconceito da própria universidade em temas relacionados a isso, por exemplo quando você pega um professor do ensino médio que se coloca a pesquisar sobre a sua 
prática "isso não é pesquisa", "isso não é saber científico".

Paulo - Talvez nós estejamos falando de duas coisas, duas formas de formação de professores, uma delas é a pesquisa mesmo e a outra é a reflexão, essa linha da reflexão surgiu por volta de 1990/92 com um cara chamado Schönn, um americano, que não era da área de educação era da área de artes, e ele escreveu pela primeira vez sobre o profissional reflexivo e ai isso virou um "bum" na educação, que não é uma coisa muito moderna o Dewey já falava disso naquela época, de você pensar sobre o que você faz. Essa é uma linha, de você refletir sobre o que você faz, sem o caráter acadêmico da ciência, e a outra linha que tem muita gente no Brasil que defende que é realmente você pesquisar, usar como pesquisa e o debate é grande por que tem gente que diz que a essência da profissão do professor não é pesquisador e tem gente que diz não é não você pode fazer.

Eduardo - Tem gente que diz que é preciso pesquisar para ensinar.

Paulo - É. Você entendeu. Eu acho que as duas coisas podem ser...quando você não esta preocupado em pegar os conteúdos e passar para o aluno, está mais preocupado em fazê-lo entender, você esta mais solto daquilo ai você pode trabalhar com os alunos, pesquisar, analisar, por que você precisa ter o domínio da sala, um domínio bom dos conteúdos, do que você quer lá na frente pra poder entrar ali na pesquisa.

Eduardo - Falando dessa questão da pesquisa, a escola também precisa criar um ambiente para isso, alguns elementos importantes e eu vejo um pouco disso nas trocas de experiências que a gente faz. Eu gostaria que você falasse um pouco sobre o que é.

Paulo - É verdade, aqui a escola é política e isso, quer queira quer não queira, muitas vezes determina o que as pessoas fazem, então a gente constrói, ajuda a construir o que as pessoas fazem e nesses antigos diretores a liberdade pedagógica era muito grande, então nós fomos pensando em ferramentas que pudessem ajudar o professor na formação e uma delas tem que ser a escola, as pessoas se interrogam (interrompem) muita coisa, como podem ajudar, entendeu... podia ajudar a moça a resolver o problema..., mas a maioria das vezes na escola se tenta colocar um obstáculo para deixar a pessoa... então a gente pensou em diferentes ferramentas que pudessem ajudar na formação dos professores, ou seja, a tecnologia não é determinante, mas tentamos colocar computadores, tinha até uma planta de como seria a escola, computadores, laboratórios para os professores, pensamos nessa formação por projetos com coordenadores por área, enfim, para tentar ajudar a fazer essa formação dos professores que era 8 aulas de início que nós queríamos. E uma outra estratégia foi a troca de experiência, que começou acho que em 2000/01 alguma coisa assim, e era feita dessa forma, ou seja, o sujeito desenvolvia um trabalho ao longo do semestre, ele pensava sobre aquilo, refletia, escrevia, eu sempre fiz questão da parte escrita, por que a escrita é clínica, quando você escreve, você pensa sobre o que você está escrevendo, você está escrevendo para o outro, o outro esta te olhando, e ai o sujeito pesquisa um pouco, não é nada muito 
academio, mas serve um pouco, você escreve um resuminho no estilo acadêmico, tem ali um corpo, uma bibliografia, os professores apresentam lá na frente, defendem os seus pontos de vista, mas você pode reparar que não é ainda... as pessoas se escondem um pouco da pergunta de um colega, eles vêem aquilo como um ataque, mas não é um ataque falar "Poxa, eu queria fazer uma pergunta, olha eu não concordo...", isso nós ainda não chegamos.

Eduardo - Não chegou ainda nessa troca, né?

Paulo - É. Nisso ainda não chegamos. E muitos professores que tem muita bagagem, já fez muita coisa, não apresenta, eles tem um medo de ser julgado, muito forte.

Eduardo - É uma questão muito importante da auto-imagem.

Paulo - É. Você vê o Vladimir é um professor que já esta se aposentando, nunca apresentou, e ele tem... todo ano ele trabalha com um projetinho, mas ele nunca, ele fala para mim: "Paulo, estou me aposentando, não quero, não penso em formação de professores". Aliás uma coisa interessante que eu achei de um cara chamado Hubberman, um francês, ele trabalhou com a carreira dos professores, ele viu que os professores têm uma fase no início da carreira, de sobrevivência, que o cara tem que se virar, depois ele tem uma fase em que investe na carreira como um louco e ai ele tem uma fase de desaceleração, os caras que estão próximos também não querem muito saber... uma vez eu conversava com ele (Vladimir), por que eu cheguei a entrevistá-lo e ele dizia: "Eu não quero mudar mais o jeito que eu faço, eu faço assim, eu participo dos projetos", então já ta... fica uma coisa assim: "Eu faço o que vocês querem, mas não me encham a paciência!" (risos), ele nunca fez uma apresentação na troca de experiências, e hoje a gente tem a questão dos certificados, tudo bem, mas antigamente a gente não tinha os certificados, e a gente sempre teve 15 trabalhos, então fazia parte das estratégias para formar professores.

Eduardo - E a Escola do Futuro também era uma tentativa de aproximar a universidade da escola ou não?

Paulo - Não. A Escola do Futuro, na época eu era pesquisador da ECA e surgiu a oportunidade de uma parceria, porque na época eu estava muito próximo aqui da diretora Márcia Galo, então eu falei como é um projeto muito bom, vamos trazer para as escolas, por que em 1993, imagine você que pouquíssimas pessoas mexiam com internet fora da universidade, aqui o monitor era de fósforo verde, era 286, para você baixar um e-mail precisava conhecer os comandos Linux, que era o Linux para PC, precisava conhecer alguma coisinha, mas trouxemos, trouxemos porque era um projetinho que os meninos iam analisar a água, medir a água do rio, media $\mathrm{Ph}$, depois mandavam isso para escolas em Israel etc., isso causou... nem os professores aqui, porque eu ainda estava em outra unidade, apoiaram o projeto: "Ah! Esse negócio de internet não vai nem pegar!", depois de uns 4 anos ninguém nem mais fala disso, mas não era, isso foi antes. O que a gente tentou foi principalmente dar um numero grande de aulas para o professor fora da sala, e eu tive que ouvir muitas vezes sabe o que : "Para que o professor 
ficar fora da sala, fica com 8 aulas, só batendo papo", o que as vezes pode até acontecer, mas se você tem um tempo maior, você pode...

Eduardo - Há ainda um imaginário muito forte de que a relação pedagógica só acontece em sala de aula e de que é só necessário que ali aconteça e que fica claro nisso.

Paulo - E os professores daqui são bons.

Eduardo - São! Eu ia perguntar para você exatamente isso, para você falar um pouco sobre os professores.

Paulo - Os professores daqui Eduardo, eu tiro o chapéu. Eu tive uma fase muito interessante, enquanto coordenador, que é aquela fase de querer mudar o sujeito, "vocês precisam mudar as suas aulas", depois teve um período que eu estava muito na sala de aula com os professores e eu comecei entender que eu conhecia pouco da realidade da sala de aula, tudo bem, eles precisam mudar muita coisa, mas eu passei a compreender muita coisa que eu não compreendia e ai eu percebi que você tem, por exemplo, o Aguinaldo, você tem professores muito bons, você tem a Denise, a Maiberte o corpo docente, ele é um corpo docente... agora como é uma escola pública isso eu acho que falta, é que toda hora a descontinuidade é forte, então estamos trabalhando com um projeto, nós temos a monografia, que também ajuda o jovem, tem a alfabetização emocional, que é quando a gente quer tirar, que tem gente que acha que é perfumaria: "por que o importante é a matemática!".

Eduardo - Ai entra uma das questões também que surgiu no meu trabalho analisando já o Alcina e a outra escola, que é ver essa relação da escola com a política e com o poder, e eu fico pensando que em São Caetano é muito presente isso, principalmente no Alcina por causa dessa questão de ser uma escola tradicional, não é?

Paulo - Quando eu entrei aqui, eu também não conhecia essas relações de política, eu comecei a conhecer na prática, mas vi que é muito presente por que, a escola é tradicional na comunidade, a comunidade participa, a comunidade "vira e mexe" vai reclamar do prefeito...

Eduardo - E no caso do Alcina não é só a comunidade do bairro, é a comunidade da cidade.

Paulo - É. Da comunidade da cidade. Quando eu entrei aqui as pessoas me diziam que ela era a menina dos olhos da cidade e realmente era, eu acho que ainda é, os professores ganhavam muito bem, hoje nem tanto, mas ganhavam 5 , 6, 10 vezes o que os professores do Estado ganhavam na época, quando eu entrei aqui. Então essa relação de política esta presente em todas as escolas de uma forma ou de outra, mas aqui ela é bastante... e ela determina, por que, mudou o prefeito muito bem, muda a secretária de educação, muda o diretor da escola, o diretor, o que ele faz, muitos deles chegam e olham quem é a parte técnica, alguns aproveitam, outros trazem o pessoal deles, e ele vem com a linha dele, ele quer apostila, ele quer... agora, isso muda um pouco, eu disse isso para 
os professores no primeiro dia, isso muda um pouco porque a sala de aula é muito complexa, você pode estar com a apostila lá, mas você faz da apostila aquilo que você quer, só alguns professores que ficam ali seguindo... então o resultado da escola é difícil de perceber, mas é ... por que, tem professores bons, enfim, hoje já se aceita mais projetos, no início não se aceitava, então isso fatalmente acaba com alguns projetos, surgem outros, algumas coisas depois de um tempo fazem a mesma coisa só que com outro nome.

Eduardo - Pelo que eu analiso, talvez o único problema seja o fato de que as vezes os professores se sintam meio que desvalorizados em certo sentido, quer dizer, muda, e qual que é o meu papel na escola.

Paulo - Isso é verdade. É menos valorizado e ai você não valoriza o sujeito que leva a escola. Se você vai em um hotel você não vê o gerente, você conversa com a camareira é ela quem dá a cara do hotel por que é ela quem arruma a sua cama e na escola é o professor, então ele deveria ser o sujeito mais valorizado, não deveria ter 8 aulas de "help", mas 10 aulas por semana, para ele sentar pensar, mas as pessoas não pensam assim.

Eduardo - E se você for analisar do momento que você começou a trabalhar com os professores, você sente que há uma mudança nessa relação do que era o professor na década de 1990 do que é o professor hoje 2007, no sentido das suas práticas, do que ele faz?

Paulo - Eu acredito muito que eles mudaram, eu digo que eu mudei minha maneira de ver a educação, mas eles também mudaram, quer dizer não foi assim... eu não sei se é uma mudança, a gente tem que analisar o que é mudança e se a inovação traz realmente uma mudança, mas enfim, hoje quase $100 \%$ do corpo docente utiliza a informática, desses $100 \%$ que utiliza a informática eu diria que $40 \%$ utilizam na sala de aula ou no laboratório, a Clarice, você, a Maiberte, muitos professores vão no laboratório, agora se isso é um resultado positivo ou não, não dá para dizer, mas é uma evolução, estão usando novas ferramentas, então os professores estão... depois nós começamos com o projeto da Intra, aquele troço, que tem uma resistência grande, mas com o tempo, só que é lento, são 5 anos, 4 anos as vezes pra você... e ai quando uma pessoa está entrando no troço, muda, isso é... até os mais resistentes, porque o que acontece, toda escola tem uma cultura, toda escola é mais alegre ou mais triste, mais respeitada, menos, tem sistema de avaliação aquele, mas ela tem uma cultura e essa cultura tem um núcleo sólido, se você disser aqui que vai colocar por exemplo a progressão continuada, os professores vão te bater, isso é sólido, mas isso também foi com o tempo foi... hoje você pega o conselho de classe, eles analisam um pouco mais o aluno, quando eu entrei aqui, eu me lembro bem, o aluno ficava retido por 0,000 : "Não interessa...!", mudaram, mas devagar.

Eduardo - Como a gente falou um pouco da coordenação, como você concebe o seu papel de coordenador, como você pensa essa sua ação como coordenador?

Paulo - Uma vez eu falei uma palavra, que eu continuo com os mesmos princípios, eu faço isso, mudou diretor, entrou diretor, eu continuo com os mesmo princípios, eu considero, até já escrevi um texto sobre isso, o coordenador é um 
ajudante. Se eu tivesse que definir a palavra, seria um cara que procura facilitar o trabalho do professor e ai vale tudo, desde de você ter que montar um data show se o cara ainda não aprendeu a montar, discutir um pouco essa ou aquela relação, fazer uma orientação, chamar o sujeito na hora que é preciso você explicar para ele ver a escola um pouco, porque as vezes a pessoa esta ali, mas ela não tem a noção do todo, mas eu acho que a função do coordenador é essa, tentar fazer o cara pensar, uma estratégia que eu uso bastante é assim, o sujeito sentou na minha frente aqui, você vê nós temos no ensino médio umas 60 professoras, sentou na minha frente leva um pouco de pedagogia, não sai sem uma explicação técnica da pedagogia e nos "helps" eu tento... eu tenho dificuldade nos "helps", eu já assumi isso, porque eu não conheço o conteúdo, eu não conheço história, eu não consigo fazer formação sobre história. O que a gente fazia antigamente com quem era da área, então a Denise... ela tinha, não é... ela conhecia, então eu tento levar texto, tento... fazer uma formação que possa... mas o coordenador na minha opinião é o cara que está com os professores, você tem que estar com seus professores: "qual é o problema, é esse, é aquele... vamos resolver esse problema aqui", e uma coisa que eu acho que fundamental no coordenador é trabalhar em confiança, e nisso me criticam muito, porque eu vejo assim Eduardo, se você... "você tem que ver o que ele está dando na sala de aula, você tem que olhar o diário", você põe o que você quiser no diário, você escreve o que você quiser, claro que a função do coordenador também é olhar o diário, mas tem que ser estabelecida uma relação de confiança, por que o professor faz o que ele quiser, lá em cima o que ele quiser, se o coordenador aperta muito ele é capaz de dar 5, 6, 7 capítulos rapidinho para acertar o conteúdo, se o coordenador diz que ele está muito rápido ele desacelera ao extremo que é para... se o passo aperta ele... e o que ele faz, ele não te conta, se você tem uma relação de confiança boa, que eu tenho muito, você chega aqui e fala: "Paulo, aconteceu isso, como é que posso...". isso eu comecei aqui assim, claro que eu amadureci em todos esses anos e agora eu estou dessa forma.

Eduardo - Só para terminar, você percebe no outro lado da relação, dos professores com você, essa confiança?

Paulo - Eu percebo que há um... eu não sou um unanimidade, ninguém é, embora muitas vezes já, os professores me indicaram para que eu seja o diretor da escola, eu já vivi momentos aqui... eu já tive problemas, mas enfim, eu acho que a grande maioria... um grande número de professores, eu tenho uma relação, trabalho com essa relação de confiança o sujeito fala, não precisa esconder, você vai me ver poucas vezes dando uma bronca no sujeito aqui, e ate para dar bronca eu chamo na minha sala, elogio a gente faz em público e bronca a gente faz... então eu acho que há uma proximidade, hoje eu não consigo fazer o que eu fazia, essa questão de uma nova política também te põe limites, mas eu não trai meus princípios e nisso eu fico contente, eu continuo acreditando na relação de confiança, eu continuo acreditando que é possível, continuo tentando motivar o sujeito.

Eduardo - A sua pesquisa, do ponto de vista universitário está dentro dessa lógica de pensar as suas práticas?

Paulo - Mas eu não trabalho especificamente, com pesquisa na escola, eu não 
consigo, já tentei, mas eu não consigo me distanciar o suficiente para pesquisar, então a minha pesquisa, eu tentei publicar algumas coisas, mas eu sempre... o meu viés fica... então agora eu estou trabalhando com formação... eu trabalho como professor de ciências, formação de professor de ciências à distância, então não mexo com a escola, mas o que eu faço é objeto de reflexão minha, constante, ainda hoje estava: "É nos vamos mexer aqui na aula de 50 minutos, vai cais para 45 não pode", eu disse, mas onde esta escrito que não pode? qual é a lei? vamos procurar? Aí correrão: "É não existe, realmente não existe", quer dizer isso eu continuo.

\section{LADO B}

Continuação...

Paulo - Isso ocorre por que você adquiriu uma relação, assim próxima, você diz: "Vou entrevistar um sujeito desses... (risos) eu não vou consegui focar o que eu quero".

Eduardo - E ao mesmo tempo, uma das coisas que eu discuto lá, é que, as vezes é possível você fazer... você desejar fazer uma pesquisa tão distanciada assim, no caso da educação?

Paulo - Não você sempre... na verdade quando você... está na pesquisa, você esta produzindo o dado, as pessoas acham que você esta coletando um dado, não é verdade, você está produzindo e quando você produz, você coloca todas as tuas teorias em ação, eu ouvi um cara falando uma vez que quando você olha o seu objeto de estudo você já interpreta, não dá para separar interpretação de olhar, então vão as tuas teorias, vai aquilo que você pensa, se você pensar no positivismo clássico, isso é um absurdo, do ponto de vista do positivismo clássico isso é um absurdo, do ponto de vista da pesquisa qualitativa isso é aceitável.

Eduardo - Então a discussão que eu estou fazendo essa discussão, estou fazendo uma discussão muito profunda sobre metodologia, discutindo como fazer pesquisa dentro da escola, com todas essas tramitações. Eu estou me baseando em uma teoria que vem da etnografia, mas que vai além, que é a teoria da implicação, ela é uma teoria que diz que é impossível realmente você analisar o objeto sem se envolver com ele, então para não ficar falso você assume seu envolvimento, então você deixa claro, então você escreve muitas vezes em primeira pessoa.

Paulo - É. Deixa claro o teu olhar: "estou olhando a partir disso, daquilo", as pesquisas narrativas, ou auto-biográficas... e é uma briga. Um cara que faz muito isso, que é extremamente citado na educação é o Novoa... ele trabalha com isso. E há o outro lado, há pessoas que não consideram, acham que: "Como é que você pode fazer pesquisa com 2 sujeitos, com 1 sujeito? A questão interessante desse ponto de vista é o seguinte, tem uma piada muito interessante viu: "Isso depende muito da força do seu orientador" (risos!). Você entendeu? (risos!)

Eduardo - Isso é verdade! 
Paulo - O poder que ele tem é determinante de que linha você esta usando. Eu não estou usando a narrativa, eu fiz o seguinte, estou trabalhando com formação de professores à distância, então eu fiz algumas entrevistas preliminares, eu tenho lá 100 professores que fizeram esse curso à distância que nós demos, já está na $3^{\circ}$ edição, eu fiz as entrevistas e tive uma idéia das respostas que eles... aí eu não tenho que questionar, montei dois tipos, aí não apliquei, um deles é aquele formato líquert, que mede a atitude, e o outro é semi-estruturado. Então a idéia agora é aplicar o questionário ou um ou outro e depois entrevistar uns 15 sujeitos dessa mostra, mais profundamente, enfim e fazer um pouco de qualitativa e um pouco de... é... misturar um pouco isso, mas enfim, eu acho... penso exatamente como você, não há como... quando você está produzindo um dado, você não colocar o que você acredita.

Eduardo - Eu também vejo que isso é um elemento novo, que eu estou tentando discutir, que é o seguinte, sempre que se fez pesquisa em educação, se fez de fora da escola, eram os acadêmicos, então se você faz de dentro, você tem que mudar a metodologia, é um outro método que não aquele.

Paulo - Você vai encontrar, você já deve ter... num autor chamado Tardif.

Eduardo - Ah! Ta. Eu não o li mas é uma das leituras obrigatórias.

Paulo - Ele faz uma... tem um artigo dele sobre educação em que ele faz uma análise da pesquisa e ele começa a dizer que a partir da década de 1980/90, os acadêmicos começaram a se preocupar com os saberes dos professores, que os professores... não de quem está fora da escola. E aí propõe um conjunto de saberes que os professores têm, saber prático, saber da experiência e faz uma categorização em cima disso, e aí ele mostra que você tem que estudar a escola, a partir da escola, agora, como? Etnograficamente? só observando? Eu tive uma discussão... e quando você interfere? Como é que é isso?

Eduardo - E quando o professor esta na sala de aula? (risos!)

Paulo - É, quando você está na sala de aula você está interferindo?

Eduardo - E quando na sua pesquisa você também é objeto de estudo?

Paulo - É, a pesquisa participante, você está ali no contexto. Eu fiz o mestrado com pesquisa participante, enfim eu já recebi algumas críticas por causa disso: "Não... mas você intervém!", é lógico, e eu "vira e mexe"... e eu era o coordenador do projeto, então tudo isso estava junto.

Eduardo - Então beleza Paulo, é isso. Valeu!

Paulo - Ta bom, eu espero que tenha ajudado. Bom trabalho.

\section{EXTRA}

Paulo - ...a educação profissional técnica trabalhava por competências e habilidades, o ensino médio também tem essas diretrizes, e os professores 
começaram a compreender o que significava isso. Então o sistema de formação foi muito interessante, foram 3 anos e isso resultou em novos currículos, em todos os cursos os currículos foram refeitos. Os sujeitos vinham com... quando o professor pode decidir, quando ele tem poder, eu também pos... eu posso, não é. Então ele participa, eles vinham. Eu nunca escrevi sobre isso por que não era muito a minha área, mas foi a maior experiência que eu passei aqui, tanto é que eu fiquei muito conhecido, eu fui para Campinas, que estava mudando... estavam instalando cursos de educação profissional técnica e eu fui para... me acharam aqui no Alcina e eu fui para lá na acessória, e eu fui... acabei indo sabe aonde cara? No programa do Serginho Groissman (risos!), eu comecei a publicar algumas coisinhas por aí, na internet, a assessora dele me achou e eu fui participar de um programa, parece que de sábado de manhã chamado Ação.

Eduardo - Ah! Ta. Eu sei qual é.

Paulo - E eu fui lá falar dessa experiência de São Caetano, de como eu via a educação... eu já tinha parado de mexer com isso, foi há anos atrás. Então eu acho que é possível.

Eduardo - Então parece que era uma simples discussão de currículo, que na verdade você estava pensando em uma formação de professores.

Paulo - Formação de professores direto, por que o sujeito tem que pensar o seu currículo... ele tem que pensar o que ele vai fazer... Então nós determinamos os currículos, ações que a gente chamava... por que quando a situação das competências e habilidades invadiram o Brasil, muito através do Felipe Perrenault e outros autores, ele falava muito e outros falavam também em preparar situações de aprendizagem, essas situações de aprendizagem são aulas... e na educação profissional técnica isso entra muito, por que ela tem uma especificidade que é a prática, a prática é...

Eduardo - Fundamental.

Paulo - E os professores começaram a fazer isso, enfim eu cataloguei um conjunto... nós chegamos a fazer uma experiência, com o Guto, o dia que você encontrar com o Guto, ele subia no laboratório de ciências, de química e ele fazia um doce, acho que era um brigadeiro, e nesse doce ele fazia um cálculo, ele dava a contabilidade, então o sujeito tinha que calcular o peso do brigadeiro, dizer quanto ia de mão-de-obra, de gasto com muito e tem umas tabelas que eles fazem de quanto vale o material, quanto gasta, para calcular o preço do produto, a embalagem etc., então nós fizemos a seguinte experiência com os professores, alguns reclamaram de indisciplina, e eu disse o seguinte: "A indisciplina acontece, tem uns sujeitos aí que...", mas ela é diretamente relacionada à atividade que você dá, ao que ele se engata na atividade. Então nós fizemos assim, o Guto começou a atividade e ele saia da sala, do laboratório e a gente ficava por ali, nós estávamos em uns 8/10 professores, rapaz, foi muito interessante, eu deveria ter filmado para relatar isso depois, o envolvimento era tão grande, estávamos no laboratório, podia mexer em reagentes, diziam: "Vamos tirar reagentes?", eu falei: "Nós não vamos tirar nada, deixa do jeito que está!" e eles ficaram lá trabalhando por mais de 40 minutos, tocou o sinal de uma hora e eles continuaram lá fazendo, tal era o envolvimento na atividade, foi muito interessante. Então a gente fazia 
isso também, porque isso veio, quer dizer, eu encontrei não sei se veio, de uma corrente americana que eles falam do... não me lembro como é que chama... não é tutor... mas eles chamam de píer, píer alguma coisa, é o seguinte, eu passo alguns dias na tua sala de aula vendo o que você está fazendo, é um tipo de formação de professores, depois um outro sujeito faz uma aula e os professores assistem para poder... é um tipo de formação, e a gente tentou isso daí, ele preparou a aula...

Eduardo - E tem agora um da física que está com projeto desses, o Menezes, não sei se você conhece...

Paulo - Luiz Carlos Menezes. Eu conheço.

Eduardo - Ele está com um projeto desses de professor tutor. É um cara que vai ser pago pelo governo e vai estar na escola fazendo a ponte da escola, do professor com os alunos com a universidade. E está começando como projeto piloto.

Paulo - Então, nesse caso do Menezes... eu tive alguns contatos com ele porque ele escreveu as apostilas do Pueridomos e ele escreveu os referenciais curriculares de física para o MEC, para o ensino médio.

Eduardo - E ele participou também do ENEM, ele é um dos organizadores do ENEM.

Paulo - Exatamente, e alguns outros lá, e ele é da física.

Eduardo - Ele é um cara super disponível, eu já tive alguns contatos com ele, eu tenho um amigo que é da física, que faz mestrado no ensino de física ele tem contato.

Paulo - Ele tem bastante textos na área da educação, ele faz uma ponte interessante. Então essa experiência foi muito enriquecedora.

Eduardo - Imagino!

Paulo - Quer uma oportunidade, pega um professor daqui antigo, e fala : "Como é que foi? Como é que vocês fizeram? o que aconteceu? Eu tive um professor o Afonso, não sei se você conheceu.

Eduardo - Já ouvi falar, mas nunca conheci.

Paulo - Esse era problema, as vezes ele sentava, pegava uma cadeira assim, e lá ficava, ele gostava de reter aluno, e ele participou dessa experiência, e ele começou a desenvolver jogos, ele dava materiais, curso, parte técnica, ele começou a desenvolver um jogo em que o aluno ia jogando e aprendendo o processo de como você faz requisição de material, era um negócio enorme, você jogava com dados e cais em tal casa você tinha que relatar um negócio em relação aquilo, uma ferramenta muito interessante que ele desenvolveu. Então a partir de uma experiência de currículo os professores passaram a desenvolver ferramentas ou sei lá qualquer coisa para ser utilizada, por que se você... esse 
acho que é um dos motivos da formação de professores, porque se não os professores ficam muito ali no giz e na lousa, mas as vezes, nem é por que ele não quer, não é, ele não tem tempo para desenvolver.

Eduardo - Também não tem essa abertura, esse envolvimento, por que se fala muito do desenvolvimento do aluno, mas se fala tão pouco do desenvolvimento do professor com a escola, com o currículo, nem nada disso.

Paulo - É verdade. Se você... o professor está acostumado a dar a sua aula e...

Eduardo - Ir embora.

Paulo - Não se envolver nessas questões, ele teria que se envolver. O diretor dá o tom da escola. O diretor, com o discurso dele, ele dá o tom do discurso que os professores vão seguir mais ou menos a linha, então se o discurso dele dá a possibilidade do outro falar isso é interessante, mas é difícil, não são todos os diretores, porque quando você abre, você vai ouvir muitas coisas que você não quer ouvir, então os diretores preferem muitas vezes colocar... toda sala de aula tem um vídeo, toda sala de aula tem um... mas ninguém usa. Relacionamento com pessoas, é difícil, complicado, você tem que ouvir muitas vezes, eu ouvi tantas críticas, você engole, algumas você rebate, outras eu não rebatia, eu achava que o professor não estava preparado naquele momento. Então você segura para falar um pouco depois.

\section{PAUSA}

Eduardo - ... Paulo Freire acompanhando a gestão da... que até ainda se mantém um pouco na prefeitura de São Paulo, mas que com o tempo escreve menos, não é.

Paulo - É muito difícil. Uma coisa que eu vejo bastante é que o discurso não é maduro o suficiente para dizer, falar: "Eu não concordo com você, você me desculpe, mas...", isso é uma coisa madura, entre profissionais, e na escola, nem todo mundo quer ouvir, e muitas vezes o professor: "Ah! Eu vou fazer diferente? Sabe que não dá, por que os pais vão reclamar..."

Eduardo - Entra o elemento externo, não é.

Paulo - É. Os professores, Eduardo, isso eu aprendi na pesquisa, eles também sabem o que o diretor quer ouvir, as pessoas sabem, o professor sabe também 0 que você quer ouvir, esse é um olhar cuidadoso, você que está começando na pesquisa, você tem que ter... você vai conversar com um professor, ele vai te falar... você vai dando o tom da conversa, ele vai também... entendeu? Então eu percebo que falta maturidade nos discursos.

Eduardo - Os lugares estão postos muitas vezes, não é? Você assume aquele lugar institucional. E a fuga do professor no interior da escola tem essa função, ele assume aquele lugar institucional. Isso que às vezes me incomoda muito, porque eu vejo que aquele lugar que a instituição me coloca não é um lugar que eu quero, me incomoda aquele lugar, de não participar de não me envolver. Foi aquilo que eu falei no "help" aquela vez... 
Paulo - Lembro.

Eduardo - me incomoda no sentido de que eu vou para a sala de aula, volto, e qual que é a contribuição que eu dou além disso, não é?

Paulo - Eu entendi, e eu acho que isso seria um negócio... o que eu vejo as vezes é que os professores se recolhem, por que você está ali não é... é complicadíssimo... eu disse à você outro dia: "Nem sempre foi assim", já foi um efervescente de, mas o efervescente é uma coisa engraçada porque ele não morre, os professores estão ai, estão fazendo projetos, o que me surpreendeu muito, eu preciso falar para ela, foi a Juliana, no primeiro dia que ela chegou aqui, eu achei que ela fosse ter um "treco", no primeiro dia que eu conversei com ela, que comecei a explicar, ela não tinha a mínima experiência, aí eu subi com ela na sala de aula, apresentei os... ela estava nervosa, aquele período inicial que ela fez o possível para sobreviver enquanto professora, e eu vejo ela apresentando trabalho, fez um trabalho com vocês.

Eduardo - Mas você sabe... eu vou te dizer uma coisa, sabe onde eu vejo, onde se deu a formação dela, e uma formação as vezes que a gente não dá conta, que é a formação da sala dos professores, que é falar: "A Denise fala isso, a Ana Maria fala isso", é essa questão também de tradições, que tradições os professores mais antigos passam para a gente? Eu posso falar da minha experiência também a tradição que eles deixam para a gente: "Não faz isso, porque isso não dá certo, faz aquilo..." você sente uma segurança de falar com eles.

Paulo - Vocês se juntaram, eu vejo isso também, com um grupo que pensa, que quer ir embora, que cresceu, que tem alguns grupos na sala dos professores que talvez você recebesse uma outra formação - "Prá que que vocês está fazendo isso rapaz",

\section{Eduardo - São essas formações}

Paulo -Isso, tem um grupo preocupado, tem um grupo que... e ela se juntou ali e hoje ela está pronta. Eu acho que tá pronta, no sentido que ela melhorou, apresentou trabalho, nova, um ano de caso, enquanto muitos velhos tavam ali, pegar no microfone não é fácil.. É isso aí.

Eduardo - Obrigado. 


\section{Questionário aplicado na EME PROFa Alcina Dantas Feijão.}

O seguinte questionário faz parte do trabalho de pesquisa para o desenvolvimento da Dissertação de Mestrado - Escolar e saber: a pesquisa na educação básica. As respostas aqui apresentadas serão utilizadas apenas com fim acadêmico e não é necessário se identificar. Sintam-se a vontade para responder. Não existem limites de linhas para cada resposta.

1) Há quantos anos está na carreira docente? Há quantos atua como docente na EME Profa. Alcina Dantas Feijão

2) Escreva um pouco sobre sua formação inicial e o início de sua carreira como professor (curso que fez, onde se formou, por que escolheu esta profissão, dificuldades iniciais).

3) Qual é a sua concepção de formação continuada?

4) Como a Escola contribui para a sua formação continuada, para ao aperfeiçoamento de suas práticas pedagógicas?

5) Quais as principais diferenças existentes entre o Alcina e outras escolas nas quais você já lecionou?

6) Como a realidade da cidade influencia nas questões relacionadas ao Alcina, principalmente no que diz respeito a suas práticas pedagógicas?

7) Quais os principais problemas que tem enfrentado em seu trabalho docente (no Alcina e em outras escolas) nos últimos anos?

8) Como você definiria um professor-pesquisador?

9) Como a pesquisa poderia contribuir em sua formação continuada? 